Universidade de São Paulo

Faculdade de Filosofia, Letras e Ciências Humanas

Departamento de História

Programa de Pós-Graduação em História Social

Roberta Julien Miranda

\title{
LE VIANDIER DE TAILLEVENT: O CONSUMO SUNTUÁRIO DE CARNE PELO GRUPO NOBILIÁRQUICO NOS SÉCULOS XIII E XIV NA FRANÇA E SEU CONTEXTO HISTÓRICO
}




\section{Roberta Julien Miranda}

\section{LE VIANDIER DE TAILLEVENT: O CONSUMO SUNTUÁRIO DE CARNE PELO GRUPO NOBILIÁRQUICO NOS SÉCULOS XIII E XIV NA FRANÇA E SEU CONTEXTO HISTÓRICO}

Dissertação apresentada ao Programa de Pós-Graduação em História Social do Departamento de História da Faculdade de Filosofia, Letras e Ciências Humanas da Universidade de São Paulo, para obtenção do título de Mestre em História.

Área de concentração: História Social

Orientador: Prof. Dr. Henrique Soares Carneiro 
Autorizo a reprodução e divulgação total ou parcial deste trabalho, por qualquer meio convencional ou eletrônico, para fins de estudo e pesquisa, desde que citada a fonte.

MIRANDA, Roberta Julien

Le Viandier de Taillevent: o consumo suntuário de carne pelo grupo nobiliárquico nos séculos XIII e XIV na França e seu contexto histórico./Roberta Julien Miranda; Orientador: Professor Doutor Henrique Soares Carneiro - São Paulo, 2013. 204 fls. 
Dissertação (Mestrado - Programa de Pós-graduação em História, Área de concentração: História Social) - Faculdade de Filosofia, Letras e Ciências Humanas da Universidade de São Paulo

Nome: MIRANDA, Roberta Julien

Título: Le Viandier de Taillevent: o consumo suntuário de carne pelo grupo nobiliárquico nos séculos XIII e XIV na França e seu contexto histórico XXI.

Dissertação apresentada ao Programa de História Social, do Departamento de História da Faculdade de Filosofia, Letras e Ciências Humanas da Universidade de São Paulo, para obtenção do título de Mestre em História.

Aprovada em:

Banca Examinadora

Prof. Dr. Instituição:

Julgamento: Assinatura:

Prof. Dr. Instituição:

Julgamento: Assinatura:

Prof. Dr. Instituição:

Julgamento: Assinatura: 
À minha mãe 


\section{AGRADECIMENTOS}

Agradeço em primeiro lugar às pessoas sem as quais esse trabalho não seria realizado: meus pais, Sandra Julien Miranda e Antonio Cesar Macedo de Miranda, e meu orientador, Henrique Soares Carneiro. Em seguida, aos professores Ana Paula Tavares Magalhães, Carlos Roberto Figueiredo Nogueira, Eduardo Henrik Aubert, Flavio de Campos, Francisco Alambert, Maria Cristina Pereira e Rodrigo Ricupero, e também ao meu irmão Diogo Julien Miranda e aos amigos Daniella Lopes, Giuliana Aggiunti, Marinalva Lima, Silvia Lobo e Wilson Goularte. Agradeço finalmente a todos que, direta ou indiretamente, contribuíram para a elaboração desta dissertação, os quais deixo de nomear, sob pena de que eventual omissão resulte em injustiça. 
MIRANDA, Roberta Julien. Le Viandier de Taillevent: o consumo suntuário de carne pelo grupo nobiliárquico nos séculos XIII e XIV na França e seu contexto histórico XXI. 2013. 204 f. Dissertação (Mestrado em História Social) - Faculdade de Filosofia, Letras e Ciências Humanas, Universidade de São Paulo, São Paulo, 2013.

Este trabalho consiste em um estudo do consumo de carne pelo grupo nobiliárquico nos séculos XIII e XIV, na França, e seu significado cultural, baseado na análise do tratado de cozinha Le Viandier de Taillevent. A pesquisa teve início com a tradução para a língua portuguesa do Le Viandier de Taillevent e a catalogação das receitas e respectivos ingredientes. Em seguida, foram realizadas comparações analógicas com outro tratado de cozinha do mesmo período, Le Ménagier de Paris, e com Le Fabliau de Cocagne, documento francês do século XIII. O desenvolvimento da dissertação tem como ponto de apoio a bibliografia especializada em alimentação na Idade Média, a partir da qual o tratado Le Viandier de Taillevent é contextualizado. São apresentadas análises do consumo de carne e sua simbologia no contexto social, em articulação com o exercício do poder, a economia, a religião, a dietética e a culinária.

Palavras-chave: alimentação, carne, Cocanha, Le Ménagier de Paris, Le Viandier de Taillevent. 
MIRANDA, Roberta Julien. Le Viandier de Taillevent: the sumptuary consumption of meat by the nobiliary group in France, in the $13^{\text {th }}$ and $14^{\text {th }}$ Centuries and its historical context. XXI. 2013. 204 f. Dissertação (Mestrado em História Social) - Faculdade de Filosofia, Letras e Ciências Humanas, Universidade de São Paulo, São Paulo, 2013.

This dissertation consists of the study of the meat consumption by the nobility group during the $13^{\text {th }}$ and $14^{\text {th }}$ centuries in France and its cultural meaning, based on the analysis of the culinary treatise Le Viandier de Taillevent. The research work began with the translation of the referred document to Portuguese and cataloguing of recipes and respective ingredients. Subsequently, analogical comparisons were made between Le Viandier de Taillevent and two further French culinary documents from the same period, Le Fabliau de Cocagne and the treatise Le Ménagier de Paris. The development is supported by a specialized bibliography on nourishment habits in the Middle Ages, from which Le Viandier de Taillevent was put into perspective. The analysis of the consumption of meat and its symbolic meaning for the social context are presented and related to the exercise of power, economy, religion, and dietetics and cooking.

Key words: Cocagne, Le Ménagier de Paris, Le Viandier de Taillevent, meat, nourishment. 


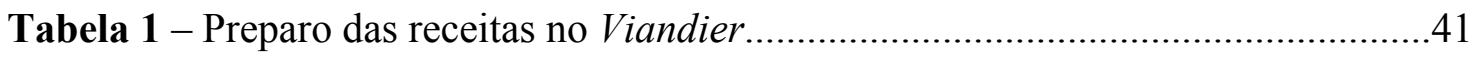

Tabela 2 - Receitas que utilizam carne de porco no Viandier .....................................47

Tabela 3 - Receitas que utilizam bacon no Viandier...............................................48

Tabela 4 - Receitas que utilizam carne de caça no Viandier ..........................................52

Tabela 5 - Receitas que utilizam carne de criação no Viandier .....................................55

Tabela 6 - Receitas específicas de viandas para Quaresma no Viandier .......................67

Tabela 7 - Receitas específicas de peixe para Quaresma no Viandier ..........................68

Tabela 8 - Receitas que não apresentam carne no Viandier........................................73

Tabela 9 - Receitas que apresentam carne no Viandier ..........................................87

Tabela 10 - Receitas de carne com especificação de molho no Viandier.....................95

Tabela 11 - Receitas de molho no Viandier...............................................................97

Tabela 12 - Especiarias mais frequentes no Viandier .................................................99

Tabela 13 - Receitas que apresentam açúcar no Viandier........................................103

Tabela 14 - Receitas de entremezes constantes do Viandier.......................................105

Tabela 15 - Entremezes artísticos constantes do Viandier ..........................................106

Tabela 16 - Receitas de ave constantes do Viandier ...................................................124

Tabela 17 - Receitas de carne comuns ao Ménagier e ao Viandier.............................143

Tabela 18 - Receitas de carne comuns ao Ménagier e ao VAT ....................................144

Tabela 19 - Receitas de molhos para carne comuns ao Ménagier e ao Viandier..........144 


\section{INTRODUÇÃO}

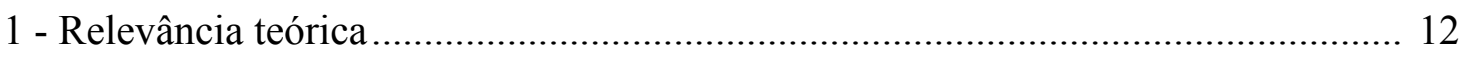

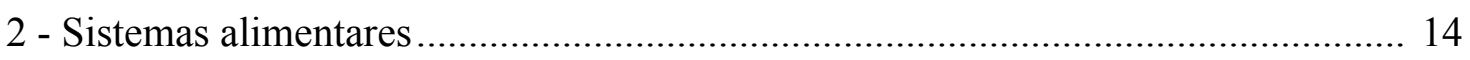

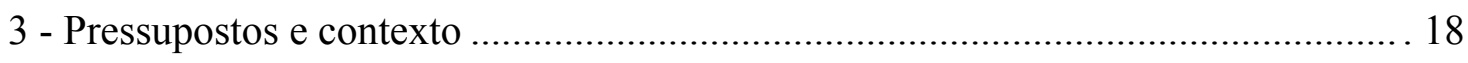

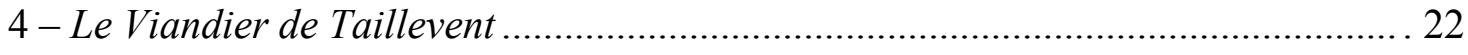

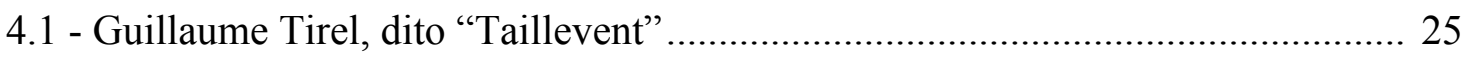

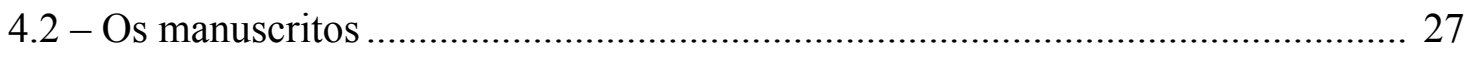

\section{CAPÍTULO I}

A CARNE E O OCIDENTE MEDIEVAL CRISTÃO

1.1 - A carne no Ocidente Antigo e as mudanças medievais .................................. 34

1.2 - Os tipos de carne e a relevância social ........................................................ 40

1.2 .1 - A importância social........................................................................... 40

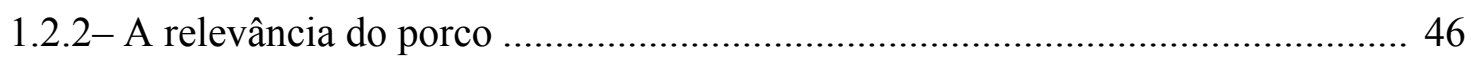

1.3 - A produção e a circulação de carne ................................................................ 50

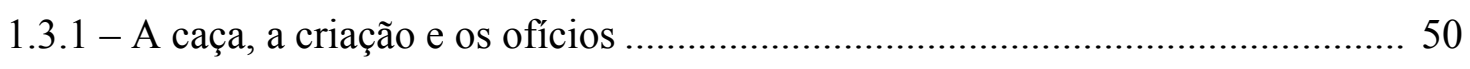

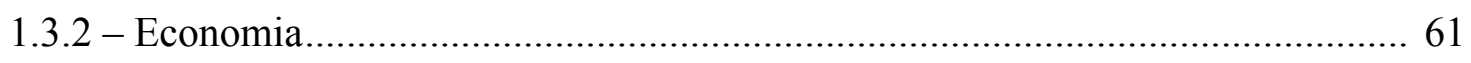

\section{CAPÍTULO II}

TENSÕES E REPRESENTAÇÕES

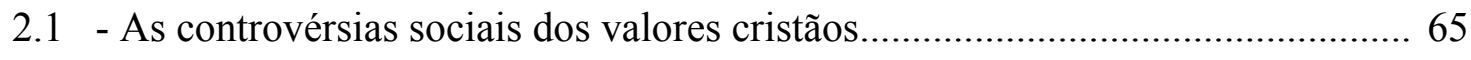




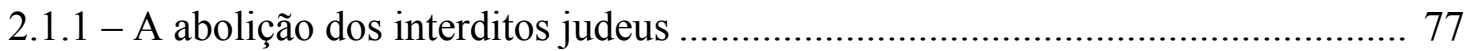

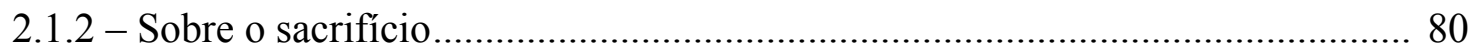

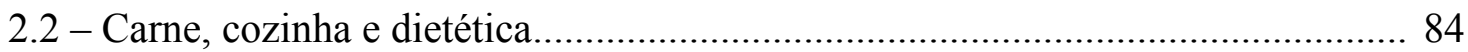

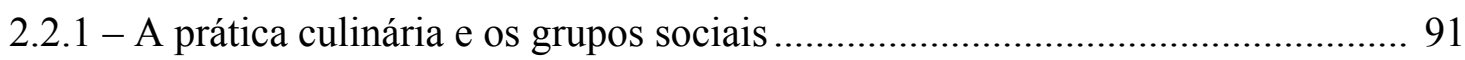

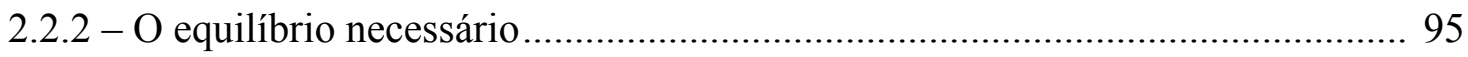

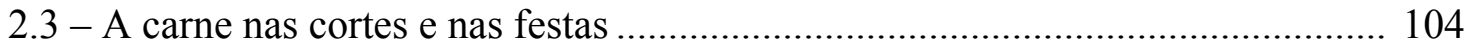

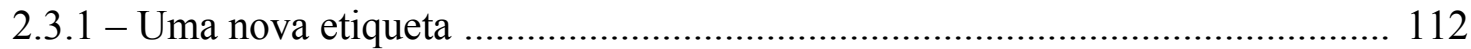

\section{CAPÍTULO III}

O VIANDIER, O MÉNAGIER E O FABLIAU DE COCAGNE

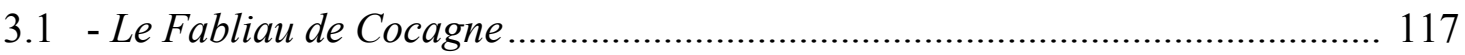

3.1.1 - Conflitos, permanências e ausências .......................................................... 123

3.1.2 - Várias faces de uma utopia: versões posteriores da Cocanha ...................... 128

3.2 - Le Ménagier de Paris ................................................................................... 132

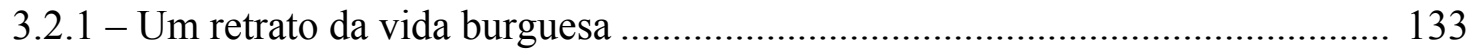

3.2.2 - O burguês desconhecido e uma esposa perfeita ........................................ 136

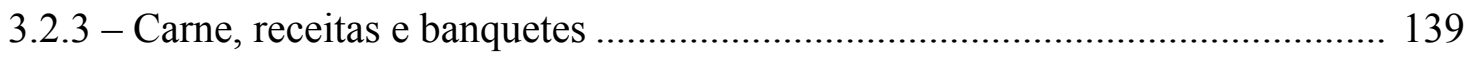

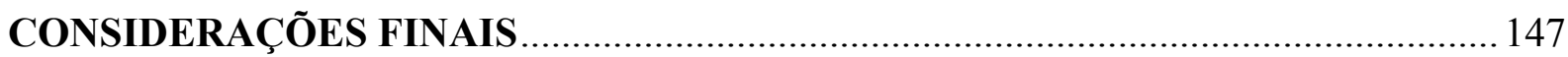

TRADUDUÇÃO - LE VIANDIER DE TAILLEVENT ............................................. 151

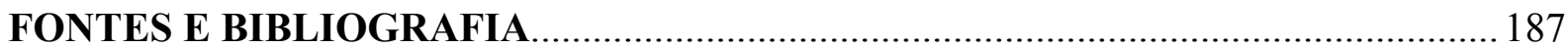




\section{INTRODUÇÃO}

\section{Relevância teórica}

Além de a alimentação ser primordial para a sobrevivência do homem, o alimento também é considerado uma fonte de prazer. As relações de poder e as desigualdades sociais condicionam-se a uma história complexa que articula esses dois aspectos da alimentação ${ }^{1}$.

A alimentação é o aspecto da cultura material subjacente a toda atividade humana. Além de ser uma necessidade biológica básica, é também um sistema simbólico complexo, com significados sociais, políticos e religiosos. Os apetites expressam desejos que se materializam em hábitos, costumes e rituais, os quais estão diretamente ligados ao poder. A história da alimentação refere-se não apenas à história dos alimentos, mas à sua distribuição, preparo e consumo. A pesquisa historiográfica deve esclarecer o que foi comido, quando, onde e, principalmente, por qual razão e de que maneira ${ }^{2}$, enfocando a demanda por comida, os mercados, os preços e as formas de conhecer, adquirir, obter, estocar e transportar alimentos, bem como as técnicas de preparação, as formas de consumo, o ambiente sociocultural e as avaliações individuais e coletivas, além dos conteúdos nutritivos e das consequências para a saúde ${ }^{3}$.

A domesticação de animais foi importante desde as primeiras civilizações, na medida em que serviram como alimento, transporte, tração, caça e companhia, além de terem fomentado a crença nas encarnações do sagrado, e incitado a prática de gulas, tabus e complexas regulamentações rituais ${ }^{4}$.

Este trabalho se propõe a traduzir para o português o tratado de cozinha intitulado Le Viandier de Taillevent, bem como tecer uma análise a respeito do papel da

\footnotetext{
${ }^{1}$ MONTANARI, Massimo. A fome e a abundância: história da alimentação na Europa. Tradução Andréa Doré. São Paulo: Edusc, 2003. p. 11.

${ }^{2}$ CARNEIRO, Henrique. Comida e sociedade: uma história da alimentação. Rio de Janeiro: Editora Campus, 2003, p 1-2.

3 TEUTEBERG, Hans. European food history: a research review. Londres: Leicester University Press, 1992 , p. 9.

${ }^{4}$ CARNEIRO, op. cit, p.66.
} 
carne e seu significado no contexto histórico dos séculos XIII e XIV, buscando compreender o papel simbólico que tal consumo suntuário carregava.

Os livros de cozinha, cujas compilações iniciam-se no século XIV, tendo atingido uma produção crescente até o final do século $X V$, parecem ser a fonte historiográfica mais vantajosa para a compreensão da alimentação medieval, ainda que sua análise demande algumas precauções. Obras literárias raramente descrevem a composição das refeições, mesmo com a valorização dos temas culinários da veia realista da canção de gesta e do romance cortês, a partir do século XII, principalmente na corte dos plantagenetas ${ }^{5}$. Os vitrais, afrescos e iluminuras podem esclarecer rituais alimentares, mas dificilmente são úteis para identificação de um produto servido. Quando muito se pode identificar uma ave, mas não sua espécie. E, infelizmente, os documentos contábeis medievais não apresentam, em grande parte, os registros diários das despesas de cozinha, embora muitas vezes a organização de festas excepcionais ocasionasse a abertura de uma rubrica específica nas contas de um palácio, o que informa o custo e os ingredientes de um banquete ${ }^{6}$.

\footnotetext{
${ }^{5}$ A dinastia Plantagenete ou Angevina era originária do Condado de Anjou (França) e chegou ao poder através do casamento do Conde de Anjou com a herdeira de Henrique I, Matilde da Inglaterra. O primeiro rei plantageneta foi Henrique II. A dinastia durou de 1154 a 1399 e teve fim com a Guerra das Duas Rosas. Os oito reis ingleses plantagenetas enfrentaram sempre o "fantasma" que pairava sobre a legitimidade da dinastia.

${ }^{6}$ LAURIOUX, Bruno. Cozinhas medievais. In: FLANDRIN, Jean Louis; MONTANARI, Massimo. (Org.). História da alimentação. Tradução Luciano Vieira Machado; Guilherme J. F. Teixeira. São Paulo: Estação Liberdade, 1998, p. 447-465.
} 


\section{Sistemas alimentares}

Para a cultura grega e romana da antiguidade o espaço inculto era a antítese da civilização. A floresta representava a marginalidade e apenas os excluídos e desviados recorriam a ela em busca de alimentação. A única forma de utilização dos recursos naturais a que os escritos gregos e latinos se referiam com alguma simpatia era o pastoreio de ovinos.

A ameaça constante de fome nos séculos V e VI levou a uma diversificação na alimentação do homem europeu. Tanto a situação demográfica quanto a ambiental possibilitaram esse tipo de solução, pois a população era escassa e o território desabitado. Mas a exploração do saltus, do espaço não cultivado, exigia a superação de preconceitos, o que aconteceu progressivamente. Atenuou-se o quadro político representado pelo império romano e começou a delinear-se uma nova ordem institucional, política e cultural. Pela primeira vez, um modelo produtivo e cultural conseguiu aproximar essas escolhas tão opostas ${ }^{7}$.

A cultura e os valores germânicos foram difundidos com sua expansão política e social. Os espaços incultos passaram a ser considerados espaços a serem usados e não um limite à atividade produtiva. Assim como os campos eram medidos em grãos, as vinhas em vinho e os prados em feno, nos séculos VII e VIII as dimensões dos bosques passaram a ser calculadas com base no número de porcos que seus carvalhos, bolotas e faias poderiam alimentar na Inglaterra, França, Alemanha e norte da Itália ${ }^{8}$.

O sistema agro-silvo-pastoril que se estabelecera durante a Alta Idade Média foi progressivamente abalado a partir do século XI. As culturas foram estendidas, em detrimento das terras incultas. Florestas inteiras foram derrubadas e delineou-se uma época em que "sem agricultura não era possível sobreviver"9.

A expansão das culturas, a restrição ao uso das florestas, a multiplicação dos mercados e a comunicação com os citadinos tiveram consequências consideráveis na alimentação. O consumo de alimentos de origem vegetal, em detrimento da carne, predominou entre as camadas sociais mais baixas e o regime alimentar perdeu muito da variedade que o caracterizara anteriormente. $\mathrm{O}$ pão e o vinho suplantaram os demais

\footnotetext{
${ }^{7}$ MONTANARI, Massimo. A fome e a abundância: história da alimentação na Europa. Tradução Andréa Doré. São Paulo: Edusc, 2003, p. 16-17.

${ }^{8}$ Ibidem, p. 25.

${ }^{9}$ Idem, 1998, p. 382-386.
} 
alimentos, que passaram à condição de complementares. Sua falta era intolerável, principalmente nas cidades. A coleta e a caça deixaram de ser recursos alimentares comuns e se tornaram marginais, reservadas à nobreza (caça) e aos muito pobres (coleta). Cada classe social utilizou uma parte desigual dos recursos agrários, silvícolas e pastoris e lhes atribuiu diferentes valores, combinando-os à sua maneira para constituir seu subsistema alimentar. A escolha dos alimentos era um forte elemento de identidade coletiva.

A carne era um dos principais elementos do modelo real e nobiliárquico, junto com o pão branco de trigo e o vinho. Em seguida, vinham ovos e queijo, os quais eram combinados com a carne em dias normais e alternados com peixe em dias de penitência. Já os legumes eram secundários ${ }^{10}$. As aves, por sua vez, eram as carnes mais valorizadas. As principais espécies de aves de criação eram galinhas, pombos, patos, gansos, galinhas-d'angola, pavões e cisnes ${ }^{11}$.

O regime alimentar do clero caracterizou-se pelo relaxamento crescente do respeito à regra monástica e por uma lenta secularização. Os monastérios inspiraram-se no modelo camponês, como exemplo de desapego e humildade. Mas o crescimento econômico modificou o funcionamento das abadias, cuja renda aumentou de forma extraordinária e provocou, no século XIII, uma queda dos princípios ascéticos e da frugalidade inicial. A carne foi incluída na dieta de ordens religiosas, embora com restrições. Para o clero secular, que aceitava as normas sociais do mundo, o consumo de carne não sofria restrição, a não ser por ocasião dos jejuns ${ }^{12}$. Mas mesmo alguns monastérios, como Cluny, se especializaram na criação de animais, visando o comércio não só da carne, mas também do couro.

$\mathrm{Na}$ alimentação dos camponeses as sopas e guisados, acompanhados de pão e vinho, constituíam a principal refeição. O regime caracterizou-se, em geral, pela autossuficiência e só se comprava o que não era possível produzir. Se os senhores se interessavam por algum tipo de alimento, este passava a ser considerado artigo de luxo e, portanto, era sempre vendido ou reservado para ocasiões especiais. O pão era comido em todas as refeições: um pão escuro, feito de cereais secundários (cevada, centeio ou

\footnotetext{
${ }^{10}$ RIERA-MELIS, Antoni. Sociedade feudal e alimentação (séculos XII e XIII). In: FLANDRIN, Jean Louis; MONTANARI, Massimo. (Org.). História da alimentação. Tradução Luciano Vieira Machado; Guilherme J. F. Teixeira. São Paulo: Estação Liberdade, 1998, p. 387-408.

11 DELORT, Robert. Animais. Tradução Vivian Coutinho de Almeida. In: LE GOFF, Jacques; SCHMITT, Jean-Claude. (Org.). Dicionário temático do Ocidente Medieval. São Paulo: Edusc, v. 1, 2006, p.5 7-67.

${ }^{12}$ RIERA-MELIS, op. cit, p. 387 et seq.
} 
espelta). A cor do pão simbolizava a condição social. A proliferação de moinhos indica que os cereais se destinavam em grande parte à panificação, hábito incentivado pelos senhores, tendo em vista a questão da rentabilidade. Com relação à carne, esta provinha do gado miúdo, principalmente de porcos, que tinham um papel importante na alimentação camponesa. Os ovos e as aves só eram consumidos em ocasiões festivas ou em casos de doenças, devido à demanda senhorial. Nesse contexto, é necessário destacar a diminuição da caça com o progressivo desaparecimento das florestas. No que diz respeito aos legumes, estes eram muito consumidos devido ao cultivo em hortas familiares (por mulheres, crianças e velhos) e consistiam a principal combinação com cereais $^{13}$. A caça não desapareceu de forma completa da mesa dos camponeses, da mesma maneira que sua abundância no cardápio da nobreza teve mais um sentido simbólico e metafórico do que real. A maior parte da carne que os nobres consumiam, ao contrário do que se imagina, provinha de criação. Esse dado é claramente perceptível na leitura das receitas do Viandier.

A carne fresca era privilégio das mesas senhoriais, principalmente a de caça. As aves domésticas, tais como galinhas, gansos e patos, eram consumidas frescas pelos camponeses, mas apenas em dias de festa. Estes contavam com a carne de porco ou ovelha conservada para garantir as provisões ${ }^{14}$. Mesmo carnes silvestres como de cervo ou javali eram salgadas ou defumadas ${ }^{15}$.

Importante é que mesmo com a retração do sistema agro-silvo-pastoril, em alguns momentos de crise, a criação camponesa de porcos aumentou, talvez devido à piora das condições alimentares e uma consequente tentativa de buscar alternativas.

A oposição entre os modelos rural e o citadino de consumo alimentar foi relevante na segunda metade da Idade Média. Tratou-se de uma oposição entre a economia de subsistência e a de mercado, entre a preparação doméstica e o recurso aos ofícios especializados ${ }^{16}$. De maneira geral, mesmo as pessoas mais pobres comiam mais carne na cidade do que no campo. A cidade tinha no comércio de carnes frescas uma de suas características mais marcantes, em oposição às carnes salgadas consumidas pelos camponeses. Com o tempo, surgiu nas cidades um desejo por novidades que contrastava

\footnotetext{
${ }^{13}$ RIERA-MELIS, Antoni. Sociedade feudal e alimentação (séculos XII e XIII). In: FLANDRIN, Jean Louis; MONTANARI, Massimo. (Org.). História da alimentação. Tradução Luciano Vieira Machado; Guilherme J. F. Teixeira. São Paulo: Estação Liberdade, 1998, p. 387.

${ }^{13}$ Ibidem, p. 387-408 et seq.

${ }^{14}$ No norte era costume conservar até mesmo a carne de boi, búfalo ou cavalo.

15 MONTANARI, Massimo. A fome e a abundância: história da alimentação na Europa. Tradução Andréa Doré. Edusc: São Paulo, 2003, p. 48-49.

${ }^{16}$ Idem, 1998, p. 382-386.
} 
com a cozinha tradicional do porco, um desejo de distinção que levou à busca de novos alimentos e modelos de consumo. Nesse contexto, o carneiro era a carne preferida, principalmente pelos mercadores ${ }^{17}$. Em geral, a população urbana era beneficiada não só pela possibilidade e variedade que o mercado apresentava, como também pelas regras de aprovisionamento, que procuravam, nem sempre com sucesso, garantir o abastecimento. No entanto, em situações de crise, a cidade sofria mais do que o campo, não só com os preços muito elevados, mas, também, em alguns momentos, com o desaparecimento de alimentos dos mercados e a consequente impossibilidade de consegui-los de uma outra maneira ${ }^{18}$.

\footnotetext{
${ }^{17}$ RIERA-MELIS, Antoni. Sociedade feudal e alimentação (séculos XII e XIII). In: FLANDRIN, Jean Louis; MONTANARI, Massimo. (Org.). História da Alimentação. Tradução Luciano Vieira Machado; Guilherme J. F. Teixeira. São Paulo: Estação Liberdade, 1998, p. 387-408.

${ }^{18}$ MONTANARI, Massimo. Alimentação. Tradução Vivian Coutinho de Almeida. In: LE GOFF, Jacques; SCHMITT, Jean-Claude. (Org.). Dicionário temático do Ocidente Medieval. São Paulo: Edusc, v. 1, 2006, p. 35-45.
} 


\section{Pressupostos e contexto}

Na Idade Média, a alimentação correspondia a uma expressão material de um estilo de vida e uma dada condição social que devia ser manifestada da forma mais clara possível $^{19}$. Em seus últimos séculos, essa problemática apareceu de maneira mais acentuada como uma forma eficiente de corroborar com uma determinada ordem social hierárquica. A maneira de comer correspondia a um padrão de relações humanas e sentimentos, numa estrutura social claramente definida ${ }^{20}$.

O crescimento das cidades e do mercado, no final da Idade Média, não só acrescentou um novo grupo ao cenário social (o dos burgueses), como provocou profundas mudanças na identidade desses grupos, gerando tensões sociais que culminaram nos conflitos e enfrentamentos do século XIV, entre camponeses e nobres, nobres e nobres, nobres e burgueses, alta burguesia e baixas camadas urbanas. Os camponeses, oprimidos pela servidão e altas taxas, passaram a enxergar os nobres cada vez menos como seus protetores. A própria aristocracia, antes um grupo coeso, dividiuse em inúmeros subgrupos particulares, alguns dos quais se aproximaram da alta burguesia mercantil. E os grupos citadinos subdividiram-se em camadas altas, médias e baixas, de interesses conflitantes não só com os da aristocracia, mas também conflitantes entre si. Esses grupos e subgrupos aproximaram-se e afastaram-se movidos não só pela identidade, mas pelos interesses e benefícios que poderiam obter com alianças diversas. Nesse contexto, a alimentação, como mecanismo de distinção, adquiriu regras tão mais rígidas quanto mais ameaçadas as identidades. Ao mesmo tempo, a mobilidade e o contato fizeram dessas fronteiras zonas permeáveis e de trocas. O desejo de distinção nem sempre correspondeu a uma distinção de fato.

Na baixa Idade Média, o acesso aos bens comunitários para criação de animais em semiliberdade foi restringido, o que prejudicou principalmente as famílias pobres. Mas o consumo de carne ainda foi significativo, embora menor que nos séculos

\footnotetext{
${ }^{19}$ MONTANARI, Massimo. Estruturas de produção e sistemas alimentares. In: FLANDRIN, Jean Louis; MONTANARI, Massimo. (Org.). História da alimentação. Tradução Luciano Vieira Machado; Guilherme J. F. Teixeira. São Paulo: Estação Liberdade, 1998, p. 292-309.

${ }^{20}$ ELIAS, Norbert. O processo civilizador. Rio de Janeiro: Jorge Zahar, 1994, passim.
} 
anteriores. Os camponeses criavam aves e principalmente porcos, melhorando com isto a própria alimentação ${ }^{21}$.

A época do Imperador Frederico II, no século XIII, é referida por Ricobalto de Ferrara, meio século depois, como uma época de pobreza, em que o povo só podia consumir carne fresca três vezes por semana ${ }^{22}$.

A caça tornou-se privilégio da nobreza a partir do século XI, embora não se possa afirmar que tenha deixado de fazer parte da mesa camponesa. Mas essa interdição durou vários séculos e a atividade se tornou uma regalia símbolo de um grupo ${ }^{23}$.

$\mathrm{Na}$ Alta Idade Média, a produção de alimentos baseou-se no sistema agro-silvopastoril, tendo predominado um modelo "misto" de regime alimentar, que se apoiava na utilização de cereais e legumes, mas também de peixe e carne - alimentos importantes e indispensáveis para assegurar a sobrevivência da maioria e/ou o prazer da elite. Em tempos normais, o uso do território e os direitos de caça, pesca e pastagem eram exercidos por todos e as diferenças sociais no que se refere ao comportamento alimentar diziam mais respeito à quantidade do que à qualidade dos alimentos. Mesmo a noção de escassez dizia respeito não só a uma crise na agricultura, mas possuia um significado multiforme (crise nos rios ou florestas). Posteriormente, adquiriu o sentido estrito de falta de cereais ${ }^{24}$. No século VIII, uma multidão faminta que pedia esmola à porta de um mosteiro foi alimentada com carne ovina e bovina até a colheita seguinte, conta a Vita de São Bento de Aniane (480-547). Situação impensável três séculos mais tarde ${ }^{25}$.

A partir do ano 1000, a explosão demográfica colocou em crise o sistema de produção agrícola. A agricultura foi desenvolvida em detrimento das atividades silvopastoris, o que levou ao aumento das áreas cultivadas e, consequentemente, à diminuição das florestas e pastagens. Já a exploração dos recursos silvestres foi reservada cada vez mais aos grupos dominantes. Segundo Mássimo Montanari, a regulamentação e até abolição dos direitos de exploração dos espaços incultos é talvez o mais importante acontecimento da história alimentar das camadas subalternas. Ela provocou uma tendência à diferenciação social dos regimes alimentares. A partir daí, a

\footnotetext{
${ }^{21}$ CORTONESI, Alfio. Cultura de subsistência e mercado: a alimentação rural e urbana na baixa Idade Média. In: FLANDRIN, Jean Louis; MONTANARI, Massimo. (Org.). História da alimentação. Tradução Luciano Vieira Machado; Guilherme J. F. Teixeira. São Paulo: Estação Liberdade, 1998, p. 409-421.

${ }^{22}$ MONTANARI, Massimo. A fome e a abundância: história da alimentação na Europa. Tradução Andréa Doré. São Paulo: Edusc, 2003, p. 76.

${ }^{23}$ Idem, 1998, p. 282-291.

${ }^{24}$ Idem, 2006, p. 35-45

${ }^{25}$ Idem, 2003, p. 68-69.
} 
alimentação das classes inferiores passou a basear-se essencialmente em produtos vegetais e o consumo de carne tornou-se sinal de prestígio ${ }^{26}$.

Braudel já expressara a necessidade do reconhecimento do papel da geografia e da natureza no que tange ao consumo e ao mercado, bem como a importância da investigação e do estudo minucioso da ocupação dos espaços, em um processo contínuo de conquista e expansão. É necessário tomarmos sempre em conta as imposições colocadas por estes espaços e as alternativas encontradas. Sua perspectiva histórica de longa duração rompe com a dicotomia sociedade-natureza. Segundo a percepção do autor, a agricultura atua sempre sobre a natureza e a economia a vê como um recurso a ser constantemente explorado ${ }^{27}$.

Robert Fossier aborda o fenômeno sob outro ângulo e traz à tona a singular importância da dupla face da Europa Medieval, chamando atenção para o bosc, saltus, outfield inculto que pode ser a floresta, mas também as charnecas, as savanas, as turfeiras e as pastagens montanhosas, em oposição à terra dominada: ager, plain, infield. Segundo o autor, a economia medieval teria sido sempre conjunta e complementar entre esses dois domínios naturais, com um reajuste contínuo de avanço e recuo. A interrupção desse ciclo constante implicaria no próprio fim da Idade Média. E se em determinado momento o impulso demográfico realmente levou à ampliação da zona de cultivo à custa do saltus, as fontes são por demais imprecisas para que se possa avaliar, senão de forma aproximada, qual foi a verdadeira dimensão da diminuição do outfield. Não se conhece exatamente a amplitude desse desmatamento, a não ser através da análise de contratos sobre dízimo e de direitos sobre os bosques. No entanto, é inquestionável que o saltus recuou, e com isso diminuiu a disponibilidade da coleta, da caça e da criação ${ }^{28}$.

Da mesma maneira, Alain Guerreau reconhece a importância do recuo do saltus na Baixa Idade Média e seu impacto sobre a alimentação das camadas sociais inferiores, o que teria feito aumentar ainda mais a coação material do sistema feudal ${ }^{29}$.

\footnotetext{
26 MONTANARI, Massimo. Alimentação. Tradução Vivian Coutinho de Almeida. In: LE GOFF, Jacques; SCHMITT, Jean-Claude. (Org.). Dicionário temático do Ocidente Medieval. São Paulo: Edusc, v. 1, 2006, p. 35-45.

${ }^{27}$ BRAUDEL, Fernand. História e ciências sociais. Tradução Carlos Braga; Inácia Canelas. São Paulo: Martins Fontes, 1972, passim.

${ }^{28}$ FOSSIER, Robert. Terra. Tradução Vivian Coutinho de Almeida. In: LE GOFF, Jacques; SCHMITT, Jean-Claude. (Org.). Dicionário temático do Ocidente Medieval. São Paulo: Edusc, v. 2, 2006, p. 543557.

${ }^{29}$ GUERREAU, Alain . Feudalismo: um horizonte teórico. Tradução António José Pinto Ribeiro. Lisboa: Edições 70, 1982, p 211.
} 
Tratando deste mesmo tema, Jacques Le Goff ressalta a importância das florestas, das charnecas e das clareiras cultivadas como característica marcante da Cristandade europeia: a "vitória sobre a floresta", em oposição ao Oriente muçulmano de desertos e oásis. Le Goff enfatiza que para os camponeses o espaço inculto significava fonte de ganho, posto que servia de pasto de porcos e ainda era fonte de madeira, de frutos, de cinzas, de resinas e de $\mathrm{mel}^{30}$.

${ }^{30}$ LE GOFF, Jacques. A civilização do Ocidente Medieval. Tradução José Rivair de Macedo. São Paulo: Edusc, 2002, p. 123-125. 


\section{Le Viandier de Taillevent}

Uma parte considerável da História do Ocidente Medieval não dispõe de fontes escritas, mais precisamente de nenhum tratado de gastronomia, ficando as pesquisas reduzidas a relatos de refeições realizadas durante ocasiões festivas. A partir do século $\mathrm{XIV}$, aparecem os primeiros livros de cozinha, sendo que os primeiros esboços desses livros foram feitos por cozinheiros a serviço da alta nobreza ou de grandes prelados, mas logo suas cópias foram difundidas em meios burgueses. Portanto, não se deve superestimar o caráter aristocrático das receitas. E, de certa forma, a cozinha aristocrática era internacional, pois utilizava um repertório que circulava em toda a Europa.

É importante ressaltar que ao contrário de épocas posteriores, em que um livro de cozinha destinava-se, entre outras coisas, ao ensinamento de receitas, técnicas e preparações, na França Medieval o aprendizado dos cozinheiros se dava pela oralidade e gestualidade. Os manuais lembram apenas a seleção de ingredientes e seu modo de cozimento. Além disso, o registro dessas receitas atesta o prestígio dos reis e príncipes que estimulavam a produção desses manuscritos: a fartura e a variedade, por exemplo, faziam parte da propaganda relativa à riqueza das cortes. Bruno Laurioux observa que a escrita desses livros "privilegia alguns leitores e exclui outros" ${ }^{31}$.

O leitor de um manual de cozinha deveria ser alfabetizado, e embora Payen observe que a alfabetização aumentou a partir do século XII, inclusive nos setores rurais $^{32}$, a maior parte da população, principalmente das mulheres, não sabia ler. Mas, pelo menos, o Viandier é uma obra escrita em vernáculo, o que possibilitou um alcance maior em relação aos textos em latim. E, finalmente, em especial, quando nos referimos às versões manuscritas (que nos interessam pelo recorte temporal), quem possuía disponibilidade financeira para adquirir um livro de cozinha dificilmente era alguém que exercia de fato alguma função na cozinha. Seus leitores, provavelmente, foram mordomos de palácios ${ }^{33}$ ou casas burguesas abastadas, ou o próprio dono da casa, se fosse uma residência mais modesta. E se o leitor não era, como supomos, na maioria das

\footnotetext{
${ }^{31}$ LAURIOUX, Bruno. Le régne de Taillevent: livres et pratiques culinaires a la fin du Moyen Âge. Paris: Publications de La Sorbonne, 1997, passim.

${ }^{32}$ PAYEN, Jean-Charles. Litterature française: Le Moyen Âge. Paris: Arthaud, 1990, passim.

${ }^{33}$ Os mordomos de palácios eram altos dignitários nomeados pelo rei e responsáveis pela administração da casa real.
} 
vezes, a pessoa que estava cozinhando, retornamos à transmissão oral do conhecimento, embora ele esteja catalogado ${ }^{34}$.

É interessante observar que o destinatário final do texto provavelmente não era o seu leitor, mas um terceiro. Concluímos, então, que o texto se destinava a pelo menos dois públicos: aqueles que efetivamente faziam uso de suas instruções e aqueles que liam e transmitiam oralmente essas instruções. E há ainda outro elemento nessa equação: aqueles que consumiam o resultado final dessas instruções: a viande ${ }^{35}$. Da mesma forma, o copista do manuscrito não era necessariamente um cozinheiro. Mais uma vez a oralidade se impõe: possivelmente alguém "ditou" a receita e suas modificações àquele que a compilou.

O Viandier registra os principais traços da cozinha senhorial do século XIV e foi uma das mais difundidas obras de culinária do final da Idade Média, tendo sido inúmeras vezes impresso a partir de 1490. O título completo da compilação de receitas é: Ci aprés sensuyt le viandier pour appareiller toutes manieres de viandes que Taillevent queulx du roi nostre sire fist tant pour abiller et appareiller boullly, rosty, poissons de mer et d'eaue douce, saulces, espices et aultres choses à ce convenables et necessaires comme cy après será dit... (Segue-se o tratado sobre todos os tipos de carnes (iguarias) ${ }^{36}$ que Taillevent, cozinheiro do rei, nosso senhor, escreveu para preparar e aparelhar cozidos, assados, peixes de mar e água doce, molhos, especiarias e outras coisas para isso convenientes e necessárias como adiante será dito...). Viandier dizia respeito a todos os alimentos, pois viande não designava apenas carne, mas o alimento de subsistência ${ }^{37}$; abiller significava preparar uma peça inteira; e appareiller designava a arte de misturar vários produtos ${ }^{38}$.

Em diferentes versões, o Viandier circulou em diversas cortes europeias e teve passagens inteiras compiladas e incorporadas a outras obras do período, inclusive o

\footnotetext{
34 A transmissão do conhecimento volta a ser oral a partir do momento em que ela é transmitida oralmente pela pessoa que leu para aquela que vai executar a ação. Em outras palavras, uma transmissão oral foi provavelmente catalogada em um tratado e depois transmitida oralmente.

${ }^{35}$ Estamos diante de três sujeitos distintos, impactados pelo tratado: quem lê, quem cozinha e quem come. Quase sempre são pessoas diferentes.

${ }^{36}$ É discutível se o termo viande, naquele momento, tratava especificamente de carne ou de iguaria, em geral, como opina Revel.

37 TREFZER, Rudolf. Clássicos da literatura culinária: os mais importantes livros da história da gastronomia. Tradução Marcelo Rondinelli. São Paulo: Senac, 2009, p. 21.

${ }^{38}$ REVEL, Jean-François. Um banquete de palavras: uma história da sensibilidade gastronômica. Paulo Neves. São Paulo: Companhia das Letras, 1996, p. 135.
} 
Ménagier de Paris, apesar do caráter burguês deste último. A relação próxima dos grupos sociais mais elevados levou à disseminação dessas receitas por toda a Europa ${ }^{39}$.

O Viandier não detalha o preparo dos pratos e dos ingredientes, já que se destinava a profissionais do ramo, familiarizados com os procedimentos culinários, mesmo os mais complicados.

As diferentes versões manuscritas do Viandier, a da Bibliothéque Mazarine, da Biblioteca Nacional da França e da Biblioteca do Vaticano, são identificadas como revisões posteriores de um rolo de pergaminho que se encontra no Arquivo Cantonal suíço de Sion, manuscrito do final do século XIII ou início do XIV, anterior ao nascimento de Taillevent.

No final do século XV, o Viandier foi impresso pela primeira vez ${ }^{40}$, obtendo um grande sucesso, embora apenas 80 de suas receitas tenham sido catalogadas. Entre 1468 e 1815 houve 23 edições, de 13 editores diferentes, em Paris, Lyon e Toulouse. Nenhuma alteração significativa foi feita no texto publicado originalmente, nem mesmo nos caracteres utilizados, quase sempre o gótico chamado bastardo, o que denota tratarse de um livro popular, já que caracteres romanos eram mais utilizados em obras eruditas. Sua última edição data do século XVII ${ }^{41}$.

Três exemplares da editio princeps do Viandier (1485-1486) estão preservados. A do Museu Dobrée, em Nantes, pertenceu a Jerôme Pichon e trata-se de uma segunda tiragem, com correções. Nessas edições, as receitas apresentam preparo mais detalhado e algumas unidades de medidas, como onças e libras; além do aumento no uso do açúcar e do gengibre, bem como a introdução do termo "menues espices" (cravo, gengibre, pimenta malagueta, pimenta-do-reino, noz moscada e canela). Também a manteiga substitui a gordura de porco, aparecendo em 50 receitas que não a utilizavam nos manuscritos ${ }^{42}$.

\footnotetext{
39 TREFZER, Rudolf. Clássicos da literatura culinária: os mais importantes livros da história da gastronomia. Tradução Marcelo Rondinelli. São Paulo: Senac, 2009, p. 21-25.

${ }^{40} 1486$ (não confirmado) Taillevent, Cj Apres Sem Suyt le Viandier, Paris (não confirmado), Caillot (não confirmado).

${ }^{41}$ HYMAN, Mary ET Philip. Os livros de cozinha na França entre os séculos XV e XI. In: FLANDRIN, Jean Louis; MONTANARI, Massimo. (Org.). História da Alimentação. Tradução Luciano Vieira Machado; Guilherme J. F. Teixeira. São Paulo: Estação Liberdade, 1998, p. 625-639.

${ }^{42}$ MILANI, Lara Borriero. Para compreender Le Viandier: do estudo do livro medieval de receitas à elaboração de um glossário verbal culinário. 2010. 203 f. Dissertação (Mestrado em Estudos Linguísticos, Literários e tradutológicos em Francês) - Faculdade de Filosofia, Letras e Ciências Humanas, Universidade de São Paulo, São Paulo, 2010, p. 34-35.
} 


\subsection{Guillaume Tirel, dito "Taillevent"}

Guillaume Tirel, dito Taillevent, foi a primeira vedete cristã da gastronomia, um dos primeiros cozinheiros profissionais, cujo nome chegou até os dias de hoje. Sua carreira de mais de 60 anos compreendeu cinco reinados. Teria supostamente registrado as receitas do Viandier a pedido de Carlos V (1338-1380), a quem serviu desde que ainda era delfim de Viennois, e que em 1364 se tornaria o rei da França, tendo se baseado em manuscritos mais antigos, preservados na comuna suíça de Sion $(V A L)$. Foi cozinheiro e portador de título de nobreza de serviços sargent d'armes, conforme documento datado de 1368, e premier queux du roi, conforme documento de 1373. Supõe-se que teria nascido em Pont-Audemer, na Normandia, por volta de 1312, e começado a trabalhar para Joana d'Evreux em 1326. Em 1346 serviu Filipe VI de Valois (1328-1350) e imediatamente após, passou ao serviço do delfim. A partir de 1380, com a morte de Carlos V, serviu Carlos VI (1368-1422), na corte do qual alcançou em 1392 o posto de maistre dês garnisons de cuisine du roi, o mais alto posto de um cozinheiro, maior de todos os encarregados da produção culinária e que podia, inclusive, levar pessoalmente uma bandeja ao rei. Morreu por volta de 1395, com cerca de 80 anos, em boa situação financeira. Sua lápide (Museu de Saint-Germain) o retrata portando armadura de cavaleiro, com três panelas na faixa central do escudo (insígnias da sua classe profissional), entre suas duas esposas ${ }^{43}$.

O posto de Taillevent, quando iniciou sua carreira, a serviço de Joana d'Evreux, esposa de Carlos IV (1322-1328), era de enfant de cuisine, encarregado de depenar aves, escamar peixes, virar espetos e executar outros serviços "menores". Como queux de Felipe VI, exercia a função de cozinheiro, submetido a um mestre, o premier queux, função alcançada por ele no reinado de Carlos VI. Écuyer de cuisine, o topo dessa carreira, foi o posto máximo atingido por Taillevent, homem de confiança do rei, que supervisionava a preparação das refeições reais ${ }^{44}$.

\footnotetext{
${ }^{43}$ TREFZER, Rudolf. Clássicos da literatura culinária: os mais importantes livros da história da gastronomia. Tradução Marcelo Rondinelli. São Paulo: Senac, 2009, p. 20.

${ }^{44}$ MILANI, Lara Borriero. Para compreender Le Viandier: do estudo do livro medieval de receitas à elaboração de um glossário verbal culinário. 2010. 203 f. Dissertação (Mestrado em Estudos Linguísticos, Literários e tradutológicos em Francês) - Faculdade de Filosofia, Letras e Ciências Humanas, Universidade de São Paulo, São Paulo, 2010, p. 37.
} 
Sua sólida fortuna permitiu a construção de uma capela com suntuoso mausoléu em sua propriedade próxima a Saint-Germain-en-Laye, além de suas duas residências em Paris.

Especula-se que o apelido "Taillevent" era devido a seu enorme nariz, "que cortava o vento" ${ }^{, 45}$. Como observa Lara Milani ${ }^{46}$, o costume medieval de atribuir apelidos foi explorado por Rabelais em Le quart livre. Os cozinheiros de Salchichonas são chamados Saupiquet (tipo de molho), Pochecuillère (mete a colher), Hasteret (espetinho), Crêpelet (derivado de crepe), Grasboyau (tripa gorda), Pillemortier (derivado de pilhar e pilão), Lèchevin (lambe vinho), Fressurade (barrigada) e Hachepot (ensopado de carnes e legumes) ${ }^{47}$.

\footnotetext{
${ }^{45}$ Taille vent.

${ }^{46}$ MILANI, Lara Borriero. Para compreender Le Viandier: do estudo do livro medieval de receitas à elaboração de um glossário verbal culinário. 2010. 203 f. Dissertação (Mestrado em Estudos Linguísticos, Literários e tradutológicos em Francês) - Faculdade de Filosofia, Letras e Ciências Humanas, Universidade de São Paulo, São Paulo, 2010, p. 36.

${ }^{47}$ RABELAIS, François. O terceiro livro dos fatos e ditos heróicos do bom Pantagruel. Tradução Élide Valarini Oliver. Cotia: Ateliê Editorial, 2006.
} 


\subsection{Os manuscritos ${ }^{48}$}

Segundo Terence Scully, da coleção de receitas denominada Viandier de Guillaume Tirel ou "Taillenvent", existem hoje quatro manuscritos. Um quinto foi destruído durante a Segunda Guerra Mundial. Sobre tais manuscritos, segue abaixo uma explicação suscinta de suas principais características:

\section{VAL Sion (Suíça) Arquivos Cantonais de Valais, S.108}

\section{8 receitas}

Esse pergaminho, da segunda metade do século XIII, contém somente o Viandier. Possui 13 centímetros de largura por 194,5 cm de comprimento, com texto dos dois lados (o texto ocupa somente dois terços do verso). Um fragmento de 8 a $10 \mathrm{~cm}$ foi cortado e possivelmente continha o título do trabalho (no verso, provavelmente estavam receitas que em outras cópias eram chamadas de Soupe en moustarde. Letras maiúsculas variam entre uma e duas linhas no alto, em vermelho, assim como vários títulos de receitas. É o mais antigo e estilisticamente lacônico dos manuscritos remanescentes.

Jerôme Pichon e Georges Vicaire o reproduziram em foto-facsimile em sua edição de Le Viandier de Guillaume Tirel, dito Taillevent ${ }^{49}$. Uma edição deste livro foi publicada por Paul Aebischer - "Um manuscrito de Valais do Viandier" atribuído a Taillevent, in Vallesia, 8 (1953), 27P. 73-100. A idade do manuscrito de Valais indica que Guillaume Tirel não poderia ter sido o autor da versão original do Viandier $^{50}$.

\section{BN Paris, Bibliothèque Nationale, fonds français, 19, 791}

\section{0 receitas}

Este manuscrito foi a base da edição do Le Viandier, de Guillaume Tirel, dito Taillevent, por Pichon (presidente da Sociedade dos Bibliófilos franceses) e Vicaire (gastrônomo e bibliófilo) $^{51}$, que o publicaram em $1892^{52}$. Data do século XIV, em pele

\footnotetext{
${ }^{48}$ SCULLY, Terence. The Viandier of Taillevent. Ottawa: University of Ottawa Press, 1988, passim.

${ }^{49}$ PICHON, Jerôme; VICAIRE, Georges. Le Viandier de Guillaume Tirel dit Taillevent. Paris: Techener, 1892, p. 257-252.

${ }^{50}$ SCULLY, Terence. The Viandier of Taillevent. Ottawa: University of Ottawa Press, 1988, p. 3.

${ }^{51}$ PICHON, op. cit., p. 30.

${ }^{52}$ Por se tratar de uma edição organizada por amadores, foi considerada medíocre, na opinião de Bruno Laurioux (LAURIOUX, Bruno. Le régne de Taillevent: livres et pratiques culinaires a la fin du Moyen Âge. Paris: Publications de La Sorbonne, 1997. Disponível em: $<$ http://gallica.bnf.fr >. Acesso em: 06 set. 2013).
} 
de carneiro, encadernado. O texto está escrito num único feixe de nove fólios, originalmente não numerados, começando na frente do fólio 1 e terminando no meio do verso do fólio 18. Foram deixados espaços para letras maiúsculas, mas estas nunca foram inseridas. No rodapé do fólio 18(verso) aparece a seguinte anotação: "Este Viandier foi encontrado por mim, Pierre Buffaut".

Trata-se de uma cópia provavelmente escrita durante a vida de Taillevent. No entanto, omite diversas receitas, principalmente de frutos do mar.

\section{VAT Rome, Vatican City, Biblioteca Vaticana, Regina 776 (olim 233 e 2159), ff.48- r-85r. \\ 199 receitas}

A versão é mais extensa que as da Biblioteca Nacional, da Biblioteca Mazarine e dos Arquivos da Mancha (MS. De La Haye-du-Puits). Sua cópia é elegante e cuidadosa.

Data da primeira metade do século XV, em couro de ovelha, 85 fólios de $21 \mathrm{~cm}$ por $15,2 \mathrm{~cm}$. Apresenta letras maiúsculas em vermelho no começo de quase todos os parágrafos, muitas delas ornamentadas. O primeiro trabalho neste documento foi originalmente paginado, mas os números foram trocados quando este trabalho foi incorporado ao manuscrito $V A T$.

Uma transcrição da versão do Viandier, inserida no VAT, foi acrescentada por Pichon e Vicaire em sua edição de $B N$ após Siméon Luce haver dirigido sua atenção para a existência do manuscrito do Vaticano. Sylvie Martinet foi responsável por uma "Nova edição aumentada e revista" do trabalho de Pichon e Vicaire (1892 apud SCULLY, 1988$, p. 55$)^{53}$.

Essa versão anexa duas séries de receitas no fim do Viandier e frequentemente enriquece receitas especificando ingredientes adicionais ou uma maneira alternativa de preparação.

Mas embora seja o mais detalhado dos textos remanescentes, não deve ser interpretado como necessariamente o mais confiável. Tratando-se de livros de receita, a versão mais próxima do rascunho ou compilação do autor original provavelmente é a mais curta, pois existe a tendência a correções, esclarecimentos e adições de receitas suplementares.

\footnotetext{
${ }^{53}$ PICHON, Jêrome and; VICAIRE, Georges. Le Viandier de Guillaume Tirel dit Taillevent. Ed. Sylvie MARTINET. Paris: Techener, 1892.
} 
$M A Z$ Paris, Biblioteca Mazarine, 3636 (oilm 1253), ff. 219 r-228 r.

\section{3 receitas}

O Viandier não representa todo o conteúdo do manuscrito. Produzido no século XV, o volume 3 é classificado como uma reunião de notas de medicina, tábuas aritméticas e astrológicas, entre outros. Pichon e Vicaire apresentam apenas 14 receitas do manuscrito de Mazarine, que não figuram no da Biblioteca Nacional.

Essa versão tentou realizar contribuições àquilo que estava disponível. As modificações indicam que a fonte utilizada para sua cópia foi revisada por um cozinheiro experiente. No entanto, a cópia é descuidada, contendo enganos que ocasionalmente chegam a não fazer sentido, bem como omissão de alguns títulos, grafia de título errado com relação a algumas receitas e cópia de receitas para diferentes peixes, não distinguindo uma da outra.

Saint- Lô. Saint- Lô, Arquivos da Manche, Série E, Arquivos da Baronesa de La Haye-du-puits, ff. 39-v-46r.

Esse manuscrito foi destruído numa fogueira no dia 6 de junho de 1944, durante a Segunda Guerra Mundial. Era datado do século XV e foi numerado algum tempo depois de compilado. Uma nota indicava que as folhas $24,42,43,44$ e 45 estavam faltando. Não se sabe de nenhuma cópia existente. Pichon e Vicaire se referem somente a sete passagens desse documento ${ }^{54}$.

Pichon e Vicaire mencionam vestígios de um manuscrito que pode ter contido uma cópia do Viandier, mas desapareceu. Este volume é descrito no Inventário do Duque de Berry, de 1416, art.919: "Um grande volume, escrito em francês, em letra cursiva, no qual estão contidos os livros que seguem: [10 itens] ... e o último é o Viandier de Taillevent". Este volume de couro também aparece catalogado no Inventário de Santa Geneviève; o Duque pagou 200 moedas de ouro por ele ${ }^{55}$.

Bruno Laurioux identifica, além desses manuscritos, a existência de mais um, na Murhardsche Bibliotheck der Stadt, em Kassel, na Alemanha; e mais dois que foram

\footnotetext{
${ }^{54}$ PICHON, Jerôme; VICAIRE, Georges. Le Viandier de Guillaume Tirel dit Taillevent. Paris: Techener, 1892, passim.

${ }^{55}$ Ibidem, passim.
} 
destruídos durante a Segunda Guerra Mundial, em Orléans e Tours ${ }^{56}$. Quanto ao manuscrito de Kassel, não há unanimidade em considerá-lo manuscrito preservado do Viandier.

\section{MBS Kassel, Murhardsche Bibliotheck der Stadt}

\section{3 receitas}

Nesse manuscrito, o suposto Viandier é denominado Vivendier e é um dos 41 textos que compõem o códice. Sua produção foi estimada entre 1420 e 1440 e apenas 22 de suas receitas aparecem nos outros manuscritos. É possível que o copista tenha apenas selecionado receitas pertencentes a outros livros, entre eles o Viandier, na composição dessa obra. O nome de Taillevent não é mencionado em momento algum ${ }^{57}$.

Os quatro manuscritos estudados por Scully apresentam textos individualmente aproveitáveis e não existe uma boa razão para não supor que o próprio Taillevent tenha sido responsável pelos originais de uma ou de todas as versões contidas no $M A Z, B N$ ou $V A T$. Assim como não há razão para dar mais atenção a qualquer um dos manuscritos, em detrimento dos outros. Tendo a vida profissional de Guillaume Tirel se estendido por 65 anos (1330-1395), é possível que ele mesmo tenha elaborado uma segunda versão do compêndio que leva seu nome. Variantes encontradas no $B N$ e no $V A T$ são originadas de anotações nas margens ou nas entrelinhas de textos mais antigos.

Os manuscritos do Viandier, embora relacionados, não são dependentes de outra cópia conhecida. $V A L$ é o manuscrito mais antigo, mas não é o original nem teve influência direta sobre qualquer das cópias conhecidas. E nenhum dos outros manuscritos (MAZ, BN ou VAT) é original, tampouco uma cópia confiável de um original ou que tenha tido uma influência direta sobre qualquer outra cópia remanescente.

Infelizmente, livros de receita são sujeitos a uma existência desprotegida e ambiente hostil. As três cópias mais recentes do Viandier são limpas e organizadas. Mesmo tratando-se de transcrições descuidadas, são cópias de biblioteca. É possível supor a existência de cópias intervenientes entre os manuscritos remanescentes. As

\footnotetext{
${ }^{56}$ LAURIOUX, Bruno. Le régne de Taillevent: livres et pratiques culinaires a la fin du Moyen Âge. Paris: Publications de La Sorbonne, 1997, passim.

${ }^{57}$ Ibidem, passim.
} 
similaridades e diferenças entre os manuscritos do Viandier permitem supor a existência de pelo menos quatro outros manuscritos, fontes das cópias remanescentes.

$V A L$, do final do século XIII, apresenta erros e peculiaridades que não se encontram nas outras cópias, e é mais relacionado ao $M A Z$ do que a outros manuscritos. Podemos presumir a existência de uma cópia (I), a mais antiga, que originou o manuscrito $V A L . M A Z, B N$ e $V A T$ têm passagens e terminologias comuns, não encontradas em $V A L$, o que sugere sua dependência de um manuscrito comum que não sobreviveu (II). $M A Z$, embora seja o mais desatentamente copiado, possui notáveis alterações individuais, provavelmente feitas por um profissional. Essa pessoa deve ter sido responsável por uma cópia revisada, fonte do $M A Z$ (III), que parece não ter tido influência sobre os outros. $B N$ e $V A T$ são textualmente próximos, relacionados ao compartilhamento de uma fonte comum (IV), produto de alguém que fazia uso frequente de massas. Devem ter sido acrescentadas nessa suposta cópia "IV" esclarecimentos entre linhas ou nas margens, já que $B N$ não as copiou, enquanto $V A T$ apresenta claramente essas modificações. Provavelmente, essa fonte deve ter sido a versão mais extensa, mas não temos a menor evidência de sua existência.

No noroeste da Europa, três trabalhos similares podem ter antecedido o Viandier do VAL. Uma coleção de vinte e nove receitas em dialeto anglo-normando, "Coment l'en deit fere viande e claree", do fim do século XIII, apresenta alguma semelhança, mas não a maior parte de seu conteúdo. A coleção de receitas mais antiga da França e o mais extenso trabalho, cerca de quarenta e seis receitas, é "Vez ci lês enseignemenz qui enseignent a apareillier toutes manieres de viandes" (eis aqui os ensinamentos que instruem como preparar todas as viandas). A composição data de meados de 1300. Se esta obra foi conhecida pelo escritor do original Viandier, ou se o seu autor pode ter lido o que chamamos de manuscrito " $I$ " são apenas possibilidades. Há similaridades elementares entre os dois trabalhos, na apresentação geral de pratos, e ambos compartilham certas receitas (geralmente conhecidas). Mas as receitas no Viandier estão organizadas de acordo com o tipo de carne, ou de acordo com a maneira que esse prato é preparado, enquanto os Enseignements começam com uma sequência de pratos apropriados para cada tipo de carne: porco, vaca, vitela, carneiro, cabrito e cordeiro. O terceiro, a mais antiga coleção de receitas do período medieval, é de origem germana, da primeira metade do século XIII. Neste, há poucos pratos que lembram os do Viandier, mas não parece ter relação próxima com o mesmo. 
Mas o Viandier teve influência em pelo menos dois trabalhos posteriores. Le Ménagier de Paris, de 1393, (com instruções que frequentemente esclarecem o sentido de certas passagens obscuras no Viandier), e o Livre fort excellent de cuysine trés-utile et profitable, impresso em Paris e Lyon por volta de 1540 (muitas das receitas do Viandier são similares, mas a relação é menos próxima do que a Viandier-Ménagier).

Muito da culinária inglesa era proveniente da região francesa. Nesse sentido, a culinária inglesa, copiada em anglo-normando ou inglês, se inspirou na França, mas não há ligações particulares com o Viandier. O mais antigo trabalho culinário inglês é encontrado no manuscrito B.L.Royal 12.C.xii, contendo trinta e duas receitas em língua francesa, datado entre os anos 1320 e 1340 . No entanto, não há relação direta com o Viandier - assim como o Forme of Cury (século XIV), e várias coleções menores em inglês. Do século XV, temos o inglês Liber cure cocorum e os vários manuscritos culinários editados por Thomas Austin.

Ainda sobre a influência da cozinha francesa, duas coleções de receitas italianas do século IV, o Libro della cucina, de um toscano anônimo, e o Libro per cuoco, de um anônimo veneziano, demonstram a influência internacional da referida cozinha, embora também não haja relação direta com o Viandier.

Há três séries de receitas certamente adicionadas ao corpo "original" do Viandier. MAZ tem um conjunto de sete receitas adicionais, escritas pelo mesmo escriba, descrevendo a preparação de pratos aparentemente não relacionados a qualquer material até então copiado. Esses pratos incluem dois molhos, dois pratos de carne, dois pratos com ovo e um de bolinhos fritos em recipiente fundo. As duas outras séries de receitas suplementares são encontradas somente no $V A T$, copiadas por uma mão ligeiramente diferente daquela que escreveu a receita 170. A primeira, A Feitura dos Vinhos, apresenta dez prescrições para melhorar e preservar os vinhos. A segunda apresenta trinta e três receitas para a preparação de pratos, organizados de uma maneira muito geral, numa sequência lógica de ensopados, caldos, tortas, crepes, empadões e entremezes . As receitas são mais complexas, de apresentação impressionante (peçasshow). A prosa do material suplementar do VAT é mais explícita nas instruções. Além disso, aparecem novos ingredientes, formas recheadas não presentes no tradicional Viandier, e até mesmo novas expressões e palavras, o que atesta o aparecimento de novos e mais sofisticados procedimentos no século XV.

Excluídas as adições feitas em $M A Z$ e $V A T$, a sequência de receitas é determinada pelo reconhecimento de dois tipos de carne, de animais e aves, ambos 
domésticos ou selvagens, e de peixe (e outras criaturas aquáticas). Tem inicio com pratos de alimentos fervidos de animais quadrúpedes, domésticos e selvagens, frescos e salgados. Segue uma seção de sopas e ensopados que leva em conta o principal ingrediente e, por extensão, os dias em que seria apropriado comer tais pratos (os dias gordos). O capítulo seguinte apresenta receitas de assados, a maioria de animais domésticos que, segundo o humor galênico, são considerados mais molhados pela natureza e um pouco mais frios do que os selvagens, por isso apropriados para assar. As aves podem ser consideradas uma subdivisão do capítulo. Após os assados, temos entremezes, pratos apresentados entre o $1^{\circ}$ e o $2^{\circ}$ prato (assises, assiettes ou mets) do jantar. O entremez no Viandier é mais leve que uma preparação normal e um pouco mais fantasiado. Pode ser carne, ave ou peixe, ou um cereal fervido.

A $B N$ denomina a série seguinte "Potages lians"; enquanto VAT usa "Potages lians sans char". São receitas de ensopados sem carne, contrapartidas de receitas já apresentadas, alternativas para a Quaresma ou dias da semana em que não se comia carne. O capítulo que segue, "Viandes pour malades" (para doentes), é comum nos livros medievais sobre saúde e nos primeiros livros de receita. A seguir, as receitas de peixe aparecem agrupadas em categorias: peixe de água doce, peixe de água salgada (mar) e peixe de lago. A ordem dos peixes em cada capítulo parece seguir a ordem ideal de preferência, tal qual era determinado por médicos e cientistas da época, com os peixes favoritos em primeiro lugar. No fim desses capítulos estão as receitas de frutos do mar. Em seguida, uma breve seção de três receitas de pratos adicionais oferece mais possibilidades para a Quaresma.

Dois capítulos sobre molhos são originais do Viandier : molhos frios e quentes. Os frios usam principalmente canela e alho; os quentes, pimenta e gengibre. Uma lista de condimentos segue as receitas de molhos no $B N$ e no $V A T$.

\footnotetext{
${ }^{58}$ Cabe observar que nem todas as receitas dessa sessão contêm carne.
} 


\section{A CARNE E O OCIDENTE MEDIEVAL CRISTÃO}

\subsection{A carne no Ocidente Antigo e as mudanças}

\section{medievais}

Entre o VII e III milênio a.C. desenvolveu-se no centro-norte da Europa o grupo conhecido pela arqueologia como "cultura danubiana" ou "cultura da cerâmica linear". Marija Gimbutas chamou-os de "Civilização da Velha Europa" primeiros agricultores dessa região, itinerantes de cultura igualitária, que ocupavam florestas fechadas, utilizando técnicas de queimadas e cultivando principalmente cereais, lentilha e linho.

Em torno de 2500 a.C penetraram na Europa Central, em várias “ondas", grupos culturais que deram origem aos ramos grego, itálico, celta e germânico das línguas indoeuropeias $^{60}$. Proveniente das estepes do norte do Mar Negro e chamada de "Cultura dos Machados de Guerra", caracterizava-se pela presença de machados de guerra e vasos de bebida, encontrados em tumbas individuais, indicando a importância dos guerreiros sepultados. Essas sociedades eram mais estratificadas e baseavam seus valores na posse de grandes rebanhos, muito mais que na produção agrícola ${ }^{61}$.

\footnotetext{
${ }^{59}$ GIMBUTAS, Marija. The civilization of the goddess. San Francisco: Harper, 1991, passim.

${ }^{60}$ SERGENT, Bernard. Os indo-europeus: gênese e expansão de uma cultura. In: LÉVÊQUE, Pierre. (Dir.). As primeiras civilizações. Lisboa: Edições 70, 1990. p. 9-144.

${ }^{61}$ PIGGOTT, Stuart. A Europa Antiga: do início da agricultura à Antiguidade Clássica. Lisboa: Caloust Gulbekian, 1981, passim.
} 
Nessa época ocorreu um desflorestamento das paisagens europeias, ao mesmo tempo em que cresceu a importância dos rebanhos e das elites guerreiras ${ }^{62}$. Esses guerreiros caracterizavam-se pela "embriaguez de honra", equiparada à "loucura divina" do furor militar, que tornava o guerreiro sedento do sangue do inimigo e uma pessoa incontrolável. O termo usado pelos escandinavos para designar a embriaguez alcoólica era o mesmo utilizado para designar a fúria dos guerreiros vitoriosos ${ }^{63}$.

A ideia de conquista guerreira ocupava o lugar central na mentalidade indoeuropeia. Nas assembleias os guerreiros consumiam vorazmente bens etílicos e alimentares (principalmente carne), em banquetes com enorme distribuição de comida e bebida, que visavam demonstrar o poder econômico do anfitrião. Cada um buscava obter a melhor parte do banquete reservada ao mais forte e corajoso, ao mesmo tempo em que se vangloriava de seus feitos. Era o que os gregos chamaram de "parte da honra" ${ }^{64}$. Já no Mediterrâneo, desenvolveram-se as civilizações da tríade vinho, trigo e azeite, emblemas de civilização e de trabalho do homem, bem como do domínio sobre a natureza selvagem.

A cultura greco-romana perseguia o ideal da moderação: o alimento deveria ser consumido com prazer, não voracidade, e oferecido de forma generosa, não com ostentação. Mesmo havendo relatos de desperdício ou excessiva renúncia na história dessa cultura, esses apresentam sempre tom de desprezo e suspeita.

No período clássico, a concepção dos gregos e dos chamados bárbaros a respeito do que seria um comportamento adequado se tornara totalmente diferente. Os celtas e germânicos mantiveram as tradições indo-europeias da embriaguez heroica, símbolos de dominação cultural do seu grupo sobre o anteriormente estabelecido. As elites gregas, a essa altura, já haviam abandonado essa tradição e adotado um ideal de moderação.

Desde o período homérico a nobreza de sangue desenvolvera uma relação comedida e cerimonial com a embriaguez ${ }^{65}$. No entanto, ainda bebia-se e comia-se muito nas festas religiosas populares da Grécia. Tais manifestações estavam bastante relacionadas à cultura indo-europeia e às elites helênicas pareciam selvagens e

\footnotetext{
${ }^{62}$ SHERRAT, Andrew. Envisioning global change: a long-term perspective. Denemark, 2000.

63 SERGENT, Bernard. Os indo-europeus: gênese e expansão de uma cultura. In: LÉVÊQUE, Pierre. (Dir.). As primeiras civilizações. Lisboa: Edições 70, 1990. p. 9-144.

${ }^{64}$ Ibidem, p. 9 et seq.

${ }^{65} \mathrm{O}$ symposium era sim reminiscência dos banquetes guerreiros indo-europeus, mas diferenciavam-se quanto ao refinamento e à prática da moderação etílica. Consumir vinho adequadamente identificava o lugar do indivíduo na sociedade, separava os melhores do restante da turba.
} 
primitivas. Cabia aos homens superiores diferenciarem-se do populacho desregrado e dos bárbaros selvagens, desconhecedores das sutilezas do cerimonial ${ }^{66}$.

Os romanos usaram mais o álcool e os alimentos como meio de intercâmbio cultural e étnico, como símbolo de sua suposta superioridade. Mesmo o comportamento nórdico, no que diz respeito ao álcool, era uma forma de estabelecer uma contraposição cultural ao regime romano.

Os primeiros romanos viviam em comunidades pastoris, e a noção de virtus, a valorização da permanência e a condenação do inovador, dirigia todo o sistema cultural dos clãs tradicionais, as gentes. Condenava-se todo tipo de excesso, que levaria à preguiça e à fraqueza no trabalho e na batalha. Essa sociedade apresentava grande frugalidade alimentar, uma dieta baseada em papa de espelta $\left(p u s^{67}\right)$, legumes cozidos, carne de porco salgada, maçãs, peras e bolotas de carvalho. A carne bovina era preciosa demais para ser consumida.

A alimentação dos mediterrâneos caracterizava-se pela forte conotação vegetal: farináceos, pão, vinho, óleo e verduras. Pouca carne e muito queijo. Ovelhas e cabras eram prioritariamente fontes de leite e lã. Da carne era possível prescindir. O luxo, por excelência, era a fruta. Os escritores gregos e latinos imaginavam uma Idade de Ouro vegetariana, similar ao Éden bíblico ${ }^{68}$.

As conquistas entre os séculos IV e II a.C. solaparam a rusticidade e trouxeram influências helênicas e orientais. A dieta tradicional foi revolucionada. O trigo tornou-se acessível com as produções do sul da Itália e da Etrúria. Roma desenvolveu uma indústria alimentícia voltada para o consumo das massas urbanas e o pão passou a ser o alimento principal. A partir de então, pão e vinho tornaram-se símbolos da alimentação civilizada.

Os pobres da Roma Antiga não comiam e nem bebiam em casa, comprando nas tabernae $^{69}$ ou recebendo alimentos na annona $^{70}$. Quem tinha posição social elevada

\footnotetext{
${ }^{66}$ VETTA, Massimo. A cultura do symposium. In: FLANDRIN, Jean Louis; MONTANARI, Massimo. (Org.). História da alimentação. Tradução Luciano Vieira Machado; Guilherme J. F. Teixeira. São Paulo: Estação Liberdade, 1998, p. 170-185.

${ }^{67}$ A puls era a papa de cereais.

${ }^{68}$ MONTANARI, Massimo A fome e a abundância: história da alimentação na Europa. Tradução Andréa Doré. São Paulo: Edusc, 2003, passim.

${ }^{69} \mathrm{O}$ termo refere-se à taberna, loja de bebidas onde também se podia comer - um lugar de frequência popular, em que as hierarquias eram supostamente anuladas.

70 O termo significa "provisões", as provisões que o governo do Império Romano distribuía ao povo. Annona era a divindade romana ligada à provisão, em estreita relação com Ceres e direta relação com o culto imperial. Seu culto era difundido e sua imagem associada ao imperador. Por meio dessa propaganda
} 
oferecia banquetes, nos quais convidados de diferentes categorias hierárquicas consumiam comidas e bebidas diferentes, de acordo com seus estatutos sociais distintos. Destaque-se que era considerada falta de elegância servir comida e bebida sem o devido respeito à ordem hierárquica ${ }^{71}$.

Já os chamados bárbaros não colocavam a marca humana no que consumiam, o que contribuiu, de certa forma, para a confirmação, por parte de certos grupos, de que eram homens inferiores.

Com relação ao termo "celta", tal designação diz respeito a diversos povos diferentes que compartilhavam certos traços culturais, dentre os quais a realização dos banquetes cerimoniais. Durante tais banquetes, a aristocracia guerreira disputava uma "parte de honra", de carne e bebida. Os grupos celtas compartilhavam com os germânicos a valorização do consumo exagerado de comida e álcool.

O sistema alimentar das populações celtas e germânicas se baseava na caça, pesca, coleta de frutos silvestres, criação de animais selvagens nos bosques, como os bovinos e equinos, mas principalmente porcos. Seu alimento mais importante era a carne e para cozinhá-la se usava manteiga e toucinho.

Para celtas e germânicos, o comedor voraz era digno de apreciação por sua superioridade animalesca, sua aproximação simbólica dos animais ferozes, como ursos e lobos. Na Edda islandesa, Loki desafia os presentes a comerem mais carne que ele, e é vencido por Logi, que come também os ossos e o prato. Em seguida, Thorr inicia uma disputa para verificar quem seria capaz de beber mais. Carlos Magno (742-814 d. C.), julgou um certo comensal um "fortíssimo soldado", por vê-lo descarnar e esmigalhar grande quantidade de ossos, chupando o miolo. E Liutprando de Cremona (922-972 d.C.) relatou que Guido, o duque de Espoleto, teve o trono da França recusado, no século X, por alimentar-se com moderação ${ }^{72}$.

É provável que os germânicos também tivessem o hábito de comer cereais. E certo que os imperadores romanos distribuíam ao povo carne de porco junto com pão.

político-religiosa (a ligação direta com Annona), o imperador reforçava a imagem de provedor de seu povo.

${ }^{71}$ VEYNE, Paul. O Império Romano. In: ARIES, Philippe; DUBY, George. (Org.). Do Império Romano ao ano mil. Tradução Maria Lucia Machado. São Paulo: Companhia das Letras, v. 1, 2002, passim.

72 MONTANARI, Massimo. A fome e a abundância: história da alimentação na Europa. Tradução Andréa Doré. São Paulo: Edusc, 2003, p. 36-37. 
Mas a posição e a importância desses alimentos em cada um desses sistemas alimentares é claramente oposta ${ }^{73}$.

Os chamados povos bárbaros não deixavam de ter considerável atração pelos produtos urbanos das civilizações antigas, que adquiriam um valor ideológico maior que o utilitário. Sherrat considera que novas práticas de consumo foram promovidas com a expansão de um regime de valores hegemônicos, partindo desses centros urbanos em direção à periferia do sistema ${ }^{74}$. No entanto, apesar do vinho ter se expandido entre os povos do centro-norte europeu, não foi automática a expansão dos hábitos alimentares dos chamados bárbaros entre os gregos e romanos.

No século I, Tácito (56-117 d.C.) (98 d.C. apud FERNANDES, 2004, p. 198) apontou características supostamente "bárbaras" dos germânicos que habitavam o Reno, que se alimentavam principalmente de carne e leite coalhado. Sinalou que estes povos esperavam que um guerreiro viril fosse capaz de beber uma grande quantidade de álcool enquanto que para os gregos, a sobriedade em relação à comida e bebida era ponto chave da educação ${ }^{75}$. Mas não tardou muito para que os elementos da cultura alimentar desses povos invadissem a sociedade mediterrânea. A carne passou a ser valorizada como alimento típico da elite e seu consumo perdeu o caráter de selvageria. O que não ocorria antes, quando, além da tríade pão, azeite, vinho, distinguia-se o consumo de vegetais. A partir das conquistas germânicas, a carne tornou-se apanágio da elite guerreira, da conquista do poder através das armas.

Vale observar que o contato dos celtas com os romanos deu-se quando estes estavam no auge da força militar e do desenvolvimento cultural e político. Nesse caso a influência foi maior dos romanos sobre os centro-europeus. Já o contato entre germânicos e romanos deu-se quando a sociedade romana já estava profundamente transformada em relação ao início do Império. Quando a sociedade romana, de certo modo, germanizava-se. O próprio Maximino (173-238), o Trácio, imperador de origem germânica, filho de um godo e de uma alana, bebia, para escândalo dos cronistas, uma ânfora de vinho por dia, puro. Seu filho, Maximino, o Jovem, dizem, só comia carne de caça. E Firmo devoraria uma avestruz por dia $^{76}$.

\footnotetext{
73 MONTANARI, Massimo. A fome e a abundância: história da alimentação na Europa. Tradução Andréa Doré. São Paulo: Edusc, 2003, p. 20.

${ }^{74}$ SHERRAT, Andrew. Envisioning global change: a long-term perspective. Denemark, 2000, passim.

${ }^{75}$ TACITUS. Germânia: de origine et situ germanorum. Tradução João Penteado Erskine Stevenson. São Paulo: Brasil editora, 1952. (Biblioteca de autores célebres, 24).

${ }^{76}$ MONTANARI, op. cit., p. 24.
} 
Celtas, germânicos e outros povos, como os hunos, oriundos das estepes asiáticas, valorizavam produtos considerados de uso da "civilização", e suas elites utilizavam esses bens estrangeiros para manter influência e legitimar seu poder. Tais bens de prestígio, bem como sua distribuição, eram um meio de garantir o relacionamento e a lealdade entre chefes e guerreiros. Dominie Ingemark ressalta que distinções hierárquicas tornaram-se cada vez mais agudas, ao ponto de não saber como usar cálices tornar-se uma falha humilhante ${ }^{77}$.

Em 448, Teodósio II (401-450) enviou uma embaixada a Átila (406-453), rei dos hunos, da qual o historiador Priscus fazia parte. Priscus observou que o vinho e a carne eram usados como marcadores de diferenciação hierárquica entre os próprios hunos. Quando chegou a uma determinada cidade, Átila recebeu "a maior honra que podia ser feita entre os citas": foi servido de carne e vinho pelas esposas dos nobres ${ }^{78}$.

Os banquetes dos ricos e as festas dionisíacas dos pobres romanos deixaram de existir em suas formas tradicionais a partir do fim do Império do Ocidente ${ }^{79}$.

Da articulação dessas culturas resultou que, do ponto de vista ideológico, pão e carne tornaram-se alimentos primordiais e indispensáveis. ${ }^{80}$.

\footnotetext{
${ }^{77}$ INGEMARK, Dominic. Glass, alcoholand power in RomanIron Age Scotland: a study of the Roman vesselglass from non-Roman/ native sitesin north Northumberland and Scotland. Doctoral Dissertation. Lund University, 2003, passim.

78 PRISCUS. Fragmenta Historicum Graecorum. Disponível em: $<$ htpp/ccat.sas.upenn.edu/jod/texts/priscus.html>. Acesso em: 23 fev. 2012 (Fragmento 8).

${ }^{79}$. FERNANDES, João Azevedo. Selvagens bebedeiras: álcool, embriaguez e contatos culturais no Brasil colonial. 2004. 392 f. Tese (Doutorado em História) - Departamento de História, Universidade Federal Fluminense, Rio de Janeiro, 2004, p. 205.

${ }^{80}$ MONTANARI, Massimo. A fome e a abundância: história da alimentação na Europa. Tradução Andréa Doré. São Paulo: Edusc, 2003, p. 35.
} 


\subsection{Os tipos de carne e a relevância social}

\subsubsection{A importância social}

Os grupos sociais considerados inferiores agarraram-se com mais tenacidade às suas tradições alimentares. Nas áreas romanas submetidas ao poder germânico, as camadas superiores assimilaram rapidamente a paixão pela caça e o alto consumo de carne. Os mais humildes conservaram a alimentação constituída predominantemente por vegetais. No norte, o pão, o vinho e o óleo ganharam espaço entre os grupos dominantes. Mas ainda assim, em praticamente toda a Europa, as camadas mais humildes começaram a comer mais carne ${ }^{81}$.

As classes dominantes afirmavam constantemente o valor da carne, associada ao poder, à energia, ao vigor e ao combate. A abstinência de carne adquiriu sentido de humilhação e marginalização. Os capitulares francos chegaram a colocá-la no mesmo plano da deposição de armas, que implicava na mudança total de vida para o guerreiro. Lotário (795-855 d.C.), no século IX, prescreve ambas para quem tenha assassinado um bispo $^{82}$.

O comportamento alimentar era o primeiro modo de diferenciação social. A qualidade e a natureza de um alimento definiam a classe de pertença, bem como a qualidade da pessoa. A carne, principalmente de caça, era símbolo da nobreza guerreira. Comer muito, sobretudo muita carne, era símbolo de poder, fonte de energia física e potência sexual, além de representar a manifestação da felicidade e da alegria de viver.

A natureza nobre ou vulgar de um alimento era uma analogia entre o mundo criado por Deus e o mundo dos homens, e organizava-se de acordo com o princípio hierárquico vertical denominado "grande cadeia do ser", na qual cada elemento tinha seu lugar. Todas as plantas e animais pertenciam a um dos quatro segmentos estabelecidos pelos elementos terra, água, fogo e ar. As plantas eram o elemento mais baixo. Em segundo lugar estavam os animais aquáticos e em terceiro, os pássaros. Os quadrúpedes, por sua vez, ficavam acima dos vegetais e abaixo das aves. Já o porco era o mais baixo da lista. As aves eram consideradas adequadas à alimentação das classes

${ }^{81}$ MONTANARI, Massimo. A fome e a abundância: história da alimentação na Europa. Tradução Andréa Doré. São Paulo: Edusc, 2003, p. 45.

${ }^{82}$ Ibidem, p. 41. 
superiores e os quadrúpedes recomendados aos mercadores. Já as pessoas pertencentes às classes inferiores deveriam idealmente alimentar-se de legumes ${ }^{83}$.

Para os homens do Ocidente Medieval, as aves domésticas e as caças constituíam os assados nobres. Segundo a Antropologia, o simbolismo do assado sobre a chama, que invoca a violência, a impetuosidade, a belicosidade e a selvageria, é o oposto da representação da água fervente na panela. Já as carnes de açougue, principalmente a bovina, eram mais utilizadas na preparação de caldos, picadinhos e sopas.

A tabela a seguir demonstra de que forma, quanto ao preparo, as receitas que utilizam carne como seu ingrediente principal se apresentam no Viandier (considerando apenas as anteriores ao século XV).

Tabela 1 - Preparo das receitas no Viandier

\begin{tabular}{|c|c|c|c|c|c|c|c|c|}
\hline RECEITA & SEÇÃO & $\begin{array}{l}\text { MODO DE } \\
\text { PREPARO }\end{array}$ & $\begin{array}{l}\text { TIPO DE } \\
\text { CARNE }\end{array}$ & ESPÉCIE & \multicolumn{4}{|c|}{$\begin{array}{c}\text { CONSTANTE NOS } \\
\text { MANUSCRITOS }\end{array}$} \\
\hline Fervura de carne gorda & Sopas gordas & cozido & quadrúpede & $\begin{array}{c}\text { vaca } \\
\text { porco } \\
\text { carneiro }\end{array}$ & & $\mathrm{BN}$ & MAZ & VAT \\
\hline Retalhado de carneiro & Sopas gordas & cozido & quadrúpede & carneiro & & $\mathrm{BN}$ & MAZ & VAT \\
\hline Carnes entremeadas & Sopas gordas & cozido & quadrúpede & & VAL & $\mathrm{BN}$ & MAZ & VAT \\
\hline Veadada de veado fresco & Sopas gordas & $\begin{array}{l}\text { cozido } \\
\text { empada }\end{array}$ & quadrúpede & veado & VAL & & MAZ & VAT \\
\hline Javali & Sopas gordas & $\begin{array}{l}\text { cozido } \\
\text { cozido }\end{array}$ & $\begin{array}{l}\text { quadrúpede } \\
\text { quadrúpede }\end{array}$ & $\begin{array}{l}\text { javali } \\
\text { veado }\end{array}$ & VAL & $\mathrm{BN}$ & MAZ & VAT \\
\hline Cabra selvagem & Sopas gordas & $\begin{array}{l}\text { cozido } \\
\text { empada }\end{array}$ & quadrúpede & cabra & VAL & $\mathrm{BN}$ & MAZ & \\
\hline Capões ou vitela com ervas & Sopas gordas & $\begin{array}{l}\text { cozido } \\
\text { cozido } \\
\end{array}$ & $\begin{array}{c}\text { ave } \\
\text { quadrúpede } \\
\end{array}$ & $\begin{array}{l}\text { capão } \\
\text { vitela }\end{array}$ & & $\mathrm{BN}$ & & VAT \\
\hline Caldo quente de porco & Sopas gordas & cozido & quadrúpede & porco & VAL & $\mathrm{BN}$ & MAZ & VAT \\
\hline Cretonada de ervilhas & Sopas gordas & cozido & ave & galinha & VAL & $\mathrm{BN}$ & MAZ & VAT \\
\hline Cretonada de favas & Sopas gordas & cozido & ave & galinha & & $\mathrm{BN}$ & MAZ & VAT \\
\hline Cuminade de aves & Sopas gordas & cozido & ave & & VAL & $\mathrm{BN}$ & MAZ & VAT \\
\hline Cuminade de amêndoas & Sopas gordas & cozido & ave & & VAL & $\mathrm{BN}$ & & VAT \\
\hline Caldo de canela & Sopas gordas & $\begin{array}{l}\text { cozido } \\
\text { cozido }\end{array}$ & $\begin{array}{c}\text { ave } \\
\text { quadrúpede } \\
\end{array}$ & & VAL & $\mathrm{BN}$ & MAZ & VAT \\
\hline Caldo georgié & Sopas gordas & cozido & ave & doméstica & $\mathrm{VAL}$ & $\mathrm{BN}$ & MAZ & VAT \\
\hline Caldo ruivo & Sopas gordas & $\begin{array}{l}\text { cozido } \\
\text { cozido }\end{array}$ & $\begin{array}{c}\text { quadrúpede } \\
\text { ave }\end{array}$ & & VAL & $\mathrm{BN}$ & MAZ & VAT \\
\hline
\end{tabular}

${ }^{83}$ GRIECO, Allen F. Alimentação e classes sociais no fím da Idade Média e na Renascença. In: FLANDRIN, Jean Louis; MONTANARI, Massimo. (Org.). História da alimentação. Tradução Luciano Vieira Machado; Guilherme J. F. Teixeira. São Paulo: Estação Liberdade, 1998, p. 466. 


\begin{tabular}{|c|c|c|c|c|c|c|c|c|}
\hline RECEITA & SEÇÃO & $\begin{array}{l}\text { MODO DE } \\
\text { PREPARO } \\
\end{array}$ & $\begin{array}{l}\text { TIPO DE } \\
\text { CARNE } \\
\end{array}$ & ESPÉCIE & \multicolumn{4}{|c|}{$\begin{array}{c}\text { CONSTANTE NOS } \\
\text { MANUSCRITOS }\end{array}$} \\
\hline Vísceras de porco & Sopas gordas & cozido & quadrúpede & porco & VAL & $\mathrm{BN}$ & MAZ & VAT \\
\hline Molho de pássaros & Sopas gordas & cozido & ave & & $\mathrm{VAL}$ & $\mathrm{BN}$ & MAZ & VAT \\
\hline Caldo branco de capões & Sopas gordas & cozido & ave & capão & $\mathrm{VAL}$ & $\mathrm{BN}$ & MAZ & VAT \\
\hline $\begin{array}{l}\text { Aferventado de lebres } \\
\text { ou coelhos }\end{array}$ & Sopas gordas & $\begin{array}{l}\text { cozido } \\
\text { cozido }\end{array}$ & $\begin{array}{l}\text { quadrúpede } \\
\text { quadrúpede }\end{array}$ & $\begin{array}{c}\text { lebre } \\
\text { coelho }\end{array}$ & VAL & $\mathrm{BN}$ & MAZ & VAT \\
\hline Aferventado de capões & Sopas gordas & cozido & ave & capão & VAL & $\mathrm{BN}$ & MAZ & VAT \\
\hline $\begin{array}{l}\text { Caldo alemão de coelhos } \\
\text { ou aves }\end{array}$ & Sopas gordas & $\begin{array}{l}\text { cozido } \\
\text { cozido }\end{array}$ & $\begin{array}{c}\text { quadrúpede } \\
\text { ave }\end{array}$ & coelho & VAL & $\mathrm{BN}$ & MAZ & VAT \\
\hline Mexido de aves & Sopas gordas & cozido & ave & & VAL & $\mathrm{BN}$ & MAZ & VAT \\
\hline Rápido caldo inglês & Sopas gordas & cozido & quadrúpede & porco & $\mathrm{VAL}$ & $\mathrm{BN}$ & MAZ & VAT \\
\hline Caldo de agraço & Sopas gordas & $\begin{array}{l}\text { cozido } \\
\text { cozido } \\
\end{array}$ & $\begin{array}{c}\text { quadrúpede } \\
\text { ave }\end{array}$ & & VAL & $\mathrm{BN}$ & & VAT \\
\hline Caldo amarelo-verde & Sopas gordas & $\begin{array}{l}\text { cozido } \\
\text { cozido } \\
\end{array}$ & $\begin{array}{c}\text { quadrúpede } \\
\text { ave }\end{array}$ & & VAL & $\mathrm{BN}$ & MAZ & VAT \\
\hline Rappé & Sopas gordas & $\begin{array}{l}\text { cozido } \\
\text { cozido } \\
\end{array}$ & $\begin{array}{c}\text { quadrúpede } \\
\text { ave }\end{array}$ & & VAL & $\mathrm{BN}$ & MAZ & VAT \\
\hline Guisado de vitela & Sopas gordas & cozido & quadrúpede & vitela & VAL & $\mathrm{BN}$ & MAZ & VAT \\
\hline Guisado de lebres & Sopas gordas & cozido & quadrúpede & lebre & VAL & $\mathrm{BN}$ & MAZ & VAT \\
\hline Guisado de coelhos & Sopas gordas & cozido & quadrúpede & coelho & & $\mathrm{BN}$ & & VAT \\
\hline Porco assado & Carnes Assadas & $\begin{array}{l}\text { assado } \\
\text { empada }\end{array}$ & $\begin{array}{l}\text { quadrúpede } \\
\text { quadrúpede }\end{array}$ & $\begin{array}{l}\text { porco } \\
\text { porco }\end{array}$ & VAL & $\mathrm{BN}$ & MAZ & VAT \\
\hline Vitela assada & Carnes Assadas & $\begin{array}{l}\text { assado } \\
\text { empada }\end{array}$ & $\begin{array}{l}\text { quadrúpede } \\
\text { quadrúpede }\end{array}$ & $\begin{array}{l}\text { vitela } \\
\text { vitela } \\
\end{array}$ & & $\mathrm{BN}$ & MAZ & VAT \\
\hline Desfiado de bezerro & Carnes Assadas & frito & quadrúpede & bezerro & VAL & $\mathrm{BN}$ & MAZ & VAT \\
\hline Carneiro assado & Carnes Assadas & assado & quadrúpede & carneiro & VAL & $\mathrm{BN}$ & MAZ & VAT \\
\hline Cabras novas, cordeiros & Carnes Assadas & assado & $\begin{array}{l}\text { quadrúpede } \\
\text { quadrúpede }\end{array}$ & $\begin{array}{c}\text { cordeiro } \\
\text { cabra }\end{array}$ & VAL & $\mathrm{BN}$ & MAZ & VAT \\
\hline Gansos & Carnes Assadas & assado & ave & ganso & $\mathrm{VAL}$ & $\mathrm{BN}$ & MAZ & VAT \\
\hline Galinhas assadas & Carnes Assadas & $\begin{array}{l}\text { assado } \\
\text { empada }\end{array}$ & $\begin{array}{l}\text { ave } \\
\text { ave }\end{array}$ & $\begin{array}{l}\text { galinha } \\
\text { galinha }\end{array}$ & VAL & $\mathrm{BN}$ & MAZ & VAT \\
\hline Capões, galinhas e galos & Carnes Assadas & assado & ave & $\begin{array}{c}\text { capão } \\
\text { galinha } \\
\text { galo }\end{array}$ & VAL & $\mathrm{BN}$ & MAZ & VAT \\
\hline Coelhos assados & Carnes Assadas & $\begin{array}{l}\text { assado } \\
\text { empada }\end{array}$ & $\begin{array}{l}\text { quadrúpede } \\
\text { quadrúpede }\end{array}$ & $\begin{array}{l}\text { coelho } \\
\text { coelho } \\
\end{array}$ & VAL & $\mathrm{BN}$ & MAZ & VAT \\
\hline Capões gordurosos & Carnes Assadas & assado & ave & capão & & & & VAT \\
\hline Lebres assadas & Carnes Assadas & $\begin{array}{l}\text { assado } \\
\text { empada }\end{array}$ & $\begin{array}{l}\text { quadrúpede } \\
\text { quadrúpede }\end{array}$ & $\begin{array}{l}\text { lebre } \\
\text { lebre }\end{array}$ & VAL & $\mathrm{BN}$ & MAZ & VAT \\
\hline Atoleiro de javali fresco & Carnes Assadas & assado & quadrúpede & javali & VAL & $\mathrm{BN}$ & MAZ & VAT \\
\hline Todos os veados frescos & Carnes Assadas & assado & quadrúpede & veado & & $\mathrm{BN}$ & MAZ & VAT \\
\hline Pombas assadas & Carnes Assadas & $\begin{array}{l}\text { assado } \\
\text { empada }\end{array}$ & $\begin{array}{l}\text { ave } \\
\text { ave } \\
\end{array}$ & $\begin{array}{l}\text { pomba } \\
\text { pomba } \\
\end{array}$ & VAL & $\mathrm{BN}$ & & VAT \\
\hline Pássaros pequenos & Carnes Assadas & $\begin{array}{l}\text { assado } \\
\text { empada }\end{array}$ & $\begin{array}{l}\text { ave } \\
\text { ave }\end{array}$ & $\begin{array}{l}\text { pássaros pequenos } \\
\text { pássaros pequenos }\end{array}$ & VAL & $\mathrm{BN}$ & MAZ & VAT \\
\hline Carambolas e galinholas & Carnes Assadas & $\begin{array}{l}\text { assado } \\
\text { empada }\end{array}$ & $\begin{array}{l}\text { ave } \\
\text { ave }\end{array}$ & $\begin{array}{c}\text { carambola } \\
\text { galinhola } \\
\text { carambola } \\
\text { galinhola } \\
\end{array}$ & & $\mathrm{BN}$ & & VAT \\
\hline Perdiz & Carnes Assadas & $\begin{array}{l}\text { assado } \\
\text { empada }\end{array}$ & $\begin{array}{l}\text { ave } \\
\text { ave }\end{array}$ & $\begin{array}{l}\text { perdiz } \\
\text { perdiz } \\
\end{array}$ & VAL & $\mathrm{BN}$ & MAZ & VAT \\
\hline Rolas & Carnes Assadas & assado & ave & rola & & $\mathrm{BN}$ & & VAT \\
\hline
\end{tabular}




\begin{tabular}{|c|c|c|c|c|c|c|c|c|}
\hline \multirow[t]{2}{*}{ RECEITA } & \multirow[t]{2}{*}{ SEÇÃO } & \multirow{2}{*}{$\begin{array}{c}\text { MODO DE } \\
\text { PREPARO } \\
\text { empada } \\
\end{array}$} & \multirow{2}{*}{$\begin{array}{c}\text { TIPO DE } \\
\text { CARNE } \\
\text { ave } \\
\end{array}$} & \multirow{2}{*}{$\begin{array}{c}\text { ESPÉCIE } \\
\text { rola } \\
\end{array}$} & \multicolumn{4}{|c|}{$\begin{array}{c}\text { CONSTANTE NOS } \\
\text { MANUSCRITOS }\end{array}$} \\
\hline & & & & & & & & \\
\hline Cisnes & Carnes Assadas & assado & ave & cisne & VAL & $\mathrm{BN}$ & MAZ & VAT \\
\hline Pavões & Carnes Assadas & assado & ave & pavão & VAL & $\mathrm{BN}$ & MAZ & VAT \\
\hline Faisões & Carnes Assadas & assado & ave & faisão & VAL & $\mathrm{BN}$ & MAZ & VAT \\
\hline Cegonhas & Carnes Assadas & assado & ave & cegonha & VAL & $\mathrm{BN}$ & MAZ & VAT \\
\hline Garças-reais & Carnes Assadas & assado & ave & garça & VAL & $\mathrm{BN}$ & MAZ & VAT \\
\hline Pato-real do rio & Carnes Assadas & assado & ave & pato do rio & VAL & $\mathrm{BN}$ & MAZ & VAT \\
\hline Abetardos, gansos e grous & Carnes Assadas & assado & ave & $\begin{array}{c}\text { abetardo } \\
\text { ganso selvagem } \\
\text { grou } \\
\end{array}$ & VAL & $\mathrm{BN}$ & MAZ & VAT \\
\hline Alcaravões & Carnes Assadas & assado & ave & alcavarão & & $\mathrm{BN}$ & & VAT \\
\hline Cormorões & Carnes Assadas & assado & ave & cormorão & VAL & $\mathrm{BN}$ & MAZ & VAT \\
\hline Colhereiros & Carnes Assadas & assado & ave & colheiro & & & & VAT \\
\hline Marrequinho & Carnes Assadas & assado & ave & marrequinho & & & & VAT \\
\hline $\begin{array}{l}\text { Leitão recheado } \\
\text { Falso grenon }\end{array}$ & $\begin{array}{l}\text { Carnes Assadas } \\
\text { Entremezes }\end{array}$ & $\begin{array}{l}\text { assado } \\
\text { cozido } \\
\text { cozido } \\
\end{array}$ & $\begin{array}{l}\text { quadrúpede } \\
\text { ave } \\
\text { quadrúpede } \\
\end{array}$ & $\begin{array}{c}\text { leitão } \\
\text { ave doméstica } \\
\text { vitela } \\
\end{array}$ & $\begin{array}{l}\text { VAL } \\
\text { VAL }\end{array}$ & $\begin{array}{l}\mathrm{BN} \\
\mathrm{BN}\end{array}$ & $\begin{array}{l}\text { MAZ } \\
\text { MAZ }\end{array}$ & $\begin{array}{l}\text { VAT } \\
\text { VAT }\end{array}$ \\
\hline Delicado & Entremezes & cozido & ave & & VAL & $\mathrm{BN}$ & & VAT \\
\hline Aves recheadas & Entremezes & assado & $\begin{array}{c}\text { ave } \\
\text { quadrúpede }\end{array}$ & $\begin{array}{c}\text { galinha } \\
\text { carneiro } \\
\text { vitela }\end{array}$ & VAL & $\mathrm{BN}$ & MAZ & VAT \\
\hline Sem nome & Entremezes & cozido & ave & galinha & & $\mathrm{BN}$ & MAZ & \\
\hline Geléia de peixe ou carne & Entremezes & cozido & quadrúpede & & VAL & $\mathrm{BN}$ & MAZ & VAT \\
\hline Cisne revestido & Entremezes & assado & ave & cisne & VAL & $\mathrm{BN}$ & & VAT \\
\hline Sálvia fria & Entremezes & cozido & ave & & VAL & $\mathrm{BN}$ & MAZ & VAT \\
\hline Ensopado de leitão & Entremezes & cozido & quadrúpede & leitão & VAL & $\mathrm{BN}$ & MAZ & VAT \\
\hline Caldo de frango & Pratos $\mathrm{p} /$ doentes & cozido & ave & frango & VAL & $\mathrm{BN}$ & MAZ & VAT \\
\hline $\begin{array}{l}\text { Água rosada de capão } \\
\text { ou frango }\end{array}$ & Pratos $\mathrm{p} /$ doentes & cozido & ave & $\begin{array}{l}\text { capão } \\
\text { frango }\end{array}$ & VAL & $\mathrm{BN}$ & MAZ & VAT \\
\hline Manjar branco de capão & Pratos $\mathrm{p} /$ doentes & cozido & ave & capão & VAL & $\mathrm{BN}$ & MAZ & VAT \\
\hline Cuminade de peixe & Pratos $\mathrm{p} /$ doentes & cozido & ave & & & & & VAT \\
\hline Outras sopas menores & $\begin{array}{c}\text { Conhecimento } \\
\text { Geral } \\
\end{array}$ & $\begin{array}{l}\text { cozido } \\
\text { cozido }\end{array}$ & $\begin{array}{l}\text { quadrúpede } \\
\text { quadrúpede }\end{array}$ & $\begin{array}{l}\text { vitela } \\
\text { porco }\end{array}$ & & & & VAT \\
\hline
\end{tabular}

Os açougueiros medievais estavam familiarizados com os diferentes cortes de carne, mas o Viandier não dá qualquer atenção a eles. $\mathrm{O}$ fato de vários cortes serem mencionados no Ménagier deve-se provavelmente ao fato do livro ser destinado a senhoras burguesas, que eram obrigadas a aproveitar da melhor forma possível as carnes de açougue. 
O mundo medieval era fascinado pelos animais e sempre procurou semelhanças entre eles e o homem, criando uma espécie de fauna simbólica. A Tabula exemplorum associa, por exemplo, o usuário ao boi, que nunca descansa ${ }^{84}$.

Em 1344, o rei Pedro de Aragão (1319-1387), nas Ordinations, estabeleceu que ao rei deveria ser servida comida suficiente para oito pessoas; aos príncipes reais, bispos e arcebispos, para seis; outros prelados e cavaleiros à mesa do rei receberiam alimento suficiente para quatro pessoas. $\mathrm{O}$ atentado ao privilégio de classe era severamente punido, pois configurava atentado à ordem social. No século XVI, as leis suntuárias estabeleceram limites, na tentativa de evitar que certos grupos alcançassem um prestígio excessivo. As leis suntuárias estabeleceram limites, na tentativa de evitar que certos grupos alcançassem um prestígio excessivo. Tratou-se de uma tentativa de estabelecer ordem nas transformações sociais que fizeram a burguesia emergir como camada dominante, contra ou em paralelo à nobreza tradicional. Em Veneza, determinava-se que um prato não deveria apresentar mais que três variedades de carne ou frango e proibia-se carnes de animais selvagens. No caso de refeições magras, apenas poderiam ser oferecidos dois assados, dois cozidos e dois fritos, com os respectivos antepastos. Além disso, não se poderia oferecer carne e peixe ao mesmo tempo ${ }^{85}$.

Mas com a expansão da fronteira agrícola e o aumento da produção, apenas o excesso alimentar já não representava mais uma forma de diferenciação. Era cada vez mais necessário um diferencial qualitativo. As carnes consumidas pela nobreza não podiam ser as mesmas da arraia miúda.

No século XI, o consumo de carne tornou-se cada vez mais um privilégio e a oposição entre alimentação vegetal-animal adquiriu um sentido social interno. As tensões geradas pela redução das áreas incultas fizeram aumentar a disputa pela sua exploração. Desse modo, definiram-se de forma cada vez mais clara privilégios associados ao exercício do poder. O rei e aristocracia, em regiões de sólido poder monárquico. Em outras regiões, potentados, bispos, castelães, abades ou cidades.

No século XIII, Salimbe de Parma (1221-1290 d.C.) escreveu que no comer deveria ser dado aos nobres mais do que à gente simples, pois seu estado era superior. Os capitulares régios carolíngios determinavam que os enviados em viagem pelo império fossem providos de alimentos adequados à sua "qualidade de pessoa". E

\footnotetext{
${ }^{84}$ LE GOFF, Jacques. A bolsa e a vida. Tradução Rogerio Silveira Muoio. São Paulo: Editora Brasiliense, 2004, p. 52.

${ }^{85}$ MONTANARI, Massimo. A fome e a abundância: história da alimentação na Europa. Tradução Andréa Doré. São Paulo: Edusc, 2003, p. 108-112.
} 
Alcuíno (735-804) censurou os que consumiam alimentos mais refinados do que a sua qualidade de pessoa exigiria. A relação qualidade do alimento-qualidade de pessoa foi postulada como verdade absoluta ${ }^{86}$.

Se essas ideias afloraram em séculos precedentes, a partir do XIV atingiram uma rigidez singular. Não por acaso, trata-se de um período de reivindicações e revoltas, que levaram à necessidade do reforço dos privilégios e limites aos acessos ao poder. As camadas dominantes fecharam-se cada vez mais sobre si mesmas. A carga simbólica da negação da mesa refinada ao povo adquiriu um caráter fortíssimo. Estabelecia a autorepresentação do poder no momento de discriminação social naquilo que era concreto e tangível.

${ }^{86}$ MONTANARI, Massimo. A fome e a abundância: história da alimentação na Europa. Tradução Andréa Doré. São Paulo: Edusc, 2003, p. 110-115. 


\subsubsection{A relevância do porco}

Celtas e germânicos não possuíam uma "planta de civilização", usando a expressão de Braudel, mas sim um "animal de civilização", o porco. Este resumia os valores produtivos e culturais celtas. É o protagonista de sua mitologia, indispensável ao sustento dos homens, como no poema Porco de Mac Datho. Na mitologia germânica, segundo a Edda, de Snorri, o Grande Porco Saehimnir, compreendido quase como a origem da vida, que todo dia é cozido e está novamente inteiro à noite, alimenta com suas carnes os heróis mortos em batalha. E das tetas da vaca Audhumla jorram quatro rios de leite. A partir do século III, a presença dos bosques aumentou consideravelmente e a criação selvagem de porcos assumiu importância central no sistema alimentar europeu a partir do século $\mathrm{V}^{87}$.

A criação de porcos foi uma das características marcantes da Idade Média, favorecida pela abundância de carvalhos e tradições celtas e germânicas. Quase todas as famílias camponesas possuíam alguns porcos, que tinham papel importante na alimentação. A carne de porco era consumida fresca no inverno e salgada, ou sob a forma de charcutaria, durante todo o ano, além do toucinho ser a gordura comum na maior parte do Ocidente medieval ${ }^{88}$. O porco, do qual eram obtidos os chouriços de sangue, as salsichas, as carnes salgadas e o toucinho, conservados na salgadeira, além das carnes frescas, consumidas rapidamente, constituía uma reserva de carne para vários meses. A matança do porco no início do inverno provia o camponês de carne seca e toucinho para o resto da estação. Já os bovinos eram consumidos pelos camponeses, em geral, apenas quando já estavam velhos demais para a tração. A prioridade dos carneiros era o fornecimento de $1 \tilde{a}^{89}$.

Os camponeses modestos criavam porcos, alimentados de outubro a dezembro com bolotas de carvalho das florestas comunais e soltos durante o restante do tempo em terrenos baldios, campos e ruas das aldeias, onde buscavam qualquer tipo de alimento,

\footnotetext{
${ }^{87}$ MONTANARI, Massimo. A fome e a abundância: história da alimentação na Europa. Tradução Andréa Doré. São Paulo: Edusc, 2003. 22- 26.

${ }^{88}$ RIERA-MELIS, Antoni. Sociedade feudal e alimentação (séculos XII e XIII). In: FLANDRIN, Jean Louis; MONTANARI, Massimo. (Org.). História da alimentação. Tradução Luciano Vieira Machado; Guilherme J. F. Teixeira. São Paulo: Estação Liberdade, 1998, p. 387-408.

${ }^{89}$ LAURIOUX, Bruno. A Idade Média à mesa. Tradução Elsa Andringa. Sintra: Publicações EuropaAmérica, 1989, p. 47-57.
} 
inclusive excrementos. Era comum que o camponês possuísse um só porco, como a maioria dos casos nas pequenas vilas da Provença ${ }^{90}$.

É interessante observar que os romanos consideravam o porco não um animal, mas carne sobre patas, produto limite entre fruges (vegetais) e pecudes (carnes) ${ }^{91}$. Na Idade Média, o porco constitui um caso particular de carne consumida pela população camponesa e preterida pelas demais camadas sociais, o que, de certa forma, continua aproximando esse animal dos vegetais. Além disso é o animal mais próximo dos vegetais na "grande cadeia do ser". Na Itália do final da Idade Média o preço da farinha de frumento era extremamente elevado em relação à carne de porco. ${ }^{92}$.

Mas a caça e o pastoreio nos bosques já eram difíceis para as comunidades a partir do século XIV. As concessões eram raras e podiam ser suspensas a qualquer momento. Os porcos passaram a ser criados no interior das propriedades, em currais.

A carne de porco é mencionada em 15 receitas anteriores ao século XV (em 9 dessas, como alternativa) do Viandier (de um total de 34 receitas que utilizam carne de quadrúpede de criação). As tabelas a seguir demonstram as especificidades das receitas que utilizam carne de porco no Viandier (considerando apenas as anteriores ao século $\mathrm{XV})$.

Tabela 2 - Receitas que utilizam carne de porco no Viandier

\begin{tabular}{|c|c|c|c|c|c|c|c|c|}
\hline RECEITA & SEÇÃO & $\begin{array}{l}\text { MODO DE } \\
\text { PREPARO }\end{array}$ & $\begin{array}{l}\text { TIPO DE } \\
\text { CARNE }\end{array}$ & PARTE & \multicolumn{4}{|c|}{$\begin{array}{l}\text { CONSTANTE NOS } \\
\text { MANUSCRITOS }\end{array}$} \\
\hline Fervura de carne gorda & Sopas gordas & cozido & $\begin{array}{c}\text { vaca } \\
\text { porco } \\
\text { carneiro }\end{array}$ & & & $\mathrm{BN}$ & MAZ & VAT \\
\hline Carnes entremeadas & Sopas gordas & cozido & & & VAL & $\mathrm{BN}$ & MAZ & VAT \\
\hline Caldo quente de porco & Sopas gordas & cozido & porco & tripa & VAL & $\mathrm{BN}$ & MAZ & VAT \\
\hline Caldo de canela & Sopas gordas & $\begin{array}{l}\text { cozido } \\
\text { cozido }\end{array}$ & & & VAL & $\mathrm{BN}$ & MAZ & VAT \\
\hline Caldo ruivo & Sopas gordas & $\begin{array}{l}\text { cozido } \\
\text { cozido } \\
\end{array}$ & & & VAL & $\mathrm{BN}$ & MAZ & VAT \\
\hline Vísceras de porco & Sopas gordas & cozido & porco & vísceras & VAL & $\mathrm{BN}$ & MAZ & VAT \\
\hline Rápido caldo inglês & Sopas gordas & cozido & porco & & VAL & $\mathrm{BN}$ & MAZ & VAT \\
\hline Caldo de agraço & Sopas gordas & cozido & & & VAL & $\mathrm{BN}$ & & VAT \\
\hline
\end{tabular}

\footnotetext{
${ }^{90}$ STOUFF, Louis. Ravitaillement et alimentation em Provence aux XIV e XVe siècles. Paris: Mouton, 1970, p. 116-123.

${ }^{91}$ DUPONT, Florence. Gramática da alimentação e das refeições romanas. In: FLANDRIN, Jean Louis ; MONTANARI, Massimo. (Org.). História da alimentação. Tradução Luciano Vieira Machado; Guilherme J. F. Teixeira. São Paulo: Estação Liberdade, 1998, p. 199-216.

92 GRIECO, Allen F. Alimentação e classes sociais no fím da Idade Média e na Renascença. In: FLANDRIN, Jean Louis; MONTANARI, Massimo. (Org.). História da alimentação. Tradução Luciano Vieira Machado; Guilherme J. F. Teixeira. São Paulo: Estação Liberdade, 1998, p. 466-477.
} 


\begin{tabular}{|c|c|c|c|c|c|c|c|c|}
\hline Caldo amarelo-verde & Sopas gordas & cozido & & & VAL & $\mathrm{BN}$ & MAZ & VAT \\
\hline Rappé & Sopas gordas & cozido & & & VAL & $\mathrm{BN}$ & MAZ & VAT \\
\hline Porco assado & $\begin{array}{l}\text { Carnes } \\
\text { Assadas }\end{array}$ & $\begin{array}{l}\text { assado } \\
\text { empada }\end{array}$ & $\begin{array}{l}\text { porco } \\
\text { porco }\end{array}$ & & VAL & $\mathrm{BN}$ & MAZ & VAT \\
\hline Leitão recheado & $\begin{array}{l}\text { Carnes } \\
\text { Assadas }\end{array}$ & assado & leitão & & VAL & $\mathrm{BN}$ & MAZ & VAT \\
\hline Geléia de peixe ou carne & Entremezes & cozido & & & VAL & $\mathrm{BN}$ & MAZ & VAT \\
\hline Ensopado de leitão & Entremezes & cozido & leitão & $\begin{array}{l}\text { pés } \\
\text { rabo } \\
\text { orelha } \\
\text { focinho }\end{array}$ & VAL & $\mathrm{BN}$ & MAZ & VAT \\
\hline Outras sopas menores & $\begin{array}{c}\text { Conhecimento } \\
\text { Geral } \\
\end{array}$ & $\begin{array}{l}\text { cozido } \\
\text { cozido } \\
\end{array}$ & $\begin{array}{l}\text { vitela } \\
\text { porco } \\
\end{array}$ & $\begin{array}{l}\text { tripa e } \\
\text { miúdos }\end{array}$ & & & & VAT \\
\hline
\end{tabular}

O bacon também era muito usado na cozinha nobiliárquica. No Viandier, ele é especificamente mencionado em nada menos que 31 receitas (anteriores ao século XV), detalhadas na tabela abaixo.

Tabela 3 - Receitas que utilizam bacon no Viandier

\begin{tabular}{|c|c|c|c|c|c|c|c|c|}
\hline RECEITA & SEÇÃO & $\begin{array}{c}\text { MODO } \\
\text { DE } \\
\text { PREPARO }\end{array}$ & $\begin{array}{l}\text { TIPO DE } \\
\text { CARNE }\end{array}$ & ESPÉCIE & \multicolumn{4}{|c|}{$\begin{array}{c}\text { CONSTANTE NOS } \\
\text { MANUSCRITOS }\end{array}$} \\
\hline Retalhado de carneiro & Sopas gordas & Cozido & quadrúpede & carneiro & & $\mathrm{BN}$ & MAZ & VAT \\
\hline $\begin{array}{l}\text { Capões ou vitela } \\
\text { com ervas }\end{array}$ & Sopas gordas & $\begin{array}{l}\text { Cozido } \\
\text { Cozido }\end{array}$ & $\begin{array}{c}\text { ave } \\
\text { quadrúpede }\end{array}$ & $\begin{array}{l}\text { capão } \\
\text { vitela }\end{array}$ & & $\mathrm{BN}$ & & VAT \\
\hline Caldo quente de porco & Sopas gordas & Cozido & quadrúpede & porco & VAL & $\mathrm{BN}$ & MAZ & VAT \\
\hline Cretonada de ervilhas & Sopas gordas & Cozido & ave & galinha & VAL & $\mathrm{BN}$ & MAZ & VAT \\
\hline Cretonada de favas & Sopas gordas & Cozido & ave & galinha & & $\mathrm{BN}$ & MAZ & VAT \\
\hline Cuminade de aves & Sopas gordas & Cozido & ave & & VAL & $\mathrm{BN}$ & MAZ & VAT \\
\hline $\begin{array}{l}\text { Cuminade de } \\
\text { amêndoas }\end{array}$ & Sopas gordas & Cozido & ave & & VAL & $\mathrm{BN}$ & & VAT \\
\hline Caldo de canela & Sopas gordas & $\begin{array}{l}\text { Cozido } \\
\text { Cozido }\end{array}$ & $\begin{array}{c}\text { ave } \\
\text { quadrúpede }\end{array}$ & & VAL & $\mathrm{BN}$ & MAZ & VAT \\
\hline Caldo georgié & Sopas gordas & Cozido & ave & doméstica & VAL & $\mathrm{BN}$ & MAZ & VAT \\
\hline Caldo ruivo & Sopas gordas & $\begin{array}{l}\text { Cozido } \\
\text { Cozido }\end{array}$ & $\begin{array}{c}\text { quadrúpede } \\
\text { ave }\end{array}$ & & VAL & $\mathrm{BN}$ & MAZ & VAT \\
\hline Vísceras de porco & Sopas gordas & Cozido & & & VAL & $\mathrm{BN}$ & MAZ & VAT \\
\hline Molho de pássaros & Sopas gordas & Cozido & ave & $\begin{array}{l}\text { pássaros } \\
\text { pequenos }\end{array}$ & VAL & $\mathrm{BN}$ & MAZ & VAT \\
\hline $\begin{array}{l}\text { Caldo branco de } \\
\text { capões }\end{array}$ & Sopas gordas & Cozido & ave & capão & VAL & $\mathrm{BN}$ & MAZ & VAT \\
\hline $\begin{array}{l}\text { Aferventado de lebres } \\
\text { ou coelhos }\end{array}$ & Sopas gordas & $\begin{array}{l}\text { Cozido } \\
\text { Cozido }\end{array}$ & $\begin{array}{l}\text { quadrúpede } \\
\text { quadrúpede }\end{array}$ & $\begin{array}{l}\text { lebre } \\
\text { coelho }\end{array}$ & VAL & $\mathrm{BN}$ & MAZ & VAT \\
\hline Aferventado de capões & Sopas gordas & Cozido & ave & capão & VAL & $\mathrm{BN}$ & MAZ & VAT \\
\hline
\end{tabular}




\begin{tabular}{|c|c|c|c|c|c|c|c|c|}
\hline $\begin{array}{l}\text { Caldo alemão de } \\
\text { coelhos } \\
\text { ou aves }\end{array}$ & Sopas gordas & $\begin{array}{l}\text { Cozido } \\
\text { Cozido } \\
\end{array}$ & $\begin{array}{c}\text { quadrúpede } \\
\text { ave } \\
\end{array}$ & coelho & VAL & $\mathrm{BN}$ & MAZ & VAT \\
\hline Mexido de aves & Sopas gordas & Cozido & ave & & VAL & $\mathrm{BN}$ & MAZ & VAT \\
\hline Caldo de agraço & Sopas gordas & $\begin{array}{l}\text { Cozido } \\
\text { Cozido } \\
\end{array}$ & $\begin{array}{c}\text { quadrúpede } \\
\text { ave }\end{array}$ & & VAL & $\mathrm{BN}$ & & VAT \\
\hline Caldo amarelo-verde & Sopas gordas & $\begin{array}{l}\text { Cozido } \\
\text { Cozido } \\
\end{array}$ & $\begin{array}{c}\text { quadrúpede } \\
\text { ave } \\
\end{array}$ & & VAL & $\mathrm{BN}$ & MAZ & VAT \\
\hline Rappé & Sopas gordas & $\begin{array}{l}\text { Cozido } \\
\text { Cozido } \\
\end{array}$ & $\begin{array}{c}\text { quadrúpede } \\
\text { ave }\end{array}$ & & VAL & $\mathrm{BN}$ & MAZ & VAT \\
\hline Vitela assada & $\begin{array}{c}\text { Carnes } \\
\text { Assadas } \\
\end{array}$ & empada & quadrúpede & vitela & & $\mathrm{BN}$ & MAZ & VAT \\
\hline Desfiado de bezerro & $\begin{array}{c}\text { Carnes } \\
\text { Assadas }\end{array}$ & Fritura & quadrúpede & bezerro & VAL & $\mathrm{BN}$ & MAZ & VAT \\
\hline $\begin{array}{l}\text { Cabras novas, } \\
\text { cordeiros }\end{array}$ & $\begin{array}{l}\text { Carnes } \\
\text { Assadas }\end{array}$ & Assado & $\begin{array}{l}\text { quadrúpede } \\
\text { quadrúpede }\end{array}$ & $\begin{array}{c}\text { cordeiro } \\
\text { cabra }\end{array}$ & VAL & $\mathrm{BN}$ & MAZ & VAT \\
\hline Galinhas assadas & $\begin{array}{l}\text { Carnes } \\
\text { Assadas }\end{array}$ & $\begin{array}{l}\text { Assado } \\
\text { empada }\end{array}$ & $\begin{array}{l}\text { ave } \\
\text { ave }\end{array}$ & $\begin{array}{l}\text { galinha } \\
\text { galinha }\end{array}$ & VAL & $\mathrm{BN}$ & MAZ & VAT \\
\hline Coelhos assados & $\begin{array}{l}\text { Carnes } \\
\text { Assadas }\end{array}$ & $\begin{array}{l}\text { Assado } \\
\text { empada }\end{array}$ & $\begin{array}{l}\text { quadrúpede } \\
\text { quadrúpede }\end{array}$ & $\begin{array}{l}\text { coelho } \\
\text { coelho }\end{array}$ & VAL & $\mathrm{BN}$ & MAZ & VAT \\
\hline Lebres assadas & $\begin{array}{c}\text { Carnes } \\
\text { Assadas }\end{array}$ & empada & quadrúpede & lebre & VAL & $\mathrm{BN}$ & MAZ & VAT \\
\hline Pássaros pequenos & $\begin{array}{c}\text { Carnes } \\
\text { Assadas }\end{array}$ & empada & ave & $\begin{array}{l}\text { pássaros } \\
\text { pequenos }\end{array}$ & VAL & $\mathrm{BN}$ & MAZ & VAT \\
\hline Perdiz & $\begin{array}{c}\text { Carnes } \\
\text { Assadas }\end{array}$ & empada & ave & perdiz & VAL & $\mathrm{BN}$ & MAZ & VAT \\
\hline Falso grenon & Entremezes & $\begin{array}{l}\text { Cozido } \\
\text { Cozido } \\
\end{array}$ & $\begin{array}{c}\text { ave } \\
\text { quadrúpede } \\
\end{array}$ & $\begin{array}{c}\text { ave doméstica } \\
\text { vitela }\end{array}$ & VAL & $\mathrm{BN}$ & MAZ & VAT \\
\hline Sem nome & Entremezes & Cozido & ave & galinha & & $\mathrm{BN}$ & MAZ & \\
\hline Cuminade de peixe & $\begin{array}{c}\text { Pratos } \mathrm{p} / \\
\text { doentes }\end{array}$ & Cozido & ave & & & & & VAT \\
\hline
\end{tabular}

$\mathrm{Na}$ Idade Média o porco era considerado o animal mais aparentado ao homem e o consumo de sua carne simbolizava a comunhão do homem com o homem. A Cocanha é a terra do porco e Hilário Franco Júnior aborda a possibilidade literária da proposição da homologia porco/divindade pelo fabliau francês, e o duplo canibalismo, sexual e alimentar, que tornaria operacionalizável o panteísmo cocaniano, a partir da analogia entre suíno, humano e divino. No texto anticlerical e subversivo o porco representaria a relação com a terra, confundida com Deus no pensamento panteísta ${ }^{93}$.

\footnotetext{
${ }^{93}$ FRANCO JR, Hilário. Os três dedos de Adão: ensaios de mitologia medieval. São Paulo: Edusp, 2010, p. $243-270$.
} 


\subsection{Produção e circulação}

\subsubsection{A caça, a criação e os ofícios}

A caça estava ligada diretamente à idéia de força e poder e era a única atividade da nobreza, além da guerra,exprimindo a cultura da força e violência consagrada no uso das armas. As carnes expressavam a ligação entre noções de consumo e força física, que aparecia em todos os aspectos da cultura medieval e eram percebidas como meio para adquirir força e poder. O direito de consumi-las estava legitimado pelo valor militar ${ }^{94}$.

$\mathrm{Na}$ Antiguidade romana, a caça não estava ligada a uma categoria social particular, o que foi refletido nas "leis bárbaras". A criação das florestas pelos reis (século VII), talvez fosse uma compensação simbólica à ausência de autoridade verdadeira.

Os Carolíngios ampliaram as forestae e os Otonianos começaram a ceder aos aristocratas o direito de afforestatio. Desde o século XII há testemunhos de métodos extremamente cruéis exercidos para reprimir o desrespeito a esse privilégio. $\mathrm{Na}$ Renânia, no século X, o monge Regino de Prüm, a serviço do arcebispo de Trier, escreveu o trabalho intitulado De ecclesiasticis disciplinis, no qual consta um questionário para avaliação da conduta moral dos clérigos da região. Uma das perguntas buscava investigar se os padres eram dados a jogos com cães e pássaros ${ }^{95}$.

No século XIII, o uso da temática da caça mística manifestou a reconciliação da Igreja com essa prática (antes considerada incompatível com o clero e de conotação pagã). A Igreja já não sentia tanta rivalidade em relação à aristocracia laica e seus ritos próprios foram incorporados aos eclesiásticos como reforço ou complemento ${ }^{96}$.

A nobreza praticava a caça com cães ou com pássaros, e ambas apresentavam significado simbólico.

\footnotetext{
${ }^{94}$ MONTANARI, Massimo. Os camponeses, os guerreiros e os sacerdotes: imagem da sociedade e estilos de alimentação. In: FLANDRIN, Jean Louis; MONTANARI, Massimo. (Org.). História da alimentação. Tradução Luciano Vieira Machado; Guilherme J. F. Teixeira. São Paulo: Estação Liberdade, 1998, p. 292-309.

95 REGINO DE PRÜM. De ecclesiasticis disciplinis. In: MIGNE PATROLOGIA LATINA. Disponível em: <http://www.documentacatholicaomnia.eu/30_10_0882-0915-_Regino_Prumiensis_Abbas.html> Acesso em: 05 set. 2012.

${ }^{96}$ GUERREAU, Alain. Caça. Tradução Vivian Coutinho de Almeida In: LE GOFF, Jacques; SCHMITT, Jean-Claude. (Org.). Dicionário temático do Ocidente Medieval. São Paulo: Edusc, v. 1, 2006, p.139-151.
} 
A definição do tipo de caça implicava diretamente no tipo de espaço em que ela ocorreria. A caça com cães acontecia na floresta (espaço aberto) e consistia em seguir um animal com a matilha até que ele, exausto, parava e enfrentava os cães, que o abatiam nesse momento. Visava-se principalmente o cervo, o gamo e o cabrito, secundariamente o javali (o urso era raro). Animais nocivos, tais como lobo e raposa, eram pouco atraentes. Já as lebres eram consideradas medíocres. Essa modalidade foi adotada pela aristocracia, no século X, e se generalizou durante os séculos XII e XIII, o que levou à interdição da caça aos camponeses. A caça com pássaros era praticada em espaços "interiores", eventualmente cultivados, e era uma atividade permitida às mulheres. Os cães denunciavam o animal e aves treinadas o abatiam. Já a caça com pássaros em uma floresta era considerada uma atividade vil e degradante ${ }^{97}$.

Os manuais de caça, do final da Idade Média, dedicavam grande atenção aos cães e falcões e, por extensão, aos monteiros e falcoeiros, que faziam parte do círculo pessoal dos senhores. Durante o período medieval, aprimoraram-se raças caninas caçadoras (embora "cão" configurasse insulto grave, sinônimo de herege ou infiel). Os falcões adestrados eram presentes de grande valor.

Essa organização do espaço era carregada de conotações sexuais. O par cãopássaro representava o par homem-mulher. $\mathrm{O}$ valor do animal caçado remetia ao valor do caçador. O cervo ou o javali representavam o cavaleiro, enquanto as presas das aves de rapina (grou, ganso selvagem, coelho) tinham conotação feminina, representavam a dama. Usava-se um animal doméstico para caçar em espaço selvagem e um animal selvagem adestrado no espaço cultivado.

Corresponde a essa estrutura um eixo de representação no qual opunham-se o interior-homem-Deus e o exterior-mulher-Diabo. $\mathrm{Na}$ iconografia profana o cão era emblemático da dama e o falcão ou gavião era atributo do cavaleiro. Sabe-se que os ritos de dominação apresentam-se quase sempre como ritos de inversão. A caça bipartida era o grande rito de dominação da aristocracia laica, que tratava, ao mesmo tempo, da identificação do espaço. No sistema cortês-cavalheiresco, a relação homemdama personificava a relação cavaleiro-senhor, tendo em vista a dependência selada pela fé, imprescindível para o ordenamento da sociedade medieval ${ }^{98}$.

\footnotetext{
${ }^{97}$ GUERREAU, Alain. Caça. Tradução Vivian Coutinho de Almeida In: LE GOFF, Jacques; SCHMITT, Jean-Claude. (Org.). Dicionário temático do Ocidente Medieval. São Paulo: Edusc, v. 1, 2006, p.139 et seq.

${ }^{98}$ Ibidem, p. 139 et seq.
} 
Na Inglaterra o rei reservou para si o direito à caça "maior", cervos e animais de grande porte, e aos senhores laicos, a caça menor ${ }^{99}$.

A análise de ossos, realizada em áreas de lixo senhorial, demonstrou que a aristocracia não recorria à caça para obter carne, uma vez que a proporção encontrada não chega a 5\%. A análise de contas palacianas confirma esse dado, pois evidencia que a maior parte da carne consumida era comprada de açougues. Anita Guerreau-Jalabert demonstrou que a presença constante da caça nas mesas senhoriais apresentava, na verdade, codificação simbólica ${ }^{100}$.

Novamente, analisando as 170 receitas do Viandier anteriores ao século $\mathrm{XV}$, constatamos que das 71 receitas que apresentavam carne entre seus ingredientes, 23 requeriam carne de caça, sendo 8 de quadrúpede e 15 de ave.

A tabela a seguir demonstra as especificidades das receitas que utilizam carne de caça no Viandier (considerando apenas as anteriores ao século XV).

Tabela 4 - Receitas que utilizam carne de caça no Viandier

\begin{tabular}{|c|c|c|c|c|c|c|c|c|}
\hline RECEITA & SEÇÃO & $\begin{array}{l}\text { MODO DE } \\
\text { PREPARO }\end{array}$ & $\begin{array}{l}\text { TIPO DE } \\
\text { CARNE }\end{array}$ & ESPÉCIE & \multicolumn{4}{|c|}{$\begin{array}{c}\text { CONSTANTE NOS } \\
\text { MANUSCRITOS }\end{array}$} \\
\hline $\begin{array}{l}\text { Veadada de veado } \\
\text { fresco }\end{array}$ & Sopas gordas & $\begin{array}{l}\text { cozido } \\
\text { empada } \\
\end{array}$ & quadrúpede & veado & VAL & & MAZ & VAT \\
\hline Javali & Sopas gordas & $\begin{array}{l}\text { cozido } \\
\text { cozido }\end{array}$ & $\begin{array}{l}\text { quadrúpede } \\
\text { quadrúpede }\end{array}$ & $\begin{array}{l}\text { javali } \\
\text { veado }\end{array}$ & VAL & $\mathrm{BN}$ & MAZ & VAT \\
\hline Cabra selvagem & Sopas gordas & $\begin{array}{l}\text { cozido } \\
\text { empada } \\
\end{array}$ & quadrúpede & $\begin{array}{c}\text { cabra } \\
\text { selvagem }\end{array}$ & VAL & $\mathrm{BN}$ & MAZ & \\
\hline Molho de pássaros & Sopas gordas & cozido & ave & & VAL & $\mathrm{BN}$ & MAZ & VAT \\
\hline $\begin{array}{l}\text { Aferventado de lebres } \\
\text { ou coelhos }\end{array}$ & Sopas gordas & $\begin{array}{l}\text { cozido } \\
\text { cozido } \\
\end{array}$ & $\begin{array}{l}\text { quadrúpede } \\
\text { quadrúpede }\end{array}$ & $\begin{array}{l}\text { lebre } \\
\text { coelho }\end{array}$ & VAL & $\mathrm{BN}$ & MAZ & VAT \\
\hline Guisado de lebres & Sopas gordas & cozido & quadrúpede & lebre & VAL & $\mathrm{BN}$ & MAZ & VAT \\
\hline
\end{tabular}

${ }^{99}$ MONTANARI, Massimo. A fome e a abundância: história da alimentação na Europa. Tradução Andréa Doré. São Paulo: Edusc, 2003, p. 63.

${ }_{100}$ GUERREAU-JALABER, Anita. Aliments symboliques et symbolique de la table dans les romans arthuriens .Annales: ESC, 47, 1992, p.561-94. 


\begin{tabular}{|c|c|c|c|c|c|c|c|c|}
\hline $\begin{array}{l}\text { Lebres assadas } \\
\text { Atoleiro de javali } \\
\text { fresco }\end{array}$ & $\begin{array}{c}\text { Carnes } \\
\text { Assadas } \\
\text { Carnes } \\
\text { Assadas }\end{array}$ & $\begin{array}{l}\text { assado } \\
\text { empada } \\
\text { assado }\end{array}$ & $\begin{array}{l}\text { quadrúpede } \\
\text { quadrúpede } \\
\text { quadrúpede }\end{array}$ & $\begin{array}{l}\text { lebre } \\
\text { lebre } \\
\text { javali }\end{array}$ & $\begin{array}{l}\text { VAL } \\
\text { VAL }\end{array}$ & $\begin{array}{l}\mathrm{BN} \\
\mathrm{BN}\end{array}$ & $\begin{array}{l}\text { MAZ } \\
\text { MAZ }\end{array}$ & $\begin{array}{l}\text { VAT } \\
\text { VAT }\end{array}$ \\
\hline $\begin{array}{l}\text { Todos os veados } \\
\text { frescos }\end{array}$ & $\begin{array}{c}\text { Carnes } \\
\text { Assadas }\end{array}$ & assado & quadrúpede & veado & & $\mathrm{BN}$ & MAZ & VAT \\
\hline Pássaros pequenos & $\begin{array}{c}\text { Carnes } \\
\text { Assadas }\end{array}$ & $\begin{array}{l}\text { assado } \\
\text { empada } \\
\end{array}$ & $\begin{array}{l}\text { ave } \\
\text { ave } \\
\end{array}$ & $\begin{array}{l}\text { pássaros } \\
\text { pequenos } \\
\text { pássaros } \\
\text { pequenos }\end{array}$ & VAL & $\mathrm{BN}$ & MAZ & VAT \\
\hline $\begin{array}{l}\text { Carambolas e } \\
\text { galinholas }\end{array}$ & $\begin{array}{l}\text { Carnes } \\
\text { Assadas }\end{array}$ & $\begin{array}{l}\text { assado } \\
\text { empada }\end{array}$ & $\begin{array}{l}\text { ave } \\
\text { ave }\end{array}$ & $\begin{array}{c}\text { carambola } \\
\text { galinhola } \\
\text { carambola } \\
\text { galinhola }\end{array}$ & & $\mathrm{BN}$ & & VAT \\
\hline Perdiz & $\begin{array}{l}\text { Carnes } \\
\text { Assadas }\end{array}$ & $\begin{array}{l}\text { assado } \\
\text { empada }\end{array}$ & $\begin{array}{l}\text { ave } \\
\text { ave }\end{array}$ & $\begin{array}{l}\text { perdiz } \\
\text { perdiz }\end{array}$ & VAL & $\mathrm{BN}$ & MAZ & VAT \\
\hline Rolas & $\begin{array}{l}\text { Carnes } \\
\text { Assadas }\end{array}$ & $\begin{array}{l}\text { assado } \\
\text { empada }\end{array}$ & $\begin{array}{l}\text { ave } \\
\text { ave }\end{array}$ & $\begin{array}{l}\text { rola } \\
\text { rola }\end{array}$ & & $\mathrm{BN}$ & & VAT \\
\hline Faisões & $\begin{array}{l}\text { Carnes } \\
\text { Assadas } \\
\end{array}$ & assado & ave & faisão & VAL & $\mathrm{BN}$ & MAZ & VAT \\
\hline Cegonhas & $\begin{array}{c}\text { Carnes } \\
\text { Assadas }\end{array}$ & assado & ave & cegonha & VAL & $\mathrm{BN}$ & MAZ & VAT \\
\hline Garças-reais & $\begin{array}{c}\text { Carnes } \\
\text { Assadas } \\
\end{array}$ & assado & ave & garça & VAL & $\mathrm{BN}$ & MAZ & VAT \\
\hline Pato-real do rio & $\begin{array}{l}\text { Carnes } \\
\text { Assadas } \\
\end{array}$ & assado & ave & pato do rio & $\mathrm{VAL}$ & $\mathrm{BN}$ & MAZ & VAT \\
\hline $\begin{array}{l}\text { Abetardos, gansos e } \\
\text { grous }\end{array}$ & $\begin{array}{c}\text { Carnes } \\
\text { Assadas }\end{array}$ & assado & ave & $\begin{array}{l}\text { abetardo } \\
\text { ganso } \\
\text { selvagem } \\
\text { grou }\end{array}$ & VAL & $\mathrm{BN}$ & MAZ & VAT \\
\hline Alcaravões & $\begin{array}{l}\text { Carnes } \\
\text { Assadas } \\
\end{array}$ & assado & ave & alcavarão & & $\mathrm{BN}$ & & VAT \\
\hline Cormorões & $\begin{array}{l}\text { Carnes } \\
\text { Assadas } \\
\end{array}$ & assado & ave & cormorão & VAL & $\mathrm{BN}$ & MAZ & VAT \\
\hline Colhereiros & $\begin{array}{l}\text { Carnes } \\
\text { Assadas }\end{array}$ & assado & ave & colheiro & & & & VAT \\
\hline Marrequinho & $\begin{array}{c}\text { Carnes } \\
\text { Assadas } \\
\end{array}$ & assado & ave & marrequinho & & & & VAT \\
\hline Cisne revestido & Entremezes & assado & ave & cisne & VAL & $\mathrm{BN}$ & & VAT \\
\hline
\end{tabular}

O estilo de vida dos "bárbaros" estava estreitamente ligado à cultura da floresta e exploração de recursos, reabilitados na Idade Média. Além da caça, a criação de animais em semiliberdade, principalmente porcos, adquiriu enorme importância. Os bosques 
eram espaços de produção, medidos em "porcos" "101. Os cabritos, cordeiros, vitelos, os melhores carneiros, em suma, a carne que podia ser vendida, eram abatidos, em geral, nas cidades. Os animais velhos e de menor valor, sobretudo porcos, eram consumidos pelos próprios criadores ${ }^{102}$.

Animais que hoje são considerados selvagens eram criados como animais domésticos. Os lombardos, por exemplo, criavam cervos em volta das casas. Algumas espécies consideradas domésticas eram caçadas em estado natural, como foi o caso do auroque, presente nas florestas europeias até o século X. E os porcos, criados soltos nos bosques, pouco se diferenciavam dos javalis selvagens ${ }^{103}$.

Até o século XIII, o porco salgado era a carne mais consumida no campo ou na cidade. Mas a criação de bovinos do XIV destinou-se principalmente ao abastecimento urbano. Para uma família camponesa o abate de um boi não compensava, o que tornou a carne bovina símbolo do dinamismo comercial, em contraponto à carne suína, símbolo da economia familiar; do bosque em contraponto à criação organizada; do campo em contraponto à cidade. Os citadinos gostavam da distinção que o consumo da carne mais cara do mercado, boi, bezerro, vitelo proporcionava. Ovelhas para quem não podia ${ }^{104}$.

Nos locais onde existiam as antigas florestas cresceram prados, mais adequados às ovelhas que aos porcos. Das ovelhas necessitava a produção lanífera, e sua carne tornou-se moda nas cidades no século XIV. Sinalizavam distinção e emancipação dos hábitos camponeses, em oposição ao porco, que declinou nos mercados urbanos. ${ }^{105}$.

Das 28 receitas do Viandier (anteriores ao século XV), que utilizam carne de quadrúpede de criação, 8 especificam bovinos, 8 suínos e 5 ovinos. Essas carnes são apresentadas como alternativas em 6 receitas. E apenas uma das receitas que especificam a carne bovina admite um animal adulto; as outras 5 tratam de carne de vitela ou bezerro. O coelho é especificado em 4 receitas (em duas delas como alternativa) e a cabra, em apenas uma (também como alternativa).

\footnotetext{
101 MONTANARI, Massimo. Os camponeses, os guerreiros e os sacerdotes: imagem da sociedade e estilos de alimentação. In: FLANDRIN, Jean Louis; MONTANARI, Massimo. (Org.). História da alimentação. Tradução Luciano Vieira Machado; Guilherme J. F. Teixeira. São Paulo: Estação Liberdade, 1998, p. 178-281

${ }^{102}$ CORTONESI, Alfio. Cultura de subsistência e mercado: a alimentação rural e urbana na baixa Idade Média. In: FLANDRIN, Jean Louis: MONTANARI, Massimo. (Org.). História da alimentação. Tradução Luciano Vieira Machado; Guilherme J. F. Teixeira. São Paulo: Estação Liberdade, 1998, p. 419.

${ }^{103}$ MONTANARI, op. cit, p. 51.

${ }^{104}$ Idem, 2003, p. 100.

${ }^{105}$ Ibidem, p. 101.
} 
A tabela a seguir apresenta especificidades das receitas anteriores ao século XV que utilizam carne de criação no Viandier.

Tabela 5 - Receitas que utilizam carne de criação no Viandier

\begin{tabular}{|c|c|c|c|c|c|c|c|c|}
\hline RECEITA & SEÇÃO & $\begin{array}{l}\text { MODO DE } \\
\text { PREPARO }\end{array}$ & $\begin{array}{l}\text { TIPO DE } \\
\text { CARNE }\end{array}$ & ESPÉCIE & \multicolumn{4}{|c|}{$\begin{array}{c}\text { CONSTANTE NOS } \\
\text { MANUSCRITOS }\end{array}$} \\
\hline Fervura de carne gorda & Sopas gordas & cozido & quadrúpede & $\begin{array}{c}\text { vaca } \\
\text { porco } \\
\text { carneiro }\end{array}$ & & $\mathrm{BN}$ & MAZ & VAT \\
\hline Retalhado de carneiro & Sopas gordas & cozido & quadrúpede & carneiro & & $\mathrm{BN}$ & MAZ & VAT \\
\hline Carnes entremeadas & Sopas gordas & cozido & quadrúpede & & VAL & $\mathrm{BN}$ & MAZ & VAT \\
\hline Capões ou vitela com ervas & Sopas gordas & $\begin{array}{l}\text { cozido } \\
\text { cozido }\end{array}$ & $\begin{array}{c}\text { ave } \\
\text { quadrúpede }\end{array}$ & $\begin{array}{l}\text { capão } \\
\text { vitela }\end{array}$ & & $\mathrm{BN}$ & & VAT \\
\hline Caldo quente de porco & Sopas gordas & cozido & quadrúpede & porco & VAL & $\mathrm{BN}$ & MAZ & VAT \\
\hline Cretonada de ervilhas & Sopas gordas & cozido & ave & galinha & VAL & $\mathrm{BN}$ & MAZ & VAT \\
\hline Cretonada de favas & Sopas gordas & cozido & ave & galinha & & $\mathrm{BN}$ & MAZ & VAT \\
\hline Cuminade de aves & Sopas gordas & cozido & ave & & VAL & $\mathrm{BN}$ & MAZ & VAT \\
\hline Cuminade de amêndoas & Sopas gordas & cozido & ave & & VAL & $\mathrm{BN}$ & & VAT \\
\hline Caldo de canela & Sopas gordas & $\begin{array}{l}\text { cozido } \\
\text { cozido } \\
\end{array}$ & $\begin{array}{c}\text { ave } \\
\text { quadrúpede }\end{array}$ & & VAL & $\mathrm{BN}$ & MAZ & VAT \\
\hline Caldo georgié & Sopas gordas & cozido & ave & doméstica & VAL & $\mathrm{BN}$ & MAZ & VAT \\
\hline Caldo ruivo & Sopas gordas & $\begin{array}{l}\text { cozido } \\
\text { cozido } \\
\end{array}$ & $\begin{array}{c}\text { quadrúpede } \\
\text { ave } \\
\end{array}$ & & VAL & $\mathrm{BN}$ & MAZ & VAT \\
\hline Vísceras de porco & Sopas gordas & cozido & quadrúpede & porco & VAL & $\mathrm{BN}$ & MAZ & VAT \\
\hline Molho de pássaros & Sopas gordas & cozido & ave & & VAL & $\mathrm{BN}$ & MAZ & VAT \\
\hline Caldo branco de capões & Sopas gordas & cozido & ave & capão & VAL & $\mathrm{BN}$ & MAZ & VAT \\
\hline $\begin{array}{l}\text { Aferventado de lebres } \\
\text { ou coelhos }\end{array}$ & Sopas gordas & $\begin{array}{l}\text { cozido } \\
\text { cozido }\end{array}$ & $\begin{array}{l}\text { quadrúpede } \\
\text { quadrúpede }\end{array}$ & $\begin{array}{l}\text { lebre } \\
\text { coelho }\end{array}$ & VAL & $\mathrm{BN}$ & MAZ & VAT \\
\hline Aferventado de capões & Sopas gordas & cozido & ave & capão & VAL & $\mathrm{BN}$ & MAZ & VAT \\
\hline $\begin{array}{l}\text { Caldo alemão de coelhos } \\
\text { ou aves }\end{array}$ & Sopas gordas & $\begin{array}{l}\text { cozido } \\
\text { cozido } \\
\end{array}$ & $\begin{array}{c}\text { quadrúpede } \\
\text { ave } \\
\end{array}$ & coelho & VAL & $\mathrm{BN}$ & MAZ & VAT \\
\hline Mexido de aves & Sopas gordas & cozido & ave & & VAL & $\mathrm{BN}$ & MAZ & VAT \\
\hline Rápido caldo inglês & Sopas gordas & cozido & quadrúpede & porco & VAL & $\mathrm{BN}$ & MAZ & VAT \\
\hline Caldo de agraço & Sopas gordas & $\begin{array}{l}\text { cozido } \\
\text { cozido }\end{array}$ & $\begin{array}{c}\text { quadrúpede } \\
\text { ave } \\
\end{array}$ & & VAL & $\mathrm{BN}$ & & VAT \\
\hline Caldo amarelo-verde & Sopas gordas & $\begin{array}{l}\text { cozido } \\
\text { cozido } \\
\end{array}$ & $\begin{array}{c}\text { quadrúpede } \\
\text { ave } \\
\end{array}$ & & VAL & $\mathrm{BN}$ & MAZ & VAT \\
\hline Rappé & Sopas gordas & $\begin{array}{l}\text { cozido } \\
\text { cozido } \\
\end{array}$ & $\begin{array}{c}\text { quadrúpede } \\
\text { ave } \\
\end{array}$ & & VAL & $\mathrm{BN}$ & MAZ & VAT \\
\hline Guisado de vitela & Sopas gordas & cozido & quadrúpede & vitela & VAL & $\mathrm{BN}$ & MAZ & VAT \\
\hline Guisado de coelhos & Sopas gordas & cozido & quadrúpede & coelho & & $\mathrm{BN}$ & & VAT \\
\hline
\end{tabular}




\begin{tabular}{|c|c|c|c|c|c|c|c|c|}
\hline Porco assado & Carnes Assadas & $\begin{array}{l}\text { assado } \\
\text { empada }\end{array}$ & $\begin{array}{l}\text { quadrúpede } \\
\text { quadrúpede }\end{array}$ & $\begin{array}{l}\text { porco } \\
\text { porco }\end{array}$ & VAL & $\mathrm{BN}$ & MAZ & VAT \\
\hline Vitela assada & Carnes Assadas & $\begin{array}{l}\text { assado } \\
\text { empada }\end{array}$ & $\begin{array}{l}\text { quadrúpede } \\
\text { quadrúpede }\end{array}$ & $\begin{array}{l}\text { vitela } \\
\text { vitela }\end{array}$ & & $\mathrm{BN}$ & MAZ & VAT \\
\hline Desfiado de bezerro & Carnes Assadas & frito & quadrúpede & bezerro & VAL & $\mathrm{BN}$ & MAZ & VAT \\
\hline Carneiro assado & Carnes Assadas & assado & quadrúpede & carneiro & VAL & $\mathrm{BN}$ & MAZ & VAT \\
\hline Cabras novas, cordeiros & Carnes Assadas & assado & $\begin{array}{l}\text { quadrúpede } \\
\text { quadrúpede }\end{array}$ & $\begin{array}{c}\text { cordeiro } \\
\text { cabra } \\
\end{array}$ & VAL & $\mathrm{BN}$ & MAZ & VAT \\
\hline Gansos & Carnes Assadas & assado & ave & ganso & VAL & $\mathrm{BN}$ & MAZ & VAT \\
\hline Galinhas assadas & Carnes Assadas & $\begin{array}{l}\text { assado } \\
\text { empada }\end{array}$ & $\begin{array}{l}\text { ave } \\
\text { ave }\end{array}$ & $\begin{array}{l}\text { galinha } \\
\text { galinha }\end{array}$ & VAL & $\mathrm{BN}$ & MAZ & VAT \\
\hline Capões, galinhas e galos & Carnes Assadas & assado & ave & $\begin{array}{c}\text { capão } \\
\text { galinha } \\
\text { galo } \\
\end{array}$ & VAL & $\mathrm{BN}$ & MAZ & VAT \\
\hline Coelhos assados & Carnes Assadas & $\begin{array}{l}\text { assado } \\
\text { empada } \\
\end{array}$ & $\begin{array}{l}\text { quadrúpede } \\
\text { quadrúpede }\end{array}$ & $\begin{array}{l}\text { coelho } \\
\text { coelho }\end{array}$ & VAL & $\mathrm{BN}$ & MAZ & VAT \\
\hline Capões gordurosos & Carnes Assadas & assado & ave & capão & & & & VAT \\
\hline Pombas assadas & Carnes Assadas & $\begin{array}{l}\text { assado } \\
\text { empada } \\
\end{array}$ & $\begin{array}{l}\text { ave } \\
\text { ave }\end{array}$ & $\begin{array}{l}\text { pomba } \\
\text { pomba }\end{array}$ & VAL & $\mathrm{BN}$ & & VAT \\
\hline Cisnes & Carnes Assadas & assado & ave & cisne & VAL & $\mathrm{BN}$ & MAZ & VAT \\
\hline Pavões & Carnes Assadas & assado & ave & pavão & VAL & $\mathrm{BN}$ & MAZ & VAT \\
\hline $\begin{array}{l}\text { Leitão recheado } \\
\text { Falso grenon }\end{array}$ & $\begin{array}{c}\text { Carnes Assadas } \\
\text { Entremezes }\end{array}$ & $\begin{array}{l}\text { assado } \\
\text { cozido } \\
\text { cozido } \\
\end{array}$ & $\begin{array}{l}\text { quadrúpede } \\
\text { ave } \\
\text { Quadrúpede }\end{array}$ & $\begin{array}{c}\text { leitão } \\
\text { ave doméstica } \\
\text { vitela }\end{array}$ & $\begin{array}{l}\text { VAL } \\
\text { VAL }\end{array}$ & $\begin{array}{l}\mathrm{BN} \\
\mathrm{BN}\end{array}$ & $\begin{array}{l}\text { MAZ } \\
\text { MAZ }\end{array}$ & $\begin{array}{l}\text { VAT } \\
\text { VAT }\end{array}$ \\
\hline Delicado & Entremezes & cozido & ave & & VAL & $\mathrm{BN}$ & & VAT \\
\hline Aves recheadas & Entremezes & assado & $\begin{array}{c}\text { ave } \\
\text { quadrúpede }\end{array}$ & $\begin{array}{c}\text { galinha } \\
\text { carneiro } \\
\text { vitela } \\
\end{array}$ & VAL & $\mathrm{BN}$ & MAZ & VAT \\
\hline Sem nome & Entremezes & cozido & ave & galinha & & $\mathrm{BN}$ & MAZ & \\
\hline Geléia de peixe ou carne & Entremezes & cozido & quadrúpede & & VAL & $\mathrm{BN}$ & MAZ & VAT \\
\hline Cisne revestido & Entremezes & assado & ave & cisne & VAL & $\mathrm{BN}$ & & VAT \\
\hline Sálvia fria & Entremezes & cozido & ave & & VAL & $\mathrm{BN}$ & MAZ & VAT \\
\hline Ensopado de leitão & Entremezes & cozido & quadrúpede & leitão & VAL & $\mathrm{BN}$ & MAZ & VAT \\
\hline Caldo de frango & Pratos $\mathrm{p} /$ doentes & cozido & ave & frango & VAL & $\mathrm{BN}$ & MAZ & VAT \\
\hline $\begin{array}{l}\text { Água rosada de capão } \\
\text { ou frango }\end{array}$ & Pratos $\mathrm{p} /$ doentes & cozido & ave & $\begin{array}{l}\text { capão } \\
\text { frango }\end{array}$ & VAL & $\mathrm{BN}$ & MAZ & VAT \\
\hline Manjar branco de capão & Pratos $\mathrm{p} /$ doentes & cozido & ave & capão & VAL & $\mathrm{BN}$ & MAZ & VAT \\
\hline Cuminade de peixe & Pratos $\mathrm{p} /$ doentes & cozido & ave & & & & & VAT \\
\hline Outras sopas menores & $\begin{array}{c}\text { Conhecimento } \\
\text { Geral } \\
\end{array}$ & $\begin{array}{l}\text { cozido } \\
\text { cozido }\end{array}$ & $\begin{array}{l}\text { quadrúpede } \\
\text { quadrúpede }\end{array}$ & $\begin{array}{l}\text { vitela } \\
\text { porco }\end{array}$ & & & & VAT \\
\hline Um poitevine & Molhos quentes & fervido & ave & & VAL & $\mathrm{BN}$ & MAZ & \\
\hline
\end{tabular}


Na Alta Idade Média, a profissão de açougueiro (entre outras, como estalajadeiro, mágico, alquimista, médico, cirurgião, soldado, prostituta etc.) havia sido desprezada e condenada, proibida aos clérigos e denunciada como propiciadora do pecado. O tabu do sangue, que atuava sobre açougueiros, médicos, cirurgiões e soldados, e o tabu da impureza e da sujeira, consistem em alguns dos motivos desses afastamentos. Mas também a associação desse trabalho com o pecado capital da gula. Mesmo assim, os açougueiros ainda conservavam o direito à sepultura cristã e o direito de dar esmola, negados aos usurários e às prostitutas. Le Goff observa a esquizofrenia social semelhante em que viviam açougueiros e usurários, poderosos e desprezados pelas cidades medievais. ${ }^{106}$.

Entre os séculos IV e XIII o contato com carne e sangue conferiu ao cozinheiro um caráter quase "impuro" e talvez por isso a literatura culinária não tenha se desenvolvido na Europa. Mas nos séculos XIV e XV, esse tipo de literatura tornou-se sucesso, principalmente se a obra contava com o prestígio do nome do cozinheiro de um grande príncipe ${ }^{107}$, como Taillevent ou Chiquart ${ }^{108}$, ou ainda do cozinheiro que trabalhasse para eclesiásticos, como Mestre Martino ${ }^{109}$ ou Jean de Bockenhim ${ }^{110}$.

A partir do século XII ocorreu uma reabilitação da ideia de trabalho, vista na Alta Idade Média como castigo e penitência. Tal conceito cedeu lugar à ideia de que o trabalho útil poderia conduzir à salvação e os laboratore, termo que nos séculos XII e XIII passou a designar também os trabalhadores urbanos, contribuíam para a sociedade e para o plano divino ${ }^{111}$.

Em 1386, a cozinha do rei da França dispunha de 73 pessoas em seu serviço, todos quase sempre homens. Tratava-se de trabalho árduo e os castigos corporais eram comuns, mas os mestres cozinheiros, topo da carreira, recebiam, além dos salários, rendas e benefícios de pessoas condenadas à morte. $\mathrm{O}$ mestre da guarnição e os escudeiros de cozinha ${ }^{112}$ eram encarregados do abastecimento. Os cozinheiros eram vistos como os verdadeiros profissionais: o primeiro cozinheiro era chamado mestre de cozinha, a quem competia a inspeção da carne, a separação dos bocados, a reserva dos

\footnotetext{
106 LE GOFF, Jacques. A bolsa e a vida. Tradução Rogerio Silveira Muoio. São Paulo: Editora Brasiliense, 2004, p. 47-50.

${ }^{107}$ LAURIOUX, Bruno. A Idade Média à mesa. Tradução Elsa Andringa. Sintra: Publicações EuropaAmérica, 1989, p. 78-79.

${ }^{108}$ Mestre cozinheiro de Amadeu VIII, primeiro duque de Sabóia (século XV).

${ }^{109}$ Mestre cozinheiro do patriarca de Aquileia (século XV).

${ }^{110}$ Mestre cozinheiro do papa Martinho V (século XV).

${ }^{111}$ Idem, 1992, p. 79-121

${ }^{112}$ Frequentemente nobres e homens de confiança do rei.
} 
melhores para o príncipe e a distribuição entre os cozinheiros de especialidades e do trivial. Cabia também ao mestre supervisionar e manter a ordem e a limpeza, provar pratos para verificar se estavam precisamente ao gosto e se não estavam envenenados, garantir as provisões de carvão e ovos, garantir que os ingredientes não se esgotassem, fornecer sempre refeições adequadas no caso do banquete se prolongar e servir a cada conviva porções compatíveis com sua categoria social. Os ajudantes auxiliavam no preparo das refeições. Havia ainda cozinheiros de assados e espetos, sopeiros e o cozinheiro encarregado dos molhos.

As funções que abarcavam o pessoal de condição inferior eram as de sopradores, que atiçavam o fogo dos caldeirões; lenhadores, que traziam a lenha e o carvão; porteiros e contínuos, que controlavam os carros de transporte de víveres e utensílios nas portas das cozinhas; guarda-comidas, responsáveis pela provisão de carnes cruas e salgadas; trabalhadores do almofariz, louceiros, que lavavam utensílios e buscavam água; e crianças ajudantes de cozinha, que limpavam carnes e peixes, ajudavam a virar espetos, levavam recados e executavam quaisquer serviços menores que lhes fossem solicitados $^{113}$.

A cozinha burguesa contava, na maioria dos casos, com apenas um cozinheiro, frequentemente uma mulher ${ }^{114}$, mas seu equipamento não costumava ser escasso ${ }^{115}$.

Era possível contratar um cozinheiro profissional ${ }^{116}$, junto ou não com um escudeiro de cozinha, em ocasiões festivas, quando não se podia contar permanentemente com tais profissionais em casa. Era conhecido como o cozinheiroestalajadeiro. Também para comer fora de casa contava-se com os estalajadeiros e taberneiros, que frequentemente ofereciam dormida, além de refeição. A presença frequente de prostitutas nesses estabelecimentos contribuía para a associação da carne com o prazer sexual no imaginário medieval ${ }^{117}$.

$\mathrm{Na}$ organização dos ofícios as corporações tinham um papel muito semelhante ao de cartel, limitando tanto as possibilidades de fraude como de expansão, e embora

\footnotetext{
${ }^{113}$ LAURIOUX, Bruno. A Idade Média à mesa. Tradução Elsa Andringa. Sintra: Publicações EuropaAmérica, 1989, p. 74-79.

${ }_{114}$ As mulheres não eram comumente empregadas nas cozinhas aristocráticas.

${ }^{115}$ LAURIOUX, op.cit., p. 79.

${ }^{116}$ Esse trabalho era similar ao do estalajadeiro.

${ }^{117}$ LARIOUX, p. 80-85.
} 
fossem essencialmente profissionais é complexo distinguir entre o caráter coorporativo e o político. Em Montpelier, os chefes de ofício estavam na base do sistema eleitoral ${ }^{118}$.

Os açougueiros de Paris receberam os privilégios em 1162 e os estatutos em 1182. Os de Pontoise foram regulamentados em 1162 e os de Toulouse, em $1184^{119}$.

Os açougueiros eram tratados com deferência, pois contribuíam para o bem geral da cidade (o mesmo com padeiros e peixeiros), fornecendo os víveres do dia-a-dia. Os estabelecimentos comerciais de gêneros alimentícios ficavam no andar térreo de imóveis ao longo de todas as ruas, ao lado de comerciantes de diversos tipos. Mas o açougue e a peixaria foram, desde longa data, separados e agrupados pelas autoridades. As sanções para a adulteração iam da destruição dos alimentos e multas a penas infamantes e proibição de exercer o ofício. As mulheres eram muito comuns no comércio de alimentos, mas não no caso particular dos açougues ${ }^{120}$.

Na primeira metade do século XIV surgiram novos ofícios, que não criaram, no entanto, novos produtos. Em algumas cidades importantes, os açougueiros muito cedo deixaram para tripeiros as vísceras, para que fossem vendidas em mercado próprio. A partir de meados do século XIII surgiram os profissionais chamados porcatores, salaterii, salaroli, lardaroli, que separavam e salgavam a carne e o toucinho, mas ao que parece não matavam os animais e nem podiam negociar diretamente com os criadores; eles compravam diretamente do açougueiro. Os charcuteiros apareceram nas cidades mediterrâneas no decorrer do século XIV, e, no início, não formavam uma comunidade distinta. Os charcuteiros-salsicheiros surgiram tardiamente na região setentrional $^{121}$.

Os chamados coquinarii, cozinheiros, no final da Idade Média, eram na verdade os salsicheiros-assadores, que desempenhavam papel importante na alimentação dos que tinham menos recursos. Possuíam por ofício jurado, regulamentado, o direito de cozinhar carnes e fabricar salsichas, bem como comercializá-las. Fabricavam também o chouriço, embora fosse proibido pela regulamentação ${ }^{122}$.

\footnotetext{
118 MONTANARI, Massimo. (Org.). História da alimentação. Tradução Luciano Vieira Machado; Guilherme J. F. Teixeira. São Paulo: Estação Liberdade, 1998, p. 77-79 et seq.

${ }^{119}$ Ibidem, p. 79 et seq.

${ }^{120}$ DESPORTES, Françoise. Os ofícios da alimentação. In: FLANDRIN, Jean Louis ; MONTANARI, Massimo. (Org.). História da Alimentação. Tradução Luciano Vieira Machado; Guilherme J. F. Teixeira. São Paulo: Estação Liberdade, 1998, p. 422-436.

${ }^{121}$ Ibidem, p. 422 et seq.

${ }^{122}$ LAURIOUX, Bruno. A Idade Média à mesa. Tradução Elsa Andringa. Sintra: Publicações EuropaAmérica, 1989, p. 81.
} 
Os pasteleiros eram ambulantes e se deslocavam nas cidades com carrinhos de mão, sobre os quais montavam pequenos fornos e comercializavam empadas recheadas de carne ou peixe, muitas vezes encomendadas pelas tabernas para serem oferecidas aos clientes, acompanhando o vinho. Os estudantes solteiros recorriam frequentemente aos pasteleiros, que praticavam baixos preços. Quase sempre esses profissionais utilizavam carnes pouco frescas, o que lhes permitia um preço final baixo. Era comum que os pasteleiros obtivessem com os mestres cozinheiros das casas principescas os restos e tripas que, muitas vezes, tinham o direito após a refeição de seus amos ${ }^{123}$. No entanto, um decreto inglês de 1379 proibia essa prática ${ }^{124}$.

Os talhantes comercializavam carneiros, ovelhas, cordeiros, vitelas, bezerros, bois e vacas. Caprinos, em menor quantidade. A carne de cavalo era proibida pela Igreja $^{125}$. Na Sicília, um encarregado do abate de animais recebia, em 1308, além do salário, três pães por dia e $2,4 \mathrm{~kg}$ de carne por semana ${ }^{126}$.

Os magarefes eram ricos artesãos urbanos, que negociavam carne, animais vivos e peixes $^{127}$.

\footnotetext{
${ }^{123}$ LAURIOUX, Bruno. A Idade Média à mesa. Tradução Elsa Andringa. Sintra: Publicações EuropaAmérica, 1989, p. 83.

${ }^{124}$ HENISCH, Bridget Ann. Fast and feast: food. In: Medieval society. University Park, 1976, p. 78.

${ }^{125}$ LAURIOUX, Bruno. A Idade Média à mesa. Tradução Elsa Andringa. Sintra: Publicações EuropaAmérica, 1989, p. 57.

${ }^{126}$ MONTANARI, Massimo. A fome e a abundância: história da alimentação na Europa. Tradução Andréa Doré. São Paulo: Edusc, 2003, p. 99.

${ }^{127}$ STOUFF, Louis. Ravitaillement et alimentation em Provence aux XIV e XVe siècles. Paris: Mouton, 1970, p. 158-165.
} 


\subsubsection{Economia}

Na Alta Idade Média, a conjugação da agricultura com a caça, pesca, coleta e criação de gado, e a relação favorável entre população e recursos, permitiu uma alimentação variada a todos os níveis sociais. As fontes de aprovisionamento eram acessíveis a todos e a carne não faltava. Ninguém era privado do uso dos espaços incultos e as leis germânicas entre os séculos VI e VIII preocupavam-se mais com os bosques do que com os limites agrários ${ }^{128}$.

George Duby se referiu à situação alimentar na Europa entre os séculos XI e XIII como um surto agrícola. A cultura de cereais se expandiu em detrimento dos pastos, charnecas, florestas, charcos, e até do mar, modificando tanto o equipamento técnico como as relações de mão-de-obra e métodos de trabalho. Os arroteamentos culminaram no século XII, impulsionados por uma dupla iniciativa de camponeses e senhores, e refletiram a mudança de atitude da aristocracia. Com a explosão demográfica, os camponeses famintos forneceram a mão-de-obra, mas foi preciso também que os donos dos terrenos consentissem que estes fossem transformados em terras de lavoura. Num primeiro momento, os senhores apenas toleraram, mas em seguida passaram a incentivar esse movimento. Em 1241, em Origgio, 45\% das terras eram deixadas sem cultivo. Em 1320, essa percentagem caiu para $16 \%{ }^{129}$.

O desejo de preservar áreas incultas, que favoreciam o consumo de carne, chocava-se com a necessidade de aumentar os campos cultivados para responder à demanda por alimento gerada pela pressão demográfica. Um hectare de bosque podia alimentar dois porcos. Um hectare de pasto, algumas ovelhas. Um hectare de terra arável rendia mais e os cereais conservavam-se por mais tempo que a carne.

A derrubada das florestas para criação de novas áreas de cultivo foi uma iniciativa dos mosteiros, vista com maus olhos pelos nobres senhores de terra. A rainha Brunichilde enfureceu-se com o beato Meneleo, que insistia na derrubada das florestas onde a soberana "ia à caça"130. Mas mais do que tudo, prejudicava os camponeses, que dependiam do uso coletivo dos bosques tanto para economia quanto para solidariedade

\footnotetext{
${ }^{128}$ STOUFF, Louis. Ravitaillement et alimentation em Provence aux XIV e XVe siècles. Paris: Mouton, 1970 , p. $42-44$.

${ }^{129}$ DUBY, George. Economia rural e vida no campo no Ocidente medieval. Tradução Lisboa, 1987, p. 91-118.

${ }^{130}$ MONTANARI, Massimo. A fome e a abundância: história da alimentação na Europa. Tradução Andréa Doré. São Paulo: Edusc, 2003, p. 52-60.
} 
social. Mas o desmatamento ainda era a resposta mais rápida para a demanda alimentar, além de uma nova demanda por "civilização". Iniciado no século IX por iniciativa da igreja, prossegue posteriormente com o apoio de senhores, cidades e da própria comunidade camponesa. De certa forma, trata-se de uma escolha forçada.

No início, a expansão se deu por alargamento das antigas explorações, por iniciativas individuais de arroteamento, fazendo proliferar a pequena propriedade camponesa (XI e XII). Em seguida, passou-se a um movimento de fundação de novas aldeias, em espaços pertencentes à aristocracia, que investiu diretamente no mercado de cereais e foi beneficiada financeiramente. E uma terceira forma de expansão diz respeito ao povoamento intercalar de colonos que se instalavam em lugares ermos, a certa distância uns dos outros. Parece que esse último caso correspondia a organismos de produção em que a criação de gado na pradaria natural era o principal recurso e a cultura de cereais era complementar, o que poderia representar um refluxo do surto agrícola $^{131}$.

No século VIII já aparecem registros de monastérios que subtraem espaços incultos às comunidades rurais. Nos séculos X e XI é a vez da nobreza laica, que exige cada vez mais dos camponeses, numa necessidade de afirmação de poder gerada em grande parte pela pressão do aumento demográfico. No século IX os contratos agrários determinaram a derrubada da floresta improdutiva, que não produzia carvalhos ou outro alimento para animais. Na segunda metade do século XI o ritmo já era bem mais intenso. As reservas multiplicaram-se e a caça clandestina passou a ser combatida com rigor.

As destruições das florestas entre os séculos XI e XIII levaram à diminuição considerável de cervos e javalis. O pastoreio passou a ser regulamentado e o direito erbático e ghiandático (uso de gramíneas e frutos do carvalho) limitado. Também foi limitado o direito de respiga ${ }^{132}$. Até o século XIV, tais direitos haviam praticamente desaparecido de áreas centrais, permanecendo apenas em faixas marginais. As cidades também participaram do processo de apropriação de zonas incultas, e os bosques comuns passaram a ser os bosques da comuna ${ }^{133}$.

As gorduras animais tornaram-se mais raras na dieta camponesa $\mathrm{e}$ frequentemente o cozimento passou a ser feito exclusivamente em água. Os camponeses

${ }^{131}$ DUBY, George. Economia rural e vida no campo no Ocidente medieval. Lisboa, 1987, p. 91-118.

${ }^{132}$ Direito de apanhar as espigas que os ceifadores tenham deixado no campo, após a colheita.

133 MONTANARI, Massimo. A fome e a abundância: história da alimentação na Europa. Tradução Andréa Doré. São Paulo: Edusc, 2003, p. 56-116. 
tentaram opor-se através de denúncias e litígios, mas quase sempre foram brutalmente expropriados. Um cronista do século XI relata uma revolta camponesa ocorrida no século X, no ducado da Normandia, por essa razão. Foi violentamente reprimida por Raul, conde de Evreux. Também será essa a reivindicação camponesa na revolta de 1382, na Inglaterra, e de 1525 , na Alemanha ${ }^{134}$.

A expansão diminuiu progressivamente ao longo do século XII, algumas vezes diminuiu de forma brusca, e teve termo no XIII. Nesse momento os bosques e os pastos já haviam se tornado preciosos e defendidos duramente pelos que detinham seu usufruto $^{135}$.

Mesmo assim, a expansão agrária não conseguiu dar conta do sustento da população crescente.

As adversidades climáticas se fazem sentir de forma mais violenta em economias estritamente agrícolas. O século IX e, ainda mais, o século XI, foram marcados por sérias crises alimentares. Durante a fome do século XI, há relatos de consumo de carne de animais mortos e mesmo de carne humana, de ataques a crianças e viajantes, de cadáveres desenterrados e consumidos.

Mesmo com os períodos de fome, entre os anos1200 e 1250, a expansão das culturas ainda proporcionou uma situação de relativo bem estar alimentar à população, mas a partir daí não conseguiu mais compensar o aumento demográfico. Em 1270, o crescimento agrícola começou a estagnar após a exploração do solo ter atingido o limite máximo $^{136}$.

O crescimento econômico foi interrompido e a expansão agrária voltou a diminuir. O equilíbrio entre o aumento da população e o aumento da produção rompeuse e a fome tornou-se protagonista absoluta. Já a partir do século XIV sucederam-se ciclos de duríssimas carestias. As colheitas ruins se sucederam de maneira nunca antes vista. As fomes mais terríveis foram as de 1315-1317 (costas atlânticas) e 1346-1347 (todo o continente). Em 1348 a peste negra dizimou uma população já em profunda

\footnotetext{
${ }^{134}$ MONTANARI, Massimo. A fome e a abundância: história da alimentação na Europa. Tradução Andréa Doré. São Paulo: Edusc, 2003, p. 63-207.

${ }_{135}$ DUBY, George. Economia rural e vida no campo no Ocidente medieval. Lisboa: 1987, p. 91-118.

${ }^{136}$ Idem, 2006, p. 35-45.
} 
penúria $^{137}$ (vale observar que nas regiões de criação e de pesca a epidemia encontrou maior resistência) $)^{138}$.

Depois da peste negra (1348-1350), uma crise demográfica atingiu a Europa e a economia retomou momentaneamente as características silvo-pastoris, próprias do início da Idade Média ${ }^{139}$. A situação melhorou com a diminuição da população. João de Mussis registrou os banquetes de casamento em Piacenza, em 1388, como uma verdadeira Cocanha (Begondi). Capão, carne assada, flambados, açúcar, especiarias, frangos, galinhas, perdizes, lebres, javalis, veados, gelatinas de carne, vitelos, marrecos e patos foram servidos durante dois dias. Tratou-se de uma redescoberta da vontade de viver e festejar que teve na carne seu protagonista absoluto nos cardápios. Era a carne o símbolo de status, distintivo do regime alimentar. Mas o consumo cresceu também entre as camadas populares na segunda metade do XIV. Os preços baixaram e os salários subiram, graças à crise demográfica. Pastos e prados retomaram muitas zonas e aumentaram as propriedades especializadas em criação. $\mathrm{O}$ comércio de carne (tanto de curto como de longo alcance) tomou impulso. Regiões do Leste (Polônia, Hungria, Balcãs) passaram a enviar gado para o Ocidente ${ }^{140}$.

W. Abel estimou para o século XV um consumo de $100 \mathrm{~kg}$ de carne por pessoa (ano), na Alemanha. O que, considerando a abstinência imposta pela igreja, resulta em até $500 \mathrm{~g}$ de carne por dia. No século XVIII não chegou a $14 \mathrm{~kg}$. É provável que os países do norte tenham apresentado um consumo maior. No Mediterrâneo deve ter variado entre 20 e $70 \mathrm{~kg}$ anuais em média. Em Paris, no XVI, um observador registrou que artesãos e comerciantes comiam veado e perdiz nos dias gordos como os ricos ${ }^{141}$.

\footnotetext{
${ }^{137}$ RIERA-MELIS, Antoni. Sociedade feudal e alimentação (séculos XII e XIII). In: FLANDRIN, Jean Louis; MONTANARI, Massimo. (Org.). História da alimentação. Tradução Luciano Vieira Machado; Guilherme J. F. Teixeira. São Paulo: Estação Liberdade, 1998, p. 408.

${ }^{138}$ MONTANARI, Massimo. A fome e a abundância: história da alimentação na Europa. Tradução Andréa Doré. São Paulo: Edusc, 2003, p. 84-94.

${ }^{139}$ Idem, 1998, p. 382-386.

${ }^{140}$ Idem, 2003, p. 94-97.

${ }^{141}$ Ibidem, p. 97-135.
} 


\section{CAPÍTULO II}

\section{TENSÕES E REPRESENTAÇÕES}

\subsection{As controvérsias sociais dos valores cristãos}

A afirmação como religião oficial do império incluiu o cristianismo no sistema de valores do mundo romano, no século IV. E a nova fé promoveu o prestígio do pão, do vinho e do óleo por toda a Europa. As igrejas e monastérios alargaram progressivamente o cultivo de vinho e cereais até latitudes antes impensáveis ${ }^{142}$.

O cristianismo levou ao auge a ideia romana de virtus. Para tanto, apoiou-se na ética das camadas médias e pobres da sociedade romana ${ }^{143}$. Peter Brown observou que foram os despossuídos romanos que legaram aos cristãos a crítica ao uso supérfluo de alimentos. A condenação do luxo dos antigos romanos serviu de base à atitude cristã para com o consumo incontrolado das pessoas da Idade Média e Moderna ${ }^{144}$.

Para o pensamento paulino, o corpo é diametralmente oposto à alma e entre eles estabelece-se o permanente combate entre fraqueza-morte-vício e força-vida-virtude. A comida tem participação evidente na tensão do embate entre corpo e alma. Peter Brown observou que, nas cartas de Paulo, "o corpo humano nos é apresentado como uma fotografia batida contra o sol: trata-se de uma silhueta negra cujas bordas estão inundadas de luz"145. A tendência é colocar nombito negativo o espaço da materialidade. A associação direta entre o pecado carnal e a Queda esteve fortemente

\footnotetext{
142 MONTANARI, Massimo. A fome e a abundância: história da alimentação na Europa. Tradução Andréa Doré. Edusc: São Paulo, 2003, p. 30-31.

${ }^{143}$ FERNANDES, João Azevedo. Selvagens bebedeiras: álcool, embriaguez e contatos culturais no Brasil colonial. 2004. 392 f. Tese (Doutorado em História) - Departamento de História, Universidade Federal Fluminense, Rio de Janeiro, 2004, p. 207-211.

${ }^{144}$ BROWN, Peter. Corpo e sociedade: o homem, a mulher e a renúncia sexual no início do cristianismo. Tradução V. Ribeiro. Rio de Janeiro: Zahar, 1990, passim.

${ }^{145}$ Ibidem, p.49.
} 
presente no imaginário medieval ${ }^{146}$. O personagem bíblico Esaú vendeu sua primogenitura por um prato de lentilhas (Gênesis 25, 29-34); Noé embriagou-se de vinho e ficou nu, expondo as vergonhas (Gênesis 9, 20-27).

No Tractus de octo spiritibus malitiae, atribuído ao abade Nilo de Ancira, é afirmado que a comida e o prazer (paladar) afastaram a humanidade do Paraíso. ${ }^{147}$. É comum a menção ao desejo da carne, ainda mais que ao desejo do ventre, especificamente. Uma ambivalência lexical, já que carne (caro) não é necessariamente intercambiável com corpo (corpus), dá margem a divergências na interpretação do pecado carnal: gula ou luxúria, sexual ou do ventre ${ }^{148}$. No entanto, Deus glorificou o corpo ao se fazer homem e, pela eucaristia, perpetuou essa aliança entre o criador e a criatura, o que abre espaço para a discussão teológica, paralela à percepção negativa do corpo, de que deve existir também a percepção positiva do corpo sagrado ${ }^{149}$. Em De trinitate, Hilário de Poitiers (300-368 d.C) afirmou que a humanidade de Cristo fez a carne eterna e humana, e essa comunhão se perpetuará pela eucaristia, o que impossibilita a rejeição do corpo ${ }^{150}$.

As normas eclesiásticas proibiam o consumo de carne, ou até mesmo de todos os produtos de origem animal, em quase metade do ano. A Europa católica praticava 166 dias de jejum religioso, de abstenção de carne e ovos, por ano, sendo 40 deles extremamente rigorosos ${ }^{151}$, a Quaresma, do latim quadragésima, os quarenta dias que antecedem a Páscoa. O Carnaval servia de pretexto à inversão dos valores e à subversão da ordem social. Liberava-se a tensão gerada pela expectativa da Quaresma, tornando-se uma espécie de orgia alimentar, sobretudo na terça-feira-gorda, que antecedia a quartafeira de Cinzas. E nos meses que se seguiam à difícil abstinência da Quaresma, o jejum era bem menos respeitado nos dias magros ${ }^{152}$.

\footnotetext{
${ }^{146}$ ASFORA, Wanessa. Apício: história da incorporação de um livro de cozinha na Alta Idade Média (séculos VIII e IX). 2009. 272 f. Dissertação (Mestrado em História Social) - Faculdade de Filosofia, Letras e Ciências Humanas, Universidade de São Paulo, São Paulo, 2009, p. 49.

${ }^{147}$ NILO. Tractus de octo spiritibus malitiae. PG, v.79, col. 1145B1146B.

${ }^{148}$ SCHMITT, Jean-Claude. Corpo e alma. Tradução Eliana Magnani In: LE GOFF, Jacques; SCHMITT, Jean-Claude. (Org.). Dicionário temático do Ocidente Medieval. São Paulo: Edusc, v. 2, 2006, p. 255256.

${ }^{149}$ Ibidem, p. 257.

${ }^{150}$ HILÁRIO DE POITIERS. La Trinité. Edição e tradução de G. M. Durand; Ch. Morel; G. Pelland. SC, 1999 , v. 443.

${ }^{151}$ CARNEIRO, Henrique. Comida e sociedade, uma história da alimentação. Editora Campus, 2003, p. 67-68

${ }^{152}$ LAURIOUX, Bruno. A Idade Média à mesa. Tradução Elsa Andringa. Sintra: Publicações EuropaAmérica, 1989, p. 14-15.
} 
A renúncia, praticada inicialmente por eremitas e monges, estendeu-se para toda a sociedade, nas quartas e sextas-feiras, vigílias e festividades, pequenas e grandes Quaresmas. Persistia no ponto de vista cristão uma conotação pagã a respeito do consumo de carne, que favoreceria o excesso de sensualidade e contrariava um pacifismo herdado da filosofia helenística. A proibição do uso da gordura animal, em um a cada três dias, difundiu o consumo de óleo vegetal no Norte da Europa ${ }^{153}$. O peixe só foi admitido nos jejuns a partir do século IX, excluindo-se, ainda, os chamados peixes gordos, como baleias (embora a gordura salgada da baleia fosse considerada "toucinho de pobre" na época do jejum) e golfinhos, por sua carne ser muito semelhante à de animais terrestres ${ }^{154}$. Era tolerado o consumo de crustáceos, caracóis e animais como castor, lontra, cisne e garça. Os ovos eram vetados durante a Quaresma, mas não nos demais dias de alimentação restrita ${ }^{155}$. A necessidade de peixe seco, defumado ou salgado deu origem a uma "indústria" voltada para esse abastecimento, principalmente de arenque, peixe que simbolizava a Quaresma pelo seu consumo mais vulgarizado ${ }^{156}$.

Além das receitas constantes nas seções de peixes, o Viandier apresenta duas receitas anteriores ao século XV específicas de "viandas para quaresma", conforme ilustrado pela tabela abaixo ${ }^{157}$. Além de 15 receitas de ensopados (sopas espessas) sem carne.

Tabela 6 - Receitas específicas de viandas para Quaresma no Viandier

\begin{tabular}{|l|c|c|c|c|c|c|}
\hline \multicolumn{1}{|c|}{ RECEITA } & $\begin{array}{c}\text { MODO DE } \\
\text { PREPARO }\end{array}$ & \multicolumn{2}{|c|}{ ESPÉCIE } & \multicolumn{3}{|c|}{$\begin{array}{c}\text { CONSTANTE NOS } \\
\text { MANUSCRITOS }\end{array}$} \\
\hline Pudins e tortas na Quaresma & Cozido & lúcio & VAL & BN & MAZ & VAT \\
& Cozido & carpa & & & & \\
& Cozido & enguia & & & & \\
\hline Purê de agrião & Cozido & & VAL & BN & MAZ & VAT \\
& & & & & & \\
\hline
\end{tabular}

\footnotetext{
${ }^{153}$ No século XIV, o concílio de Angers admitiu a manteiga como alimento magro, oposto ao toucinho, considerado uma espécie de gordura gorda. Embora ainda fosse interditada durante a quaresma, a não ser em caso de dispensa. Com relação à dispensa papal, destaque-se que era algo frequente, devido às diversidades regionais. Carlos Magno mesmo, devido à falta de olivas, manifestou interesse pela obtenção de permissão do uso de "oleum lardinum" nos monastérios do norte.

154 MONTANARI, Massimo. A fome e a abundância: história da alimentação na Europa. Tradução Andréa Doré. São Paulo: EDUSC, 2003, p. 102-105.

155 TREFZER, Rudolf. Clássicos da literatura culinária: os mais importantes livros da história da gastronomia. trad. Marcelo Rondinelli. São Paulo: Senac, 2009, p. 29- 139.

${ }^{156}$ LAURIOUX, Bruno. A Idade Média à mesa. Tradução Elsa Andringa. Sintra: Publicações EuropaAmérica, 1989, p. 62.

${ }^{157}$ É interessante observar que a receita de Pudins e Tortas para a Quaresma é uma das poucas receitas constantes no Viandier, anteriores ao século XV, que utilizam açúcar no preparo.
} 
Tabela 7 - Receitas específicas de peixe para Quaresma no Viandier

\begin{tabular}{|l|c|c|c|c|}
\hline \multicolumn{1}{|c|}{ RECEITA } & \multicolumn{4}{|c|}{ CONSTANTE NOS MANUSCRITOS } \\
\hline Cuminade de peixe & VAL & BN & MAZ & VAT \\
\hline Caldo amarelo-verde de enguias & VAL & BN & & VAT \\
\hline Molho de cadoz & VAL & BN & MAZ & VAT \\
\hline Chaudumet de lúcio & VAL & BN & MAZ & VAT \\
\hline Um escaldado de enguia & VAL & BN & & VAT \\
\hline Caldo sarraceno & VAL & & MAZ & VAT \\
\hline Filhote de lampreia & & & MAZ & \\
\hline Ensopado de ostras & VAL & BN & MAZ & VAT \\
\hline Sopa de mostarda & & BN & MAZ & VAT \\
\hline Ensopado de ovos & & BN & MAZ & VAT \\
\hline Caldo de ovos da Alemanha & & BN & MAZ & VAT \\
\hline Leite provençal/Leite ligado & VAL & BN & MAZ & VAT \\
\hline Caldo verde de ovos e de queijo & VAL & BN & MAZ & VAT \\
\hline Um molho amarelado de peixe & VAL & BN & MAZ & VAT \\
\hline Molho de perca & VAL & BN & MAZ & VAT \\
\hline
\end{tabular}

O Ménagier apresenta seis sugestões para cardápio de jantares em dias em que não se devia comer carne. Abaixo seguem esses cardápios:

\section{XIX - Um jantar de peixe para a Quaresma}

Primeiro serviço: Maçãs cozidas, grandes figos provençais assados com louro sobre eles, agrião e azedinha com vinagre, sopa de ervilhas, enguias salgadas, arenque branco, molho de carne sobre peixe frio de água salgada ou doce.

Segundo serviço: Carpa, cadoz, solha, leuciscos, salmão, enguias.

\section{$X X$ - Outro jantar de peixe para a Quaresma}

Primeiro serviço: Maçãs cozidas, grandes figos provençais assados com louro sobre eles, agrião e azedinha com vinagre, sopa de ervilhas, enguias salgadas, arenque branco, molho de carne sobre peixe frio de água salgada ou doce.

Segundo serviço: Carpa, lúcio, solha, leuciscos, salmão, enguias do avesso com molho espesso e um guisado de cebola e erva ${ }^{158}$.

Terceiro serviço: Enguias pequenas, badejo frito, golfinho moído com frumento, crepes e tortas norueguesas.

Alternativa: Figos e uvas, hipocraz e coscorões.

\section{$X X I$ - Outro jantar de peixe}

Primeiro serviço: Sopa de ervilhas, patê, ensopado de ostras, ensopado branco de peixe-agulha e perca, um pudim de agrião, arenques, baleia salgada, enguias salgadas, cadoz ensopado.

Segundo serviço: Peixe fresco de água salgada ou doce, rodovalho, fatias $^{159}$, biscoito amanteigado, galantina de enguias. 
Terceiro serviço: $O$ melhor e mais saboroso assado que puder ser feito, tortas brancas, cadoz ou bacalhau, lagostim, percas com salsa e vinagre, tenca com sopas ${ }^{160}$, geleia.

\section{XXII - Outro jantar de peixe}

Primeiro serviço: Sopa de ervilhas, arenques, purê, enguias salgadas, ostras, um ragu de peixe-agulha e carpa.

Segundo serviço: Peixe de água doce, um soringue ${ }^{161}$ de enguias, tortas norueguesas e chouriço de festa, guisado de cebolas e ervas, empadas, bolinhos fritos.

Terceiro serviço: O melhor e mais saboroso assado que puder ser feito, arroz fantasia $^{162}$, tortas, leite frito ${ }^{163}$, e pequenos pastéis, salmão e tortas de sargo, um chawdon ${ }^{164}$.

Quarto serviço: Fatias, biscoitos fritos, canudos recheados, raízes de skirrit $^{165}$, lúcio frito, pratos glaceados, congros com nabo, tortas lombardas, enguias do avesso.

\section{XXIII - Outro jantar de peixe}

Primeiro serviço: Maçãs cozidas, figos maduros, vinho de Grenache, agrião e esporângios, sopa de ervilhas, sável, enguias salgadas, arenques e baleia salgada, percas e lulas num molho branco sobre bolinhos fritos.

Segundo serviço: O melhor peixe de água doce que puder ser encontrado e peixe de água salgada, enguias sem pele, recheio com molho quente, tencas com sopas, lagostim, tortas de brema e patrúcias cozidas na água.

Terceiro serviço: Frumento com golfinho, tortas norueguesas e cavala assada, enguias pequenas, ostras, lula frita, um crepe de lúcio.

\section{XXIV-Outro jantar de peixe}

Primeiro serviço: Sopa de ervilhas, arenque, enguias salgadas, ensopado negro de ostras, caldo de amêndoas, um ladrilhado ${ }^{166}$, um

\footnotetext{
${ }^{159}$ Viandier: Taillis. Fatias: Pegar figos, uvas, leite de amêndoas fervido, biscoitos, bolos e cascas de pão branco cortadas em pequenos cubos e ferver estes últimos itens no leite, com açafrão, para dar cor, e açúcar, e colocar tudo isto para ferver até ficar espesso o suficiente para fatiar. Servir em tigelas. (O termo taillis, usado em BN, VAT e também no Ménagier, deriva de taillier (cortar), e refere-se a etapa final da receita. $V A L$ utiliza o termo garlins, de origem desconhecida).

${ }^{160}$ Fatias de pão ensopadas.

${ }^{161}$ Um soringue é um caldo espesso. O nome é inspirado da forma de cocção da carne, sossenguar (em catalão ou provençal). A carne previamente assada ou parboilizada é frita (sempre com cebolas) e, posteriormente, sempre fervida num caldo de especiarias.

${ }^{162}$ Viandier: Ris engoulé. Arroz fantasia: Selecionar o arroz, lavar totalmente em água quente e deixar secar no fogo. Cozinhar fervendo em leite de vaca. Adicionar açafrão em pó no leite, para dar-lhe uma cor castanho-avermelhada, e gordura do caldo de carne da panela (O termo engoullé é derivado de goules, vermelho, produzindo a ideia de decoração, fantasia).

${ }^{163}$ Receita constante no Viandier denominada Layt lardé.

${ }^{164}$ Ensopado de miúdos.

${ }^{165}$ Sium sisarum (Skirret, Crummock) é uma planta apiacea que possui raízes brancas e doces (de 15 a 20 $\mathrm{cm}$ ) semelhantes à batata doce. Pode ser cozida, ensopada ou assada.

${ }^{166}$ Receita no Viandier denominada "tuille".
} 
caldo de peixe agulha e enguias, uma cretonada ${ }^{167}$, um caldo verde de enguias, tortas prateadas.

Segundo serviço: Peixe de água salgada ou doce, tortas de sargo e salmão, enguias do avesso, um guisado de cebolas e ervas, tenca com um caldo gorduroso, um manjar negro, crepes, losangos ${ }^{168}$, orillettes ${ }^{169}$, e tortas norueguesas, lúcio recheado e salmão.

Terceiro serviço: Frumento com golfinho, pommeaulx ${ }^{170}$ glaceadas, profiteroles e chastlets $^{171}$ espanhóis, peixe assado, geleia, lampreia, congros e rodovalhos com molho verde, sargo com agraço, leite frito, torta doce de creme e entremezes. Então, sobremesa.

Durante o jejum, teoricamente, só se fazia uma refeição ao dia ${ }^{172}$, embora fossem permitidas pequenas merendas e ingestão de vinho. No entanto, não eram incomuns as dispensas concedidas a doentes, grávidas, amas-de-leite, pobres, muito jovens e muito idosos ${ }^{173}$.

O Inferno era frequentemente representado por operações de cozinha, como no poema Pesadelo do Inferno, de Raoul de Houdenc (ca. 1165-ca 1230 d.C.), cuja obra apresenta a gula renascida na condenação dos demônios. Campeões vencidos são servidos em vinho de alhos, prostitutas ao molho verde, sacerdotisas com cebolas e freiras negras com torresmo, usuários com toucinho, assassinos dissolvidos em alho, sodomitas no espeto.

A postura que buscava a sobriedade, até mesmo a abstinência, teve boas possibilidades de se enraizar em regiões mais tradicionais da cultura romana, como a Itália, a Provença ou a Península Ibérica. Mas chocou-se frontalmente com os hábitos germânicos. A esfera alimentar e etílica foi vital na luta cristã pela conversão. Michel Rouche observou que a participação em banquetes unia a comunidade, colocando-a em comunicação com os deuses e que compartilhar refeições com alguém tornava a pessoa intocável. O banquete era regeneração e fonte da vida ${ }^{174}$.

\footnotetext{
${ }^{167}$ O cretonnee (termo derivado de cremare - cremar) indica uma longa fritura de ervilhas ou favas, sempre necessária no preparo desse prato.

${ }^{168}$ Massa cortada na forma de diamante.

${ }^{169}$ Massa frita, fina e açucarada.

${ }^{170}$ Fruta de formato similar à maçã.

${ }^{171}$ Castelos de massa recheada.

172 O Ménagier apresenta 6 sugestões de cardápio para jantar em dia de jejum de carne, mas nenhuma sugestão de cardápio de ceia para tais dias.

${ }^{173}$ CONTAMINE, Philippe. La vie quotidienne pendantla guerre de Cent Ans. Paris: Hachette, 1976, p. 228.

${ }^{174}$ ROUCHE, Michel. Le repas de fête à l'epoque carolingienne: essai sur quelques types derations alimentaires. In: Denis Menjot. (Org.). Manger et Boire au Moyen Age.Acte du Colloque de Nice, 1982, Publicacion de la Faculté des Lettres et Sciences Humaines de Nice, n. 27, $1^{\text {a }}$ série, Les Belles Lettres, 1984, p. 265-295.
} 
Nesse ponto os valores sociais chocam-se com os da ética religiosa. Essa tensão aparece de forma exemplar na biografia de Carlos Magno (742-814.), rei dos francos e imperador romano. Eginhardo (ca. 770-814 d.C.), escritor carolíngio, o descreve inicialmente como moderado no comportamento alimentar. Depois esclarece que era moderado no beber, mas no comer não conseguia, e os jejuns lhe faziam mal. Relata que suas refeições consistiam de apenas quatro pratos, mas não inclui na conta os assados oferecidos no espeto ao imperador pelos caçadores, e preferidos por ele a qualquer outro alimento. A descrição é de moderação cristã romana, mas as imagens, não. Carlos Magno sofreu de gota na velhice e desobedecia aos médicos que lhe pediam para não comer assados. Nem em trocá-los por cozidos o rei consentia. ${ }^{175}$.

No século XIII, o De Contemptu Mundi, do papa Inocêncio III (1198-1216 d.C. $)^{176}$, ataca a gula e a paixão por guloseimas ${ }^{177}$.

A Igreja medieval tentou combater a glorificação e o incentivo do consumo excessivo, mas só obteve resultados modestos. Os germânicos preservaram de sua origem indo-europeia a visão da embriaguez e do consumo de carne como ato de virilidade e coragem. Gregório de Tours (539-594 d.C.), na Historia Francorum, relatou como os francos bebiam e se empanturravam até caírem por todos os cantos da casa ${ }^{178}$.

Se o principal valor mundano era a voracidade alimentar, o principal valor espiritual era a recusa ao alimento. E nesse ponto a cultura cristã também não foi moderada, incentivando práticas rígidas de ascetismo, privação e renúncia ${ }^{179}$.

A primeira regra dietética da vida monástica é a renúncia à carne. E convém lembrar que dos extratos mais altos da sociedade provinha a maior parte dos monges ${ }^{180}$. Mas a verdade é que, fora do tempo do jejum, os monges comiam muito. Rouche calculou que as rações diárias dos monastérios mais ricos não tinham menos de cinco mil calorias ${ }^{181}$.

\footnotetext{
${ }^{175}$ MONTANARI, Massimo. A fome e a abundância: história da alimentação na Europa. Tradução Andréa Doré. São Paulo: EDUSC, 2003, p. 40-41.

${ }^{176}$ A datação refere-se ao pontificado.

${ }^{177}$ INNOCENT. De contemptu mundi, sive de miseria humanae. Charleston: Bibliolife, 2009.

${ }_{178}^{17}$ TOURS, Gregory of. A history of the Franks. Chicago: Acheron Press, 2012.

${ }^{179}$ Thietmar de Merseburg testemunha no século XI que os príncipes poloneses costumavam arrancar os dentes de quem transgredia as normas eclesiásticas relativas à abstinência de carne. E no capitular de partibus Saxoniae, Carlos Magno previa pena de morte para tal delito.

${ }^{180} \mathrm{O}$ monge inglês Alcuíno, no século VIII, visitou a Frísia a pedido de Carlos Magno e registrou que o bispo Alberico, por quem foi recebido, era "homem poderoso em vacas".

${ }^{181}$ ROUCHE, Michel. Le repas de fête à l'epoque carolingienne: essai sur quelques types derations alimentaires. In: Denis Menjot. (Org.). Manger et Boire au Moyen Age. Acte du Colloque de Nice, 1982, Publicacion de la Faculté des Lettres et Sciences Humaines de Nice, n. 27, $1^{\text {a }}$ série, Les Belles Lettres, 1984, p.265-295.
} 
A regra de São Bento só permitia carne aos doentes, mas a regra monástica tornou-se, ao longo da Idade Média, muito menos rigorosa e a dieta beneditina, variada e abundante. Além disso, festividades religiosas aconteciam 79 dias por ano, datas em que a ração era ainda maior ${ }^{182}$.

A carne já não era mais interdita aos monges no século XIII. Antes consumida apenas por doentes, após um certo tempo foi instituído um local próprio para seu consumo nos mosteiros, denominado domus carnium, que se tornou tão frequentado a ponto de ser necessária a organização de turnos. Foi preciso impor normas que determinavam a obrigação de jejum aos monges nos mesmos dias que os laicos a observavam $^{183}$.

Mas a falta de moderação e temperança no exagero quanto à norma ascética também provocou críticas no interior da própria Igreja. O consumo excessivo de peixes constituía um luxo em grande parte do Ocidente cristão. No século XII, Pedro Abelardo (1079-1142 d.C.) advertia as monjas do Paracleto sobre o risco da abstinência da carne converter-se em pecado da gula, pois a carne era comum e abundante, e o peixe era uma guloseima muito mais dispendiosa. No século XIII, a mensagem da primeira Batalha entre Carnaval e Quaresma é semelhante: a abstinência atinge os humildes ${ }^{184}$, para quem ainda é mais fácil obter carne do que peixe ${ }^{185}$.

No século XVI, a Reforma Protestante rejeitou a normativa dietética da Igreja Romana. Lutero (1483-1546 d.C.), baseado em textos evangélicos e paulinos, negou a legitimidade das disposições eclesiásticas, limitando apenas à Quaresma a guerra contra a carne.

Massimo Montanari levanta a possibilidade de que a noção de culpa e pecado continue pesando sobre a de prazer ainda hoje, arrastando a carga da tradição religiosa medieval. A moda das dietas esconderia, assim, valores penitenciais e de autopunição, derivados do excesso alimentar da sociedade atual. ${ }^{186}$.

\footnotetext{
${ }^{182}$ ROUCHE, Michel. Le repas de fête à l'epoque carolingienne: essai sur quelques types derations alimentaires. In: Denis Menjot. (Org.). Manger et Boire au Moyen Age. Acte du Colloque de Nice, 1982, Publicacion de la Faculté des Lettres et Sciences Humaines de Nice, n. 27, $1^{\mathrm{a}}$ série, Les Belles Lettres, 1984, p. 265-295.

${ }^{183}$ LAURIOUX, Bruno. A Idade Média à mesa. Tradução Elsa Andringa. Sintra: Publicações EuropaAmérica, 1989, p. 27.

${ }^{184}$ Durante o verão era muito difícil obter peixe e as localidades muito afastadas do mar sequer eram abastecidas de pescado.

${ }^{185}$ MONTANARI, Massimo. A fome e a abundância: história da alimentação na Europa. Tradução Andréa Doré. Edusc: São Paulo, 2003, p. 65.

${ }^{186}$ Ibidem, p. 212.
} 
A tabela abaixo apresenta as receitas constantes no Viandier e não constantes nas seções de Viandas para Quaresma ou Sopas sem carne, anteriores ao século XV, que não apresentam carne em seu preparo ${ }^{187}$ :

Tabela 8 - Receitas que não apresentam carne no Viandier

\begin{tabular}{|c|c|c|c|c|c|c|}
\hline RECEITA & $\begin{array}{l}\text { MODO DE } \\
\text { PREPARO } \\
\end{array}$ & ESPÉCIE & \multicolumn{4}{|c|}{$\begin{array}{c}\text { CONSTANTE NOS } \\
\text { MANUSCRITOS } \\
\end{array}$} \\
\hline Geleia de peixe ou carne & cozido & & VAL & $\mathrm{BN}$ & MAZ & VAT \\
\hline Lampreias frescas em molho apimentado & assado & lampreia & VAL & $\mathrm{BN}$ & & VAT \\
\hline Lampreia à galantina & cozido & lampreia & VAL & $\mathrm{BN}$ & MAZ & VAT \\
\hline Arroz fantasia & cozido & & VAL & $\mathrm{BN}$ & & VAT \\
\hline Lúcio & cozido & lúcio & VAL & $\mathrm{BN}$ & MAZ & VAT \\
\hline Lúcio pequeno & $\begin{array}{c}\text { assado } \\
\text { frito } \\
\end{array}$ & $\begin{array}{l}\text { lúcio } \\
\text { lúcio }\end{array}$ & VAL & $\mathrm{BN}$ & MAZ & VAT \\
\hline Barbos & $\begin{array}{c}\text { cozido } \\
\text { assado } \\
\text { frito } \\
\end{array}$ & $\begin{array}{l}\text { barbo } \\
\text { barbo } \\
\text { barbo } \\
\end{array}$ & VAL & $\mathrm{BN}$ & MAZ & VAT \\
\hline Robalo & cozido & robalo & VAL & $\mathrm{BN}$ & MAZ & VAT \\
\hline Sável & $\begin{array}{l}\text { cozido } \\
\text { assado }\end{array}$ & $\begin{array}{l}\text { sável } \\
\text { sável }\end{array}$ & & $\mathrm{BN}$ & MAZ & VAT \\
\hline Carpa & cozido & carpa & VAL & $\mathrm{BN}$ & MAZ & VAT \\
\hline Perca & $\begin{array}{l}\text { cozido } \\
\text { frito } \\
\end{array}$ & $\begin{array}{l}\text { perca } \\
\text { perca }\end{array}$ & VAL & $\mathrm{BN}$ & MAZ & VAT \\
\hline Tenca & $\begin{array}{c}\text { cozido } \\
\text { frito } \\
\text { assado } \\
\end{array}$ & & VAL & & MAZ & VAT \\
\hline Sargo de água doce (ou brema) & $\begin{array}{c}\text { cozido } \\
\text { assado } \\
\text { empada } \\
\end{array}$ & $\begin{array}{l}\text { sargo } \\
\text { sargo } \\
\text { sargo } \\
\end{array}$ & VAL & $\mathrm{BN}$ & MAZ & VAT \\
\hline Leucisco & $\begin{array}{c}\text { cozido } \\
\text { assado } \\
\text { frito } \\
\end{array}$ & $\begin{array}{l}\text { leucisco } \\
\text { leucisco } \\
\text { leucisco }\end{array}$ & VAL & $\mathrm{BN}$ & MAZ & VAT \\
\hline Enguias & cozido & enguia & VAL & $\mathrm{BN}$ & MAZ & VAT \\
\hline
\end{tabular}

${ }^{187}$ Já apresentadas nas duas tabelas anteriores. 


\begin{tabular}{|c|c|c|c|c|c|c|}
\hline & $\begin{array}{l}\text { assado } \\
\text { empada }\end{array}$ & $\begin{array}{l}\text { enguia } \\
\text { enguia }\end{array}$ & & & & \\
\hline Caboz & $\begin{array}{l}\text { cozido } \\
\text { assado } \\
\end{array}$ & $\begin{array}{l}\text { caboz } \\
\text { caboz }\end{array}$ & VAL & & MAZ & \\
\hline Truta & $\begin{array}{l}\text { cozida } \\
\text { empada }\end{array}$ & $\begin{array}{l}\text { truta } \\
\text { truta }\end{array}$ & VAL & $\mathrm{BN}$ & MAZ & VAT \\
\hline Pequenas enguias & assado & enguia & VAL & $\mathrm{BN}$ & MAZ & VAT \\
\hline Cadoz & $\begin{array}{c}\text { cozido } \\
\text { frito } \\
\end{array}$ & $\begin{array}{l}\text { cadoz } \\
\text { cadoz }\end{array}$ & VAL & & MAZ & VAT \\
\hline Gaymeaux & cozido & gaymeaux & VAL & $\mathrm{BN}$ & & VAT \\
\hline Alevinos & cozido & alevino & & & & VAT \\
\hline Filhotes de lampreia & $\begin{array}{l}\text { cozido } \\
\text { frito } \\
\text { empada }\end{array}$ & $\begin{array}{l}\text { lampreia } \\
\text { lampreia } \\
\text { lampreia }\end{array}$ & VAL & $\mathrm{BN}$ & MAZ & VAT \\
\hline Lampreias pequenas & $\begin{array}{l}\text { cozido } \\
\text { empada }\end{array}$ & $\begin{array}{l}\text { lampreia } \\
\text { lampreia }\end{array}$ & & & & VAT \\
\hline Alburno & cozido & alburno & VAL & $\mathrm{BN}$ & MAZ & VAT \\
\hline Lagostim & cozido & lagostim & VAL & $\mathrm{BN}$ & & VAT \\
\hline Golfinho & cozido & golfinho & VAL & $\mathrm{BN}$ & MAZ & VAT \\
\hline Cavala fresca & $\begin{array}{l}\text { assado } \\
\text { empada } \\
\text { cozido } \\
\end{array}$ & $\begin{array}{l}\text { cavala } \\
\text { cavala } \\
\text { cavala } \\
\end{array}$ & VAL & $\mathrm{BN}$ & MAZ & VAT \\
\hline $\begin{array}{l}\text { Robin do mar, } \\
\text { Robein vermelho, } \\
\text { Salmonete }\end{array}$ & $\begin{array}{l}\text { cozido } \\
\text { assado } \\
\text { empada }\end{array}$ & $\begin{array}{l}\text { robin do mar } \\
\text { robin } \\
\text { vermelho } \\
\text { salmonete } \\
\text { robin do mar } \\
\text { robin } \\
\text { vermelho } \\
\text { salmonete } \\
\text { robin do mar } \\
\text { robin } \\
\text { vermelho } \\
\text { salmonete } \\
\end{array}$ & VAL & $\mathrm{BN}$ & MAZ & VAT \\
\hline Congro & $\begin{array}{l}\text { cozido } \\
\text { assado }\end{array}$ & $\begin{array}{l}\text { congro } \\
\text { congro }\end{array}$ & VAL & $\mathrm{BN}$ & MAZ & VAT \\
\hline Merluza & frito & merluza & VAL & & MAZ & VAT \\
\hline Cação & cozido & cação & VAL & $\mathrm{BN}$ & MAZ & VAT \\
\hline Salmão fresco & $\begin{array}{l}\text { cozido } \\
\text { cozido } \\
\text { empada } \\
\end{array}$ & $\begin{array}{l}\text { salmão } \\
\text { salmão } \\
\text { salmão } \\
\end{array}$ & VAL & $\mathrm{BN}$ & MAZ & VAT \\
\hline Tainha & $\begin{array}{l}\text { assado } \\
\text { empada } \\
\text { cozido } \\
\end{array}$ & $\begin{array}{l}\text { cavala } \\
\text { cavala } \\
\text { cavala }\end{array}$ & VAL & $\mathrm{BN}$ & MAZ & VAT \\
\hline Bacalhau fresco & cozido & bacalhau & VAL & $\mathrm{BN}$ & MAZ & VAT \\
\hline
\end{tabular}




\begin{tabular}{|c|c|c|c|c|c|c|}
\hline Carne de baleia & cozido & baleia & VAL & & MAZ & VAT \\
\hline Bacalhau e hadoque & $\begin{array}{c}\text { cozido } \\
\text { cozido } \\
\text { frito } \\
\end{array}$ & $\begin{array}{l}\text { bacalhau } \\
\text { hadoque } \\
\text { hadoque }\end{array}$ & VAL & & MAZ & VAT \\
\hline Peixe-agulha & assado & peixe-agulha & & & & VAT \\
\hline Brecte & cozido & brecte & VAL & & MAZ & VAT \\
\hline Escamudo & cozido & bacalhau & & & & VAT \\
\hline Truta salmonada & cozido & $\begin{array}{c}\text { truta } \\
\text { salmonada } \\
\end{array}$ & VAL & & & VAT \\
\hline Solha & $\begin{array}{l}\text { cozido } \\
\text { cozido }\end{array}$ & $\begin{array}{l}\text { solha } \\
\text { solha }\end{array}$ & & $\mathrm{BN}$ & & VAT \\
\hline Linguado & cozido & linguado & & $\mathrm{BN}$ & & VAT \\
\hline Solha ou linguado & $\begin{array}{c}\text { cozido } \\
\text { cozido } \\
\text { assado } \\
\text { assado } \\
\text { frito } \\
\text { frito } \\
\end{array}$ & $\begin{array}{l}\text { linguado } \\
\text { solha } \\
\text { linguado } \\
\text { solha } \\
\text { linguado } \\
\text { solha } \\
\end{array}$ & & $\mathrm{BN}$ & MAZ & VAT \\
\hline Arraia & cozido & arraia & VAL & $\mathrm{BN}$ & MAZ & VAT \\
\hline Pregado & $\begin{array}{l}\text { cozido } \\
\text { cozido } \\
\end{array}$ & $\begin{array}{l}\text { pregado } \\
\text { pregado }\end{array}$ & VAL & $\mathrm{BN}$ & MAZ & VAT \\
\hline Rodovalho & cozido & rodovalho & & $\mathrm{BN}$ & & VAT \\
\hline Sargo & $\begin{array}{l}\text { cozido } \\
\text { assado } \\
\text { empada } \\
\end{array}$ & $\begin{array}{l}\text { sargo } \\
\text { sargo } \\
\text { sargo } \\
\end{array}$ & VAL & BN & MAZ & VAT \\
\hline Solha-Escura-do-Mar-do-Norte & $\begin{array}{l}\text { cozido } \\
\text { cozido }\end{array}$ & $\begin{array}{l}\text { solha-escura } \\
\text { solha-escura }\end{array}$ & VAL & & MAZ & VAT \\
\hline Tilápia Saint Peter & $\begin{array}{l}\text { cozido } \\
\text { assado } \\
\text { empada }\end{array}$ & $\begin{array}{l}\text { tilápia saint } \\
\text { peter } \\
\text { tilápia saint } \\
\text { peter } \\
\text { tilápia saint } \\
\text { peter } \\
\end{array}$ & VAL & & & VAT \\
\hline Truta salmonada & $\begin{array}{l}\text { cozido } \\
\text { assado } \\
\end{array}$ & $\begin{array}{c}\text { truta } \\
\text { salmonada } \\
\text { truta } \\
\text { salmonada }\end{array}$ & & & & VAT \\
\hline Sável & $\begin{array}{c}\text { assado } \\
\text { assado } \\
\text { frito } \\
\end{array}$ & $\begin{array}{l}\text { sável } \\
\text { sável } \\
\text { sável } \\
\end{array}$ & VAL & $\mathrm{BN}$ & MAZ & VAT \\
\hline Anchovas & $\begin{array}{l}\text { assado } \\
\text { assado } \\
\end{array}$ & $\begin{array}{l}\text { anchova } \\
\text { anchova }\end{array}$ & & $\mathrm{BN}$ & & VAT \\
\hline Eperlanos & $\begin{array}{l}\text { frito } \\
\text { frito } \\
\end{array}$ & $\begin{array}{l}\text { esperlanos } \\
\text { esperlanos } \\
\text { esperlanos }\end{array}$ & VAL & & MAZ & VAT \\
\hline Esturjão & cozido & esturjão & VAL & $\mathrm{BN}$ & MAZ & VAT \\
\hline Lula & frito & lula & VAL & $\mathrm{BN}$ & MAZ & VAT \\
\hline
\end{tabular}




\begin{tabular}{|c|c|c|c|c|c|c|}
\hline & cozido & lula & & & & \\
\hline Ostras & frito & ostras & & & & VAT \\
\hline Berbigões & frito & berbigão & VAL & $\mathrm{BN}$ & MAZ & VAT \\
\hline Mexilhões & cozido & mexilhão & VAL & $\mathrm{BN}$ & MAZ & VAT \\
\hline Lagostas & $\begin{array}{l}\text { cozido } \\
\text { assado }\end{array}$ & $\begin{array}{l}\text { lagosta } \\
\text { lagosta }\end{array}$ & & $\mathrm{BN}$ & & VAT \\
\hline
\end{tabular}




\subsubsection{A abolição dos interditos judeus}

As práticas alimentares diferenciavam-se no plano cultural e religioso, obedecendo a mecanismos que se aplicaram principalmente ao consumo de carne. A Europa católica de economia agropecuária, com suas florestas medidas em porcos, considerava esse animal um símbolo e a garantia de sua diferença ${ }^{188}$. Os interditos alimentares dos judeus e muçulmanos contribuíram para afirmar ainda mais a identidade cristã e de cada um desses grupos diante dela.

A abolição por parte dos cristãos dos interditos alimentares tradicionais dos judeus tem um significado maior do que parece à primeira vista. A Bíblia, em Atos dos Apóstolos 10, ensina que Cornélio, um centurião da corte Itálica, foi o primeiro estrangeiro convertido ao cristianismo. Tendo visto um anjo de Deus, este o instruiu que mandasse buscar Simão Pedro em Jope. Enquanto isso, Pedro teve uma visão descrita em Atos 10, versículos 9: 23:

9 E no dia seguinte, indo eles em seu caminho, e estando já perto da cidade,
subiu Pedro ao terraço para orar, quase à hora sexta. $10 \mathrm{E}$ tendo fome, quis
comer; e, enquanto lho preparavam, sobreveio-lhe um arrebatamento de
sentidos, 11 E viu o céu aberto, e que descia uma coisa, como se fosse uma
grande toalha segura pelas quatro pontas, e vindo para a terra. 12 Nela havia
de todos os animais quadrúpedes e répteis da terra, e aves do céu. 13 Uma
voz lhe falou: Levanta-te, Pedro, mata e come. 14 Pedro disse: De modo
algum, Senhor, porque nunca comi coisa alguma profana e impura. $15 \mathrm{E}$ a
voz lhe falou uma segunda vez: O que Deus purificou não chames tu de
impuro. 16 Isso aconteceu três vezes; e a toalha tornou a recolher-se ao céu
(BÍBLIA, Atos dos Apóstolos 10 9:23).

Enquanto refletia a respeito da visão, Pedro foi avisado pelo Espírito Santo que os homens de Cornélio o procuravam e que por Ele haviam sido enviados. Na casa de Cornélio, Pedro afirmou, no versículo 28: "Vós sabeis que é proibido a um judeu aproximar-se dum estrangeiro ou ir à sua casa. Todavia, Deus me mostrou que nenhum homem deve ser considerado profano ou impuro"; e nos versículos 34 e 35: "Em verdade, reconheço que Deus não faz distinção de pessoas, mas que em toda nação lhe é agradável aquele que o temer e fizer o que é justo”. No versículo 45 encontramos a seguinte afirmação: "Os fiéis da circuncisão, que tinham vindo com Pedro, profundamente se admiraram, vendo que o dom do Espírito Santo era derramado

${ }^{188}$ MONTANARI, Massimo. Modelos alimentares e identidades culturais. In: FLANDRIN, Jean Louis; MONTANARI, Massimo. (Org.). História da alimentação. Tradução Luciano Vieira Machado; Guilherme J. F. Teixeira. São Paulo: Estação Liberdade, 1998, p. 312-317. 
também sobre os pagãos". Ao voltar para Jerusalém, Pedro contou aos companheiros os detalhes de sua visão e da benção do Espírito Santo. Então, no versículo 18 temos: "depois de terem ouvido estas palavras, eles se calaram e deram glória a Deus, dizendo: 'Portanto também aos pagãos concedeu Deus o arrependimento que conduz à vida!'”.

Os animais purificados são símbolo de homens que podem se salvar acreditando em Cristo. Da mesma forma que o interdito alimentar marca a identidade cultural dos judeus, o não interdito é a marca do cristão, cuja salvação não depende da origem.

Já os interditos alimentares judeus são numerosos. $\mathrm{O}$ único invertebrado não proibido é a lagosta e toda a família dos répteis está excluída. Só podem ser consumidos os mamíferos de casco fendido ${ }^{189}$. Quanto às aves, a tradição rabínica dá uma lista de vinte espécies impuras, que inclui todas as aves de rapina. É preciso tirar todo o sangue do animal que vai ser consumido e a carne deve ser preparada (kasher ${ }^{190}$ ) com melihah. Não se pode comer o sebo, nem o tendão da coxa e é proibido alimentar-se de animais despedaçados por animais selvagens ${ }^{191}$.

A classificação dos animais em proibidos e autorizados está em dois capítulos bíblicos (Lev 11 e Dt 14), cuja proibição e autorização foram apresentadas por Moisés como revelações feitas pelo Senhor no Sinai. Os critérios se referem principalmente aos órgãos de locomoção para que se reconheçam animais puros: os terrestres devem ter o casco fendido e devem ruminar e os peixes devem ter barbatanas e escamas. Os animais puros deveriam se locomover. Estão proscritos os animais aquáticos que se fixam no fundo da água ou nas pedras e os terrestres desprovidos de patas. Além disso, as espécies são divididas em três grupos, segundo o meio em que vivem: terra, água e ar, criadas por Deus a partir de cada um dos elementos. Animal impuro é aquele que não respeita os planos de Deus: terrestres que não andam, aquáticos que não nadam e pássaros que não voam.

As diferenças também manifestam os desígnios do Criador e respeitá-las é um dever religioso: abolir distinções é um mal. O consumo da carne de um animal que oscila entre duas categorias atestaria cumplicidade com o Mal. O Livro de Gênesis afirma que "a tudo que é animado de vida, eu dou como alimento a relva verde" (Gn 1,

\footnotetext{
${ }^{189}$ Segundo Dolader, os judeus consumiam mais cordeiros do que os cristãos.

${ }^{190}$ Permitido, próprio ou bom.

${ }^{191}$ DOLADER, Miguel Angel Motis. A alimentação judia na Idade Média. In: FLANDRIN, Jean Louis; MONTANARI, Massimo. (Org.). História da alimentação. Tradução Luciano Vieira Machado; Guilherme J. F. Teixeira. São Paulo: Estação Liberdade, 1998, p. 364-365.
} 
30). Os carniceiros não foram previstos nos planos de Deus e são os mais impuros entre os animais.

Para se reconhecer um animal não carnívoro, o critério mais fácil é a ruminação. Os ruminantes mastigam duas vezes, por isso são considerados duplamente herbívoros e puros. Os suínos não ruminam e seu caráter impuro é confirmado por sua hibridez, pois comem vegetais e carne. Mas é difícil observar a ruminação de longe e, portanto, se fazia necessário um critério aplicável a animais selvagens, cujo regime alimentar não fosse bem conhecido, um critério anatômico observável num animal morto. $\mathrm{O}$ casco fendido, em vez de garras, impossibilita agarrar a presa ${ }^{192}$.

O direito canônico medieval, posteriormente, proibiu a carne de cavalo ${ }^{193}$ e de animais asfixiados ou mortos sem derramamento de sangue. ${ }^{194}$ Condenou também o consumo de carne proveniente de matadouros judeus. Mas muitas vezes a carne que não podia ser consumida pelos judeus (porque a pleura estava inflamada, porque o animal apresentou um defeito depois de abatido, ou porque, por erro, a carne ficou impregnada de sangue) era vendida a preços mais baixos e não há dúvida de que os cristãos consumiam essa carne rejeitada ${ }^{195}$.

\footnotetext{
${ }^{192}$ SOLER, Jean. As razões da Bíblia: regras alimentares hebraicas. In: FLANDRIN, Jean Louis; MONTANARI, Massimo. (Org.) História da alimentação. Tradução Luciano Vieira Machado; Guilherme J. F. Teixeira. São Paulo: Estação Liberdade, 1998, p. 80-91.

${ }^{193}$ Os interditos datam do século VIII, do pontificado de Gregório III (?-741 d.C.). O período coincide com a ascensão da cavalaria e a valorização do cavalo como patrimônio e símbolo de nobreza.

${ }^{194}$ LAURIOUX, Bruno. A Idade Média à mesa. Tradução Elsa Andringa. Sintra: Publicações EuropaAmérica, 1989, p. 14.

${ }^{195}$ DOLADER, Miguel Angel Motis. A alimentação judia na Idade Média. In: FLANDRIN, Jean Louis; MONTANARI, Massimo. (Org.) História da alimentação. Tradução Luciano Vieira Machado; Guilherme J. F. Teixeira. São Paulo: Estação Liberdade, 1998, p. 372.
} 


\subsubsection{Sobre o sacrifício}

A civilização cristã ocidental não sacrifica os animais como pré-requisito para o consumo de carne. Nela, tornou-se legítimo o consumo de animais sem o ritual religioso. A carne suplantou o pão e se convergiu no alimento símbolo do guerreiro, identificado com o caçador. Mas o pão, o vinho e o óleo se reabilitaram, graças à afirmação do Cristianismo e, paradoxalmente, os valores cristãos foram herdeiros das tradições romanas.

Os cristãos, ao mesmo tempo em que aboliram o sacrifício cruento, tornaram-se portadores de um novo sistema sacrificial, em que os ritos sacramentais afirmavam a primazia do pão e do vinho ${ }^{196}$. Ocorreu uma inversão e a carne passou a ocupar o lugar de alimento símbolo de status, ao mesmo tempo em que o pão, o azeite e o vinho passaram a ocupar o lugar sagrado. Além disso, o pão adquiriu uma simbologia ainda mais particular nesse ritual: a partir da consagração eucarística, ele representa a própria carne e o vinho, o próprio sangue.

Só conseguimos ter alguma ideia dos ritos sacrificiais mais antigos por meio de documentos literários, que quase sempre são vagos e incompletos. Mas pode-se afirmar que a eliminação do caráter sagrado, puro ou impuro, é o elemento primitivo do sacrifício $^{197}$.

Robertson Smith (1875-89 e 1889), o primeiro a tentar uma explicação racional para o sacrifício, identificou sua raiz nas práticas do culto totêmico e no clã totêmico árabe e semítico. O totem é parente de seus adoradores, possuindo a mesma carne e sangue, e o ritual garantiria essa vida comum que os anima e os associa. A morte sacrificial buscava tornar lícito o consumo de um animal sagrado, pois ao comer o totem, o homem a ele se assemelha. O sacrifício totêmico era um rito expiatório, como Smith considera todos os sacrifícios, e a expiação restabelecia uma aliança rompida. $\mathrm{O}$ sacrifício humano substituiu o animal quando o parentesco entre homens e animais tornou-se ininteligível aos semitas. Era a troca direta de sangue entre o deus e o humano, a única possível. Pouco a pouco o caráter sagrado dos animais, consumidos diariamente, teria desaparecido e, dessa forma, a vítima se assemelhou ao homem,

\footnotetext{
${ }^{196}$ MONTANARI, Massimo. Romanos, bárbaros e cristãos: na aurora da cultura alimentar europeia. In: FLANDRIN, Jean Louis; MONTANARI, Massimo. (Org.). História da alimentação. Tradução Luciano Vieira Machado; Guilherme J. F. Teixeira. São Paulo: Estação Liberdade, 1998, p. 178-281.

${ }^{197}$ MAUSS, Marcel; HUBERT, Henri. Sobre o sacrifício. Tradução Paulo Neves. São Paulo: Cosac Naif, 2005, p. 13 e 14.
} 
constituindo cada vez mais uma oferenda, uma dádiva humana a seu deus. Sacrifícios expiatórios são geralmente seguidos de uma reconciliação com o deus. A refeição sacrificial, a asperção de sangue e a unção restabeleceriam a aliança. Robertson Smith identifica nos próprios ritos comunais a virtude purificadora e, dessa forma, estabelece a idéia de expiação absorvida na idéia de comunhão. ${ }^{198}$.

James George Frazer reconheceu a semelhança entre os totens sacrificados e os demônios agrários. Demonstrou como o sacrifício agrário adviria da refeição comunal. O velho deus sacrificado, desempenhando o papel expiatório, parecia levar consigo a doença, a morte, o pecado, embora a expiação ainda viesse da comunhão ${ }^{199}$.

Convém lembrar que o totemismo só aparece em estado puro em algumas tribos da Austrália e América, e, portanto, tais sistemas explicativos são bastante arbitrários e propõem uma hipótese não passível de verificação.

Tylor (1876-78, II, cap. XVIII) também imaginou uma gênese das formas de sacrifício. Este seria uma dádiva feita pelos selvagens a seres sobrenaturais, para estabelecer uma ligação. As dádivas garantiriam ao fiel direitos sobre seu deus. Quando, posteriormente, os deuses se afastaram dos homens, estabeleceram-se os ritos sacrificiais, para que as dádivas continuassem a ser transmitidas e chegassem até esses seres espirituais. O que era dádiva tornou-se homenagem, e o fiel já não esperava mais qualquer retorno. O passo seguinte foi o sacrifício tornar-se abnegação e renúncia. A evolução teria transformado os presentes do selvagem no sacrifício em $\mathrm{si}^{200}$.

A sociedade grega clássica estabelecia e mantinha relação com o poder divino através da prática sacrificial ritualizada e diária de animais, cuja carne era consumida de acordo com restrições precisas. Nenhum empreendimento político, militar ou social poderia ser exercido sem a prática sacrificial, seguida da consequente refeição ${ }^{201}$. A relação com os animais era estabelecida através do consumo da carne, que chegava aos humanos sempre através do deus, e por isso precisava ser tratada de maneira ritual, com o devido respeito, dentro de um contexto religioso. Abate, religião e cozinha eram combinados no que os gregos chamavam thusia, ou sacrifício.

\footnotetext{
${ }^{198}$ SMITH, Willian Robertson. The Religion of the Semites. New Jersey: Transaction Publishers, 2002, passim.

${ }^{199}$ FRAZER, James George. The golden bought. New Jersey: Summit Classic Press, 2012, passim.

${ }^{200}$ TYLOR, Edward Burnett. Primitive culture. Charleston: Nabu Press, 2010, passim.

201 DETIENNE, Marcel. Culinary pratices and the spirit of sacrifice. In: DETIENNE, Marcel; VERNANT, Jean-Pierre. The Cuisine of sacrifice among the greeks. Translation Paula Eissing. Chicago and London: The University of Chicago Press, 1989, p. 1-3.
} 
Assim como na Grécia, em Roma o consumo de carne estava vinculado a práticas religiosas sacrificiais. Com tais ritos os romanos definiam sua identidade de homens civilizados, membros de uma comunidade social e legitimavam sua relação com a terra $^{202}$. O pão, o azeite e o vinho (vegetais cultivados) eram os alimentos signos da civilização romana e a "bestialidade" dos povos bárbaros era identificada a partir de seu sistema alimentar, que se baseava mais na exploração de recursos naturais do que na agricultura, privilegiando a caça e a criação em semiliberdade. Era uma civilização da carne, leite e manteiga, oposta à do pão, vinho e óleo ${ }^{203}$. O vinho era indispensável nos sacrifícios romanos, eventos principais dos cerimoniais religiosos. Mas não era bebida sagrada, apenas mais um alimento, servido junto com a carne nos banquetes.

Henri Hubert e Marcel Mauss propuseram a comunicação entre o sagrado e o profano como o mecanismo central do sacrifício. A vítima sacrificial é a mediadora entre o sacrificador e a divindade, tendo em vista um processo de mão dupla, complementar, em que a sacralização da vítima liga o sacrificador ao sagrado e, ao mesmo tempo, a dessacralização separa o sacrificador da divindade e qualquer possibilidade de uma possível aproximação de perigo. O sacrifício estabeleceria ao mesmo tempo a aproximação e a separação necessárias entre o sagrado e o profano. Essa relação sacrificial traria vantagens à coletividade e aos indivíduos, à norma social e à civilização ${ }^{204}$.

Hegel considerou que pelo ato sacrificial o deus toma consciência do $e u$, ao mesmo tempo em que o ego se torna consciente do deus ${ }^{205}$. E Emile Durkheim identificou nas proibições, inibições, práticas que objetivavam o desconforto, abstinências, privações, sofrimentos e renúncias do ascetismo, um papel integral em toda cultura humana: sem o sacrifício a religião não é possível ${ }^{206}$.

\footnotetext{
${ }^{202}$ DUPONT, Florence. Gramática da alimentação e das refeições romanas. In: FLANDRIN, Jean Louis; MASSIMO, Montanari. (Org.). História da alimentação. Tradução Luciano Vieira Machado; Guilherme J. F. Teixeira. São Paulo: Estação Liberdade, 1998, p. 199-216.

${ }^{203}$ MONTANARI, Massimo. Romanos, bárbaros e cristãos: na aurora da cultura alimentar européia. In: FLANDRIN, Jean Louis; MONTANARI, Massimo. (Org.). História da alimentação. Tradução Luciano Vieira Machado; Guilherme J. F. Teixeira. São Paulo: Estação Liberdade, 1998, p. 178-281.

${ }^{204}$ MAUSS, Marcel; HUBERT, Henri. Sobre o sacrificio. Tradução Paulo Neves. São Paulo: Cosac Naif, 2005, passim.

${ }^{205}$ CASSIRER, Ernst. The problem of knowledge: philosophy, science, and history since Hegel. Translated: Willian W. Woglom; Charles H. Hendel. Disponível em: $<$ http://www.questia.com/read/56851373/the-problem-of-knowledge-philosophy-science-and $>$. Acesso em: 10 out. 2012.

${ }^{206}$ DURKHEIM, Emile. As formas elementares da vida religiosa. Tradução Paulo Neves. São Paulo: Martins Editora, 2003, p. 60-69.
} 
No Cristianismo, o sacrifício repetido regularmente na Eucaristia é pedra-detoque da eficácia religiosa ${ }^{207}$. Mas a morte de animais perdeu o significado religioso que possui em outras culturas e foi excluída da esfera do sagrado e desprovida de significado, uma vez que somente um sacrifício é possível, no qual a divindade é a única vítima aceitável. ${ }^{208}$. A eucaristia é a imagem do sacrifício voluntário em nome de um bem maior, feito de maneira consciente e com aceitação. O Deus-sacrificado é o símbolo daquele que consegue antever e compreender a necessidade da submissão para expiação e cumprimento de um desígnio superior, e da espera serena desse desígnio. Somente através desse ascetismo seria possível sentir o que é capaz de sustentar quando nada mais sustenta, ou seja, a fé verdadeira, a confiança no Outro superior sem resistência.

${ }^{207}$ SMITH, Willian Robertson. The religion of the semites. New Jersey: Transaction Publishers, 2002, passim.

${ }^{208}$ DURAND, Jean-Louis. Culinary pratices and the spirit of sacrifice. In: DETIENNE, Marcel; VERNANT, Jean-Pierre. The cuisine of sacrifice among the greeks. Translation Paula Eissing. Chicago and London: The University of Chicago Press, 1989, p. 87-105. 


\subsection{Carne, cozinha e dietética}

A arte gastronômica do final da Idade Média foi portadora de um discurso socialmente significativo por sua forte conotação social em correlação com a ciência dietética, com a qual caminhou junto. A cultura medieval identificou essas exigências não como atributos de pessoa, e sim de grupo.

Houve uma evolução lenta e progressiva na culinária aristocrática, a partir do final da Antiguidade e ao longo da Idade Média. Mas durante a Alta Idade Média ainda perdurava a herança da Antiguidade. Já no século XIII, os livros de cozinha não apresentavam quase nada em comum com a compilação de Apicius, do século IV. O uso do garum $^{209}$, por exemplo, foi gradualmente abandonado ${ }^{210}$, assim como o hábito de comer deitado, que privilegiava uma cozinha baseada em picados e almôndegas, substituídos pelos cortes de carne especializados, que valorizavam e honravam o trinchante ${ }^{211}$.

Bruno Laurioux acredita que a utilização de livros de cozinha foi interrompida na Alta Idade Média para ressurgir no final desse período, devido à reunião das ars mecanicae, das ars coquinaria, ao interesse dos médicos pela alimentação e a necessidade de normatizá-la, e à ascensão social da figura do cozinheiro, elevado a mestre de cozinha ${ }^{212}$. Na Alta Idade Média a atividade médica em sua vertente dietética está relacionada diretamente com a culinária. Comida poderia designar grupos de alimentos de determinado valor nutricional, usos culturais e valores emocionais ${ }^{213}$. Até o século XIII, as palavras coquina ou culina referiam-se, em fontes textuais, ao espaço de cozinhar. Talvez a cozinha fosse um lugar para o qual afluíam conhecimentos diversos, em que matérias primas eram transformadas. É apenas a partir de então que o sentido de cibaria cocta, comida preparada, passa a ser utilizado ${ }^{214}$. Jack Goody,

\footnotetext{
${ }^{209}$ Molho de peixe semelhante ao nuoc-mam vietnamita, usado na Roma antiga para temperar a maior parte dos pratos.

${ }^{210}$ A cozinha de Bizâncio, que usava bastante azeite, e no século X ainda fazia largo uso do garum, não influenciou de forma significativa a culinária ocidental.

${ }^{211}$ LAURIOUX, Bruno. A Idade Média à mesa. Tradução Elsa Andringa. Sintra: Publicações EuropaAmérica, 1989, p. 12. 212212 Idem, 1997, p. 28.

${ }^{213}$ CONTRERAS, Jesús. Los aspectos culturales em el consume de carne. In: ARNAIZ, Mabel Garcia. (Coord.). Somos lo que comemos: estúdios de alimentación y cultura em España. Barcelona: Ariel, 2002, p. 222.

${ }^{214}$ ASFORA, Wanessa. Apício: história da incorporação de um livro de cozinha na Alta Idade Média (séculos VIII e IX). 2009. 272 f. Dissertação (Mestrado em História Social) - Faculdade de Filosofia, Letras e Ciências Humanas, Universidade de São Paulo, São Paulo, 2009.
} 
propôs três sentidos para o vocábulo "cozinha": o sentido ligado ao espaço (kitchen), o relativo a uma cultura diferenciada (cuisine) e o que designa formas de cozinhar elaboradas, utilizado como sinônimo de gastronomia ${ }^{215}$.

Desde o século $\mathrm{V}$, os manuais de dietética passaram a dedicar atenção especial à carne. O De observatione ciborum, de Antimo, que viveu na corte de Ravena do rei godo Teodorico (454-526.), apesar de ser grego de origem, concentra-se sobretudo nas carnes, especialmente na carne de porco, assada, cozida, ao forno, ensopada, e o capítulo mais longo da obra trata do toucinho. Mas trata também de outras carnes como vaca, boi, ovelha, carneiro, cabrito, cabriola, cervo, javali, lebre, faisão, perdiz, pombo, pavão, galinha e ganso. ${ }^{216}$.

Antes de ter sido terapêutico, o conhecimento médico medieval era um saber teórico fundado na filosofia aristotélica aprimorada pelo grego Galeno (ca.129-199 d.C.). Conservou de Aristóteles, especialmente do Tratado da Alma, a fisiologia e a psicologia que dava conta da fauna, da flora e do homem. O homem estava no coração do universo criado e a ele se aplicavam os mesmos princípios do mundo físico. Os movimentos dos planetas conferiam uma justificativa científica para a astrologia e o horóscopo. O jogo dos elementos e dos humores estabelecia a compleição de cada indivíduo: sanguíneo, bilioso, fleumático ou melancólico. E as funções da alma, vegetativa, cognitiva ou racional, permitiam aproveitar a continuidade e as hierarquias do universo biológico e o laço orgânico da alma e do corpo. Os médicos ficaram a salvo das críticas dos teólogos ao adotarem uma deontologia que subordinava a preocupação com a saúde corporal à saúde da alma ${ }^{217}$.

A dietética mantinha a base da patologia humoral, segundo a qual as funções corporais eram reguladas pelos fluidos (humores) sangue (haima), muco (phlegma), bílis amarela (cholera) e bílis negra (melancholia), com qualidades derivadas dos elementos fogo, água, terra e ar. O sangue era considerado quente e úmido; a fleuma, fria e úmida; a bílis amarela, quente e seca; e a bílis negra, fria e seca. A patologia humoral diferenciava assim quatro tipos de pessoa: sanguíneas, fleumáticas, coléricas e melancólicas. A alimentação deveria buscar a restauração do equilíbrio dos humores e, de acordo com o tipo humano, cada alimento poderia produzir um efeito diferente.

\footnotetext{
${ }^{215}$ GOODY, Jack. Cooking, cuisine and class. Cambridge: CUP, 1982.

216 MONTANARI, Massimo. A fome e a abundância: história da alimentação na Europa. Tradução Andréa Doré. Edusc: São Paulo, 2003, p. 27-28.

${ }^{217}$ VERGER, Jacques Homens e saber na Idade Média. Tradução Carlota Boto. Bauru: EDUSC, 1999, p. 36 e 49.
} 
A concepção do bispo Isidoro de Sevilha (ca. 560-636 d.C.), originária da teoria dos humores de Galeno, em Etimologia, afirmava que a medicina não era necessariamente medicação, e que tratar era restaurar a energia vital, verdadeiro agente de cura, perdurou por toda a Idade $\mathrm{Média}^{218}$. A terapêutica apoiada na dietética implicava na gestão racional e cotidiana do corpo e seu principal meio era o regime alimentar.

Como se pode observar em $O$ regime do corpo, de Aldebrandino de Siena, século XIII, os médicos separavam muito nitidamente o que seria uma dieta de doentes de um regime para os sadios $^{219}$. Os doentes deviam comer alimentos que corrigissem calor ou frio, sequidão ou umidade excessivos, mesmo que para os sãos tais alimentos fossem considerados verdadeiro veneno. Já os saudáveis deveriam fortalecer a compleição específica de cada indivíduo: os quentes deveriam comer alimentos quentes, os frios, coisas frias.

Toda casa nobre estava vinculada a pelo menos um médico que necessariamente estava familiarizado com a doutrina usual. Um trabalho do começo do século XIV indica que a prática culinária naquele tempo deve ter sido determinada pela medicina teórica contemporânea. Quando, em meados de 1332, o médico e doutor Magninus Mediolanensis (Maino de' Maineri) compôs seu Regimen sanitatis, dedicou uma série de três capítulos, na sua Parte 3, a um sistemático exame das qualidades de todos os gêneros alimentícios, geralmente em uso nas casas das pessoas. Para essa análise, Magninus certamente estava em dívida com a tradição galênica, uma vez que o corpo dessa teoria distingue as qualidades nutritivas e humorais de cada espécie de grão, vegetal, fruta, animal e produto animal. Embora esse trabalho, nesse aspecto, se assemelhe a um número similar de esboços compilados nos séculos XII e XIII, ele é notável pelo detalhe e profundidade de seu exame dos gêneros alimentícios. Para um interessado na cozinha do final da Idade Média, a obra é preciosa porque contém um capítulo intitulado De saporibus et condimentis, no qual o médico define a função medicinal dos molhos culinários e, a partir dessa função, enumera extensamente os molhos apropriados para uma variedade de carnes e peixes ${ }^{220}$.

\footnotetext{
${ }^{218}$ POUCHELLE, Marie C. Medicina. Tradução Mario Jorge da Motta Bastos. In: LE GOFF, Jacques; SCHMITT, Jean-Claude. (Org.). Dicionário temático do Ocidente Medieval. São Paulo: Edusc, v. 2, 2006, p. 151-166.

219 FLANDRIN, Jean-Louis. A distinção pelo gosto. In: ARIÉS, Philippe; DUBY, Georges. (Dir.). História da vida privada: da Renascença ao século das luzes. Tradução Hildegard Feist. São Paulo: Companhia das Letras, v. 3, 2009, p. 291.

${ }^{220}$ SCULLY, Terence. The Viandier of Taillevent. Ottawa: University of Ottawa Press, 1988, passim.
} 
Magninus afirmou, ainda, que os condimentos serviam, originalmente, para tornar os alimentos mais palatáveis e, portanto, mais digestivos. Entretanto, de acordo com ele, molhos desempenhavam um papel muito mais importante no regime de qualquer homem saudável: eles trabalhariam para neutralizar qualquer agressão desnecessária dos gêneros alimentícios a serem consumidos, ajudariam a fazer a digestão de vários alimentos de maneira fácil e segura. Uma premissa fundamental para o uso de condimentos é: "Molhos variam de acordo com os alimentos para os quais são feitos, porque este ou aquele alimento requer este ou aquele molho, como os maiores cozinheiros sabem". Os cozinheiros dos grandes lordes tinham que estar atentos para as qualidades humorais de todos os gêneros alimentícios que passavam por suas mãos. Eles sabiam o que era seguro ingerir e reconheciam que combinação de ingredientes, carnes e molhos era adequada para a saúde do senhor e de sua corte.

Por essa razão, o método empregado para cozinhar qualquer carne ou peixe precisava ser apropriado. No processo de elaboração, a exposição à umidade e ao calor tende a aumentar ou diminuir a natural umidade relativa do alimento e também a moderar ou intensificar seu relativo calor. O princípio que os médicos medievais prescreviam era simplesmente que carnes secas poderiam ser fervidas e carnes úmidas deveriam ser assadas.

Apresentamos a seguir uma tabela que demonstra de que forma, quanto ao preparo, se apresentam no Viandier as receitas (considerando apenas as anteriores ao século $\mathrm{XV}$ ) que utilizam carne como seu ingrediente principal, conforme e quando especificado $^{221}$ :

Tabela 9 - Receitas que apresentam carne no Viandier

\begin{tabular}{|c|c|c|c|c|c|c|c|c|}
\hline RECEITA & SEÇÃO & $\begin{array}{l}\text { MODO DE } \\
\text { PREPARO }\end{array}$ & $\begin{array}{l}\text { TIPO DE } \\
\text { CARNE }\end{array}$ & ESPÉCIE & \multicolumn{4}{|c|}{$\begin{array}{c}\text { CONSTANTE NOS } \\
\text { MANUSCRITOS }\end{array}$} \\
\hline Fervura de carne gorda & Sopas gordas & Cozido & quadrúpede & $\begin{array}{c}\text { vaca } \\
\text { porco } \\
\text { carneiro }\end{array}$ & & $\mathrm{BN}$ & MAZ & VAT \\
\hline Retalhado de carneiro & Sopas gordas & Cozido & quadrúpede & carneiro & & $\mathrm{BN}$ & MAZ & VAT \\
\hline Carnes entremeadas & Sopas gordas & Cozido & quadrúpede & & $\mathrm{VAL}$ & $\mathrm{BN}$ & MAZ & VAT \\
\hline Veadada de veado fresco & Sopas gordas & $\begin{array}{l}\text { Cozido } \\
\text { Empada }\end{array}$ & quadrúpede & veado & VAL & & MAZ & VAT \\
\hline Javali & Sopas gordas & $\begin{array}{l}\text { cozido } \\
\text { cozido }\end{array}$ & $\begin{array}{l}\text { quadrúpede } \\
\text { quadrúpede }\end{array}$ & $\begin{array}{l}\text { javali } \\
\text { veado }\end{array}$ & VAL & $\mathrm{BN}$ & MAZ & VAT \\
\hline
\end{tabular}

${ }^{221}$ Essa tabela já foi apresentada no neste trabalho, no item 1.2.1. A importância social. 


\begin{tabular}{|c|c|c|c|c|c|c|c|c|}
\hline Cabra selvagem & Sopas gordas & $\begin{array}{l}\text { cozido } \\
\text { empada }\end{array}$ & quadrúpede & cabra & VAL & $\mathrm{BN}$ & MAZ & \\
\hline Capões ou vitela com ervas & Sopas gordas & $\begin{array}{l}\text { cozido } \\
\text { cozido }\end{array}$ & $\begin{array}{c}\text { ave } \\
\text { quadrúpede } \\
\end{array}$ & $\begin{array}{l}\text { capão } \\
\text { vitela }\end{array}$ & & $\mathrm{BN}$ & & VAT \\
\hline Caldo quente de porco & Sopas gordas & cozido & quadrúpede & porco & $\mathrm{VAL}$ & $\mathrm{BN}$ & MAZ & VAT \\
\hline Cretonada de ervilhas & Sopas gordas & cozido & ave & galinha & $\mathrm{VAL}$ & $\mathrm{BN}$ & MAZ & VAT \\
\hline Cretonada de favas & Sopas gordas & cozido & ave & galinha & & $\mathrm{BN}$ & MAZ & VAT \\
\hline Cuminade de aves & Sopas gordas & cozido & ave & & $\mathrm{VAL}$ & $\mathrm{BN}$ & MAZ & VAT \\
\hline Cuminade de amêndoas & Sopas gordas & cozido & ave & & VAL & $\mathrm{BN}$ & & VAT \\
\hline Caldo de canela & Sopas gordas & $\begin{array}{l}\text { cozido } \\
\text { cozido } \\
\end{array}$ & $\begin{array}{c}\text { ave } \\
\text { quadrúpede }\end{array}$ & & VAL & $\mathrm{BN}$ & MAZ & VAT \\
\hline Caldo georgié & Sopas gordas & cozido & ave & doméstica & $\mathrm{VAL}$ & $\mathrm{BN}$ & MAZ & VAT \\
\hline Caldo ruivo & Sopas gordas & $\begin{array}{l}\text { cozido } \\
\text { cozido } \\
\end{array}$ & $\begin{array}{c}\text { quadrúpede } \\
\text { ave }\end{array}$ & & VAL & $\mathrm{BN}$ & MAZ & VAT \\
\hline Vísceras de porco & Sopas gordas & cozido & quadrúpede & porco & VAL & $\mathrm{BN}$ & MAZ & VAT \\
\hline Molho de pássaros & Sopas gordas & cozido & ave & & $\mathrm{VAL}$ & $\mathrm{BN}$ & MAZ & VAT \\
\hline Caldo branco de capões & Sopas gordas & cozido & ave & capão & $\mathrm{VAL}$ & $\mathrm{BN}$ & MAZ & VAT \\
\hline $\begin{array}{l}\text { Aferventado de lebres } \\
\text { ou coelhos }\end{array}$ & Sopas gordas & $\begin{array}{l}\text { cozido } \\
\text { cozido } \\
\end{array}$ & $\begin{array}{l}\text { quadrúpede } \\
\text { quadrúpede } \\
\end{array}$ & $\begin{array}{c}\text { lebre } \\
\text { coelho } \\
\end{array}$ & VAL & $\mathrm{BN}$ & MAZ & VAT \\
\hline Aferventado de capões & Sopas gordas & cozido & ave & capão & $\mathrm{VAL}$ & $\mathrm{BN}$ & MAZ & VAT \\
\hline $\begin{array}{l}\text { Caldo alemão de coelhos } \\
\text { ou aves }\end{array}$ & Sopas gordas & $\begin{array}{l}\text { cozido } \\
\text { cozido } \\
\end{array}$ & $\begin{array}{c}\text { quadrúpede } \\
\text { ave }\end{array}$ & coelho & VAL & $\mathrm{BN}$ & MAZ & VAT \\
\hline Mexido de aves & Sopas gordas & cozido & ave & & VAL & $\mathrm{BN}$ & MAZ & VAT \\
\hline Rápido caldo inglês & Sopas gordas & cozido & quadrúpede & porco & $\mathrm{VAL}$ & $\mathrm{BN}$ & MAZ & VAT \\
\hline Caldo de agraço & Sopas gordas & $\begin{array}{l}\text { cozido } \\
\text { cozido } \\
\end{array}$ & $\begin{array}{c}\text { quadrúpede } \\
\text { ave }\end{array}$ & & VAL & $\mathrm{BN}$ & & VAT \\
\hline Caldo amarelo-verde & Sopas gordas & $\begin{array}{l}\text { cozido } \\
\text { cozido } \\
\end{array}$ & $\begin{array}{c}\text { quadrúpede } \\
\text { ave }\end{array}$ & & VAL & $\mathrm{BN}$ & MAZ & VAT \\
\hline Rappé & Sopas gordas & $\begin{array}{l}\text { cozido } \\
\text { cozido } \\
\end{array}$ & $\begin{array}{c}\text { quadrúpede } \\
\text { ave }\end{array}$ & & VAL & $\mathrm{BN}$ & MAZ & VAT \\
\hline Guisado de vitela & Sopas gordas & cozido & quadrúpede & vitela & $\mathrm{VAL}$ & $\mathrm{BN}$ & MAZ & VAT \\
\hline Guisado de lebres & Sopas gordas & cozido & quadrúpede & lebre & $\mathrm{VAL}$ & $\mathrm{BN}$ & MAZ & VAT \\
\hline Guisado de coelhos & Sopas gordas & cozido & quadrúpede & coelho & & $\mathrm{BN}$ & & VAT \\
\hline Porco assado & Carnes Assadas & $\begin{array}{l}\text { assado } \\
\text { empada }\end{array}$ & $\begin{array}{l}\text { quadrúpede } \\
\text { quadrúpede }\end{array}$ & $\begin{array}{l}\text { porco } \\
\text { porco }\end{array}$ & VAL & $\mathrm{BN}$ & MAZ & VAT \\
\hline Vitela assada & Carnes Assadas & $\begin{array}{l}\text { assado } \\
\text { empada }\end{array}$ & $\begin{array}{l}\text { quadrúpede } \\
\text { quadrúpede }\end{array}$ & $\begin{array}{l}\text { vitela } \\
\text { vitela }\end{array}$ & & $\mathrm{BN}$ & MAZ & VAT \\
\hline Desfiado de bezerro & Carnes Assadas & frito & quadrúpede & bezerro & $\mathrm{VAL}$ & $\mathrm{BN}$ & MAZ & VAT \\
\hline Carneiro assado & Carnes Assadas & assado & quadrúpede & carneiro & VAL & $\mathrm{BN}$ & MAZ & VAT \\
\hline Cabras novas, cordeiros & Carnes Assadas & assado & $\begin{array}{l}\text { quadrúpede } \\
\text { quadrúpede }\end{array}$ & $\begin{array}{c}\text { cordeiro } \\
\text { cabra }\end{array}$ & VAL & $\mathrm{BN}$ & MAZ & VAT \\
\hline Gansos & Carnes Assadas & assado & ave & ganso & VAL & $\mathrm{BN}$ & MAZ & VAT \\
\hline Galinhas assadas & Carnes Assadas & $\begin{array}{l}\text { assado } \\
\text { empada }\end{array}$ & $\begin{array}{l}\text { ave } \\
\text { ave }\end{array}$ & $\begin{array}{l}\text { galinha } \\
\text { galinha } \\
\end{array}$ & VAL & $\mathrm{BN}$ & MAZ & VAT \\
\hline Capões, galinhas e galos & Carnes Assadas & assado & ave & $\begin{array}{c}\text { capão } \\
\text { galinha } \\
\text { galo }\end{array}$ & VAL & $\mathrm{BN}$ & MAZ & VAT \\
\hline Coelhos assados & Carnes Assadas & $\begin{array}{l}\text { assado } \\
\text { empada }\end{array}$ & $\begin{array}{l}\text { quadrúpede } \\
\text { quadrúpede }\end{array}$ & $\begin{array}{l}\text { coelho } \\
\text { coelho }\end{array}$ & VAL & $\mathrm{BN}$ & MAZ & VAT \\
\hline Capões gordurosos & Carnes Assadas & assado & ave & capão & & & & VAT \\
\hline Lebres assadas & Carnes Assadas & $\begin{array}{r}\text { assado } \\
\text { empada }\end{array}$ & $\begin{array}{l}\text { quadrúpede } \\
\text { quadrúpede }\end{array}$ & $\begin{array}{l}\text { lebre } \\
\text { lebre }\end{array}$ & VAL & $\mathrm{BN}$ & MAZ & VAT \\
\hline Atoleiro de javali fresco & Carnes Assadas & assado & quadrúpede & javali & $\mathrm{VAL}$ & $\mathrm{BN}$ & MAZ & VAT \\
\hline
\end{tabular}




\begin{tabular}{|c|c|c|c|c|c|c|c|c|}
\hline Todos os veados frescos & Carnes Assadas & assado & quadrúpede & veado & & $\mathrm{BN}$ & MAZ & VAT \\
\hline Pombas assadas & Carnes Assadas & $\begin{array}{r}\text { assado } \\
\text { empada }\end{array}$ & $\begin{array}{l}\text { ave } \\
\text { ave }\end{array}$ & $\begin{array}{l}\text { pomba } \\
\text { pomba }\end{array}$ & VAL & $\mathrm{BN}$ & & VAT \\
\hline Pássaros pequenos & Carnes Assadas & $\begin{array}{l}\text { assado } \\
\text { empada }\end{array}$ & $\begin{array}{l}\text { ave } \\
\text { ave }\end{array}$ & $\begin{array}{l}\text { pássaros } \\
\text { pequenos } \\
\text { pássaros } \\
\text { pequenos }\end{array}$ & VAL & $\mathrm{BN}$ & MAZ & VAT \\
\hline Carambolas e galinholas & Carnes Assadas & $\begin{array}{l}\text { assado } \\
\text { empada }\end{array}$ & $\begin{array}{l}\text { ave } \\
\text { ave }\end{array}$ & $\begin{array}{l}\text { carambola } \\
\text { galinhola } \\
\text { carambola } \\
\text { galinhola } \\
\end{array}$ & & $\mathrm{BN}$ & & VAT \\
\hline Perdiz & Carnes Assadas & $\begin{array}{l}\text { assado } \\
\text { empada }\end{array}$ & $\begin{array}{l}\text { ave } \\
\text { ave }\end{array}$ & $\begin{array}{l}\text { perdiz } \\
\text { perdiz } \\
\end{array}$ & VAL & $\mathrm{BN}$ & MAZ & VAT \\
\hline Rolas & Carnes Assadas & $\begin{array}{l}\text { assado } \\
\text { empada }\end{array}$ & $\begin{array}{l}\text { ave } \\
\text { ave }\end{array}$ & $\begin{array}{l}\text { rola } \\
\text { rola }\end{array}$ & & $\mathrm{BN}$ & & VAT \\
\hline Cisnes & Carnes Assadas & assado & ave & cisne & VAL & $\mathrm{BN}$ & MAZ & VAT \\
\hline Pavões & Carnes Assadas & assado & ave & pavão & VAL & $\mathrm{BN}$ & MAZ & VAT \\
\hline Faisões & Carnes Assadas & assado & ave & faisão & VAL & $\mathrm{BN}$ & MAZ & VAT \\
\hline Cegonhas & Carnes Assadas & assado & ave & cegonha & VAL & $\mathrm{BN}$ & MAZ & VAT \\
\hline Garças-reais & Carnes Assadas & assado & ave & garça & VAL & $\mathrm{BN}$ & MAZ & VAT \\
\hline Pato-real do rio & Carnes Assadas & assado & ave & pato do rio & VAL & $\mathrm{BN}$ & MAZ & VAT \\
\hline Abetardos, gansos e grous & Carnes Assadas & assado & ave & $\begin{array}{l}\text { abetardo } \\
\text { ganso } \\
\text { selvagem } \\
\text { grou } \\
\end{array}$ & VAL & $\mathrm{BN}$ & MAZ & VAT \\
\hline Alcaravões & Carnes Assadas & assado & ave & alcavarão & & $\mathrm{BN}$ & & VAT \\
\hline Cormorões & Carnes Assadas & assado & ave & cormorão & VAL & $\mathrm{BN}$ & MAZ & VAT \\
\hline Colhereiros & Carnes Assadas & assado & ave & colheiro & & & & VAT \\
\hline Marrequinho & Carnes Assadas & assado & ave & marrequinho & & & & VAT \\
\hline $\begin{array}{l}\text { Leitão recheado } \\
\text { Falso grenon }\end{array}$ & $\begin{array}{l}\text { Carnes Assadas } \\
\text { Entremezes }\end{array}$ & $\begin{array}{l}\text { assado } \\
\text { cozido } \\
\text { cozido } \\
\end{array}$ & $\begin{array}{c}\text { quadrúpede } \\
\text { ave } \\
\text { quadrúpede } \\
\end{array}$ & $\begin{array}{c}\text { leitão } \\
\text { ave doméstica } \\
\text { vitela } \\
\end{array}$ & $\begin{array}{l}\text { VAL } \\
\text { VAL }\end{array}$ & $\begin{array}{l}\mathrm{BN} \\
\mathrm{BN}\end{array}$ & $\begin{array}{l}\text { MAZ } \\
\text { MAZ }\end{array}$ & $\begin{array}{l}\text { VAT } \\
\text { VAT }\end{array}$ \\
\hline Delicado & Entremezes & cozido & ave & & VAL & $\mathrm{BN}$ & & VAT \\
\hline Aves recheadas & Entremezes & assado & $\begin{array}{c}\text { ave } \\
\text { quadrúpede }\end{array}$ & $\begin{array}{c}\text { galinha } \\
\text { carneiro } \\
\text { vitela } \\
\end{array}$ & VAL & $\mathrm{BN}$ & MAZ & VAT \\
\hline Sem nome & Entremezes & cozido & ave & galinha & & $\mathrm{BN}$ & MAZ & \\
\hline Geléia de peixe ou carne & Entremezes & cozido & quadrúpede & & VAL & $\mathrm{BN}$ & MAZ & VAT \\
\hline Cisne revestido & Entremezes & assado & ave & cisne & VAL & $\mathrm{BN}$ & & VAT \\
\hline Sálvia fria & Entremezes & cozido & ave & & VAL & $\mathrm{BN}$ & MAZ & VAT \\
\hline Ensopado de leitão & Entremezes & cozido & quadrúpede & leitão & VAL & $\mathrm{BN}$ & MAZ & VAT \\
\hline Caldo de frango & Pratos $\mathrm{p} /$ doentes & cozido & ave & frango & $\mathrm{VAL}$ & $\mathrm{BN}$ & MAZ & VAT \\
\hline $\begin{array}{l}\text { Água rosada de capão } \\
\text { ou frango }\end{array}$ & Pratos $\mathrm{p} /$ doentes & cozido & ave & $\begin{array}{l}\text { capão } \\
\text { frango }\end{array}$ & VAL & $\mathrm{BN}$ & MAZ & VAT \\
\hline Manjar branco de capão & Pratos $\mathrm{p} /$ doentes & cozido & ave & capão & VAL & $\mathrm{BN}$ & MAZ & VAT \\
\hline Cuminade de peixe & Pratos $\mathrm{p} /$ doentes & cozido & ave & & & & & VAT \\
\hline Outras sopas menores & $\begin{array}{c}\text { Conhecimento } \\
\text { Geral }\end{array}$ & $\begin{array}{l}\text { cozido } \\
\text { cozido }\end{array}$ & $\begin{array}{l}\text { quadrúpede } \\
\text { quadrúpede }\end{array}$ & $\begin{array}{l}\text { vitela } \\
\text { porco }\end{array}$ & & & & VAT \\
\hline
\end{tabular}

Dos vários processos de cozimento, assar é o que mais fornece calor a uma carne e a seca ao máximo: este processo é mais apropriado para uma carne fria e úmida, como porco. A carne bovina, relativamente quente e seca, idealmente não deveria ser assada, 
mas cozida. Enquanto o cozimento confere um alto grau de umidade a uma carne, não a aquece tanto quanto assá-la. O cozimento foi o tratamento usual dado à carne de vaca pelos cozinheiros que usavam o Viandier. Era comum o processo de escaldar a carne em água fervente (blanchieren) antes de assá-la, para que, além de mais limpa, se tornasse mais consistente. A fritura, um processo intermediário, em seus efeitos, entre assar e cozinhar em água, esquenta moderadamente e, por causa do óleo ou gordura usados na panela, empresta uma moderada quantia de umidade à carne: a ave tem uma carne cujas propriedades relativamente seca e fria tornam sua fritura adequada em sua preparação. A fritura era usada muitas vezes como uma técnica adicional ao preparo, antes que a carne fosse assada. 


\subsubsection{A prática culinária e os grupos sociais}

No século XIII, aparecem os primeiros livros de culinária conhecidos desde o manual de Apicius, o que aponta o interesse renovado na preparação da comida. Tais receituários eram voltados para os profissionais de cozinha, cozinheiros a serviço dos ricos ou administradores de tabernas, como atesta a falta de indicações quantitativas. $\mathrm{O}$ público potencial, pelo menos nas cidades, era mais amplo. Mesmo assim, tratavam-se de pratos complexos e elaborados, de ingredientes caros, que certamente não configuravam a cozinha do dia-a-dia, e muito menos uma cozinha popular.

Os preceitos que definiam a natureza nobre ou vulgar de um alimento se baseavam num conjunto de teorias que eram consideradas objetivas. A dietética baseava-se no já mencionado princípio hierárquico vertical denominado grande cadeia do ser, na qual cada elemento tinha seu lugar. Uma pessoa não deveria consumir alimentos que ocupavam lugar elevado na cadeia do ser se sua posição social também não correspondesse a um lugar elevado. Da mesma forma, não deveria consumir alimentos inferiores se não fosse de grupo social inferior. Acreditava-se que desobedecer a esses preceitos traria riscos sérios para a saúde ${ }^{222}$. Essa ideologia alimentar, precisamente codificada entre os séculos XIV e XV, um período de considerável mobilidade social, reforçou uma tendência das classes dominantes a radicalizarem a afirmação dos privilégios ${ }^{223}$.

A terra era o elemento mais baixo e vil e a ela pertenciam as plantas, obedecendo a uma ordem hierárquica que ia dos bulbos às árvores frutíferas (quanto mais alta e longe do solo, melhor do que as outras). O segundo elemento estava associado à água, seguindo a ordem ascendente das esponjas aos golfinhos (que nadam na superfície). $\mathrm{O}$ terceiro era o ar, que agrupava os pássaros: dos aquáticos (patos e gansos) aos que voam em grandes altitudes (águias e falcões). O grupo do fogo só comportava animais mitológicos. Já os quadrúpedes não pareciam se ligar a qualquer elemento, ficavam acima dos vegetais e abaixo das aves. Sua carne era classificada de acordo com a mesma hierarquia, na qual a mais alta era a de vitelo, seguida pela de

\footnotetext{
${ }^{222}$ GRIECO, Allen F. Alimentação e classes sociais no fim da Idade Média e na Renascença. In: FLANDRIN, Jean Louis; MONTANARI, Massimo. (Org.). História da alimentação. Tradução Luciano Vieira Machado; Guilherme J. F. Teixeira. São Paulo: Estação Liberdade, 1998, p. 466-477.

223 MONTANARI, Massimo. Alimentação. Tradução Vivian Coutinho de Almeida. In: LE GOFF, Jacques; SCHMITT, Jean-Claude. (Org.). Dicionário temático do Ocidente Medieval. São Paulo: Edusc, v. 1, 2006, p. 35-45.
} 
carneiro (cardápio das classes mercadoras). O porco era o mais baixo da lista, particularmente desprezado quando conservado no sal, porque era a carne mais acessível às classes inferiores. As aves eram consideradas adequadas à alimentação das classes superiores, enquanto a pesada e rica carne de quadrúpedes era recomendada aos mercadores, cujo tipo de ofício exigia alimentação substancial. As classes inferiores deveriam comer porco ou animais mais velhos, em pouca quantidade, pois o ideal era que se alimentassem de grande quantidade de legumes ${ }^{224}$.

As iguarias senhoriais compreendiam todo tipo de caça e peixes, além dos animais de criação. Entre as carnes mais frequentes estão as carnes bovina, principalmente de vitela, e suína, assadas em espeto, ovelha e cabra, galinha, frango capão, cegonhas, pavões e cisnes ${ }^{225}$. O consumo de capões e perdizes, destinados pelos dietistas às classe superiores, incomodava sumptuários e moralistas ${ }^{226}$. Os médicos recomendavam também o consumo de animais jovens aos nobres e ociosos ${ }^{227}$.

A partir das contas do talho em Carpentras, parece possível supor que o consumo do carneiro era maior no verão. Nas demais estações o consumo tornava-se melhor distribuído, embora o cordeiro pareça predominar na primavera, coincidindo com a Páscoa, e a vaca no final do inverno. O consumo de vitela era mais raro, mas ocorria principalmente no verão, mais precisamente em agosto ${ }^{228}$.

Mestre Chuiquart nos fornece, em 1420, um inventário de apetrechos de uma cozinha principesca. Embora se trate de um documento do século $\mathrm{XV}$, podemos observar que tais utensílios eram provavelmente necessários ao preparo das iguarias apresentadas no Viandier, conforme segue abaixo:

\section{Utensílios para cozer:}

Grandes caldeirões para cozer as grandes carnes, e em barba ${ }^{229}$, médios para fazer paneladas e fazer outras coisas normais de cozinha.

Grandes sertãs penduráveis para coser os peixes.

\footnotetext{
224 Repetimos aqui, com mais detalhes, os preceitos da "grande cadeia do ser", apresentados resumidamente no item 1.2.1 A importância social, conforme GRIECO, Allen F. Alimentação e classes sociais no fim da Idade Média e na Renascença.

225 TREFZER, Rudolf. Clássicos da literatura culinária: os mais importantes livros da história da gastronomia. Tradução Marcelo Rondinelli. São Paulo: Senac, 2009, p. 26.

${ }_{226}$ GRIECO, Allen J. Food for thougth and food for the table. Polity Press, 1989, p. 59-92.

${ }^{227}$ LAURIOUX, Bruno. A Idade Média à mesa. Tradução Elsa Andringa. Sintra: Publicações EuropaAmérica, 1989, p. 58.

${ }^{228}$ STOUFF, Louis. Ravitaillement et alimentation em Provence aux XIV e XVe siècles. Paris: Mouton, 1970, p. 184-190.

${ }^{229} \mathrm{Em}$ grande quantidade.
} 
Selhas de barro em grande abundância, grandes e pequenas, para fazer paneladas.

Uma vintena de grandes caldeiras de ferro pra frigir.

20 assadores com espeto giratório, com espetos em madeira para carne, 120 espetos de ferro, 3 dúzias de lanças para assar as peças pequenas e 40 espetos pequenos para douraduras e espetos de assar carne.

Recipientes, utensílios de preparação:

Uma dúzia de grandes tinas, aproximadamente cinquenta gamelas menores, 60 retortas de duas asas, 100 selhas.

Uma dúzia de grandes almofarizes

6 grandes raspadores

100 colheres de madeira, 25 conchas com furos ${ }^{230}$

Um mesmo indivíduo poderia estar inserido em mais de um grupo, por exemplo, padres, cavaleiros, doentes, crianças e peregrinos, grupos aos quais correspondia um regime alimentar específico ${ }^{231}$. Na dieta das crianças filhas de reis e príncipes, o peixe era um alimento quase ausente, por ser frio e húmido e reforçar por isso a "impassibilidade" da criança. O mais frequente era o consumo de criação, principalmente de caldos de capões, pouco gordos, semelhantes aos oferecidos aos doentes $^{232}$.

Os camponeses cozinhavam a carne em água fervente, utilizando o máximo dos sucos nutritivos diluídos no caldo e, mesmo quando não eram mal alimentados, eram quase sempre mal nutridos. A iconografia desse período está repleta de aleijados e coxos. Uma explicação para tais ocorrências, tão frequentes, poderia ser a carência de vitamina D (presente nas gorduras animais), responsável pelo raquitismo e más formações congênitas. E vale observar, também, que à prática desse grupo talvez não fossem aplicáveis as regras dietéticas. Apenas aquele que podia comer muito, e de tudo, é que podia também se dar ao luxo de refletir sobre o que comer ou se comer pouco faria bem ou não. Tais discussões e sistemas de valores só fazem sentido, evidentemente, nos meios que os viram nascer: a aristocracia e a alta burguesia. Nos

\footnotetext{
${ }^{230}$ CHIQUART. Fait de cuisine. In: SCULLY, Terence. Du fait de cuisine par Maistre Chiquart, 1420. Vallesia, 1985, p. 133-134.

${ }^{231}$ LAURIOUX, Bruno. A Idade Média à mesa. Tradução Elsa Andringa. Sintra: Publicações EuropaAmérica, 1989, p. 31.

${ }^{232}$ CONTAMINE, Philippe. La vie quotidienne pendantla guerre de Cent Ans. Paris: Hachette, 1976, p. 166.
} 
meios populares, operários e camponeses, a colocação de temas e opções não fazia o menor sentido. Os esfomeados desejavam sempre se empanturrar. E se o fazem raramente, sonham com freqüência. Temer um apetite refreado é privilégio de quem vive na abundância.

Os miúdos dos animais eram, muitas vezes, relegados ao consumo popular, por serem considerados pouco nobres. Fígado, moela, coração, língua, baço, tripas e testículos do porco, carneiro e bezerro, eram mais baratos e utilizados na alimentação da criadagem. Era comum que as carnes mais ordinárias das cozinhas chegassem ao comércio de rua e, daí, à ementa de burgueses ou pobres. As cozinhas inglesas previam uma partilha desses bocados entre os mestres-cozinheiros e o dono do animal, e um decreto inglês de 1379 proibiu os pasteleiros de obterem com os cozinheiros das casas senhoriais intestinos de galinhas, capões e patos, para evitar a venda de empadas estragadas $^{233}$.

$\mathrm{Na}$ casa camponesa encontrava-se a lareira, quase sempre no nível do chão, servindo de fonte de luz e calor, além de preparar o alimento. Algumas vezes havia um buraco no teto, o que deixava passar vento e chuva, mas o mais comum era que o fumo saísse pela porta, janela ou fissuras na parede e no teto. Os principais equipamentos de cozinha eram a caldeira de metal, potes e panelas de argila e a sertã de ferro ou estanho. Esses equipamentos possibilitavam a fervura, a cozedura lenta, a estufagem e a fritura; mas grelhados e assados necessitariam de grelha e espeto, que só eram mais comuns nos meios urbanos e entre as elites, o que demonstra ser o assado um sinal de prestígio social $^{234}$.

\footnotetext{
${ }^{233}$ LAURIOUX, Bruno. A Idade Média à mesa. Tradução Elsa Andringa. Sintra: Publicações EuropaAmérica, 1989, p. 30.

${ }^{234}$ Ibidem, p. 72.
} 


\subsubsection{O equilíbrio necessário}

O esforço de temperar mediante o uso de ingredientes que se compensam e se equilibram, manteve-se mesmo diante da doutrina elitista ${ }^{235}$. Os pratos condimentados eram acompanhados de purês de legumes ou favas e a maioria das receitas continha ingredientes azedos ${ }^{236}$.

O Viandier não ilustra em todos os detalhes as recomendações que Magninus fez em seu capítulo De saporibus et condimentis, quanto à maneira que a carne poderia ser preparada ou os mais adequados molhos a serem usados. Gostos singulares e tradições gastronômicas peculiares, para não mencionar considerações de ordem econômica, influenciavam o cozinheiro de cada casa. O que aparece usualmente no Viandier é uma culinária prática que reconhece, de um modo geral, as doutrinas propagadas pelas escolas de medicina contemporâneas, no que se refere aos mais saudáveis meios de cozinhar e preparar carnes especiais e os mais salubres condimentos a serem consumidos com elas.

A seguir, apresentamos duas tabelas que ilustram o uso de molhos nas receitas do Viandier anteriores ao século XV. A primeira tabela refere-se às receitas que utilizam carne e nas quais consta uma referência específica ao molho que deve ser servido como acompanhamento da iguaria.

Tabela 10 - Receitas de carne com especificação de molho no Viandier

\begin{tabular}{|c|c|c|c|c|c|c|c|c|}
\hline RECEITA & $\begin{array}{l}\text { MODO DE } \\
\text { PREPARO }\end{array}$ & $\begin{array}{l}\text { TIPO DE } \\
\text { CARNE }\end{array}$ & ESPÉCIE & $\begin{array}{c}\text { MOLHO } \\
\text { RECOMENDADO }\end{array}$ & \multicolumn{4}{|c|}{$\begin{array}{c}\text { CONSTANTE NOS } \\
\text { MANUSCRITOS }\end{array}$} \\
\hline $\begin{array}{l}\text { Fervura de } \\
\text { carne gorda }\end{array}$ & cozido & quadrúpede & $\begin{array}{c}\text { vaca } \\
\text { porco } \\
\text { carneiro } \\
\end{array}$ & $\begin{array}{c}\text { alho branco } \\
\text { alho verde } \\
\text { verde } \\
\text { verde } \\
\end{array}$ & & $\mathrm{BN}$ & MAZ & VAT \\
\hline $\begin{array}{l}\text { Veadada de veado } \\
\text { Fresco }\end{array}$ & $\begin{array}{l}\text { cozido } \\
\text { empada }\end{array}$ & quadrúpede & veado & $\begin{array}{l}\text { camelino } \\
\text { camelino } \\
\end{array}$ & VAL & & MAZ & VAT \\
\hline Javali & $\begin{array}{l}\text { cozido } \\
\text { cozido }\end{array}$ & $\begin{array}{l}\text { quadrúpede } \\
\text { quadrúpede }\end{array}$ & $\begin{array}{l}\text { javali } \\
\text { veado }\end{array}$ & $\begin{array}{c}\text { camelino } \\
\text { de pimenta forte } \\
\text { de mostarda } \\
\text { camelino } \\
\text { de pimenta forte } \\
\text { de mostarda }\end{array}$ & VAL & $\mathrm{BN}$ & MAZ & VAT \\
\hline
\end{tabular}

${ }^{235}$ SCULLY, Terence. The art of cookery in the Middle Age. Woodbridge: The Boydell Press, 1995, p. 41-53.

${ }^{236}$ Setenta por cento das receitas do Viandier apresentam ingredientes azedos. 


\begin{tabular}{|c|c|c|c|c|c|c|c|c|}
\hline Cabra selvagem & $\begin{array}{l}\text { cozido } \\
\text { empada }\end{array}$ & quadrúpede & cabra & $\begin{array}{l}\text { camelino } \\
\text { camelino }\end{array}$ & VAL & $\mathrm{BN}$ & MAZ & \\
\hline Caldo georgié & cozido & ave & doméstica & de mostarda & VAL & $\mathrm{BN}$ & MAZ & VAT \\
\hline Vitela assada & $\begin{array}{l}\text { assado } \\
\text { empada } \\
\end{array}$ & $\begin{array}{l}\text { quadrúpede } \\
\text { quadrúpede }\end{array}$ & $\begin{array}{c}\text { vitela } \\
\text { vitela } \\
\end{array}$ & camelino & & $\mathrm{BN}$ & MAZ & VAT \\
\hline Carneiro assado & assado & quadrúpede & carneiro & camelino & VAL & $\mathrm{BN}$ & MAZ & VAT \\
\hline $\begin{array}{l}\text { Cabras novas, } \\
\text { Cordeiros }\end{array}$ & assado & $\begin{array}{l}\text { quadrúpede } \\
\text { quadrúpede }\end{array}$ & $\begin{array}{c}\text { cordeiro } \\
\text { cabra }\end{array}$ & $\begin{array}{l}\text { camelino } \\
\text { camelino }\end{array}$ & VAL & $\mathrm{BN}$ & MAZ & VAT \\
\hline Gansos & assado & ave & ganso & $\begin{array}{c}\text { de alho branco } \\
\text { de pimenta preta } \\
\text { de alho verde } \\
\text { jance } \\
\text { saintmerry } \\
\end{array}$ & VAL & $\mathrm{BN}$ & MAZ & VAT \\
\hline Galinhas assadas & $\begin{array}{l}\text { assado } \\
\text { empada }\end{array}$ & $\begin{array}{l}\text { ave } \\
\text { ave }\end{array}$ & $\begin{array}{l}\text { galinha } \\
\text { galinha }\end{array}$ & $\begin{array}{c}\text { camelino } \\
\text { de sálvia frio }\end{array}$ & VAL & $\mathrm{BN}$ & MAZ & VAT \\
\hline $\begin{array}{l}\text { Capões, galinhas } \\
\text { e galos }\end{array}$ & assado & ave & $\begin{array}{l}\text { capão } \\
\text { galinha } \\
\text { galo }\end{array}$ & $\begin{array}{c}\text { must } \\
\text { poitevin } \\
\text { jance }\end{array}$ & VAL & $\mathrm{BN}$ & MAZ & VAT \\
\hline Coelhos assados & $\begin{array}{l}\text { assado } \\
\text { empada }\end{array}$ & $\begin{array}{l}\text { quadrúpede } \\
\text { quadrúpede }\end{array}$ & $\begin{array}{l}\text { coelho } \\
\text { coelho }\end{array}$ & $\begin{array}{l}\text { camelino } \\
\text { camelino }\end{array}$ & VAL & $\mathrm{BN}$ & MAZ & VAT \\
\hline Capões gordurosos & assado & ave & capão & dodine & & & & VAT \\
\hline Lebres assadas & $\begin{array}{l}\text { assado } \\
\text { empada }\end{array}$ & $\begin{array}{l}\text { quadrúpede } \\
\text { quadrúpede }\end{array}$ & $\begin{array}{l}\text { lebre } \\
\text { lebre }\end{array}$ & $\begin{array}{l}\text { camelino } \\
\text { saupicket } \\
\text { camelino }\end{array}$ & VAL & $\mathrm{BN}$ & MAZ & VAT \\
\hline Veados frescos & assado & quadrúpede & veado & camelino & & $\mathrm{BN}$ & MAZ & VAT \\
\hline $\begin{array}{l}\text { Carambolas } \\
\text { e galinholas }\end{array}$ & $\begin{array}{l}\text { assado } \\
\text { empada }\end{array}$ & $\begin{array}{l}\text { ave } \\
\text { ave }\end{array}$ & $\begin{array}{c}\text { carambola } \\
\text { galinhola } \\
\text { carambola } \\
\text { galinhola }\end{array}$ & camelino & & $\mathrm{BN}$ & & VAT \\
\hline Cisnes & assado & ave & cisne & de pimenta amarela & $\mathrm{VAL}$ & $\mathrm{BN}$ & MAZ & VAT \\
\hline Garças-reais & assado & ave & garça & camelino & $\mathrm{VAL}$ & $\mathrm{BN}$ & MAZ & VAT \\
\hline Pato-real do rio & assado & ave & pato do rio & dodine & VAL & $\mathrm{BN}$ & MAZ & VAT \\
\hline Colhereiros & assado & ave & colheiro & camelino & & & & VAT \\
\hline Marrequinho & assado & ave & marrequinho & dodine & & & & VAT \\
\hline Leitão recheado & assado & quadrúpede & leitão & $\begin{array}{c}\text { de pimenta amarela } \\
\text { camelino } \\
\end{array}$ & VAL & $\mathrm{BN}$ & MAZ & VAT \\
\hline Cisne revestido & assado & ave & cisne & de pimenta amarela & VAL & $\mathrm{BN}$ & & VAT \\
\hline
\end{tabular}

Molhos demandam o uso de um líquido base (água ou caldo, vinho, vinagre ou suco), no qual se faz a infusão de especiarias e ervas com a ocasional adição de agentes saborosos ou coloríficos. Ao contrário dos molhos de Apicius, na cozinha romana, os molhos medievais não utilizavam gordura ${ }^{237}$ e nem espessamento por meio de farinha. Eram engrossados com miolo de pão, amêndoas, nozes ou gema de ovo. Seu elemento principal era o agraço.

\footnotetext{
${ }^{237}$ Os molhos medievais não continham óleo ou manteiga.
} 
O camelino é um molho de canela e vinagre cujos ingredientes tornam-no moderadamente quente e muito seco: é apropriado para usar com carnes bem temperadas, como a de veado quando cozida, pois a carne de veado é, por sua natureza, seca, ou vitela, quando assada, pois é uma carne relativamente úmida. Similarmente, amêndoas são frequentemente usadas em molhos, inclusive com os mais suaves, sendo moderadamente quentes e úmidas. Peixes frios e úmidos, como enguia, requerem um tratamento especial de calor e secura oferecidos pelo Molho Verde, cujo principal ingrediente, a salsa, é considerado muito quente e muito seco.

A segunda tabela, complementar à primeira, refere-se às receitas de molhos (anteriores ao século XV) constantes no Viandier, com destaque para seus elementos ácidos e especiarias mais frequentemente utilizados.

Tabela 11 - Receitas de molho no Viandier

\begin{tabular}{|c|c|c|c|c|c|c|c|c|}
\hline RECEITA & $\begin{array}{l}\text { MODO DE } \\
\text { PREPARO } \\
\end{array}$ & $\begin{array}{c}\text { ESPÉCIE } \\
\text { UTILIZADA }\end{array}$ & $\begin{array}{c}\text { INGREDIENTE } \\
\text { ÁCIDO } \\
\end{array}$ & ESPECIARIAS & \multicolumn{4}{|c|}{$\begin{array}{c}\text { CONSTANTE NOS } \\
\text { MANUSCRITOS } \\
\end{array}$} \\
\hline Camelino & & & vinagre & $\begin{array}{c}\text { Canela } \\
\text { Cravo } \\
\text { gengibre } \\
\text { grãos do paraíso } \\
\text { Macis } \\
\text { pimenta longa } \\
\end{array}$ & VAL & $\mathrm{BN}$ & MAZ & VAT \\
\hline Camelino de alho & & arraia & $\begin{array}{l}\text { agraço } \\
\text { vinagre }\end{array}$ & Canela & VAL & $\mathrm{BN}$ & MAZ & VAT \\
\hline Alho branco & & & agraço & & & $\mathrm{BN}$ & & VAT \\
\hline Alho verde & & & agraço & & VAL & $\mathrm{BN}$ & MAZ & VAT \\
\hline Alho e arenque fresco & & arenque & agraço & & VAL & $\mathrm{BN}$ & MAZ & VAT \\
\hline $\begin{array}{l}\text { Sem nome: Molho de alho } \\
\text { e amêndoas }\end{array}$ & & & agraço & & & & MAZ & \\
\hline Molho verde & & & $\begin{array}{l}\text { agraço } \\
\text { vinagre } \\
\end{array}$ & gengibre & VAL & BN & MAZ & VAT \\
\hline $\begin{array}{l}\text { Molho para guardar } \\
\text { o peixe }\end{array}$ & & & $\begin{array}{l}\text { agraço } \\
\text { vinagre }\end{array}$ & $\begin{array}{c}\text { açafrão } \\
\text { Canela } \\
\text { Cássia } \\
\text { gengibre } \\
\text { grãos do paraíso } \\
\text { noz-moscada } \\
\text { pimenta longa }\end{array}$ & VAL & $\mathrm{BN}$ & MAZ & VAT \\
\hline Barba do Roberto & fervido & & & & & & & VAT \\
\hline Pimenta amarela & fervido & & $\begin{array}{l}\text { agraço } \\
\text { vinagre }\end{array}$ & $\begin{array}{c}\text { açafrão } \\
\text { Cravo } \\
\text { pimenta longa } \\
\text { gengibre } \\
\end{array}$ & VAL & $\mathrm{BN}$ & MAZ & VAT \\
\hline Pimenta Negra & fervido & & $\begin{array}{c}\text { agraço } \\
\text { vinagre }\end{array}$ & $\begin{array}{c}\text { gengibre } \\
\text { pimenta redonda } \\
\end{array}$ & VAL & BN & MAZ & \\
\hline Molho jance de leite de vaca & fervido & & & gengibre & VAL & $\mathrm{BN}$ & MAZ & \\
\hline Molho jance ao alho & fervido & & agraço & gengibre & VAL & $\mathrm{BN}$ & MAZ & \\
\hline
\end{tabular}




\begin{tabular}{|l|l|l|l|l|l|l|l|l|} 
Jance de gengibre & fervido & & agraço & gengibre & & BN & & \\
\hline Um poitevine & fervido & frango & agraço & $\begin{array}{c}\text { Cravo } \\
\text { gengibre } \\
\text { grãos do paraíso }\end{array}$ & VAL & BN & MAZ & \\
\hline
\end{tabular}

Numa casa nobre do final da Idade Média, especiarias não eram meramente propriedades do domínio culinário ou gastronômico. Elas estavam sob o domínio do curandeiro da corte, que receitava especiarias do mesmo modo que receitava remédios, e pelas mesmas razões. Especiarias eram variedades de remédios que alteravam e agiam sobre o estado de humor e temperamento da pessoa ou alimentos aos quais eram $\operatorname{aplicados}^{238}$. Na tradição hipocrático-galênica, especiarias eram geralmente elementos de natureza seca (gengibre é uma exceção) e quente, variando nesses aspectos meramente entre alto (canela e cravo) e extremo (mostarda e pimenta).

Desse modo, as especiarias valorizadas eram as "altas especiarias": o cravo, a noz-moscada e os grãos do paraíso ${ }^{239}$. A pimenta já era considerada especiaria popular, condimento de pobre, e consistia em setenta e cinco por cento das especiarias importadas por Veneza. Mas se os cozinheiros da França renunciaram à pimenta, os livros de cozinha inglesa ainda continuaram a utilizá-la numa medida de nove a trinta e dois por cento de suas receitas 240 .

Em 1256, Aldebrandino de Siena, em $O$ Regime do Corpo, lista as qualidades medicinais dos grãos do paraíso, ou cardamomo:

O cardamomo é quente e seco ao terceiro grau, e fiquem sabendo que é fruto de uma árvore que, na primavera, deita botões parecidos com a semente de arruda, dentro das quais está o cardamomo. Há duas espécies, o grande e o pequeno; o grande é o melhor, pois tem um aroma mais atrativo. O cardamomo deve ter um sabor agridoce. Quando se quer comê-lo, é preciso separá-lo do cascalho com que está misturado e esfrega-lo num pano, para lhe retirar a poeira. E esse mesmo cardamomo pode conservar-se durante dez anos. O cardamomo tem como qualidades fortalecer o corpo, eliminar os gases e os grandes e maus humores que enfraquecem o estômago. Faz com que a carne coza mais depressa e melhor. Juntem cardamomo, e anis, reduzam-nos a pó, e utilizem esse pó para abrir o apetite. Para acabar com os vômitos, agarrem esse cardamomo em pó, hortelã e salsa e façam um molho com vinagre: esse molho restabelece o apetite. Cheirar pura e simplesmente o cardamomo, faz bem aos fracos de estômago (Aldebrandino de Siena, 1911 apud LAURIOUX, 1989, p. 142) ${ }^{241}$.

\footnotetext{
${ }^{238}$ SCULLY, Terence. The Viandier of Taillevent. Ottawa: University of Ottawa Press, 1988, passim.

239 Amomum Melegueta também é conhecida como cardamomo ou grão-da-guiné.

${ }^{240}$ LAURIOUX, Bruno. A Idade Média à mesa. Tradução Elsa Andringa. Sintra: Publicações EuropaAmérica, 1989, p. 37-41.

${ }^{241}$ ALDEBRANDINO DE SIENA. O regime do corpo. Edição L. Landouzy; R. Pépin. Paris, 1911.
} 
Bartolomeu, o inglês, no Livro das Propriedades das Coisas, mencionou que a canela era encontrada na China, no ninho da ave fênix fêmea e que a ave não poderia ser apanhada, a não ser que ela caísse de tal ninho devido ao peso ou se fosse abatida com flecha de chumbo. E que a pimenta crescia no Cáucaso, em local vigiado por serpentes, que são afugentadas com fogo e, por isso, a pimenta era torrada e tornava-se negra ${ }^{242}$.

Das quinze receitas de molho apresentadas no Viandier (anteriores ao século $\mathrm{XV}$ ), nove levam gengibre em seu preparo. O cravo, a canela (e/ou cássia), os grãos do paraíso e a pimenta longa (similar à pimenta negra, só que mais picante) aparecem mencionados em três receitas de molho cada um. O açafrão é mencionado em duas receitas, assim como a noz-moscada (e/ou macis).

Segue uma tabela ilustrativa das especiarias mais frequentemente mencionadas no Viandier, nas receitas anteriores ao século XV. Em algumas dessas receitas não era recomendado, especificamente, o uso de determinado molho, mas em outras sim, além das já contidas especiarias, como se pode notar numa comparação com as tabelas anteriores. Também nas quarenta e cinco receitas do Viandier, anteriores ao século XV, que utilizam carne e mencionam especiarias, mas não consistem em receitas de molhos, o gengibre é a mais utilizada, sendo um ingrediente mencionado em vinte e oito delas. O açafrão é mencionado em vinte e quatro dessas receitas, a canela (e/ou cássia) é mencionada em dezessete ${ }^{243}$, o cravo em dezesseis, os grãos do paraíso também em dezesseis, a noz-moscada (e/ou macis) em $\operatorname{seis}^{244}$. A pimenta, por sua vez, é mencionada em cinco dessas receitas, sendo que em quatro delas trata-se da pimenta longa. E por treze vezes essas receitas mencionam simplesmente o uso de "especiarias em pó".

Tabela 12 - Especiarias mais frequentes no Viandier

\begin{tabular}{|c|c|c|c|c|c|c|c|c|}
\hline RECEITA & $\begin{array}{c}\text { MODO } \\
\text { DE } \\
\text { PREPARO } \\
\end{array}$ & $\begin{array}{l}\text { TIPO DE } \\
\text { CARNE }\end{array}$ & ESPÉCIE & $\begin{array}{c}\text { ESPECIARIAS } \\
\text { MENCIONADAS }\end{array}$ & \multicolumn{4}{|c|}{$\begin{array}{c}\text { CONSTANTE NOS } \\
\text { MANUSCRITOS }\end{array}$} \\
\hline Retalhado de carneiro & cozido & quadrúpede & carneiro & $\begin{array}{c}\text { açafrão } \\
\text { especiarias diversas } \\
\text { macis } \\
\end{array}$ & & $\mathrm{BN}$ & MAZ & VAT \\
\hline Carnes entremeadas & cozido & quadrúpede & & $\begin{array}{l}\text { açafrão } \\
\text { macis }\end{array}$ & VAL & $\mathrm{BN}$ & MAZ & VAT \\
\hline Veadada de veado fresco & cozido & quadrúpede & veado & especiarias diversas & VAL & & MAZ & VAT \\
\hline
\end{tabular}

\footnotetext{
${ }^{242}$ BARTOLOMEU. Livro das propriedades das coisas. Tradução francesa de Jean Corbechon. Biblioteca Nacional, manuscrito fr. 22532, fols. 246 e 267. In: LAURIOUX, Bruno. A Idade Média à mesa. Trad. Elsa Andringa. Sintra: Publicações Europa-América, 1989, p. 143.

${ }^{243}$ A cássia aparece três vezes e sempre em receitas que utilizam também a canela.

${ }^{244}$ A noz-moscada é mencionada em três dessas receitas, sendo que em uma delas o macis também é utilizado.
} 


\begin{tabular}{|c|c|c|c|c|c|c|c|c|}
\hline & empada & & & macis & & & & \\
\hline Cabra selvagem & $\begin{array}{l}\text { cozido } \\
\text { empada }\end{array}$ & quadrúpede & cabra & $\begin{array}{c}\text { especiarias diversas } \\
\text { macis } \\
\end{array}$ & VAL & $\mathrm{BN}$ & MAZ & \\
\hline Capões ou vitela com ervas & $\begin{array}{l}\text { cozido } \\
\text { cozido }\end{array}$ & $\begin{array}{c}\text { ave } \\
\text { quadrúpede }\end{array}$ & $\begin{array}{l}\text { capão } \\
\text { vitela }\end{array}$ & $\begin{array}{l}\text { açafrão } \\
\text { gengibre } \\
\text { açafrão } \\
\text { gengibre }\end{array}$ & & $\mathrm{BN}$ & & VAT \\
\hline Caldo quente de porco & cozido & quadrúpede & porco & $\begin{array}{c}\text { açafrão } \\
\text { gengibre } \\
\text { pimenta longa }\end{array}$ & VAL & $\mathrm{BN}$ & MAZ & VAT \\
\hline Cretonada de ervilhas & cozido & ave & galinha & $\begin{array}{c}\text { açafrão } \\
\text { gengibre }\end{array}$ & VAL & $\mathrm{BN}$ & MAZ & VAT \\
\hline Cretonada de favas & cozido & ave & galinha & $\begin{array}{c}\text { açafrão } \\
\text { gengibre }\end{array}$ & & $\mathrm{BN}$ & MAZ & VAT \\
\hline Cuminade de aves & cozido & ave & & $\begin{array}{l}\text { cominho } \\
\text { gengibre }\end{array}$ & VAL & $\mathrm{BN}$ & MAZ & VAT \\
\hline Cuminade de amêndoas & cozido & ave & & $\begin{array}{l}\text { cominho } \\
\text { gengibre }\end{array}$ & VAL & $\mathrm{BN}$ & & VAT \\
\hline Caldo de canela & $\begin{array}{l}\text { cozido } \\
\text { cozido }\end{array}$ & $\begin{array}{c}\text { ave } \\
\text { quadrúpede }\end{array}$ & & $\begin{array}{c}\text { canela } \\
\text { cravo } \\
\text { grãos do paraíso } \\
\text { gengibre } \\
\text { canela } \\
\text { cravo } \\
\text { grãos do paraíso } \\
\text { gengibre } \\
\end{array}$ & VAL & $\mathrm{BN}$ & MAZ & VAT \\
\hline Caldo georgié & cozido & ave & doméstica & $\begin{array}{c}\text { açafrão } \\
\text { cravo } \\
\text { gengibre }\end{array}$ & VAL & $\mathrm{BN}$ & MAZ & VAT \\
\hline Caldo ruivo & $\begin{array}{l}\text { cozido } \\
\text { cozido }\end{array}$ & $\begin{array}{l}\text { quadrúpede } \\
\text { ave }\end{array}$ & & $\begin{array}{c}\text { canela } \\
\text { cássia } \\
\text { cravo } \\
\text { gengibre } \\
\text { grãos do paraíso } \\
\text { canela } \\
\text { cássia } \\
\text { cravo } \\
\text { gengibre } \\
\text { grãos do paraíso }\end{array}$ & VAL & $\mathrm{BN}$ & MAZ & VAT \\
\hline Vísceras de porco & cozido & quadrúpede & porco & $\begin{array}{c}\text { açafrão } \\
\text { gengibre } \\
\text { grãos do paraíso } \\
\end{array}$ & VAL & $\mathrm{BN}$ & MAZ & VAT \\
\hline Molho de pássaros & cozido & ave & & $\begin{array}{c}\text { canela } \\
\text { gengibre }\end{array}$ & VAL & $\mathrm{BN}$ & MAZ & VAT \\
\hline Caldo branco de capões & cozido & ave & capão & $\begin{array}{c}\text { canela } \\
\text { cravo } \\
\text { gengibre } \\
\text { grãos do paraíso } \\
\text { pimenta longa }\end{array}$ & VAL & $\mathrm{BN}$ & MAZ & VAT \\
\hline $\begin{array}{l}\text { Aferventado de lebres } \\
\text { ou coelhos }\end{array}$ & $\begin{array}{l}\text { cozido } \\
\text { cozido }\end{array}$ & $\begin{array}{l}\text { quadrúpede } \\
\text { quadrúpede }\end{array}$ & $\begin{array}{l}\text { lebre } \\
\text { coelho }\end{array}$ & $\begin{array}{c}\text { canela } \\
\text { cravo } \\
\text { grãos do paraíso } \\
\text { canela } \\
\text { cravo } \\
\text { grãos do paraíso }\end{array}$ & VAL & $\mathrm{BN}$ & MAZ & VAT \\
\hline
\end{tabular}




\begin{tabular}{|c|c|c|c|c|c|c|c|c|}
\hline Aferventado de capões & cozido & ave & capão & $\begin{array}{c}\text { canela } \\
\text { cravo } \\
\text { gengibre } \\
\text { grãos do paraíso }\end{array}$ & VAL & $\mathrm{BN}$ & MAZ & VAT \\
\hline $\begin{array}{l}\text { Caldo alemão de coelhos } \\
\text { ou aves }\end{array}$ & $\begin{array}{l}\text { cozido } \\
\text { cozido }\end{array}$ & $\begin{array}{c}\text { quadrúpede } \\
\text { ave }\end{array}$ & coelho & $\begin{array}{c}\text { açafrão } \\
\text { canela } \\
\text { cravo } \\
\text { gengibre } \\
\text { grãos do paraíso } \\
\text { noz-moscada } \\
\text { açafrão } \\
\text { canela } \\
\text { cravo } \\
\text { gengibre } \\
\text { grãos do paraíso } \\
\text { noz-moscada } \\
\end{array}$ & VAL & $\mathrm{BN}$ & MAZ & VAT \\
\hline Mexido de aves & cozido & ave & & $\begin{array}{c}\text { canela } \\
\text { gengibre } \\
\text { grãos do paraíso }\end{array}$ & VAL & $\mathrm{BN}$ & MAZ & VAT \\
\hline Rápido caldo inglês & cozido & quadrúpede & porco & $\begin{array}{c}\text { açafrão } \\
\text { canela } \\
\text { cravo } \\
\text { gengibre } \\
\text { pimenta longa } \\
\end{array}$ & VAL & $\mathrm{BN}$ & MAZ & VAT \\
\hline Caldo de agraço & $\begin{array}{l}\text { cozido } \\
\text { cozido }\end{array}$ & $\begin{array}{c}\text { quadrúpede } \\
\text { ave }\end{array}$ & & $\begin{array}{l}\text { gengibre } \\
\text { gengibre }\end{array}$ & VAL & $\mathrm{BN}$ & & VAT \\
\hline Caldo amarelo-verde & $\begin{array}{l}\text { cozido } \\
\text { cozido }\end{array}$ & $\begin{array}{c}\text { quadrúpede } \\
\text { ave }\end{array}$ & & $\begin{array}{c}\text { açafrão } \\
\text { gengibre } \\
\text { açafrão } \\
\text { gengibre }\end{array}$ & VAL & $\mathrm{BN}$ & MAZ & VAT \\
\hline Guisado de vitela & cozido & quadrúpede & vitela & $\begin{array}{c}\text { açafrão } \\
\text { canela } \\
\text { cravo } \\
\text { gengibre } \\
\text { grãos do paraíso }\end{array}$ & VAL & $\mathrm{BN}$ & MAZ & VAT \\
\hline Guisado de lebres & cozido & quadrúpede & lebre & $\begin{array}{c}\text { açafrão } \\
\text { canela } \\
\text { cravo } \\
\text { gengibre } \\
\text { grãos do paraíso }\end{array}$ & VAL & $\mathrm{BN}$ & MAZ & VAT \\
\hline Guisado de coelhos & cozido & quadrúpede & coelho & $\begin{array}{c}\text { açafrão } \\
\text { canela } \\
\text { cravo } \\
\text { gengibre } \\
\text { grãos do paraíso }\end{array}$ & & $\mathrm{BN}$ & & VAT \\
\hline Porco assado & $\begin{array}{l}\text { assado } \\
\text { empada }\end{array}$ & $\begin{array}{l}\text { quadrúpede } \\
\text { quadrúpede }\end{array}$ & $\begin{array}{l}\text { porco } \\
\text { porco }\end{array}$ & $\begin{array}{c}\text { açafrão } \\
\text { especiarias diversas }\end{array}$ & VAL & $\mathrm{BN}$ & MAZ & VAT \\
\hline Vitela assada & $\begin{array}{l}\text { assado } \\
\text { empada }\end{array}$ & $\begin{array}{l}\text { quadrúpede } \\
\text { quadrúpede }\end{array}$ & $\begin{array}{l}\text { vitela } \\
\text { porco }\end{array}$ & $\begin{array}{c}\text { açafrão } \\
\text { especiarias diversas }\end{array}$ & & $\mathrm{BN}$ & MAZ & VAT \\
\hline Desfiado de bezerro & frito & quadrúpede & bezerro & $\begin{array}{c}\text { açafrão } \\
\text { especiarias diversas } \\
\text { gengibre } \\
\end{array}$ & VAL & $\mathrm{BN}$ & MAZ & VAT \\
\hline Galinhas assadas & assado & ave & galinha & & VAL & $\mathrm{BN}$ & MAZ & VAT \\
\hline
\end{tabular}




\begin{tabular}{|c|c|c|c|c|c|c|c|c|}
\hline & empada & ave & galinha & especiarias diversas & & & & \\
\hline Coelhos assados & $\begin{array}{l}\text { assado } \\
\text { empada }\end{array}$ & $\begin{array}{l}\text { quadrúpede } \\
\text { quadrúpede }\end{array}$ & $\begin{array}{l}\text { coelho } \\
\text { coelho }\end{array}$ & especiarias diversas & VAL & $\mathrm{BN}$ & MAZ & VAT \\
\hline Lebres assadas & $\begin{array}{l}\text { assado } \\
\text { empada }\end{array}$ & $\begin{array}{l}\text { quadrúpede } \\
\text { quadrúpede }\end{array}$ & $\begin{array}{l}\text { lebre } \\
\text { lebre }\end{array}$ & especiarias diversas & VAL & $\mathrm{BN}$ & MAZ & VAT \\
\hline Atoleiro de javali fresco & assado & quadrúpede & javali & $\begin{array}{c}\text { canela } \\
\text { cravo } \\
\text { gengibre } \\
\text { grãos do paraíso }\end{array}$ & VAL & $\mathrm{BN}$ & MAZ & VAT \\
\hline Pato-real do rio & assado & ave & pato do rio & especiarias diversas & VAL & $\mathrm{BN}$ & MAZ & VAT \\
\hline Marrequinho & assado & ave & marrequinho & especiarias diversas & & & & VAT \\
\hline Leitão recheado & assado & quadrúpede & leitão & especiarias diversas & VAL & $\mathrm{BN}$ & MAZ & VAT \\
\hline Falso grenon & $\begin{array}{l}\text { cozido } \\
\text { cozido }\end{array}$ & ave & $\begin{array}{c}\text { ave } \\
\text { doméstica } \\
\text { vitela }\end{array}$ & $\begin{array}{c}\text { açafrão } \\
\text { canela } \\
\text { cravo } \\
\text { gengibre } \\
\text { grãos do paraíso } \\
\text { açafrão } \\
\text { canela } \\
\text { cravo } \\
\text { gengibre } \\
\text { grãos do paraíso }\end{array}$ & VAL & $\mathrm{BN}$ & MAZ & VAT \\
\hline Delicado & cozido & ave & & $\begin{array}{l}\text { açafrão } \\
\text { pimenta }\end{array}$ & VAL & $\mathrm{BN}$ & & VAT \\
\hline Aves recheadas & assado & $\begin{array}{c}\text { ave } \\
\text { quadrúpede }\end{array}$ & $\begin{array}{c}\text { galinha } \\
\text { carneiro } \\
\text { vitela }\end{array}$ & $\begin{array}{c}\text { açafrão } \\
\text { especiarias diversas }\end{array}$ & VAL & $\mathrm{BN}$ & MAZ & VAT \\
\hline Sem nome & cozido & ave & galinha & açafrão & & $\mathrm{BN}$ & MAZ & \\
\hline Geléia de peixe ou carne & cozido & quadrúpede & & $\begin{array}{c}\text { açafrão } \\
\text { canela } \\
\text { cássia } \\
\text { cravo } \\
\text { gengibre } \\
\text { macis } \\
\text { noz-moscada } \\
\text { pimenta longa }\end{array}$ & VAL & $\mathrm{BN}$ & MAZ & VAT \\
\hline Sálvia fria & cozido & ave & & $\begin{array}{c}\text { açafrão } \\
\text { canela } \\
\text { cássia } \\
\text { cravo } \\
\text { gengibre } \\
\text { grãos do paraíso }\end{array}$ & VAL & $\mathrm{BN}$ & MAZ & VAT \\
\hline Ensopado de leitão & cozido & quadrúpede & leitão & $\begin{array}{c}\text { canela } \\
\text { cravo } \\
\text { gengibre } \\
\text { grãos do paraíso } \\
\end{array}$ & VAL & $\mathrm{BN}$ & MAZ & VAT \\
\hline $\begin{array}{l}\text { Água rosada de capão } \\
\text { ou frango }\end{array}$ & cozido & ave & $\begin{array}{l}\text { capão } \\
\text { frango }\end{array}$ & $\begin{array}{l}\text { açafrão } \\
\text { açafrão }\end{array}$ & VAL & $\mathrm{BN}$ & MAZ & VAT \\
\hline Cuminade de peixe & cozido & ave & & $\begin{array}{l}\text { cominho } \\
\text { gengibre }\end{array}$ & & & & VAT \\
\hline
\end{tabular}


Le Ménagier de Paris apresenta sua receita de "especiarias em pó", utilizadas frequentemente nas receitas do Viandier, e apresentadas na tabela acima como especiarias diversas, uma vez que o Viandier não apresenta essa receita.

Especiarias moídas. Pegue uma onça e mais uma pequena quantidade de gengibre branco, um quarto de canela selecionada, meio quarto de uma onça de cravos e grãos do paraíso, e um quarto de açúcar, e reduza tudo a pó.

Até o início do século XVI, não mais que dez por cento das receitas francesas utilizavam açúcar, considerado um medicamento destinado aos pratos de doentes ${ }^{245}$. No Viandier, o açúcar é raramente utilizado nas receitas anteriores ao século XV. Apenas dez dessas receitas utilizam açúcar e apenas duas delas utilizam carne (de ave em ambos os casos). Destas dez, quatro pertencem à seção de "pratos para doentes", o que ilustra o caráter de medicamento conferido a esse condimento.

A tabela abaixo apresenta as receitas do Viandier, anteriores ao século XV, que utilizam açúcar.

Tabela 13 - Receitas que apresentam açúcar no Viandier

\begin{tabular}{|l|c|c|c|c|c|c|c|}
\hline \multicolumn{1}{|c|}{ RECEITA } & SEÇÃO & TIPO DE & ESPÉCIE & \multicolumn{2}{c|}{$\begin{array}{c}\text { CONSTANTE NOS } \\
\text { CARNE }\end{array}$} \\
\hline Frumento & Entremezes & & & VAL & BN & MAZ & VAT \\
\hline Fatias & Entremezes & & & VAL & BN & MAZ & VAT \\
\hline Cuminade de peixe & Sopas gordas & peixe & & VAL & BN & MAZ & VAT \\
\hline Filhote de lampreia & Sopas gordas & peixe & lampreia & & & MAZ & \\
\hline Um molho amarelado de peixe & Sopas gordas & peixe & $\begin{array}{c}\text { lúcio } \\
\text { perca }\end{array}$ & VAL & BN & MAZ & VAT \\
\hline Caldo de frango & Pratos para doentes & ave & frango & VAL & BN & MAZ & VAT \\
\hline Sopa de aveia & Pratos para doentes & & & VAL & BN & MAZ & VAT \\
\hline Caldo de perca & Pratos para doentes & peixe & perca & VAL & BN & MAZ & VAT \\
\hline Manjar branco de capão & Pratos para doentes & ave & capão & VAL & BN & MAZ & VAT \\
\hline Pudins e tortas na Quaresma & Viandas para Quaresma & $\begin{array}{c}\text { peixe } \\
\text { peixe } \\
\text { peixe }\end{array}$ & $\begin{array}{c}\text { lúcio } \\
\text { carpa } \\
\text { enguia }\end{array}$ & VAL & BN & MAZ & VAT \\
& & & & & \\
\hline
\end{tabular}

${ }^{245}$ LAURIOUX, Bruno. A Idade Média à mesa. Tradução Elsa Andringa. Sintra: Publicações EuropaAmérica, 1989, p. 42. 


\subsection{A carne nas cortes e nas festas}

Os locais de nascimento da arte culinária medieval são as cortes principescas, os castelos, os mosteiros e as cidades. Locais chamados por George Duby de "ilhas de gula", onde se podia comer muito e, frequentemente, comer bem.

O mais importante nas reuniões em que se comia e bebia na vida coletiva medieval era o comer e beber junto e não o que se comia e bebia. Na Alta Idade Média, em comparação com a época cortês, dava- se menos importância a pratos refinados. Foi por volta do século XII que ocorreu uma transformação estrutural e a festa organizada pelo senhor marcou o que se chamou de cultura cortês. A festa evoluiu de símbolo de laços de solidariedade para festividade senhorial. Muitos elementos persistiram como refeições, presentes, divertimentos a cargo de menestréis, momos e músicos, combates e partidas de caça. Mas as festas corteses passaram a exteriorizar ligações de poder e explicitar uma hierarquia existente no seio da comunidade. Os pratos e bebidas também passaram a refletir a condição de quem os oferecia e suas características são mais comprovadas pela literatura cortês do que pela historiografia ${ }^{246}$. A mesa deixou de ser o lugar de coesão, de reunião em torno do chefe, para tornar-se, antes de tudo, o local da exclusão social, da separação ${ }^{247}$. A carne se tornou emblemática do banquete aristocrático.

A partir do século XIII, o principal atributo do comando passou a ser a capacidade administrativa e diplomática, e não a força física e a habilidade no combate. A função do banquete tornou-se um instrumento social e político. Os medievais valorizavam a prodigalidade e a variedade de pratos servidos, assim como o número de convidados, os quais manifestavam a riqueza, o poderio e a generosidade do anfitrião. A capacidade de um senhor de organizar sabiamente um aparato de cozinha e mesa em torno de si superava a importância simbólica de sua capacidade individual de consumir grande quantidade de alimentos. As cortes se caracterizavam, mais do que um foco de poder militar, um pequeno universo social, que exaltava uma forma de vida na qual o ócio e o gozo eram os valores mais importantes e significativos. Elas delimitavam o espaço separado da aristocracia e alimentavam suas tradições, impondo a superioridade

\footnotetext{
246 ALTHOFF, Gerd. Comer compromete: refeições, banquetes e festas. In: FLANDRIN, Jean Louis; MONTANARI, Massimo. (org.). História da alimentação. Tradução Luciano Vieira Machado; Guilherme J. F. Teixeira. São Paulo: Estação Liberdade, 1998, p. 300-310.

${ }^{247}$ MONTANARI, Massimo. A fome e a abundância: história da alimentação na Europa. Tradução Andréa Doré. Edusc: São Paulo, 2003, p. 119.
} 
sobre o ambiente confuso que predominava a seu redor, acentuando as diferenças e tornando-as ostensivas. Procuravam provar, dessa maneira, que sua riqueza era antiga e e não podia ser confundida com grupos burgueses, nem mesmo com o patriciado das cidades. Foi a resposta social dos nobres a seu sentimento de surpresa, repugnância e desprezo: a diferença deveria ser demonstrada com sua simples presença, a forma de vida deveria delatar o direito legítimo de continuar sendo superior. No entanto, não puderam ser impermeáveis à profanidade que o realismo burguês trazia consigo, uma vez que seu apego à tradição era cada vez mais anacrônico. E a concepção profana da vida cortesã punha em xeque os fundamentos da posição privilegiada ${ }^{248}$.

Os rituais sociais das camadas elevadas da sociedade representavam a oposição elementar entre dominantes e dominados. O consumo de alimento e a forma como se dava esse consumo são instrumentos de demonstração de poder ${ }^{249}$. São bastante conhecidos os entremezes espetaculares dos festins medievais. Patês-gaiola, que cortados desprendiam pássaros vivos, e pratos cenário são característicos dos séculos XIV e XV. O Viandier propõe vários deles. Costumava-se levar à mesa grandes aves emplumadas e sem dúvida era uma enorme dificuldade tirar a pele da ave sem danificála, assar a carne e depois recolocar na pele para servir ${ }^{250}$. Alguns pratos apresentados como entremezes não eram sequer comestíveis, mas pinturas e esculturas que utilizavam materiais como tela e pergaminho, madeira, chumbo e tecido. Mesmo assim, constavam em livros de receitas, como é o caso do Viandier.

A tabela a seguir apresenta as receitas de entremezes constantes no Viandier (considerando apenas as anteriores ao século XV).

Tabela 14 - Receitas de entremezes constantes do Viandier

\begin{tabular}{|c|c|c|c|c|c|c|c|}
\hline RECEITA & $\begin{array}{l}\text { MODO DE } \\
\text { PREPARO }\end{array}$ & $\begin{array}{l}\text { TIPO DE } \\
\text { CARNE }\end{array}$ & ESPÉCIE & \multicolumn{4}{|c|}{$\begin{array}{l}\text { CONSTANTE NOS } \\
\text { MANUSCRITOS }\end{array}$} \\
\hline Falso grenon & $\begin{array}{l}\text { cozido } \\
\text { cozido } \\
\end{array}$ & $\begin{array}{c}\text { ave } \\
\text { quadrúpede }\end{array}$ & $\begin{array}{c}\text { ave doméstica } \\
\text { Vitela }\end{array}$ & VAL & $\mathrm{BN}$ & MAZ & VAT \\
\hline Delicado & cozido & ave & & VAL & $\mathrm{BN}$ & & VAT \\
\hline Frumento & cozido & & & VAL & $\mathrm{BN}$ & MAZ & VAT \\
\hline Fatias & cozido & & & VAL & $\mathrm{BN}$ & MAZ & VAT \\
\hline
\end{tabular}

\footnotetext{
${ }^{248}$ ROMERO, José Luis. Crise e ordem no mundo feudo burguês. Tradução Zilda H. S. Silva. São Paulo: Palíndromo, 2005.

${ }^{249}$ MONTANARI, Massimo. A fome e a abundância: história da alimentação na Europa. Tradução Andréa Doré. Edusc: São Paulo, 2003, p. 118-119.

${ }^{250}$ FLANDRIN, Jean-Louis. A distinção pelo gosto. In: ARIÉS, Philippe; DUBY, Georges. (Dir.). História da vida privada: da Renascença ao Século das Luzes. Tradução Hildegard Feist. São Paulo: Companhia das Letras, v. 3, 2009, p. 278-279.
} 


\begin{tabular}{|l|c|c|c|c|c|c|c|} 
Milhete & cozido & & & VAL & BN & MAZ & VAT \\
\hline Aves recheadas & assado & $\begin{array}{c}\text { ave } \\
\text { quadrúpede }\end{array}$ & $\begin{array}{c}\text { galinha } \\
\text { carneiro } \\
\text { Vitela }\end{array}$ & VAL & BN & MAZ & VAT \\
\hline Sem nome & cozido & ave & galinha & & BN & MAZ & \\
\hline Geléia de peixe ou carne & cozido & $\begin{array}{c}\text { quadrúpede } \\
\text { peixe }\end{array}$ & & VAL & BN & MAZ & VAT \\
\hline Lampreias frescas em molho apimentado & assado & peixe & lampreia & VAL & BN & & VAT \\
\hline Lampreia à galantina & cozido & peixe & lampreia & VAL & BN & MAZ & VAT \\
\hline Arroz fantasia & cozido & & & VAL & BN & & VAT \\
\hline Cisne revestido & assado & ave & Cisne & VAL & BN & & VAT \\
\hline Sálvia fria & cozido & ave & & VAL & BN & MAZ & VAT \\
\hline Ensopado de leitão & cozido & quadrúpede & Leitão & VAL & BN & MAZ & VAT \\
\hline
\end{tabular}

Na tabela abaixo estão relacionados os entremezes artísticos que constam como "receitas" no Viandier, embora façam parte de uma seção adicionada posteriormente ao século XIV. É interessante observar que nenhuma dessas "receitas" apresenta qualquer elemento comestível.

Tabela 15 - Entremezes artísticos constantes do Viandier

\begin{tabular}{|l|c|}
\hline \multicolumn{1}{|c|}{ RECEITA } & $\begin{array}{c}\text { CONSTANTE NOS } \\
\text { MANUSCRITOS }\end{array}$ \\
\hline O cavaleiro do cisne & VAT \\
Uma Torre & VAT \\
São Jorge e sua criada & VAT \\
Santa Marta & VAT \\
Entremezes mais fáceis & VAT \\
\hline
\end{tabular}

Nos banquetes eram servidos inúmeros pratos simultaneamente, em vários serviços. Iniciavam-se em geral com frutas e saladas, seguidas de sopas e caldos. Os assados de carne com molhos eram o centro da refeição, após os quais se apresentavam os entremezes. E se encerrava o banquete com queijos, doces, frutas cristalizadas e, por último, confeitos de especiarias. Era sofisticada a elaboração dos pratos. Assados eram servidos em travessas ou terrinas e era honrosa a tarefa do trinchador, ou trinchante, que tornava os pedaços fáceis de manusear. Ingredientes eram picados ou pilados, transformados em tortas, pastéis ou bolinhos. Aos assados em chama direta ou cozidos, acrescentavam-se os molhos, quase sempre azedos, à base de vinho, vinagre, agraço ou suco de frutas cítricas, engrossados com migalhas de pão, gemas, amêndoas moídas, sangue ou carne amassada em pilão. Algumas vezes continham também açúcar, uvas, 
ameixas ou cerejas. Um molho não cozido de bastante destaque no Viandier é o camelino, de gengibre e canela. O mais destacado dos molhos cozidos é o preto, de pimenta, escurecido com pão tostado ${ }^{251}$.

O banquete medieval francês ${ }^{252}$ utilizava o serviço chamado "à francesa"253, no qual os pratos são justapostos. Sucediam-se diversos serviços por refeição e em cada um deles eram apresentados vários pratos. Começava-se com um aperitivo, com vinho, bolo e frutas. Nos serviços seguintes sucediam-se os ensopados, assados e entremezes. O entremez era o momento principal, e nele a refeição era interrompida, para dar lugar às atrações: malabaristas, acrobatas, músicos e domadores. Mas o termo designava também o tipo de prato servido a essa altura, alguns muito simples, enquanto outros, verdadeiras obras de arte. Tratava-se de mais uma oportunidade para exibição de poder e riqueza. Terminava-se com os chamados "sobejos de mesa", conservas, bolos, pudins e frutas secas; a "saída", licor e bolos leves; e o "bota-fora", especiarias e vinho servidos costumeiramente em outra sala.

Quando as posses do anfitrião não permitiam esse esquema completo, os serviços se reduziam, assim como o número de pratos em cada um. Quase sempre mantinham a sucessão ensopado/sopa, assado, entremez, que constituíam a refeição propriamente dita. Mas a maioria dos convidados só tocava em um ou dois pratos por serviço e, dessa forma, a disposição destes sobre a mesa, longe de ser aleatória, revestiase de grande importância ${ }^{254}$. E se mesmo nas cortes principescas, a maior parte das calorias das dietas provinha de cereais, sendo vinho, carne, peixe, legumes, gorduras e queijo sempre acompanhamento do pão ${ }^{255}$, quanto mais alta a posição do indivíduo na hierarquia social medieval, maior a quantidade e a diversidade do acompanhamento ${ }^{256}$.

A cozinha senhorial ficava, desde o século $X$, na cave ou em anexos isolados da habitação, sempre separada da sala onde se realizava a refeição, o que fazia com que os alimentos chegassem frios à mesa. Comida quente era luxo e os pratos cobertos

\footnotetext{
${ }^{251}$ Apenas com a cozinha renascentista italiana é rompida a tradição culinária medieval: diminuem consideravelmente receitas de purês e mingaus e passa-se a empregar grande variedade de legumes e verduras, ervas e temperos de hortas. Aparece a influência da cozinha árabe, vinda do intercâmbio com o Oriente, o hábito de polvilhar açúcar e temperos, o emprego de arroz, tâmaras, romãs e laranjas amargas.

${ }^{252} \mathrm{~A}$ estrutura das ementas inglesas do período era mais confusa e os assados eram servidos em todos os serviços.

${ }^{253}$ No serviço “à russa”, frequente no século XIX, os pratos são servidos sucessivamente.

${ }^{254}$ LAURIOUX, Bruno. A Idade Média à mesa. Tradução Elsa Andringa. Sintra: Publicações EuropaAmérica, 1989, p. 91-95.

${ }^{255}$ STOUFF, Louis. Ravitaillement et alimentation em Provence aux XIV e XVe siècles. Paris: Mouton, 1970.

${ }^{256}$ LAURIOUX, op. cit., p. 22.
} 
destinavam-se aos grandes ou aos hóspedes homenageados. Tais cozinhas eram equipadas para diversos tipos de operações culinárias e, além da lareira central, existiam lareiras secundárias e grande variedade de utensílios. Era comum, nas casas principescas, a cozinha tapada, onde eram preparadas as refeições destinadas ao senhor e aos hóspedes, e outra, onde se preparava as refeições dos empregados. Também nos mosteiros beneditinos, a cozinha do abade era separada da dos monges e havia outras, destinadas ao preparo de alimentos dos hóspedes e dos doentes ${ }^{257}$.

Abaixo segue um trecho da descrição que o Ménagier fez do banquete oferecido pelo abade de Lagny ao Monsenhor de Paris, o presidente, o procurador, o advogado do rei e o restante do conselho (16 pessoas):

O Monsenhor de Paris tinha três escudeiros dele mesmo para servi-lo e era servido à parte com pratos cobertos. E monsenhor, o presidente, tinha um escudeiro e era servido à parte, mas não com pratos cobertos. Por ordem do monsenhor, o presidente, o procurador do rei era sentado acima do advogado do rei (POWER, 2008, p. 80) ${ }^{258}$.

Nas cortes, os banquetes eram frequentes e oferecidos não só por ocasião de bodas, cerimônias fúnebres e datas comemorativas, mas às altas personalidades de passagem e a seus acompanhantes e familiares. Entre a pequena nobreza e a burguesia as ocasiões eram mais raras, limitando-se quase sempre a bodas e funerais. Mesmo entre a aristocracia, as refeições diárias eram mais monótonas que as oferecidas em banquetes e festas. Os funerais e festins aristocráticos serviam para dar a medida do poder de quem os organizava e por essa razão o gasto descomunal era obrigatório e o muito que não se consumia não se reaproveitava, mas era dado aos pobres como demonstração de prodigalidade e caridade cristã. Os ricos também não comiam toda a porção de pão a que tinham direito. Nas mesas nobres e burguesas, as carnes eram colocadas sobre fatias de pão e ensopadas com o molho, depois eram oferecidas aos cães ou novamente aos pobres $^{259}$.

O maior cuidado quanto ao refinamento dos pratos acontecia nas cozinhas palacianas de grandes príncipes, como nas dos duques de Sabóia, dos duques de Borgonha e dos reis franceses. Mas muitas tiragens impressas do Viandier permitiram, a

\footnotetext{
${ }^{257}$ LAURIOUX, Bruno. A Idade Média à mesa. Tradução Elsa Andringa. Sintra: Publicações EuropaAmérica, 1989, p. 73.

${ }^{258}$ POWER, Eileen. The Goodman of Paris: a treatise on moral and domestic economy by a citizen of Paris, c.1393. New York: Boydell Press, 2008.

${ }^{259}$ LAURIOUX, op. cit., p. 23-89.
} 
partir do século XV, que uma elite não tão elevada pudesse participar também de um universo culinário próprio à altíssima nobreza ${ }^{260}$.

O Viandier não apresenta nenhuma sugestão de cardápio. Mas sabemos que na Inglaterra, na ocasião da coroação de Henrique IV, em 1399, foram servidos primeiramente peitos de capões em molho de pimenta, carne real, cabeça de javali armada, carne de quadrúpedes, faisão, garça real, tortas lombardas, esturjões e lúcios grandes e entremez. Em seguida, carne de caça em papa doce de farinha, galantina, leitão recheado temperado, pavão, grou, carne de caça assada, coelho, alcaravão, galinha dourada, grandes empadas recheadas, peitos de capão fritos, fatias lombardas e entremez. Por fim, manjar da Síria, marmelos em conserva, garça-real, maçarico-real, perdizes, pombos, condornizes, galinholas, passarinhos, láparos, peitos de aves em fatias, ovos em geleia, fritadas, guloseimas, empadinhas, tigelas de lírio e entremez ${ }^{261}$.

Quando a relação entre status social e alimentação passa, na Europa ocidental, na Baixa Idade Média, do caráter quantitativo para o qualitativo, é necessário entender que ainda prevalecia nas mesas dos ricos e poderosos uma enorme quantidade de alimentos. O que ocorria é que não se esperava mais que esses alimentos fossem consumidos.

A cultura do esbanjamento está intimamente ligada à cultura da fome, e dela não se pode apartar, caso queiramos compreender tal problemática com mais profundidade. Dialeticamente, ambos, fome e desperdício, exprimem-se reciprocamente, o que independe do fato da cultura erudita poder ou não ser portadora de um conteúdo autenticamente popular. Elas coexistem como expressões opostas de diversas categorias sociais, mas também coexistem em cada uma delas. Os privilegiados conhecem também o medo da fome, ao menos o medo de que o aprovisionamento não corresponda às suas elevadas expectativas. Já os camponeses também esbanjavam alimentos nas grandes festividades.

O burguês tinha, talvez mais do que o nobre, a necessidade de enaltecer a riqueza e a ascensão social. No entanto, por mais que a burguesia tenha buscado um modo de vida refinado, orientado pelo modelo aristocrático e sua culinária particular, quase sempre era necessária adequação considerável, já que os recursos necessários seriam demais para a maioria dos lares burgueses. Desse modo, a burguesia buscou um

260 TREFZER, Rudolf. Clássicos da literatura culinária: os mais importantes livros da história da gastronomia. Tradução Marcelo Rondinelli. São Paulo: Senac, 2009, p. 25.

${ }^{261}$ AUSTIN, Thomas. Two fifteenth-century cookery books. Londres: Early English Text Society Original Series, 2004. 
requinte inspirado na aristocracia, mas que terminou por se afastar do luxo perdulário e dos preparos trabalhosos, resultando numa maior austeridade.

No Ménagier são apresentadas vinte e quatro opções de cardápios, todos eles com diversos serviços e variados pratos, o que sugere se destinarem a ocasiões festivas ou banquetes. Também são apresentados exemplos de banquetes ${ }^{262}$, que são detalhadamente descritos, desde o preparo das mesas à apresentação dos cardápios e pratos específicos, passando pela decoração e disposição das iguarias e serviços prestados aos participantes, assim como a posição dos principais participantes à mesa. Abaixo segue um exemplo de cardápio constante no Ménagier:

I - Jantar para um dia de comer carne servido em trinta e um pratos e seis serviços:

Primeiro serviço: Vinho de Grenache e assados, tortas de vitela, empadas de enguias pequenas, chouriços de sangue e salsichas.

Segundo serviço: Guisado de lebre e costeletas, purê de ervilhas, carne salgada e de caça, um soringue ${ }^{263}$ de enguias e outros peixes.

Terceiro serviço: Assados: coelhos, perdizes, capões etc., grandes lúcios, robalos, carpas e guisados.

Quarto serviço: Aves do rio no molho dodine, arroz fantasia $^{264}$, recheio com molho picante e enguias abertas.

Quinto serviço: Empadas de cotovia, rissoles, leite com toucinho e flãs açucarados.

Sexto serviço: Peras e confeitos, nêsperas e nozes descascadas. Hipocraz e coscorões.

Os membros das confrarias, associações piedosas de devotos ou de artesãos de um mesmo ofício realizavam banquetes anuais, no dia do santo padroeiro, nos quais

\footnotetext{
${ }^{262}$ Almoço oferecido pelo Abade de Lagny ao Monsenhor de Paris, ao procurador e ao advogado do rei, bem como ao restante do conselho (16 pessoas). Festa de casamento que Mestre Helve teria dado numa terça-feira de maio (40 pessoas). Casamento Haute Court no mês de Setembro ( 40 pessoas).

${ }^{263}$ Um soringue é um caldo espesso. O nome é inspirado da forma de cocção da carne, sossenguar (em catalão ou provençal). A carne previamente assada ou parboilizada é frita (sempre com cebolas) e, posteriormente, sempre fervida num caldo de especiarias.

${ }^{264}$ Viandier: Ris engoulé. Arroz fantasia: Selecionar o arroz, lavar totalmente em água quente e deixar secar no fogo. Cozinhar fervendo em leite de vaca. Adicionar açafrão em pó no leite, para dar-lhe uma cor castanho-avermelhada, e gordura do caldo de carne da panela ( $\mathrm{O}$ termo engoullé é derivado de goules, vermelho, produzindo a ideia de decoração, fantasia).
} 
consumia-se bastante carne e vinho. A Confraria de São Nicolau de Guérande previa, para trinta pessoas, dez cabritos, quatro vitelas, dois pratos de peixe, quartos de porco, cinquenta e sete frangos, vinte e cinco queijos, sessenta e nove empadas e cento e quarenta e três tortas pequenas. A função dessas festas era estreitar a amizade entre os participantes e promover uma variação na dieta quotidiana ${ }^{265}$.

Nas festas campesinas o camponês se regalava com uma comida excepcional, carne fresca de carneiro e, conforme a região, talvez coelho, perdiz ou codorna, resultantes de uma caça furtiva. Algumas vezes, misturavam-se com os senhores nessas ocasiões, tendo oportunidade de observar costumes de pessoas de uma condição diferente da sua ${ }^{266}$.

${ }^{265}$ LAURIOUX, Bruno. A Idade Média à mesa. Tradução Elsa Andringa. Sintra: Publicações EuropaAmérica, 1989, p. 89.

${ }^{266}$ ROMERO, José Luis. Crise e ordem no mundo feudoburguês. Tradução Zilda H. S. Silva. São Paulo: Palíndromo, 2005, passim. 


\subsubsection{Uma nova etiqueta}

A nobreza, herdeira da tradição secular, era o único grupo social com possibilidade de tentar manifestar um estilo de vida definido. A criação de uma forma de vida nobre já não era mais espontânea, mas sim um ordenamento deliberado e consciente, que visava intensificar traços que a diferenciassem de outras formas de existência. Diante dos novos interesses e valores, aos quais não podia resistir, a aristocracia levou ao extremo o zelo para encobrir essas tentações, ao mesmo tempo em que sucumbia a elas.

Na Alta Idade Média, fazia-se necessário, para a manutenção dos laços de solidariedade entre guerreiros, que os senhores distribuíssem alimentos e bebidas e participassem dos excessos. Já no final da Idade Média, a diferença social estava muito mais acentuada. A elite tinha hábitos de consumo parecidos com os do período clássico: homem superior moderado em contraposição ao bárbaro embriagado. Estes poderiam ser bárbaros internos (camponeses, pobres de todos os tipos) ou externos (povos da periferia da Europa, como eslavos ${ }^{267}$. Nas festas corteses a embriaguez já não era mais adequada. Se outros grupos preferiam praticar excessos, a elite preferiu investir no diferencial alimentar e no refinamento comportamental. $\mathrm{O}$ excesso passou a ser um ato indigno de "um homem superior", conforme atesta Romagnoli ${ }^{268}$.

O século XIV foi o momento de refinamento dos hábitos alimentares palacianos. $\mathrm{Na}$ tentativa de destaque diante da burguesia abastada, a nobreza deu valor, conforme se lê no poema cavaleiresco Erec, de Hartmann Von Aue, “ à conduta louvável”, mais do que “ à capacidade de se empanturrar". Essa conduta louvável compreendia as boas maneiras à mesa, a preciosidade dos ingredientes, o cuidado no preparo e a elegância na apresentação. ${ }^{269}$ As boas maneiras corteses implicam em uma ritualidade convival não

267 FERNANDES, João Azevedo. Selvagens bebedeiras: álcool, embriaguez e contatos culturais no Brasil colonial. 2004. 392 f. Tese (Doutorado em História) - Departamento de História, Universidade Federal Fluminense, Rio de Janeiro, 2004, p. 227-228.

${ }^{268}$ ROMAGNOLI, Daniela F. Guarda no sii vilan: as boas maneiras à mesa. In: FLANDRIN, Jean Louis; MONTANARI, Massimo. (Org.). História da alimentação. Tradução Luciano Vieira Machado; Guilherme J. F. Teixeira. São Paulo: Estação Liberdade, 1998, p. 507 (ressalte-se que na Chanson de Guillaume, o personagem é repreendido por se retirar da batalha e comer uma costela de javali, um pavão assado, um pão e dois doces, pois se ele escolheu comer dessa forma, não devia abandonar as suas armas. Mesmo assim, há exemplos de moderação no comportamento de heróis corteses, que aderiram à nova imagem do "guerreiro cristão", que se afirma nesse momento).

${ }^{269}$ RESLER, Michael. Erec by Hartmann von Aue: Translation, Introduction, Commentary. Philadelphia: University of Pennsylvania Press, 2004, passim. 
mais baseada na força, mas na elegância. As iguarias tornam-se mais refinadas nas cores, perfumes e sabores.

A invenção das "boas maneiras" determinou culturalmente os domínios do privilégio, e as maneiras "corteses" e "urbanas" se definiram como uma rejeição ao "plebeu"270. O fio condutor foi o abandono da promiscuidade e dos comportamentos grosseiros e o século XIII viu florescer por toda a Europa regras de comportamento social que determinavam introspecção, autocontrole e autodomínio ${ }^{271}$. Através do padrão de bom comportamento, a camada alta secular deu expressão à sua auto-imagem, definida no conceito de cortesia. O código dos cortesãos, que gravitavam em torno dos senhores feudais, surgiu nas cortes e se disseminou por estratos mais amplos. ${ }^{272}$.

A marca da nobreza não era mais a do guerreiro valente e insaciável, mas a do direito incontestável, herdado e garantido, símbolo da primazia social. A aristocracia palaciana substituiu gradativamente a nobreza guerreira e provocou um refinamento de costumes em todos os âmbitos da vida. Quando a nobreza de corte ocupou o lugar social da nobreza guerreira, o refinamento dirigiu as preferências para as carnes mais leves, brancas. No final da Idade Média, a mesa passou a ser um local de manifestação de hierarquias, e os homens medievais sabiam bem disso.

Desde a Alta Idade Média as regras de conduta passaram a ser fixadas em cartilhas de boas maneiras, conjuntos de bons modos à mesa, dirigidas à nobreza feudal. Mas no final da Idade Média esses manuais voltaram-se também à burguesia próspera e opulenta, que buscava orientar-se pelos hábitos da nobreza. Comia-se quase sempre com as mãos. Apenas sopas e mingaus eram comidos com colher, compartilhados entre os vizinhos de mesa. Cada um trazia consigo a própria faca, que servia para cortar e espetar alimentos. O garfo, de dois dentes, era usado apenas para servir a carne, cortada sobre uma tábua de madeira ou uma fatia de pão (tranchoir). A carne era retirada da escudela ou do prato comum com os dedos ${ }^{273}$ e pousada num trincho de madeira ou metal, sobre o qual repousava um pedaço de pão para absorver o molho ${ }^{274}$. Quando se

\footnotetext{
270 MONTANARI, Massimo. Rumo a um novo equilíbrio alimentar. In: FLANDRIN, Jean Louis; MONTANARI, Massimo. (Org.). História da alimentação. Tradução Luciano Vieira Machado; Guilherme J. F. Teixeira. São Paulo: Estação Liberdade, 1998, p. 382-386.

${ }^{271}$ ROMAGNOLI, Daniela F. Guarda no sii vilan: as boas maneiras à mesa. In: FLANDRIN, Jean Louis; MONTANARI, Massimo. (Org.). História da alimentação. Tradução Luciano Vieira Machado; Guilherme J. F. Teixeira. São Paulo: Estação Liberdade, 1998, p. 496-508.

${ }^{272}$ ELIAS, Norbert. O processo civilizador. Rio de janeiro: Jorge Zahar, 1994, passim.

${ }^{273}$ Por isso a insistência dos manuais de boas maneiras quanto ao asseio das mãos e boca.

${ }^{274}$ Não se consumia, idealmente, esse pão, que era posteriormente oferecido aos cães ou aos pobres.
} 
usava o garfo, era para frutas cozidas, não para carne. Colheres, copos e taças eram compartilhados $^{275}$.

A mesa utilizada no banquete medieval apresentava concepção adaptada às cortes itinerantes e à indiferenciação dos cômodos da habitação. Tratava-se de uma prancha de madeira sobre cavaletes, móvel, que era retirada assim que a refeição terminava, na qual o lugar de cada um obedecia a um código hierárquico. Em geral, sentavam apenas de um lado, o que limitava ainda mais o acesso a determinados pratos. Havia distinção dos lugares de honra: a extremidade alta, os lugares vulgares e a extremidade baixa. A distância em relação à mesa principal também era simbólica ${ }^{276}$.

A moda da celebração do bom gosto procurava tornar claro aos novos ricos que, mesmo com pompa e gasto, não poderiam se equiparar aos nobres dos velhos tempos, e que estavam ainda muito distantes de alcançar o topo da hierarquia social. É importante ter em mente que a ideia de que os homens são iguais não existia na Idade Média e era gratificante para os nobres se saberem superiores. O senso de domínio era franco; a pressão no sentido de controlar os impulsos, pequena; e as emoções pouco controladas oscilavam por vezes entre violentos extremos. Mas a forma de vida mais livre e desinibida, característica do cavaleiro, perdeu, progressivamente, seu espaço, até desaparecer por completo. Aumentou o confinamento do grupo superior nas cidades, o que colocou em evidência a diferença entre a vida rural e a urbana. O conceito de cortesia ganhou cada vez mais espaço, até ser substituído no século XVI por outro ainda mais repressivo, o de civilidade, como demonstrou Norbert Elias: "senhores e cavaleiros livres teriam que se transformar em servidores dependentes do rei". Segundo Norbert Elias, "a coerção social evoluiu para autocoerção", o que é notável principalmente nos modos à mesa e hábitos alimentares, que avançam no final da Idade Média "no limite do constrangimento e fronteira da vergonha"277.

\begin{abstract}
Quanto mais se diferenciam as várias funções sociais, mais complexa e mais intrincada se torna a estrutura básica de uma sociedade e mais dependentes as pessoas se tornam umas das outras em suas atividades e afazeres. O comportamento de cada vez mais pessoas precisa ser ajustado entre elas, o tecido das ações precisa estar organizado de modo cada vez mais preciso e firme, para que a ação individual cumpra ali sua função social (ELIAS, 1994, p. 316).
\end{abstract}

\footnotetext{
${ }^{275}$ LAURIOUX, Bruno. A Idade Média à mesa. Tradução Elsa Andringa. Sintra: Publicações EuropaAmérica, 1989, p. 96.

${ }^{276}$ LAURIOUX, op. cit., p. 95-96.

${ }^{277}$ ELIAS, Norbert. O processo civilizador. Rio de janeiro: Jorge Zahar, 1994, p. 135.
} 
O processo civilizador não resultaria de um planejamento ou controle consciente, mas da diferenciação das funções sociais e do aumento da dependência mútua entre as pessoas ${ }^{278}$.

O Delfim Humberto II, de Viennois, determinou com rigor, em 1336, em uma ordenança, a ementa das pessoas de sua casa. No almoço de domingo, o Delfím e a Delfina receberiam cada um duas empadas contendo uma galinha gorda cada uma, ou dois frangos; os barões e cavaleiros mais importantes, apenas uma empada, e os cavaleiros de ordem inferior deveriam dividir uma empada a cada dois. Os escudeiros, capelães e abades deveriam ter suas empadas recheadas com meia galinha grande ou meio frango, mais a oitava parte de uma fatia de porco e dividir cada empada por dois. E o pessoal inferior, que comia no refeitório, deveria receber empadas recheadas com um doze avos de fatia de porco e dividi-las por dois ${ }^{279}$.

Nesse contexto, a cidade não produziu modelos éticos e os burgueses esforçaram-se para imitar e assimilar o modelo aristocrático, principalmente na Itália, onde predominaram cortes feudoburguesas ${ }^{280}$. Uma prática adotada por pessoas ditas “de bem" estava justificada, da mesma maneira que hábitos de camponeses eram considerados condenáveis. ${ }^{281}$. As leis sumptuárias não tinham propriamente um significado moral que buscasse refrear o esbanjamento, mas a ordenação de uma burguesia recentemente enriquecida, que imitava comportamentos aristocráticos. Tais leis pormenorizaram a quantidade e a qualidade das iguarias servidas tanto aos nobres quanto aos burgueses ${ }^{282}$.

A maioria das pessoas comia duas vezes por dia. As crianças e os doentes, assim como visitantes que chegavam cedo e os que faziam enormes esforços físicos pela manhã, como camponeses, costumavam fazer três refeições, a primeira logo cedo, como nosso café-da-manhã. Em outros casos, comer três ou quatro vezes ao dia era mal visto. A primeira refeição seria nosso almoço, que era chamado jantar, prandium, quase sempre entre dez e onze horas da manhã. A segunda era a ceia, cena, entre dezesseis e

\footnotetext{
${ }^{278}$ ELIAS, Norbert. O processo civilizador. Rio de janeiro: Jorge Zahar, 1994, p. 312.

${ }^{279}$ MANTEYER, M. De. Le Menu general de Monsieur le Dauphi, Bullet: de la Soc. D’Études histor., scientif, et littéraires des Hautes-Alpes. 1941.

${ }^{280}$ LE GOFF, Jacques. Cidade. Tradução Flavio de Campos In: LE GOFF, Jacques; SCHMITT, JeanClaude. (Org.). Dicionário temático do Ocidente Medieval. São Paulo: Edusc, v. 1, 2006, p. 219-236.

${ }^{281}$ FLANDRIN, Jean-Louis. A distinção pelo gosto. In: ARIÉS, Philippe; DUBY, Georges. (Dir.). História da vida privada: da Renascença ao século das Luzes. Tradução Hildegard Feist. São Paulo: Companhia das Letras, v. 3, 2009, p. 267.

${ }^{282}$ LAURIOUX, Bruno. A Idade Média à mesa. Tradução Elsa Andringa. Sintra: Publicações EuropaAmérica, 1989, p. 28.
} 
dezenove horas. Mas no caso dos camponeses os horários variavam de acordo com o ritmo de trabalho exigido ${ }^{283}$.

Do desejo alimentar deriva um ideal estético. No medievo, bonito é ser gordo e o adjetivo tem carga sempre positiva. Apenas no século XVIII a magreza adquiriu status de valor e virtude, símbolo das novas ideologias preponderantemente burguesas. No XIX a ostentação passa à vulgaridade, à prática popular. Mas é só no final do século XX que a relação com o alimento inverte-se definitivamente e, para as elites, o medo do excesso substitui, valorativamente, o medo da fome ${ }^{284}$.

${ }^{283}$ CONTAMINE, Philippe. La vie quotidienne pendant la guerre de Cent Ans. Paris: Hachette, 1976, p. 228.

${ }^{284}$ MONTANARI, Massimo. A fome e a abundância: história da alimentação na Europa. Tradução Andréa Doré. Edusc: São Paulo, 2003, p. 211-212. 


\section{O VIANDIER, O MENAGIER E O FABLIAU DE COCAGNE: O PRAGMATISMO BURGUÊS E A UTOPIA POPULAR}

\subsection{LE FABLIAU DE COCAGNE}

A comparação entre "Viandier e Cocanha" busca compreender como a abundância alimentar aparece na cultura popular e o quanto essa abundância corresponde à realidade do grupo social mais alto, assim como investigar a carga simbólica que a utopia alimentar carregava.

Le Fabliau de Cocagne (1947 apud FRANCO JR, 1998) ${ }^{285}$ é datado de meados do século XIII. Esta versão francesa foi a primeira obra escrita conhecida que tratou diretamente do país da Cocanha. O texto apresenta 188 versos octossílabos de rimas simples, possivelmente obra de um poeta goliardo ${ }^{286}$. Segundo a crítica literária Lênia Márcia Mongelli, “sete capítulos compõem a 'história de um país imaginário', metáfora da abundância, ociosidade, juventude e liberdade" 287 .

Trata-se de uma utopia. Além de ser um produto do imaginário social, funciona como uma forma de resistência às adversidades do período. O século XIII correspondeu à regulamentação, ordenação e instituicionalização de um novo tipo de Estado que se esforçou em instaurar outro modelo de vida. A Cocanha é a antítese desse processo, pois encarada como uma superação imaginária do contexto em questão, não pretende ser um

\footnotetext{
${ }^{285}$ LE FABLIAU DE COCAGNE. Ed. V. Väänänen, Neuphilologische Mitteilumgen, 48, 1947, p. 336.

${ }^{286}$ Os goliardos eram clérigos, quase sempre pobres, que possuíam alta educação, mas não conseguiam trabalho na Igreja ou apoio real. Costumavam recitar versos, alto e em latim, muitas vezes sobre a miséria de sua condição.

${ }^{287}$ MONGELLI, Lênia Marcia de Medeiros. O país da Cocanha: a imagem de uma utopia medieval. Jornal da Tarde, São Paulo, 07 nov. 1998. Caderno de Sábado, p. 3.
} 
modelo a ser construído, mas uma válvula de escape para os conflitos cotidianos. "A Cocanha é a utopia do instante, no instante" 288 .

A abundância cocaniana resulta do insaciável desejo de comer. O sonho da oferta ilimitada gera a demanda ilimitada. Segundo Marc Bloch:

\begin{abstract}
as características alimentares ajudam a entender as reações emocionais dos grupos humanos: no caso cocaniano, pode-se relacionar a desmesura alimentar à lassidão (e consequentemente à ociosidade), à despreocupação (logo à juventude), ao hedonismo (portanto ao sexo livre) (Bloch, 1963, p. $27)^{289}$.
\end{abstract}

A análise acerca da abundância no país da Cocanha, apesar de ser a mais expressiva, não pode ser tomada como única via de estudo. Não apenas o caráter quantitativo, mas também o qualitativo, ajudam a revelar aspectos do imaginário social.

A contribuição da história da alimentação para a compreensão desse momento histórico que corresponde a vazios materiais e imateriais é fundamental. Os hábitos alimentares descritos no fabliau revelam rupturas e permanências de uma sociedade em conflito. Não basta conhecer qual a alimentação dos homens medievais. Mais do que isso, é necessário analisar quais os sonhos contidos na Cocanha para entender o imaginário social daquele período.

A palavra utopia foi criada por Thomas More (1478-1535 d.C.) para designar uma ilha imaginária, numa obra crítica à sociedade de sua época. Desde então, a palavra passou a indicar qualquer sociedade idealizada, "concebida como evasão do concreto ou proposta de mudanças dele" 290 . Portanto, o termo também pode ser utilizado em relação a períodos históricos anteriores.

Utopia é também uma "manifestação sócio-cultural-psicológica que responde às deficiências de cada momento" 291 . É, em outras palavras, uma contraimagem da realidade. Tal conceito pode ser uma expressão de desejos coletivos de perfeição e, muitas vezes, expressa o retorno a uma suposta condição primordial da humanidade.

As utopias podem ser divididas em utopias de evasão e utopias de reconstrução. As primeiras valorizam dados da natureza, prevalecendo o princípio de busca da satisfação dos instintos humanos. A utopia do país da Cocanha encaixa-se nessa classificação. Já as segundas privilegiam a cultura e a ordem idealizadas para a

\footnotetext{
${ }^{288}$ FRANCO JR, Hilário Cocanha: história de um país imaginário. São Paulo: Companhia das Letras, 1998, p. 233.

${ }^{289}$ BLOCH, Marc. Tecnique et évolution sociale: réflexions d'un historien. In: Mélages historiques. Paris: SEVPEN, 1963.

${ }^{290}$ FRANCO JR, Hilário. Cocanha: várias faces de uma utopia. São Paulo: Ateliê Editorial, 1998, p. 11.

${ }^{291}$ FRANCO JR, Hilário Cocanha: história de um país imaginário. São Paulo: Companhia das Letras, 1998, p. 19.
} 
manutenção dessa civilização imaginária, como ocorre em a República de Platão e Utopia de Thomas More ${ }^{292}$.

Uma utopia medieval é diferente das posteriores, pois nela os elementos míticos são muito mais acentuados. O mito é uma forma de conhecimento que articula questões espirituais e materiais de uma sociedade sem as poder solucionar, o que torna muito claro os conflitos: "dúvidas, ansiedades, medos, expectativas e sonhos de uma comunidade" 293 . O mito é uma ponte entre o mundo abstrato e uma realidade concreta. "Aquilo que o homem perdeu na história, narrada pelo mito, ele busca através da ideologia e recupera no além-história da utopia” ${ }^{, 294}$.

Fabliau é uma fábula moral de narrativa curta, em geral de 300 a 400 linhas, versos octossílabos e conteúdo cômico ou satírico, quase sempre anônima, que frequentemente apresenta, além da crítica social, escatologia, violência e conteúdo sexual. R Howard considera os fabliaux a primeira expressão do realismo literário na Europa $^{295}$. Este era um gênero literário comum do norte da França, introduzido entre os séculos XII e XIV. Tratava de diversos aspectos do cotidiano e apresentava, ao final, uma lição de moral. Era uma representação da "cultura intermediária", ou seja, o "denominador cultural comum a todos os segmentos sociais" ${ }^{296}$. O fabliau circulava nos meios urbanos e nas cortes feudais e era difundido pelos jograis, ou seja, fazia parte da cultura oral ${ }^{297}$. "O fabliau é um conto em versos para rir”, segundo a definição Joseph Bédier ${ }^{298}$. Um dos primeiros escritores conhecidos de fabliaux é Rutebeuf, nascido em Champagne, por volta de 1248, mas que mudou-se para Paris onde tornouse jongleur ${ }^{299}$ nas ruas, mercados e praças próximos a Montagne Sainte-Geneviève.

Como todo fabliau, a Cocanha é uma utopia intrínseca a um imaginário coletivo, produto da oralidade:

\footnotetext{
${ }^{292}$ FRANCO JR, Hilário Cocanha: história de um país imaginário. São Paulo: Companhia das Letras, 1998 , p. 20.

${ }^{293}$ Idem. As utopias medievais. São Paulo: Brasiliense, 1992, p. 12.

${ }^{294}$ Ibidem, p. 13.

${ }^{295}$ BLOCH, R, Howard. Medieval French Literature and Law .University of California Press, 1977, passin.

${ }^{296}$ FRANCO JR. A Eva Barbada. Ensaios e Mitologia Medieval. São Paulo: EDUSP, 1996. p. 31-44

${ }^{297}$ Ibdem ,2001, p. 67

${ }^{298}$ BÉDIER, Joseph. Les fabliaux, études de littérature populaire et d'histoire littéraire du Moyen Âge Charleston: Nabu Press, 2011.

${ }^{299}$ O jongleur é um termo derivado do latim, joculatores, jogador ou ator. É um artista público que vaga pelas ruas da cidade.
} 
Por 'imaginário' entendemos um conjunto de imagens visuais e verbais gerado por uma sociedade (ou parcela desta) na sua relação consigo mesma, com outros grupos humanos e com o universo em geral. Todo imaginário é portanto coletivo, não podendo ser confundido com imaginação, que é uma atividade psíquica individual (FRANCO JR, 1998, p. 17).

Os sonhos de uma sociedade tendem a substituir a realidade, revelando o almejado, o buscado de uma coletividade. Jacques Le Goff afirmou que "o País da Cocanha é um sonho de protesto" contra os limites e "a domesticação das pulsões individuais e coletivas, que vão da confissão e da penitência à Inquisição, das leis e dos tribunais à prisão e ao patíbulo" $" 300$. Arthur Morton definiu a Cocanha como "paraíso da classe pobre": ela apresenta uma nova "Idade do Ouro", tenta superar no imaginário o que seria a principal dificuldade daquela sociedade, a falta de alimentos ${ }^{301}$.

A Cocanha é um mundo às avessas. A lenda parece ter sido sempre desconsiderada pelas camadas sociais melhor colocadas. Trata-se, portanto, de uma opulência diferenciada, ou seja, qualquer um pode se sentir um rei:

Aparentemente, a Cocanha foi imaginada naquele momento para desempenhar função compensatória para camadas sociais. Para o campesinato, apesar dos progressos agrícolas da época, ela era o sonho ainda não realizado da fartura total, obtida sem os enormes esforços cotidianamente despendidos. Para a burguesia em processo de formação, corpo estranho à sociedade feudal, ela era a concretização de ambições materiais (riquezas ilimitadas) e sociais (modo de vida nobiliárquico). Para a pequena e média aristocracia, era a fuga diante de transformações indesejadas, mas que se revelavam incontornáveis: fortalecimento do poder público, desenvolvimento da economia monetária, enfraquecimento dos laços servis. Para os estudantes universitários e os clérigos vagantes, era a superação das crescentes dogmatização e hierarquização eclesiástica (FRANCO JR, 1999, p. 9).

Mais adiante, Hilário Franco Jr afirma que:

A abundância responde à vontade de se opor à realidade vivida e sofrida por dupla insatisfação alimentar. De um lado, decorrência de uma produção ainda limitada pela natureza e por um progresso econômico que não eliminara inteiramente a carência e mesmo a fome, e de outro lado, decorrência da abstinência e dos jejuns impostos pela Igreja (FRANCO JR, 1999, p. 53).

Para o clero, tanto católico quanto protestante, a sensualidade e a irreligiosidade da Cocanha expunham o que havia de pior na natureza humana. Assim como o Carnaval, a Cocanha era uma anti-Quaresma que se opunha à privação penitencial ${ }^{302}$.

\footnotetext{
${ }^{300}$ FRANCO JR, Hilário. Cocanha: história de um país imaginário. Prefácio de Jacques Le Goff. São Paulo: Companhia das Letras, 1998, p. 8.

${ }^{301}$ MORTON, Arthur. L. The English Utopia. Londres: Lawrence and Wishart, 1952, p. 11-34.

${ }^{302}$ FRANCO JR, op. cit., p. 11-12.
} 
Ao longo de setecentos anos, o mito da Cocanha tem expressado os sonhos coletivos dos diferentes segmentos sociais. O fabliau apresenta uma sociedade sem leis e sem poderes constituídos, exaltando a ociosidade e o excesso tanto alimentar quanto sexual.

A característica alimentar da Cocanha revela-se, também, por sua definição etimológica:

a palavra pode ter vindo do Latim coquere ('cozinhar') ou do provençal cocanha ou cocagno, derivado talvez de coca, coque, isto é, casca do ovo ou de certas frutas. Ou do provençal coco, 'brioche', 'pão doce'. Ou ainda do médio alemão kokenje (modernamente kuchen, 'bolo') (FRANCO JR, 1998, p. 58).

Para contextualizar socialmente o fabliau é importante colocar em foco a obra cômica popular, o problema da cultura popular na Idade Média. As diversas manifestações do riso opunham-se à cultura oficial, ao tom sério religioso e feudal da época. Podemos dividir essa vasta gama de manifestações em três grandes categorias ${ }^{303}$ : 1) as formas de ritos e espetáculos (festejos carnavalescos, obras cômicas representadas nas praças públicas); 2) obras cômicas verbais (em latim ou língua vulgar); 3) diversas formas e gêneros do vocabulário familiar e grosseiro (insultos, juramentos).

Existe estreita relação entre a Cocanha, apresentada no fabliau, e os ritos e espetáculos medievais, principalmente o Carnaval. A nova forma de comunicação (resultante das festas carnavalescas) produziu novas formas linguísticas: gêneros inéditos, mudanças de sentido ou eliminação de certas formas desusadas. O novo tipo de relações familiares estabelecidas durante o Carnaval reflete-se, portanto, em uma série de fenômenos linguísticos.

Os festejos de Carnaval (com todos os seus atos cômicos) ocupavam um lugar importante na vida do homem medieval. Esses ritos e espetáculos apresentavam uma diferença em relação às formas do culto e das cerimônias oficiais da Igreja. Elas ofereciam uma visão de mundo deliberadamente não oficial, exterior à Igreja. Era uma "segunda vida", à qual os homens pertenciam em maior ou menor grau. Isso criava uma

\footnotetext{
${ }^{303}$ BAKHTIN, Mikhail. A cultura popular na Idade Média e no Renascimento: o contexto de François Rabelais. Tradução Yara Frateschi Vieira. São Paulo, Hucitec: Brasília Editora da Universidade de Brasília, 1987, p. 2.
} 
"dualidade do mundo" que se faz necessária para compreender a consciência cultural da Idade Média ${ }^{304}$.

O Carnaval ignora toda e qualquer distinção entre atores e espectadores. Eles não assistem ao espetáculo; eles vivem os espetáculos, uma vez que o Carnaval existe para todo o povo. Não há fronteira espacial. Durante a festa só se pode viver de acordo com suas leis, as leis da liberdade. O Carnaval possui um caráter universal; é um estado peculiar do mundo: o seu renascimento e a sua renovação, dos quais participa cada indivíduo. Ele é a segunda vida do povo, baseada no princípio do riso. É a sua vida festiva.

Por outro lado, as festas oficias da Idade Média não arrancavam o povo à ordem existente, não criavam essa segunda vida. A festa oficial tendia a consagrar a estabilidade, a imutabilidade e a perenidade das regras que regiam o mundo. Por isso o tom da festa oficial só podia ser o da serenidade e o princípio cômico lhe era estranho. A festa oficial traía a verdadeira natureza da festa humana e desfigurava-a. O Carnaval era o triunfo de uma espécie de libertação temporária da verdade dominante e do regime vigente, de abolição provisória de todas as relações hierárquicas, privilégios, regras e tabus. Essa eliminação provisória criava na praça pública um tipo particular de comunicação. As obras cômicas verbais da Idade Média estão imbuídas de concepções carnavalescas. Nelas, o riso era ambivalente e festivo. Estavam fundamentalmente ligadas aos festejos de tipo carnavalesco cuja parte literária costumava representar. Essa influência sobre o pensamento dos homens era radical: obrigava-os a renegar sua condição social: eclesiásticos de alta hierarquia e doutos teólogos permitiam-se alegres distrações durante as quais repousavam da sua piedosa gravidade ${ }^{305}$.

\footnotetext{
${ }^{304}$ BAKHTIN, Mikhail. A cultura popular na Idade Média e no Renascimento: o contexto de François Rabelais. Tradução Yara Frateschi Vieira. São Paulo: Hucitec; Brasília: Editora da Universidade de Brasília, 1987, p. 4.

${ }^{305}$ Ibidem, p. 6-12.
} 


\subsubsection{Conflitos, permanências e ausências}

A primeira menção à problemática da alimentação ocorre no verso trinta e um. Até este ponto, é feita uma apresentação do narrador por meio de um vocativo que revela traços da cultura oral presente em uma narrativa de origem popular, "coletiva" e com autor anônimo. É interessante observar que o narrador se apresenta como uma pessoa jovem e sábia que fora à Cocanha por ordem do Papa, a fim de pagar uma penitência (aspecto cômico). Ele considera que aqueles que habitam o país foram abençoados por Deus e por todos os seus santos.

No verso trinta e um são mencionados os peixes (barbos, salmões, sáveis e esturjões), que não aparecem na Cocanha como um símbolo de privação, e sim de gula. Uma possibilidade de interpretação é a de que o peixe, ao ser representado como as paredes e alicerces da moradia dos habitantes da Cocanha, revela que, no imaginário popular, era um dos alimentos mais importantes, embora menos consumido.

O porco é mencionado pela primeira vez no verso trinta e quatro (telhados de toucinho). Será o alimento mencionado ainda duas vezes ao longo do texto: verso trinta e cinco (cerca de salsichas) e verso trinta e sete (carne assada e presunto).

Se o porco era considerado o animal mais aparentado ao homem, tanto no plano alimentar e fisiológico, quanto no jurídico e espiritual, na Cocanha os porcos "estão acima (nos telhados), em volta (nas cercas) e dentro (no estômago, nas vísceras, no sangue) dos humanos. É a indiferenciação entre natureza e cultura"306. Comer carne de porco era simbolicamente canibalismo, como na comunhão cristã.

A carne de ave aparece especificamente no verso quarenta: (gordos gansos) e genericamente no verso cinquenta e quatro, como (carne de ave). A carne de ganso era servida com molho de alho, conforme mencionado no verso quarenta e dois, seguindo a recomendação constante no Viandier, como ilustrado na tabela abaixo. Nenhum outro legume verde ou fresco ou qualquer especiaria é mencionada.

\footnotetext{
${ }^{306}$ FRANCO JR, Hilário. O porco, o homem e Deus: a utopia panteísta da Cocanha. Revista USP, São Paulo, n. 50, p. 73, jun./ago. 2001.
} 
Tabela 16 - Receitas de ave constantes no Viandier

\begin{tabular}{|c|c|c|c|c|c|c|c|c|}
\hline RECEITA & $\begin{array}{l}\text { MODO DE } \\
\text { PREPARO }\end{array}$ & $\begin{array}{l}\text { TIPO DE } \\
\text { CARNE }\end{array}$ & ESPÉCIE & $\begin{array}{c}\text { MOLHO } \\
\text { RECOMENDADO }\end{array}$ & \multicolumn{4}{|c|}{$\begin{array}{c}\text { CONSTANTE NOS } \\
\text { MANUSCRITOS }\end{array}$} \\
\hline Gansos & assado & ave & ganso & $\begin{array}{c}\text { de alho branco } \\
\text { de pimenta preta } \\
\text { de alho verde } \\
\text { Jance } \\
\text { saintmerry }\end{array}$ & VAL & $\mathrm{BN}$ & MAZ & VAT \\
\hline
\end{tabular}

No verso cinquenta e quatro aparecem "outros tipos de carne": de cervo ou de ave. Em todo o fabliau nenhuma outra qualidade de carne é mencionada.

Os versos quarenta e nove e cinquenta enfatizam a ausência de oposição e proibição com relação ao consumo desenfreado de qualquer alimento disponível na Cocanha (carne). Tal elemento opõe-se a restrições e interdições clericais a respeito de hábitos alimentares. A Quaresma e seu jejum (verso oitenta e oito) só ocorreria a cada vinte anos. E, mesmo assim, quando era agradável jejuar (verso oitenta e nove). O verso noventa e três reitera que ninguém ousa proibir algo e os versos noventa e seis e noventa e sete, que não existe jejum.

O texto é anticlerical, pois subverte a liturgia, debocha da penitência, ignora o clero e perverte os valores cristãos. Trata-se de uma maneira simbólica de burlar o monopólio da manipulação do sagrado detido pelo clero.

Dos versos oitenta e um a oitenta e sete, o documento refere-se a quatro Páscoas, quatro festas de São João, quatro Vindimas, quatro Todos os Santos, quatro Natais, quatro Calendárias Anuais e quatro Carnavais. Nesta simbologia o número quatro representa a antítese do número três comum ao pensamento cristão (Pai, Filho e Espírito Santo). Enquanto quatro refere-se a expressões terrenas, como os elementos do mundo material, os tipos fleumáticos e as idades do homem, o número três possui um caráter espiritual $^{307}$.

A Cocanha apresenta uma relação de paralelismo com o Carnaval, festa de sentido subversor, criadora de um mundo ao contrário. Cocanha e Carnaval são concebidos como anti-Quaresma, em que a comida, a bebida e o sexo se opõem à privação penitencial $^{308}$. O Carnaval era a festa mais importante do final do inverno e expressava a alegria pelo renascer da natureza. Caracterizava-se pelo consumo excessivo de comida, de bebida e de sexo, pois o fato de os estoques de inverno estarem

\footnotetext{
${ }^{307}$ FRANCO JR, Hilário. Cocanha: história de um país imaginário. São Paulo: Companhia das Letras, 1998, p. 86.

${ }^{308}$ Embora em outras versões da Cocanha tal paralelismo apareça em tom de crítica.
} 
no fim não preocupava devido à chegada da primavera (carne vale). No entanto, como as produções primaveris ainda demorariam um pouco, seguia-se o caráter penitencial: a Quaresma. O Carnaval tornava-se o prelúdio da penitência. O carne vale era também o adeus à carne. Isso tornava ainda mais forte o contraste entre os dois eventos, como a oposição entre a manifestação da vida e os jejuns. A partir do século XIII tornaram-se comuns as alegorias do combate entre Carnaval e Quaresma.

Assim como a Cocanha, o Carnaval personificava a abundância e a explosão de energia. Por isso recorre-se à inversão com o uso de fantasias e máscaras, que na verdade revelam o "eu" mais profundo: o demônio interior que pode aflorar naquele momento num retorno simbólico ao caos primitivo.

O único cereal mencionado no fabliau é o trigo, no verso trinta e oito. Mas seu derivado, o pão, não é mencionado uma única vez. Uma interpretação possível para a ausência desse alimento na Cocanha é que sua presença cotidiana nas refeições medievais o tornava um alimento vulgar, que não caberia em um local de coisas extraordinárias. Ou ainda, de que pessoas ricas não comiam tanto pão quanto os camponeses $^{309}$. A sopa, alimento básico da alimentação camponesa, também está ausente no fabliau.

Na Idade Média, outros vegetais eram complementos fundamentais dos cereais, e eram cultivados intensivamente em hortas, presentes em todas as casas, tanto no campo quanto nas cidades. Consumia-se principalmente nabo, couve de várias espécies, cebola, alho-poró, alho e grande variedade de hortaliças, ervas, raízes e plantas aromáticas. A horta era tão importante na alimentação camponesa que, ao contrário de outras terras cultiváveis, era considerada "zona franca de rendeiros" e sobre ela não poderia ser exigido qualquer tributo ${ }^{310}$. A colheita das hortas era complementada pela coleta de aspargos, agrião, cogumelos, tomilho, manjerona, basílico, louro, funcho ou salva, coletados nas pradarias e nos bosques ${ }^{311}$. Mas esses alimentos foram omitidos no fabliau, provavelmente devido à sua banalidade e pouco prestígio nos círculos sociais feudais.

\footnotetext{
309 MONGELLI, Lênia Marcia de Medeiros. O país da Cocanha: a imagem de uma utopia medieval. Jornal da Tarde, São Paulo, 07 nov. 1998. Caderno de Sábado, p. 3.

${ }^{310}$ MONTANARI, Massimo. Estruturas de produção e sistemas alimentares. In: FLANDRIN, Jean Louis; MASSIMO, Montanari. (Org.). História da alimentação. Tradução Luciano Vieira Machado; Guilherme J. F. Teixeira. São Paulo: Estação Liberdade, 1998, p. 1998, p. 250.

${ }^{311}$ RIERA-MELIS, Antoni. Sociedade feudal e alimentação (séculos XII - XII). In: Ibidem, p. 406.
} 
As especiarias também foram omitidas ${ }^{312}$, o que revela que embora o grande desejo do consumo de carnes e peixes estivesse presente na Cocanha, parece não ter havido uma preocupação com o temperar, tão marcada nos livros de receita aristocráticos como o Viandier, conforme abordado anteriormente. Vale observar que em versões posteriores sobre o país da Cocanha, as especiarias foram mencionadas.

O uso de mesas postas com toalhas brancas é descrito nos versos quarenta e quatro e quarenta e cinco. Apenas num castelo ou em uma casa rica na cidade era montada uma mesa sobre cavaletes, em geral de frente para a lareira. O uso de uma mesa de quatro pés só foi difundido na França a partir do século XV. Entre as pessoas mais modestas da cidade ou do campo, as mesas eram raridades. As refeições eram feitas, de acordo com as estações, perto do fogo ou da porta, como uma fonte de luz natural. Muitos textos afirmam que se comia sobre um banquinho. A cadeira, quando existia, era única e de uso exclusivo do chefe da casa ou de um hóspede que se queria honrar. Até o final da Idade Média, a roupa branca era um luxo muito caro. Mesmo que algumas vezes se encontrasse uma toalha entre os bens dos camponeses, ela não era usada no dia-a-dia. Na cidade, as pessoas ricas possuíam toalhas de cânhamo para uso diário e de linho para festas. Os pobres possuíam apenas uma toalha para proteger a mesa e enxugar as mãos. ${ }^{313}$.

O pudim é o único alimento doce mencionado no texto, nos versos noventa e oito e noventa e nove. O açúcar em si não é mencionado. Tampouco as frutas são referidas (em versões posteriores da Cocanha são mencionadas frutas, principalmente os figos). Novamente há coincidência com a raridade do açúcar nas receitas do Viandier anteriores ao século XV, conforme já demonstrado.

Em qualquer de suas versões, a Cocanha é a “época de ouro", o paraíso alimentar da comida abundante e gratuita, a evasão de uma civilização caracterizada pela penúria ${ }^{314}$. Podemos considerar também que o consumo utópico da Cocanha, pelo menos no fabliau, é de carne, peixe e vinho. Se comparado com um livro de cozinha

\footnotetext{
${ }^{312}$ Segundo Hilário Franco Júnior, a ausência ocorre devido a três motivos: 1) os pratos mágicos da Cocanha eram perfeitos e completos e dispensavam qualquer aditivo de sabor ou de preservação. Além disso, 2) o caráter medicinal das especiarias não fazia sentido em uma terra onde não existem doenças. E 3) as especiarias eram consumidas principalmente no inverno e, na Cocanha, o clima era sempre primaveril.

313 PIPONNIER, François. Do fogo à mesa: a arqueologia do equipamento culinário no fim da Idade Média. In: FLANDRIN, Jean Louis; MASSIMO, Montanari. (Org.). História da alimentação. Tradução Luciano Vieira Machado; Guilherme J. F. Teixeira. São Paulo: Estação Liberdade, 1998, p. 516.

${ }^{314}$ DELUMEAU, Jean. O pecado e o medo: a culpabilização no Ocidente (séculos XII-XVIII). Tradução Álvaro Lorencini. Bauru: EDUSC, 2003, p. 234.
} 
aristocrático, como o Viandier, o sonho popular da Cocanha parece uma caricatura do banquete aristocrático, embora o preparo seja simplificado e o tempero praticamente desconsiderado. O empanturramento com as espécies é mais importante do que a apresentação elaborada. A hierarquia do banquete é suprimida : a utopia é igualitária. Se há mesas, pouco importa o lugar onde cada um se sentará. Nela desaparece a grande função do banquete do final da Idade Média: a demarcação da posição social com base no alimento e sua forma de apresentação. 


\subsubsection{Várias faces de uma utopia: versões posteriores da Cocanha}

Dos séculos XII ao XV são conhecidas oito representações iconográficas do tema. Dos séculos XVI ao XVII existem pelo menos doze versões francesas, vinte e duas alemãs, trinta e três italianas e quarenta flamengas ${ }^{315}$. A seguir, estabelecemos uma pequena comparação com Le fabliau de Cocagne e algumas versões da Cocanha, contemplando alimentos constantes nas receitas do Viandier:

The Land of Cokaiygne (poema inglês de fins do século XIII) - (1904 apud FRANCO JR., 1998, p. 33-46) $)^{316}$

Nesse poema, embora quase contemporâneo do fabliau, são mencionados frutas, azeite, leite, mel, bolo de farinha, gengibre, zedoária, noz-moscada, canela, cravo, cubeba e doce de leite. Os elementos comuns aos dois textos são o vinho, carne de porco, alho e o ganso assado. Esse poema é também bem mais erótico. Ou seja, essa Cocanha inglesa do século XIII parece ser ainda mais divertida que a francesa. Outro elemento interessante é a descrição de como alguém pode chegar à Cocanha: ficar mergulhado em excremento de porco (mais uma vez o porco) até o pescoço, por sete anos.

Vom Schlaraffenland (O País dos Tolos Alemão, assim são as mentiras, de princípios do século XIV) - (1836 apud FANCO JR., 1998, p. 47-53) $)^{317}$

O elemento mais interessante dessa versão é a importância conferida ao sal. Outros alimentos que estão ausentes no fabliau e aparecem aqui são o mel e o pão.

Bengodi (paródia italiana da Cocanha, de 1349 ou 1350) - (Bocaccio 1992 apud FRANCO JR., 1998, p. 55-60) $)^{318}$

\footnotetext{
${ }^{315}$ FRANCO JR, Hilário. Cocanha: várias faces de uma utopia. São Paulo: Ateliê Editorial, 1998, p. 9.

${ }^{316}$ LAND OF COKAYGNE. Ed. W. Heuser, Die Kildare-Gedichte. Die Altesten Mittelengischen Denkmäler in Anglo-Iricher Uberlieferung, Bonn, Hanstein, 1904, p. 141- 150.

${ }^{317}$ VOM SCHLARAFFENLAND. Ed. M. Haupt e H Hoffman. In: Autdeutshche Blätter, Leipzig, Brockhaus, 1836, v. 1, p. 163-170.

${ }_{318}$ BOCACCIO, Giovanni. Decameron. VIII. Ed. M. Marti, Milão, Rizzoli, 9 ed., 1992, v. II, p. 522-531.
} 
Nessa versão, os alimentos comuns ao fabliau são salsichas, ganso, vinho e porco, ao qual é dada bastante importância. Mas aqui são mencionados também o queijo, macarrão e ravioli.

Die it van date dele van Cockaengen (o país da Cocanha holandês, do século XV) - (1894 apud FRANCO JR., 1998, p. 61-68) ${ }^{319}$

O vinho, o peixe e a carne de porco são mais uma vez recorrentes. No entanto aparecem nessa Cocanha outros alimentos ausentes no fabliau, tais como pão, omelete, manteiga, enguia, gengibre, noz-moscada e cerveja.

Das Schalaweraffenlandt (O país dos preguiçosos, paródia alemã da Cocanha, de 1530) - (Sachs 1893 apud FRANCO JR., 1998, p. 77-85) 320

Essa versão menciona também a forma pela qual se chega à Cocanha. Dessa vez é mais agradável: comendo uma montanha de mingau. A carne de porco é mais uma vez o alimento mais mencionado (toucinhos, defumados, assados, lingüiças, leitoas). Aqui aparece pela primeira vez a alegoria do porco vivo e assado com uma faca nas costas. Os peixes e as aves são importantes e dessa vez, além dos gansos, faz-se alusão a frangos e pombos. Também é dada importância a frutas, doces e ovos: biscoitos, ovos mexidos, uvas, geléia, figos (defecados por burros), cerejas, cavalos que botam ovos. Existem ainda nessa Cocanha os pães, queijos e leite.

Van Luye Landt (A terra da gula, paródia holandesa da Cocanha, de 1546) (1944 apud FRANCO JR., 1998, p. 87-95) 321

Essa Cocanha é um pouco parecida com a anterior: aqui existem também os porcos que nascem assados com faca nas costas, os cavalos que botam ovos e os burros que botam figos. Além desses animais fantásticos, existem os cães que botam uvas moscatel e as vacas que botam panquecas verdes. Os alimentos são mais sofisticados que os do fabliau. Fala-se de doces, panquecas de ovos, frangos assados, mingau de trigo, tortas folhadas, pão de especiarias, nozes-moscadas e cravos, pastéis, peras assadas, leite doce, pão doce, balas de açúcar, queijo. O porco é, mais uma vez,

\footnotetext{
${ }^{319}$ DIE IT VAN DATE DELE VAN COCKAENGEN. Ed. R. PriebschTijdschrift voor nederlandsche Taal. In: Letterkunde, 13, 1894, p. 185-192.

${ }^{320}$ SACHS, Hans. Das Schalaweraffenlandt. Ed. E. Goetze. In: Samtliche Fabeln und Schwänke, Halle, Max Niemeyer, 1893, p. 8-11.

321 VAN LUYE LANDT. Ed. E. Ackermann. In: Das Schlaraffenland in German Literature and Floksong. Chicago: Univrsity of Chicago Press, 1944, p. 162-165.
} 
elemento importante (toicinho, salsichas de fígado, salsichas defumadas). O peixe e o ganso também são comuns ao fabliau. Mas aqui aparecem os frangos, pombos e galinholas. Os frangos são apreciados e jogados para fora das cercas. A punição para dívidas é passar um ano comendo frango assado e pão branco. Além do vinho, nessa Cocanha há menção à cerveja.

Jauja (paródia espanhola da Cocanha, de 1547) - (Rueda 1992 apud FRANCO JR., 1998, p. 97-104) $)^{322}$

O porco e o vinho estão presentes, como no fabliau. Mas aqui são mais uma vez mencionados mel, leite, ovos e queijo. Além disso, aparecem alimentos bem particulares: requeijão, perdizes, coelhos, fracolins, filhós, sonhos, confeitos, doce de abóbora, doce de cidra, marzipã, balas e arroz.

O reino de Panigon (de 1560) - (Huon 1953 apud FRANCO JR., 1998, p. 113$126)^{323}$

Ao porco é conferida a importância recorrente. Mais uma vez são mencionadas as alegorias dos cavalos que botam ovos e burros que botam figos. Entre os alimentos ausentes no fabliau e presentes aqui estão: mingau, manteiga, açúcar, queijo, bolos, biscoitos, morangos, pastel de carne de caça, pão branco, leite, frangos, tarambolas, frangos selvagens e castanhas. Comuns ao fabliau são também os peixes e o vinho.

Il piacevole viaggio di Cuccagna (Uma viagem italiana à Cocanha, de 1588) (Camporesi 1975 apud FRANCO JR., 1998, p. 131-143) ) $^{324}$

Essa versão faz bem menos menção aos alimentos que as demais. O porco e o vinho estão presentes, assim como no fabliau. É conferida relativa importância às frutas, especificamente aos figos e amêndoas. São citados perdizes e faisões, além de doces como confeitos e marzipãs.

\footnotetext{
${ }^{322}$ RUEDA, Lope de. Pasos, 5. Ed. Ollé González; V. Tusón. Madrid: Cátedra, 1992, p. 157-165.

${ }^{323}$ Familiere description du tres vinoporratimalvoise et tres envitaillegoulement royaume panigonnis, mystiquement interprete l'isle de Crevepance. Ed. A. Huon. In: Le Roy Sainct Panigon dans l'imagerie populaire du XVI sicle, en François Rabelais: ouvrage publié pour le quatriéme centenaire de sa mort. Genebra-Lille, Droz-Giard, 1953, p. 221-225.

${ }^{324}$ IL PIACEVOLE VIAGGIO DI CUCCAGNA. Ed. P. Camporesi. Apêndice de "Carnavale, Cuccagna e giuochi di villa". Studi e problemi di critica testuale, 10, 1975, p. 93-97.
} 
A canção espanhola de Chacona (do século XVII) - (Duran 1829 apud FRANCO JR., 1998, p. 145-150) $)^{325}$

O porco e o vinho são mencionados, mas não com grande destaque. Aparecem aqui, ao contrário do fabliau, pão, pães de leite, perus, perdizes, lebres, pombas, carneiros, francolins, galinhas e frangas.

São Saruê (A Cocanha brasileira, de 1947) - (Santos 1947 apud FRANCO JR., 1998 , p. $163-177)^{326}$

Nesse caso, como não poderia deixar de ser, os alimentos são bastante particulares. Fala-se de pão, leite, queijo e mel, além do porco e do vinho (os alimentos chave do fabliau). Mas também de coalhada, carne guisada, rapadura, café, feijão, arroz, manteiga, beijus, tapioca, pamonha, milho, pipoca, caldo de cana e açúcar refinado.

\footnotetext{
${ }^{325}$ Romancero de romances doctrinales, amatorios, festivos, jocosos, satíricos y burlescos sacados de varias colleciones generales y de lãs obras de diversos poetas de los siglos XV, XVI y XVII, 67. Ed. A. Duran. Madrid: Amarita, 1829, p. 282-283.

${ }^{326}$ SANTOS, Manuel Camilo dos. Viagem a São Saruê. Campina Grande: A Estrella da Poesia, s/d, 1947.
} 


\subsection{Le Ménagier de Paris}

Le Ménagier de Paris foi escrito por volta de 1394, por um burguês desconhecido, dedicado à sua jovem esposa, que não tinha mais do que 15 anos de idade. É um tratado de administração doméstica para um lar elegante, que além de extenso texto sobre cozinha, traz orientações sobre ética, moral, comportamento, trato com a criadagem, jardinagem, criação de cavalos e falcoaria ${ }^{327}$. As seções do Ménagier dedicadas à cozinha apresentam evidente influência do Viandier.

Grande parte das receitas do Ménagier é comum aos dois livros. Mas neste o modo de preparo é mais especificamente explicado, provavelmente não só por se tratar de um livro posterior, mas também porque seu público alvo não era constituído de cozinheiros profissionais, e sim donas de casa burguesas, algumas bastante inexperientes. Frequentemente é possível recorrer ao Ménagier para obter esclarecimento sobre passagens do Viandier que não podem ser entendidas facilmente.

As medidas raramente são especificadas e as instruções de preparo só podem ser consideradas detalhadas se comparadas com os livros do mesmo período.

${ }^{327}$ BRERETON, Georgine; FERRIER, Janet. (Org.). Le Ménagier de Parisi. Oxford: Oxford University Press, 1981. 


\title{
3.2.1 Um retrato da vida burguesa ${ }^{328}$
}

O tratado apresenta três seções com dezenove artigos principais. A primeira seção trata de normas religiosas e morais:

\begin{abstract}
É necessária para ganhar o amor de Deus e a salvação de sua alma e também para ganhar o amor de seu esposo e para dar-lhe neste mundo aquela paz que deveria existir no casamento. E devido a estas duas coisas, a saber, a salvação de sua alma e o conforto de seu marido, serem as duas coisas principais mais necessárias, daí estarem elas colocadas em primeiro lugar
\end{abstract}

Segue uma série de artigos instruindo como proferir orações matinais ao se levantar, como comportar-se na missa e de que forma fazer sua confissão ao padre; e uma longa incursão sobre os sete pecados capitais e suas virtudes correspondentes. $\mathrm{O}$ tratado apresenta, nas injunções morais e religiosas, certo charme. A série de orações descreve pequenos desenhos do quotidiano, tão vívidos quanto as ilustrações em um manuscrito iluminado.

Na ilustração da glutona:

Deus nos manda ir à igreja e acordar cedo e a glutona diz, 'eu preciso dormir. Eu estava bêbada ontem. A igreja não é uma lebre, ela esperará por mim'. Quando ela levantou com alguma dificuldade, você sabe que horas eram? Suas orações matinais são: 'Há! O que podemos beber? Não sobrou nada de ontem à noite? Então ela diz suas louvações desta maneira: 'Há! Nós bebemos bom vinho ontem'. Em seguida ela diz suas orações assim: 'Minha cabeça dói; eu não ficarei bem até beber algo'.

A primeira seção trata ainda dos deveres da esposa para com o marido e contém uma série de histórias, para ilustrar as injunções e fixá-las na memória. Dois exemplos provêm de leitura (ele conta que possui muitos livros em francês), copiados por ele de livros de sua propriedade. Um deles é a história da paciente Griselda, originariamente contada por Boccaccio (1313-1375 d.C.) e parafraseada em latim por Petrarca (13041374), cuja versão foi muitas vezes traduzida para o francês e uma vez para o inglês por Chaucer (1343-1400 d.C.), o Clerks Tale. O segundo é o Conto de Melibeus e Prudence, por Albertano de Brescia, que foi traduzido para o francês por Renault de Louens, cuja versão foi copiada e adaptada por Jean de Meung no Romain de la Rose. Entre as outras histórias reconta algumas retiradas da Bíblia e da Apocrypha, do famoso

\footnotetext{
${ }^{328}$ POWER, Eileen. The Goodman of Paris: a treatise on moral and domestic economy by a citizen of Paris, c. 1393. New York: Boydell Press, 2008.
} 
romance de The Seven Sages of Rome (As Sete Sábias de Roma), Game of Chess Moralised, de Jacques de Cessoles, e outras fontes. Há ainda exemplos oriundos da própria experiência: o cão fiel, que ele viu sobre a sepultura de seu dono em Niort, a esposa obediente que Sire d'Andresel perdeu numa aposta, a história da burguesa que deu sua honra para salvar a vida de seu esposo e a história da esposa que cuidou do filho bastardo de seu marido.

A segunda seção do Ménagier, na qual se passa da teoria para a prática e da alma para o corpo, é singular ${ }^{329}$ por se tratar do mais exaustivo tratado sobre administração doméstica da Idade Média que chegou até nós. Tem início com uma dissertação muito geral sobre diligência e prudência na forma de um longo poema, escrito em 1342 por Jean Bruyant, um escrivão do Châtelet, e chamado The Way of Peverty and Wealth (O Caminho da Pobreza e da Riqueza), copiado integralmente.

A seção compreende um pequeno tratado sobre jardinagem, cuidadosas instruções para a contratação e o tratamento dos criados, uma incursão sobre as qualidades e as doenças dos cavalos, e dois longos artigos sobre a compra de alimentos, o planejamento de festas e a escolha dos menus, finalizando com um livro de receitas muito bem elaborado e detalhado. Esta seção, tomada com algumas partes dos conselhos sobre como deixar um marido confortável da seção anterior, proporciona um incomparável quadro da vida doméstica da rica burguesia no século XIV.

$\mathrm{O}$ autor parecia possuir uma grande propriedade e conduzia uma casa de campo tão bem quanto uma casa na cidade, porque menciona várias vezes a necessidade de supervisionar as terras do campo 'quando está na cidade', e os animais do campo, que estavam aos cuidados do pastor Robin, o boiadeiro Josson, o vaqueiro Arnoul, a ordenhadeira Jehanneton e Eudeline, a mulher do fazendeiro, que toma conta das aves domésticas. Para ajudar na administração contam com o maître d'hotel chamado Master Jehan le Dispensier e com uma espécie de governanta, também acompanhante, Dame Agnes la Béguine.

Os criados são separados em três classes: aqueles contratados por dia ou por estação, para um trabalho especial, como carregadores ou transportadores, ceifeiros, separadores e fazedores de barris; os contratados por empreitada, como os alfaiates, peleiros, padeiros e sapateiros; e os criados domésticos ordinários, que eram admitidos

\footnotetext{
${ }^{329}$ Muitos tratados sobre o ideal de comportamento das mulheres foram escritos no período medieval e grande parte chegou até nós. Com relação a primeira seção do Ménagier, frise-se que tem muito em comum com o livro que o Knight of La Tour-Landry, seu contemporâneo, escreveu em homenagem a suas três filhas.
} 
para o ano inteiro e moravam na casa do dono. As instruções sobre como tomar conta dos criados contratados são práticas e apelam para benevolência e bom senso.

São apresentadas instruções relativas aos preços das vestimentas, usadas ano após ano, por toda a vida, e deixadas para a próxima geração. Há, ainda, instruções sobre como lavar vestidos e peles e preservá-los de traças, além de remover manchas de tinta e gordura. O Ménagier fornece sete receitas para remover estas últimas, mas é um pouco cético sobre uma ou duas delas.

Uma das regras do Ménagier para ter um esposo feliz é proporcionar-lhe um bom fogo no inverno e manter sua cama livre de pulgas no verão ${ }^{330}$. O autor apresenta seis receitas para aniquilar essas bestas familiares dos homens. E mais seis contra moscas e mosquitos. Além disso, oferece instruções de como tomar conta do vinho e conservar frutas e vegetais, como fazer hipocraz, como preparar água perfumada com sálvia, ou camomila, alecrim, manjerona, louros ou casca de laranja, com as quais lavar as mãos à mesa, como fazer vinho vermelho e branco, como conservar rosas no inverno, como manter pássaros em gaiolas e fazê-los reproduzir, como fazer tinta ou areia para ampulhetas, ou veneno para matar animais selvagens ou ratos, como curar uma dor de dente e a mordida de um animal raivoso.

A terceira seção pretendia apresentar três partes: uma de jogos de salão para diversão em casa, um tratado sobre caça com falcões e uma lista de adivinhações e jogos. Mas o livro não foi terminado. Os manuscritos conhecidos por Pichon contêm somente o tratado sobre caça com falcões, que está inserido depois do tratado sobre cavalos, na segunda seção, e não em sua posição apropriada, como indicado no plano inicial do autor.

\footnotetext{
${ }^{330}$ A principal impressão deixada por uma leitura desses palpites domésticos é a de que a vida caseira medieval estava vinculada a uma constante guerra contra as pulgas.
} 


\subsubsection{O burguês desconhecido e uma esposa}

\section{perfeita $^{331}$}

O autor que escreveu este tratado, entre 1392 e 1394, visando instruir sua jovem esposa, era um homem rico, instruído e com grande experiência em negócios, um membro da burguesia sobre a qual a monarquia francesa estava se apoiando com crescente confiança. Havia trabalhado na França e em Flandres e falava de alguns grandes homens daquela época como alguém que os conhecia pessoalmente: Jean Sire d'Andresel, com quem ele esteve em Niort, Bureau de La Rivière e, sobretudo, do famoso Duque de Berry. Parece provável que ele tivesse alguma ligação com os negócios do governo, acredita-se que em algum momento ele tenha sido empregado nas finanças militares, o que justificaria sua presença em Melun em 1358 e Niort em 1374, já que registrou que naquele período era um membro de algum corpo judiciário sediado em Paris e ligado ao governo da cidade.

Seu detalhado relato do jantar oferecido pelo Abade de Lagny para o procureur general e avocats $d u$ roi, e da festa de casamento de Jean Duchesne, procureur do Châtelet, parece corroborar a hipótese acima. Mas seu conhecimento literário e suas altas conexões demonstram ser mais provável que ele tivesse sido um oficial do que um mercador. Parece ter conservado, no entanto, a modéstia e senso comum dos burgueses orgulhosos de sua posição e que não desejavam deixá-la. Oferecia conselhos contra o comparecimento aos espetáculos dos lordes de alto nível, ou servir entremezes acima da cozinha de uma pessoa simples.

Le Ménagier de Paris fornece, ainda, um quadro da dona de casa medieval. A submissão ao marido só é igualada por sua habilidade em dar assistência e conforto ao esposo e arrumar sua casa.

Quando o burguês anônimo escreveu o Ménagier tinha pelo menos 60 anos e havia se casado recentemente com uma jovem órfã de uma província, muito mais nova que ele. Menciona sua enorme jovialidade, a necessidade de ajudá-la e direcioná-la na administração de sua casa. Há toques de ternura que são mais paternais do que maritais, um compassivo entendimento dos sentimentos de uma criança casada.

\footnotetext{
${ }^{331}$ POWER, Eileen. The Goodman of Paris: a treatise on moral and domestic economy by a citizen of Paris, c.1393. New York: Boydell Press, 2008.
} 
Os conselhos parecem carregados de melodiosa tristeza, como na expressão beleza e morte caminham de mãos dadas. Reconhecia ser função de sua esposa tornar confortável seu envelhecimento, mas tornar tal tarefa mais fácil seria função dele. Repete constantemente a garantia de que ele não exigiria dela excessivo respeito, ou um serviço demasiado humilhante ou pesado, que não lhe era devido. Desejava somente os cuidados e o serviço comum, ou menos.

Seu Prólogo dirigido à esposa fornece um charmoso quadro da cena que o levou a escrever o livro, relembrando-a como na semana de seu casamento ela havia implorado que não corrigisse seus erros na frente de estranhos, mas que dissesse o que fazia de errado quando estivessem sozinhos e assim ela se corrigiria. Ele assegura que tudo o que ela havia feito até então o agradara e ainda lhe agradaria.

Mas parece ter levado em consideração suas palavras e escreveu um pequeno tratado para mostrar-lhe como se comportar. Considerava difícil a situação de uma criança sem pai nem mãe, longe de parentes do sexo feminino, que poderiam aconselhála, tirada de seus costumes e de seu lugar de nascimento. Ele é velho, diz, e morrerá antes dela, que se casará outra vez. Isto resultará no descrédito dele aos olhos do segundo marido se ela não mostrar maneiras perfeitas e morais e totalmente competentes na condução da casa. Chega a escrever que você deveria amar seu esposo (eu ou outro) como Sarah, Rebecca e Rachel, e se refere constantemente a quem for seu esposo.

Sobre a postura da esposa perante o marido, as ideias são praticamente as mesmas dos outros homens de sua época. Elas podem ser resumidas a submissão, obediência e constante atenção. As esposas devem ser "saudáveis" na cama e na atividade, mesmo que isso esconda um coração pesado. Obediência e paciência são qualidades essenciais: quanto mais absurdas forem as demandas de seus maridos, mais devem ser obedecidas e não importa o quanto eles as importunem, elas nunca devem reclamar. Alguns exemplos do Ménagier foram inseridos para ilustrar a virtude da obediência. Em troca da obediência, o autor oferecia confiança e consideração, e a esposa que ele queria era prestativa e não uma escrava. A despeito da insistência sobre a obediência, que era uma característica desse período, o tom de suas observações contrasta muito favoravelmente com o de alguns escritores eclesiásticos ou aristocratas, que também produziram tratados didáticos sobre a orientação das mulheres. 
Aos olhos do autor, nenhuma mulher poderia ser uma esposa perfeita se não fosse também uma dona de casa perfeita e suas instruções para as donas de casa são a parte mais característica e valiosa de seu trabalho. 


\subsubsection{Carne, receitas e banquetes}

O tratado preocupa-se com a precisa organização de refeições, organização de pratos e sua apresentação. Não existe tal preocupação no Viandier, talvez por se tratar de um livro destinado a um profissional de cozinha altamente qualificado, para o qual seriam desnecessárias e supérfluas tais instruções. Além disso, apresenta dicas e técnicas de cozinha que vão do tratamento da carne ao uso de especiarias.

Quanto ao tratamento da carne, o Ménagier apresenta detalhadamente as técnicas que devem ser cuidadosamente observadas. Especifica que a matança do porco macho deve ocorrer em novembro e da fêmea, em dezembro. Descreve detalhadamente a preparação do chouriço. Explica que a carne de veado, ou outra carne, deve ser salgada no verão, em tina de água com sal grosso, e seca ao sol. Além disso, o quarto traseiro deveria ser salgado e cozido em vinho tinto, antes de ser cozido em água. Especifica, ainda, que as carnes de vaca e carneiro devem ser salgadas em junho ou julho, em peças, cozidas em água salgada e cebolinha desde a manhã até a noite, ou num dia inteiro, no máximo. Esclarece que a carne ao lado do pescoço do boi era considerada a melhor, e a localização do peito era indicada entre as pernas dianteiras, abaixo do ombro.

Menciona que a cabeça da vaca produz o melhor caldo de carne e que deve ser lavada duas vezes em água, depois fervida e a gordura bem retirada. Especifica que sempre se deve assar a carne com cravos e fritá-la com banha de porco. Determina que capões e galinhas devem ser sangrados na garganta e logo em seguida colocados para morrer em um recipiente com água muito fria, para que o sabor seja melhorado e para que pudessem ser conservados no ponto por até dois dias. Explica como diferenciar perdizes mortas há pouco tempo, que apresentam as penas fechadas e bem juntas da pele, bem arrumadas como as de um falcão, das que foram mortas há mais tempo e por isso têm penas desarrumadas que soltam facilmente da carne quando puxadas da barriga. Fornece receita para o veneno das flechas usadas na caça de veados e javalis e explica detalhadamente o processo de confecção de linguiças.

Segue a receita de como fazer linguiças:

Para fazer linguiças, quando você tiver matado seu porco. Pegue a carne das costelas e a melhor gordura, a mesma quantidade de uma e outra, quanto você quiser fazer e corte e pique bem pequeno com um cortador. Então esmague funcho e misture muito bem com um quarto se tanto de especiarias pó. Então 
misture com sua carne, suas especiarias e seu funcho e depois de tudo encha os intestinos, a saber, os menores ${ }^{332}$. (E saiba que os intestinos de um porco velho são melhores para isto do que os de um porco novo porque são maiores). E depois de tudo coloque-os na fumaça por quatro dias ou mais e quando você quiser comê-las, coloque em água quente e ferva uma vez e então coloque na grelha.

Podemos supor que certamente os cozinheiros de uma cozinha principesca sabiam exatamente como fazer linguiças e por isso essa receita não consta no Viandier. Essa hipótese é mais provável do que a de que não se realizava tal procedimento em cozinhas de grandes senhores, mesmo sabendo que era possível comprar linguiça de profissionais especializados, como foi mencionado no capítulo I.

Mais abaixo segue a receita do veneno para abater veados e javalis. No Viandier não existe preocupação em fornecer instruções de caça, uma vez que se trata de um livro voltado estritamente para o preparo de iguarias.

\begin{abstract}
Veneno para matar um veado macho ou um javali. Pegue a raiz de acônito, que possui flores azuis, e esmague num pilão e coloque em um saco ou um pedaço de tecido, e torça para obter seu suco; e coloque este suco numa bacia ao sol. E no cair da noite, deixe descoberto em um lugar seco sem água ou qualquer umidade. E continue colocando de volta no calor do sol até que se torne uma geleia rala como uma goma de cera, e coloque isto numa caixa bem fechada. E quando você for usá-la para caçar, besunte entre a extremidade da seta e o soquete de ferro, assim quando a fera for ferida isto entrará na carne. Porque se você fizer de outro modo, a saber, se você besuntar o ferro de outro modo, quando isto entrar na pele da fera, o ungüento permanecerá na pele, e o subterfúgio não vai funcionar
\end{abstract}

Embora o Ménagier só apresente uma receita de aves de caça (pegas, corvos e gralhas), aves que não constam no Viandier, não se pode concluir que, por se tratar de um tratado voltado para a burguesia, a caça tenha sido suprimida, já que não só aparecem receitas de veado e javali, como essa receita fornece especificamente instruções de como abater tais animais.

Assim, segue a receita para pegas, corvos e gralhas:

PEGAS, CORVOS, GRALHAS. Estas são mortas com setas de besta, as quais são cegas. E com bestas fracas você pode atirar nesses corvos que estão nos galhos, mas aqueles que estão em seus ninhos precisam ser alvejados com flechas mais fortes para trazer para baixo com os ninhos e tudo. Eles devem ser depenados, então aferventados com toucinho e cortados em pedaços e fritos com ovos, como carne picada ${ }^{333}$.

\footnotetext{
${ }^{332}$ Intestino delgado.

${ }^{333} \mathrm{O}$ chamado charpie, um prato de carne picada, era comum no período e seu preparo era conhecido.
} 
O Viandier não apresenta receita alguma para o preparo dessas aves. Por outro lado, o Ménagier não contempla uma sequer das inúmeras receitas de aves de caça que o Viandier propõe. No entanto, é possível encontrar aves de caça em alguns dos cardápios sugeridos no Ménagier, mesmo que tais receitas não estejam entre as oferecidas pelo autor, como se pode observar abaixo:

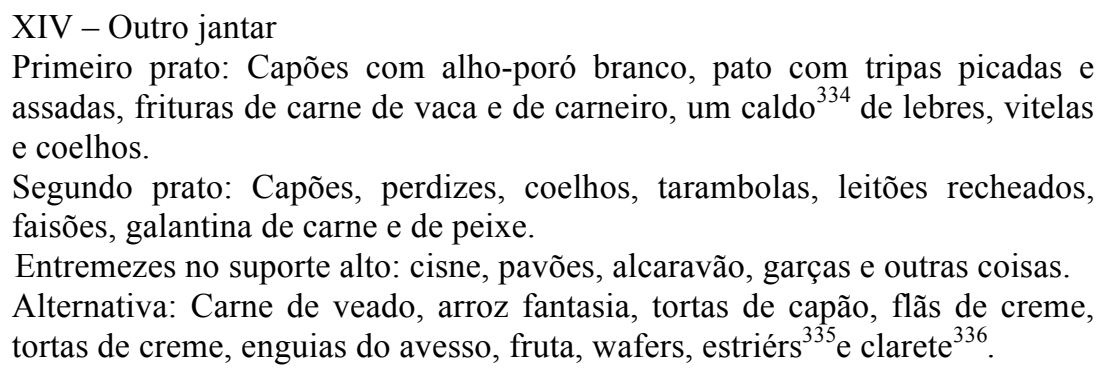

O autor do livro fornece, ainda, algumas dicas de criação de aves domésticas e caça de aves selvagens: dicas de como poderiam ser criados patos selvagens a partir dos anteriormente caçados, e de como em Paris os cozinheiros de alimentos assados engordavam seus gansos com uma massa grossa de farinha e água. E ainda de como deveriam ser tratados pássaros em um aviário.

Além de instruir o leitor quanto ao fato de ser possível comprar "fiado" dos açougueiros de Paris, colocar na conta, o Ménagier detalha que todos os açougues de Paris, semanalmente, sem contar a casa do rei e da rainha e de outros lordes da França, vendiam 3.080 ovelhas, 514 bois, 306 bezerros e 600 porcos. Na Porte-de-Paris haveria 19 açougueiros e estimava-se que vendiam, semanalmente, todos juntos, na estação alta e na baixa, 1.900 ovelhas, 400 bois, 400 porcos e 200 bezerros; em Sainte-Geneviève, 500 ovelhas, 16 bois, 16 porcos e 6 bezerros; em Le Parvis, 80 ovelhas, 10 bois, 10 bezerros e 8 porcos. Em Saint-Germain, haveria 13 açougueiros vendendo 200 ovelhas, 30 bois, 30 bezerros e 50 porcos. No Temple, 2 açougueiros vendendo 200 ovelhas, 24 bois, 28 bezerros, 32 porcos. E em Saint-Martin, 250 ovelhas, 32 bois, 32 bezerros e 22 porcos.

O Menagiér relata um consumo semanal de carne na casa do rei de ao menos 120 ovelhas, 16 bois, 16 bezerros e 12 porcos; e 200 carnes de porco salgadas por ano. Quanto às aves, 600 galinhas, 200 pares de pombos, 50 frangos e 50 filhotes de ganso.

\footnotetext{
${ }^{334} \mathrm{O}$ caldo Georgié é um caldo que, por definição, apresenta sempre um tom alaranjado, conforme o $\mathrm{Du}$ fait de cuisine - de Chiquart, 1420, registrado pelo escriturário Jehan de Dudens.

${ }_{335}^{335}$ Estrié é um tipo de massa de farinha, vinho branco, gemas de ovos e açúcar.

${ }^{336}$ Vinho com mel e especiarias.
} 
Especifica, ainda, que à rainha e às crianças da casa real destinavam-se semanalmente 80 ovelhas, 12 bezerros, 12 bois, 12 porcos e 120 carnes de porco salgadas por ano. Além de 300 galinhas, 36 frangos, 150 pares de pombos e 36 filhotes de ganso. Assim seria também nas casas de Berry.

Na casa do Duque de Berry aos domingos, e nas grandes festas, seriam sempre necessários 3 bois, 30 ovelhas, 460 dúzias de perdizes e coelhos. Embora tenha colocado tais quantidades em dúvida, pois não teriam sido fielmente verificadas. E para grandes festas, domingos e terças, e mais comumente nos outros dias, 2 bois e 20 ovelhas. Observa ainda que os valetes e pajens dessa casa tinham direito às bochechas, mandíbulas, pescoço e focinho do boi.

O Ménagier oferece receitas de diversos elaborados entremezes, alguns constantes no Viandier, mas é cuidadoso ao observar, em pelo menos três casos, que tais pratos não eram para sua cozinha burguesa. Isso ocorre especificamente com três receitas constantes no Viandier:

FRANGOS RECHEADOS, COLORIDOS E GLACEADOS. Eles são primeiramente inflados e toda a carne removida. Então encher com outra carne, e colorir ou glacear como acima. Mas há muita coisa a fazer, não é trabalho para uma pessoa. Por isso deixo para lá.

OMBROS DE CARNEIRO (DES ESPAULES DE MOUTON), quia nichil est nisi pena et labor ${ }^{337}$.

OURIÇOS podem ser feitos de bucho de carneiro e é uma receita muito cara e muito trabalhosa e pouco honrosa e proveitosa, portanto nichil hic.

As três receitas acima constam no Viandier, todas elas na seção de receitas adicionais de $V A T$, posterior ao século XIV. Vale observar que a receita de aves recheadas aparece duas vezes em $V A T$, pois já consta na seção de entremezes presente nos quatro manuscritos analisados. Essa primeira receita, em duplicidade em VAT, e presente nos quatro manuscritos do Viandier, é também apresentada no Ménagier uma vez, no início da seção de receitas. Mas ao final da mesma seção, o autor se refere novamente à iguaria e alega que não fornecerá a receita, por ser trabalhosa demais. Podemos supor que o autor teve acesso a um manuscrito do Viandier anterior a $V A T$, no qual a receita também aparecia duas vezes. E que esse manuscrito, do qual não temos notícia, já apresentava algumas receitas constantes na seção adicional de VAT.

\footnotetext{
${ }^{337}$ E o mesmo a respeito dos ombros de carneiro, que não é nada mais que dor e trabalho.
} 
A tabela abaixo apresenta as receitas de pratos de carne do Viandier, anteriores ao século XV, que são apresentadas também no Ménagier:

Tabela 17 - Receitas de carne comuns ao Ménagier e ao Viandier (anteriores ao século XV)

\begin{tabular}{|c|c|c|c|c|c|c|c|c|}
\hline RECEITA & SEÇÃO & $\begin{array}{l}\text { MODO DE } \\
\text { PREPARO }\end{array}$ & $\begin{array}{l}\text { TIPO DE } \\
\text { CARNE }\end{array}$ & ESPÉCIE & \multicolumn{4}{|c|}{$\begin{array}{l}\text { CONSTANTE NOS } \\
\text { MANUSCRITOS }\end{array}$} \\
\hline Veadada de veado fresco & Sopas gordas & $\begin{array}{c}\text { cozido } \\
\text { empada }\end{array}$ & quadrúpede & veado & VAL & & MAZ & VAT \\
\hline Cretonada de ervilhas & Sopas gordas & cozido & ave & galinha & VAL & $\mathrm{BN}$ & MAZ & VAT \\
\hline Cretonada de favas & Sopas gordas & cozido & ave & galinha & & $\mathrm{BN}$ & MAZ & VAT \\
\hline Cuminade de aves & Sopas gordas & cozido & ave & & VAL & $\mathrm{BN}$ & MAZ & VAT \\
\hline Cuminade de amêndoas & Sopas gordas & cozido & ave & & VAL & $\mathrm{BN}$ & & VAT \\
\hline Caldo de canela & Sopas gordas & $\begin{array}{l}\text { cozido } \\
\text { cozido }\end{array}$ & $\begin{array}{c}\text { ave } \\
\text { quadrúpede } \\
\end{array}$ & & VAL & $\mathrm{BN}$ & MAZ & $\overline{\text { VAT }}$ \\
\hline Caldo georgié & Sopas gordas & cozido & ave & doméstica & VAL & $\mathrm{BN}$ & MAZ & VAT \\
\hline Caldo ruivo & Sopas gordas & $\begin{array}{l}\text { cozido } \\
\text { cozido }\end{array}$ & $\begin{array}{c}\text { quadrúpede } \\
\text { ave }\end{array}$ & & VAL & $\mathrm{BN}$ & MAZ & VAT \\
\hline Vísceras de porco & Sopas gordas & cozido & quadrúpede & porco & VAL & $\mathrm{BN}$ & MAZ & VAT \\
\hline Caldo branco de capões & Sopas gordas & cozido & ave & capão & VAL & $\mathrm{BN}$ & MAZ & VAT \\
\hline $\begin{array}{l}\text { Caldo alemão de coelhos } \\
\text { ou aves }\end{array}$ & Sopas gordas & $\begin{array}{l}\text { cozido } \\
\text { cozido } \\
\end{array}$ & $\begin{array}{c}\text { quadrúpede } \\
\text { ave }\end{array}$ & coelho & VAL & $\mathrm{BN}$ & MAZ & VAT \\
\hline Mexido de aves & Sopas gordas & cozido & ave & & $\mathrm{VAL}$ & $\mathrm{BN}$ & MAZ & VAT \\
\hline $\begin{array}{l}\text { Rápido caldo inglês } \\
\text { Caldo amarelo-verde }\end{array}$ & $\begin{array}{l}\text { Sopas gordas } \\
\text { Sopas gordas }\end{array}$ & $\begin{array}{l}\text { cozido } \\
\text { cozido } \\
\text { cozido }\end{array}$ & $\begin{array}{c}\text { quadrúpede } \\
\text { quadrúpede } \\
\text { ave }\end{array}$ & porco & $\begin{array}{l}\text { VAL } \\
\text { VAL }\end{array}$ & $\begin{array}{l}\mathrm{BN} \\
\mathrm{BN}\end{array}$ & $\begin{array}{l}\text { MAZ } \\
\text { MAZ }\end{array}$ & $\begin{array}{l}\text { VAT } \\
\text { VAT }\end{array}$ \\
\hline Guisado de lebres & Sopas gordas & cozido & quadrúpede & lebre & $\mathrm{VAL}$ & $\mathrm{BN}$ & MAZ & VAT \\
\hline Lebres assadas & Carnes Assadas & $\begin{array}{r}\text { assado } \\
\text { empada }\end{array}$ & $\begin{array}{l}\text { quadrúpede } \\
\text { quadrúpede }\end{array}$ & $\begin{array}{l}\text { lebre } \\
\text { lebre }\end{array}$ & VAL & $\mathrm{BN}$ & MAZ & VAT \\
\hline Atoleiro de javali fresco & Carnes Assadas & assado & quadrúpede & javali & VAL & $\mathrm{BN}$ & MAZ & VAT \\
\hline Cisnes & Carnes Assadas & assado & ave & cisne & $\mathrm{VAL}$ & $\mathrm{BN}$ & MAZ & VAT \\
\hline Leitão recheado & Carnes Assadas & assado & quadrúpede & leitão & $\mathrm{VAL}$ & $\mathrm{BN}$ & MAZ & VAT \\
\hline Falso grenon & Entremezes & $\begin{array}{l}\text { cozido } \\
\text { cozido }\end{array}$ & $\begin{array}{c}\text { ave } \\
\text { quadrúpede }\end{array}$ & $\begin{array}{c}\text { ave } \\
\text { doméstica } \\
\text { vitela }\end{array}$ & VAL & $\mathrm{BN}$ & MAZ & VAT \\
\hline Aves recheadas & Entremezes & assado & $\begin{array}{c}\text { ave } \\
\text { quadrúpede }\end{array}$ & $\begin{array}{c}\text { galinha } \\
\text { carneiro } \\
\text { vitela }\end{array}$ & VAL & $\mathrm{BN}$ & MAZ & VAT \\
\hline Geleia de carne & Entremezes & Cozido & quadrúpede & & VAL & $\mathrm{BN}$ & MAZ & VAT \\
\hline Sálvia fria & Entremezes & Cozido & ave & & $\mathrm{VAL}$ & $\mathrm{BN}$ & MAZ & VAT \\
\hline Caldo de frango & Pratos $\mathrm{p} /$ doentes & Cozido & ave & frango & VAL & $\mathrm{BN}$ & MAZ & VAT \\
\hline Manjar branco de capão & Pratos $\mathrm{p} /$ doentes & Cozido & ave & capão & VAL & $\mathrm{BN}$ & MAZ & VAT \\
\hline
\end{tabular}

É notável como o autor do Ménagier se preocupou mais com as receitas de cozidos constantes no Viandier, em comparação com as receitas de carnes assadas.

Em seguida, as receitas de pratos de carne do Viandier apresentadas na seção adicional de $V A T$, que são também mencionadas na seção de receitas Ménagier: 
Tabela 18 - Receitas de carne comuns ao Ménagier e ao VAT

\begin{tabular}{|l|c|c|c|c|c|}
\hline \multicolumn{1}{|c|}{ RECEITA } & SEÇÃO & $\begin{array}{c}\text { MODO DE } \\
\text { PREPARO }\end{array}$ & $\begin{array}{c}\text { TIPO DE } \\
\text { CARNE }\end{array}$ & ESPÉCIE & $\begin{array}{c}\text { CONSTANTE NOS } \\
\text { MANUSCRITOS }\end{array}$ \\
\hline Leite entremeado & Receitas Adicionais VAT & cozido & toucinho & porco & VAT \\
\hline Ladrilhado & Receitas Adicionais VAT & cozido & carne & carne & VAT \\
& & ave & peixe \\
& & cozido & peixe \\
& & cozido & peixe & peixe & \\
\hline Tortas nórdicas & Receitas Adicionais VAT & assado & carne & carne & VAT \\
\hline
\end{tabular}

A tabela seguinte apresenta as receitas de molhos para acompanhamento de carnes do Viandier, anteriores ao século XV, que são oferecidas também no Ménagier:

Tabela 19 - Receitas de molhos para carne comuns ao Ménagier e ao Viandier

\begin{tabular}{|c|c|c|c|c|c|}
\hline RECEITA & $\begin{array}{l}\text { MODO DE } \\
\text { PREPARO }\end{array}$ & \multicolumn{4}{|c|}{$\begin{array}{c}\text { CONSTANTE NOS } \\
\text { MANUSCRITOS }\end{array}$} \\
\hline Camelino & & VAL & $\mathrm{BN}$ & MAZ & VAT \\
\hline Camelino de alho & & VAL & $\mathrm{BN}$ & MAZ & VAT \\
\hline Alho branco & & & $\mathrm{BN}$ & & VAT \\
\hline Alho verde & & VAL & $\mathrm{BN}$ & MAZ & VAT \\
\hline Alho e arenque fresco & & VAL & $\mathrm{BN}$ & MAZ & VAT \\
\hline Molho verde & & VAL & $\mathrm{BN}$ & MAZ & VAT \\
\hline Molho para guardar peixe & & VAL & $\mathrm{BN}$ & MAZ & VAT \\
\hline Pimenta amarela & fervido & VAL & $\mathrm{BN}$ & MAZ & VAT \\
\hline Pimenta Negra & fervido & VAL & $\mathrm{BN}$ & MAZ & \\
\hline Molho jance de leite de vaca & fervido & VAL & $\mathrm{BN}$ & MAZ & \\
\hline Molho jance ao alho & fervido & VAL & $\mathrm{BN}$ & MAZ & \\
\hline Um poitevine & fervido & VAL & $\mathrm{BN}$ & MAZ & \\
\hline
\end{tabular}

Outro diferencial na comparação entre os dois tratados é que no Ménagier são apresentadas quinze opções de cardápios para jantar em dias de comer carne, três de ceia para dias de comer carne $\mathrm{e}^{338}$ e seis de jantar em dias de comer peixe. Todos esses cardápios incluem diversos pratos, o que sugere que se destinam a ocasiões festivas ou banquetes. Também são apresentados exemplos de banquetes $^{339}$, que são detalhadamente descritos, desde o preparo das mesas à apresentação dos cardápios e

\footnotetext{
${ }^{338} \mathrm{O}$ jantar é a refeição realizada no meio do dia, enquanto a ceia refere-se à refeição noturna.

${ }^{339}$ Almoço oferecido pelo Abade de Lagny ao Monsenhor de Paris, ao procurador e ao advogado do rei e ao restante do conselho (16 pessoas). Festa de casamento que o Mestre Helve teria dado numa terça-feira de maio (40 pessoas). Casamento Hautecourt no mês de Setembro ( 40 pessoas).
} 
pratos específicos, passando pela decoração e disposição das iguarias e serviços prestados aos participantes, assim como a posição dos principais participantes à mesa.

Do último exemplo desses banquetes, o Casamento Hautecourt, refeição oferecida a quarenta pessoas, são ainda listadas as quantidades necessárias de cada item mencionado no cardápio (incluindo utensílios de mesa e cozinha) e de quais profissionais podem ser obtidos, assim como o valor pago a cada profissional extra requisitado para trabalhar no evento (entre os quais um cozinheiro com seus ajudantes e carregadores $^{340}$ ). Da parte que diz respeito ao consumo de carne, temos a seguinte especificação:

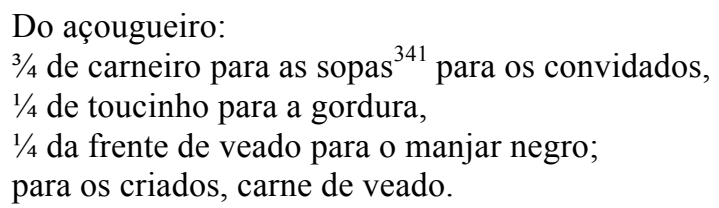

Seguem alguns exemplos de cardápios para o dia de comer carne, constantes no Ménagier. Cabe observar que alguns pratos que aparecem nesses cardápios não têm o respectivo modo de preparo oferecido pelo autor do Ménagier em sua seção de receitas.

\begin{abstract}
II - Outro jantar de vinte e quatro pratos em seis serviços
Primeiro serviço: Tortas de vitela com tutano, tortas de pequenas enguias, linguiças, canudos recheados e tortas norueguesas.

Segundo serviço: Ensopado de lebres e caldo de enguias, sopa de feijão, carne salgada, carnes assadas (vaca e carneiro).

Terceiro serviço: Capões, coelhos, carnes de vitela e perdizes, peixes do rio e do mar, taillis ${ }^{342}$ com carnes glaceadas.

Quarto serviço: Patos selvagens do rio com molho dodine, tenca com sopas e pastéis com molho picante, tortas de capão gordo com molho.

Quinto serviço: Um ensopado de carne, arroz fantasia ${ }^{343}$, enguias do avesso, peixes assados, crepes e açúcar.

O sexto e último serviço: Flãs açucarados e leite entremeado ${ }^{344}$, nozes, peras cozidas e confeitos. Hipocraz e wafer.
\end{abstract}

\title{
X - Outro jantar
}

Primeiro prato: Sopa de ervilha, arenques, enguias salgadas, ensopado de ostras, um caldo de amêndoa, um ladrilhado ${ }^{345}$, um caldo de lúcio e enguias, uma cretonada, um caldo verde de enguias, tortas prateadas.

\footnotetext{
${ }^{340}$ Casamento de Jehan Duchesne. Para o cozinheiro $4 \frac{1}{2}$ francos e ajudantes e carregadores 1 franco; ao todo $5 \frac{1}{2}$ francos.

${ }^{341}$ Pão ensopado.

${ }^{342}$ Viandier: O termo taillis (usado em BN, VAT e também no Ménagier) deriva de taillier (cortar), e refere-se a etapa final da receita. $V A L$ utiliza o termo garlins, de origem desconhecida.

${ }^{343} \mathrm{O}$ termo engoullé é derivado de goules, vermelho, produzindo a ideia de decoração, fantasia.

${ }^{344}$ Receita comum ao Viandier e Ménagier.

${ }^{345}$ Tuillé é uma receita comum ao Viandier e Ménagier.
} 
Segundo prato: Peixe do mar e peixe de água doce, tortas de sargo e salmão, enguias do avesso, um guisado de cebola e ervas, tenca com caldo de toucinho, um chouriço, crepes, alfaces, losangos ${ }^{346}$, orillettes ${ }^{347}$ e tortas norueguesas, lúcio recheado e salmão.

Terceiro prato. Frumento, carne de veado, pommeaulx glaceados, profiterole e castelos espanhóis ${ }^{348}$, um assado de peixe, galantina, lampreias, congros e rodovalho com molho verde, leite frito, tortas de creme e um grande entremez.

XVI - Ceia em quatro pratos

Primeiro prato: Ensopado, frango com ervas, caldo de agraço e aves domésticas, um ensopado ${ }^{349}$ de carne, lúcio pequeno e cadoz cozidos em água, leucisco e chastelongnes ${ }^{350}$ salgados.

Segundo prato: O melhor assado que puder ser feito de carne e peixe, petiscos de salsa e vinagre, galantina de peixe, peixe com molho branco e fígados de boi.

Terceiro prato: Tortas de capão, torta aberta de lúcio e enguias, alfaces, e um guisado de cebola e ervas, peixe, tubos receheados ${ }^{351}$.

Quarto prato: Galantina, lagostim, solha cozida na água, filhote de arenque e salvia fria, torta de miúdos com molho apimentado, tortas de carne de boi e torta de queijo ${ }^{352}$.

XVII - Outra ceia

Primeiro prato: Capões com ervas, uma cuminade, ervilhas, cadoz com molho amarelo, carne de veado com sopas.

Segundo prato: O melhor assado que puder ser feito, galantina, manjar branco festivo, flãs de creme bem açucarados.

Terceiro prato. Tortas de capão, salvas frias, ombro de carneiro recheado, lúcio pequeno à un rebouly ${ }^{353}$, carne de veado com molho de carne e vinho, lagostim.

${ }^{346}$ Massa doce com formato de diamante.

${ }^{347}$ Massa doce com formato de pequenas orelhas.

${ }^{348}$ Massa recheada na forma de castelo.

${ }^{349}$ Espinbesche é um ensopado com agraço, especiarias, molho camelino e salsa.

${ }^{350}$ Trata-se de um peixe, mas não foi possível encontrar a tradução exata.

${ }^{351}$ Pipesfarces, receita comum ao Viandier e Ménagier.

352 Talmouse.

${ }^{353}$ Tipo de molho fervido. 


\section{CONSIDERAÇÕES FINAIS}

O maior desafio desta análise foi buscar nas receitas do Viandier de Taillevent as hipóteses apontadas pela bibliografia e sustentá-las também com um estudo complementar do Ménagier de Paris e do Fabliau de Cocagne. Os tratados de alimentação da Idade Média, particularmente o Viandier, são vagos, pouco explicativos e apresentam versões diversas. Tentar atribuir sentido absoluto a este objeto de maneira isolada seria como acelerar na contramão de uma estrada. A carne está sempre presente. Mais que isso, ao lado do peixe é a protagonista indiscutível do tratado. Abordar seu simbolismo requer cuidado e comparação. Assim, os estudos sobre seu significado simbólico, realizados por Massimo Montanari, Bruno Laurioux, Terence Scully e demais historiadores da alimentação, apresentados na bibliografia, sustentaram esta dissertação.

Ao analisarmos o trabalho como um todo, percebemos que a principal característica do consumo de carne nos séculos XIII e XIV, na França, é a atribuição de valor suntuário, de posição social, de prestígio político a quem come e a quem oferece. No equilíbrio delicado entre os valores sociais, religiosos e dietéticos transparece o papel simbólico desse alimento. Com um material rico e conhecimento para analisá-lo, partimos das próprias receitas para chegarmos a conceituações que demonstrassem que suas apresentações e escolhas não eram aleatórias. Ao partirmos do concreto para o abstrato, essa pesquisa se baseou na tradução para o português, catalogação e apresentação das receitas que utilizavam carne e eram certamente anteriores ao século $\mathrm{XV}$, presentes em quatro versões do Viandier de Taillevent e sua comparação com as receitas similares e contemporâneas do Ménagier de Paris ${ }^{354}$.

No entanto, atribuir causa não é aspecto central deste trabalho. Le Viandier de Taillevent é um livro de receitas, um catálogo de informações, quase todas pouco verificáveis de fato. Mais que tudo, é uma enumeração de relatos e quanto mais teorizarmos sobre seus dados, em mais problemas e questões esbarraremos.

Os tratados culinários não são fontes a serem esnobadas. Neles podemos recolher quase todo o conteúdo como conhecimento possível, esmiuçá-lo, catalogá-lo,

\footnotetext{
${ }^{354}$ Para isso foi realizada a tradução para o português também das receitas e cardápios constantes no Ménagier de Paris.
} 
entendê-lo buscando algumas pistas e poucas confirmações. Mas não é possível criar relações causais ou engenharias reversas a partir de seu conteúdo unicamente. Os costumes que aparecem podem ser padrão, podem ser uma base para um conhecimento maior, e não mais que isso.

Como ressalta Nassim Nicholas Taleb ${ }^{355}$, com a história podemos vislumbrar o passado e ali encontrar o charme dos tempos antigos. Assim também, e talvez em especial, com a história da alimentação, principalmente quando estamos diante de um livro de receitas. Ali podemos encontrar a nossa própria narrativa, até mesmo de forma literária, que satisfaz o desejo da busca de identidade. Através desse tipo de documento nos são proporcionadas a emoção, a estranheza e a identificação, mas é muito importante o cuidado para que tais sentimentos sejam inofensivos. A história não deve teorizar sobre assuntos gerais e, menos ainda, podemos tomar conclusões e teorias gerais a partir de um tratado de cozinha. Podemos obter pistas, até mesmo uma confirmação negativa, como por exemplo, a ausência de receitas que utilizem carne de cavalo. Já a presença de molhos, temperos recomendados pela dietética, presentes nas receitas de carne e peixe do Viandier constitui pista na direção da confirmação de hipóteses levantadas pela bibliografia. A análise dessas informações tem muito valor, sempre com o necessário cuidado para não se deixar levar a uma ilusão de conhecimento. Olhando para o Viandier de Taillevent, pudemos conhecer o que constava num receituário utilizado nas cozinhas nobiliárquicas dos séculos XIII e XIV. A bibliografia e a documentação auxiliares nos forneceram direções, algumas confirmações e até mesmo algumas dúvidas. Mas teorizar com o que de fato podemos saber a partir da análise do tratado, de maneira isolada, é provavelmente chegar longe demais.

Buscar a certeza é um vício intelectual e não há julgamento possível a partir da ausência da evidência. No caso de um livro de receitas não existe certeza nem com a presença da evidência. Apenas com base na bibliografia pudemos nos conferir, sim, alguma arrogância epistêmica, ter uma inclinação a algumas hipóteses e conclusões, apresentadas e desenvolvidas ao longo deste trabalho. O Viandier parece seguir os preceitos dietéticos do período, imbuídos de ideias valorativas. Apresenta, sim, iguarias extravagantes. Preocupa-se com a apresentação de enorme repertório de receitas de

\footnotetext{
355 TALEB, Nassim Nicholas. A lógica do cisne negro: o impacto do altamente improvável. Tradução Marcelo Schild. Rio de Janeiro: Best Seller, 2007, p. 254.
} 
carne e receitas apropriadas à Quaresma (de peixe), enquanto a quantidade de receitas estritamente "vegetarianas" é mínima.

Muito foi visto e catalogado. Quase tudo passível de questionamento. O importante é mantermos claros os limites da informação que de fato esse documento pode oferecer e não cairmos na tentação de preencher lacunas. Essas lacunas podem eventualmente ser preenchidas, como demonstrado ao longo do trabalho, capítulo a capítulo, por outros documentos e outros estudos. Mas com base no Viandier de Taillevent, isoladamente, podemos dizer apenas que se consumia carne de caça e de criação, de aves e de quadrúpedes, e muito peixe, tudo quase sempre muito temperado. E se mesmo o que afirma claramente um tratado de culinária não pode ser tomado como uma verdade absoluta, isso não diminui o benefício que sua análise proporciona.

Quanto ao contexto histórico, procuramos evitar buscar qualquer tipo de analogia ingênua desse passado com o presente ou o futuro. $\mathrm{O}$ panorama do final da Idade Média é único, singular em suas marcantes tensões e representações, vê surgir novos grupos sociais e o questionamento de valores clericais e laicos. Entre o que se perde e o que se mantém equilibra-se o valor conferido ao luxo, ao raro, ao permanente e ao novo. O consumo demasiado de carne transforma-se sutilmente de atributo da nobreza guerreira em atestado de origem nobre e direito incontestável de um grupo socialmente superior. Tudo isso em um panorama de forte conotação religiosa, uma religião que condena o corpo e a carne, limita seu consumo, chegando a restringi-lo por quase metade do ano, o que faz despontar um alimento ainda mais luxuoso: o peixe.

Os sabores fortes da caça e o apetite voraz são símbolos alimentares do regime feudal. O combate ao excesso e à opulência viria a ser, séculos mais tarde, o combate dos iluminados contra velhas formas sociais, políticas e culturais. O século XVIII viu surgirem doutrinas vegetarianas, do alimento de paz, que proporciona a leveza necessária à liberdade da mente. Adam Smith escreveu em 1776 que a carne não é necessária à vida e que em nenhum lugar "a decência requer que um homem coma carne". Tais discussões e sistemas de valores só fazem sentido, evidentemente, nos meios que os viram nascer: a aristocracia e a alta burguesia ${ }^{356}$.

A Revolução Industrial alargou o mercado de alimentos e fez com que seus preços despencassem. Inovações tecnológicas modificaram o sistema de transporte e conservação da carne, permitindo a importação de lugares muito distantes a custo baixo.

\footnotetext{
356 MONTANARI, Massimo. A fome e a abundância: história da alimentação na Europa. Tradução Andréa Doré. Edusc: São Paulo, 2003, p. 195-212.
} 
Então, as razões do lucro se sobrepuseram às distinções e simbologias que destinavam tais alimentos a determinadas categorias sociais. Mas a distinção qualitativa permaneceu. Nos meios populares, entre operários e camponeses, a colocação de temas como a opção de alimentação vegetal não fazia o menor sentido. O século XIX, por sua vez, viu surgir as ondas e movimentos vegetarianos, o que aponta para uma difusão do consumo de carne que permitiu tal institucionalização.

Quanto esses novos contextos e conceitos foram influenciados pelos valores medievais, jamais saberemos com certeza, mas o consumo de carne parecia estar sempre imbuído de simbolismo, de valor positivo ou negativo. Sabemos que ela era frequentemente emblema de guerra e de riqueza, na contramão do pacifismo cristão, que ao mesmo tempo em que limitou seu consumo e aboliu seu caráter sagrado, aboliu também a possibilidade de sua conotação impura. Conflitantes ou não, são implicadas ideias no ato de comer carne, seja na Idade Média, na era Vitoriana ou ontem.

Mesmo assim, os Estados Unidos de hoje, por exemplo, mesmo apresentando um consumo de carne inquestionável, valorativo do indivíduo e tantas vezes irracional, não são geográfica, econômica ou socialmente comparáveis à Europa Medieval. Resvalar nesse tipo de questão é despencar na falácia narrativa.

Assim, nos últimos anos, pude me debruçar sobre um tema fascinante. Estudar uma paixão instintiva, inerente e natural, com a certeza de ter modificado minha concepção sobre o que é "comer" e "porque comer", da relevância cultural e simbólica das mais aparentemente simples escolhas. Com a isenção do olhar do pesquisador, concluí que os medievais conferiram valor simbólico ao que escolheram ou puderam comer. Um valor simbólico que acompanha cada passo da história da alimentação, em qualquer tempo, em qualquer lugar. 


\section{TRADUÇÃO}

\section{LE VIANDIER DE TAILLEVENT}

Esta tradução do Viandier é baseada principalmente na versão do manuscrito do Vaticano - VAT (a mais extensa), mas interpolada com variações das versões $V A L, B N e$ $M A Z$ (em itálico), para um resultado o mais completo possível.

Taillevent, mestre cozinheiro do Rei da França ensina aqui a toda gente como preparar uma refeição em cozinha de rei, duque, conde, marquês, barões, prelados e todos os outros senhores, burgueses, comerciantes e gentes de honra. ${ }^{357}$

Aqui começa o Viandier de Taillevent, mestre cozinheiro do Rei nosso senhor, para ordenar as viandas que seguem. ${ }^{358}$

Aqui começa o Viandier de Taillevent, mestre cozinheiro do Rei de França, onde estão contidas as coisas que seguem. ${ }^{359}$

Pour dessaler. Para dessalgar: Para remover o excesso de sal de qualquer tipo de sopa, sem adicionar ou remover nada ${ }^{360}$. Pegue um pano branco limpo e coloque na panela, girando frequentemente. A panela deverá estar fora do fogo.

Pour oster l'arsure. Para remover o gosto de queimado de uma sopa. Primeiro derrame a sopa numa outra panela, então ${ }^{361}$ pegue um pouco de levedura, amarre num pequeno pano limpo e coloque dentro da panela. Não deixe muito tempo.

Pource mesme. Para o mesmo: Pegue nozes e moa completamente, lave-as e ferva-as com a carne.

\section{Carnes fervidas}

Bouliture de grossechair. Fervura de carne gorda: Carnes gordas, como de vaca, porco e carneiro, fervidas, cozidas em água salgada e comidas em seguida. Carne de vaca, no verão, com molho de alho verde. No inverno, com molho de 
alho branco. Porco e carneiro também, se frescos, com um bom molho verde de salsa, hissopo e sálvia, feito sem vinho, e se salgados, com mostarda ${ }^{362}$.

Hericoc de mouton. Retalhado ${ }^{363}$ de carneiro: Envolver o carneiro cru em gordura de bacon e cortar em pedaços junto com cebola picada, numa panela tampada, mexendo frequentemente ${ }^{364}$. Umedecer com caldo de carne e vinho e acrescentar agraço ${ }^{365}$, macis ${ }^{366}$, hissopo, sálvia, pó fino de especiarias ${ }^{367} e$, opcionalmente, açafrão ${ }^{368}$. Ferver tudo junto. O pescoço, ombro e peito do carneiro são bons para este prato ${ }^{369}$.

Boulilardé. Carnes entremeadas ${ }^{370}$ e fervidas. Pegar a carne de animais domésticos ou selvagens e colocar para ferver em água e vinho, com macis e, opcionalmente, com açafrão.

Venoison de cerffraiche. Veadada de veado fresco: Aferventar e rechear seu interior completamente, ferver com trocas de água ${ }^{371}$, com macis e uma generosa quantidade de vinho. Cozinhar bem. Comer com molho camelino. Se numa empada: rechear a carne fervida com especiarias finas moidas ${ }^{372}$. Comer com molho camelino.

Sanglier. Javali: Veado ou javali selvagem fresco. Cozinhar em vinho e água e ferver outra vez. Comer com molho camelino ou molho de pimenta forte. Salgar o animal. Embeber a carne, lavar e descartar a primeira fervura. Lavar a carne em água fresca e deixar esfriar num pano. Então fatiar e ferver brevemente numa mistura de iguais partes de água e vinho. Cobrir a pele com castanhas torradas, colocar sobre um prato e regar com seu caldo ${ }^{373}$. Comer com molho de mostarda.

Chevreau sauvage ${ }^{374}$. Cabra selvagem: Preparar e comer ${ }^{375}$ do mesmo jeito que o veado acima. Se numa empada: ferver e rechear. Comer como acima. ${ }^{376}$

Chappons, veel, aux herbes. Capões com ervas, ou vitela com ervas. Colocar para cozinhar em água, bacon gordo, salsa, sálvia, hissopo, orégano, vinho e agraço. Açafrão e gengibre são opcionais.

\footnotetext{
${ }^{362}$ MAZ.

${ }^{363} \mathrm{O}$ hericoc (haricot) é um prato francês tradicional.

${ }^{364}$ MAZ.

${ }^{365} \mathrm{O}$ agraço é um suco de frutas ácido, feito em geral de uvas verdes ou maçãs, utilizado com função similar ao vinho ou vinagre. É muito menos usado hoje do que na Idade Média ou Moderna, embora não seja incomum na culinária da América do Sul. Pode ser encontrado, mais raramente, em mercearias da Europa e do Oriente Médio e, com facilidade, na Austrália, onde seu uso tornou-se comum, recentemente, em restaurantes do Sul do país.

${ }^{366}$ Macis é o arilo da noz moscada. Arilo é uma excrescência presente na superfície da semente.

${ }^{367} B N$.

${ }^{368} M A Z$.

${ }^{369}$ MAZ.

${ }^{370}$ São utilizadas carnes diversas, em geral de caça, consideradas mais secas, às quais se adiciona gordura.

${ }^{371}$ VAL e MAZ.

${ }^{372} M A Z$.

${ }^{373}$ VAL e $M A Z$.

${ }^{374}$ VAL, MAZ e BN.

${ }^{375}$ VAL E MAZ.

${ }^{376} B N$.
} 


\section{Sopas gordas ${ }^{377}$}

Chaudun de porc. Caldo quente de porco: Cozinhar a tripa do porco em água, cortar e fritar em gordura de bacon. Pegar gengibre, pimenta longa e açafrão e tostar embebidos em caldo de carne, porque o caldo da tripa cheira a esterco ${ }^{378}$, ou, alternativamente, em leite de vaca, e coar. Antes de servir, adicionar uma gema de ovo, agraço fervido e ferver.

Cretonnee de pois norveaulx. Cretonada ${ }^{379}$ de ervilhas frescas: Cozinhar as ervilhas completamente e fritar em gordura de bacon. Ferver leite de vaca, ou leite de amêndoas ${ }^{380}$, e embeber pão nele. Moer gengibre e açafrão, colocar no leite e ferver. Pegar galinhas cozidas em água, cortar em pedaços, fritar e colocar para ferver com a outra mistura. Tirar do fogo, derramar uma grande quantidade de gemas de ovo e servir.

Cretonnee de fevesnouvelles. Cretonada de favas frescas: $\mathrm{O}$ mesmo procedimento acima, para as ervilhas.

Comminee de poullaille. Cuminade ${ }^{381}$ de aves: Cozinhar a ave em vinho e água, cortar e fritar em gordura de bacon. Umedecer um pão pequeno em seu caldo. Coar e colocar para ferver a carne. Adicionar bem pouco gengibre e cominho. Bater uma grande quantidade de gemas de ovo e colocar dentro da sopa quando ela já estiver fora do fogo, e ter cuidado para que não solidifique.

Comminee d'almandes. Cuminade de amêndoas: Cozinhar completamente a ave em água, cortar e besuntar com gordura de bacon. Moer as amêndoas, umedecê-las em seu caldo e colocá-las para ferver com a carne. Adicionar gengibre e cominho fervidos em vinho e agraço. Sempre liga-se espontaneamente.

Brouet de canelle. Caldo de canela: Cozinhar a ave em vinho ou água, ou cozinhar qualquer outra carne, cortar e saltear em gordura de bacon ${ }^{382}$. Moer com amêndoas secas e uma grande porção de canela, umedecer com caldo de carne, coar, e ferver bem, junto com a carne, colocando agraço durante a fervura. Adicionar gengibre em pó, cravos e grãos do paraíso ${ }^{383}$. Deve ficar espesso e forte.

Brouet georgié. Caldo georgié ${ }^{384}$ : Pegar qualquer ave doméstica e cortá-la. Fritar folhas de salsa e cebolas bem picadinhas em gordura de bacon, adicionar fígado de galinha e tostar. Mergulhar em vinho e caldo de carne e ferver tudo

\footnotetext{
377 Trata-se de sopas e ensopados destinados a dias de não interdição católica ao consumo de carne.

378 Apenas $V A L$ não faz essa menção.

${ }^{379} \mathrm{O}$ cretonnee (termo derivado de cremare- cremar) indica uma longa fritura de ervilhas ou favas, sempre necessária no preparo desse prato.

${ }^{380} \mathrm{BN}$

${ }^{381}$ A cuminade é sempre uma sopa que tem no cominho seu ingrediente principal.

${ }^{382}$ MAZ.

${ }^{383}$ Cardamomo ou grãos da guiné.

${ }^{384} \mathrm{O}$ caldo Georgié é um caldo que, por definição, apresenta sempre um tom alaranjado, conforme o $D u$ fait de cuisine - de Chiquart, 1420, registrado pelo escriturário Jehan de Dudens.
} 
junto. Adicionar gengibre em pó, cravos e açafrão fervidos em agraço. Seu caldo deve ficar marrom-esbranquiçado e espesso como um soringue ${ }^{385}$.

Brouet rousset. Caldo ruivo: Pegar qualquer carne, fatiar cebolas e folhas de salsa e fritar levemente em gordura de bacon. Moer pão e fígado em caldo de carne e vinho, e deixar ferver com a carne. Adicionar gengibre em pó, canela, cravos, grãos do paraíso, brotos de cássia, fervidos em agraço. Deverá ficar com cor rosada.

Haste menue de porc/ Une vinaigrete. Vísceras de porco ${ }^{386} / \mathrm{Um}$ vinagrete: Assar pedaços de vísceras de porco num espeto, mas não deixar torrar. Cortálos, fatiar cebolas e fritá-los ligeiramente, juntos, em gordura de porco, ou em qualquer outra gordura, numa panela sobre fogo baixo, mexendo frequentemente. Quando estiverem suficientemente fritos, adicionar caldo de carne e predominantemente vinho sobre a carne e ferver. Então moer gengibre, grãos do paraíso e um pouco de açafrão, mergulhar em vinagre e ferver tudo junto. Deve ficar ligado e marrom-avermelhado.

Gravé de menus oiseaulx. Molho de pássaros pequenos: Fritá-los totalmente em gordura de bacon. Umedecer uma torrada em caldo de carne, coar e colocar na carne. Adicionar gengibre em pó e canela, e um pouco de agraço, e ferver tudo junto. Deve ficar fino e não muito espesso.

Blanc brouet de chappons. Caldo branco de capões: São cozidos em vinho e água, partidos pelos membros e fritos em gordura de bacon. Moer amêndoas, a carne escura de seus capões e fígado de aves ${ }^{387}$. Embeber no seu caldo e ferver isto com a carne. Moer gengibre, canela, cravos, galanga, pimenta longa e grãos do paraíso, e ferver tudo junto, completamente. Adicionar gemas de ovos bem batidas e coadas. Deve ficar bem espesso.

Boussac de lievres, connins. Aferventado ${ }^{388}$ de lebres, coelhos: Selar em um espeto ou na grelha, cortar pelos membros e fritar em gordura de bacon. Mergulhar torrada queimada em caldo de carne e vinho, coar e ferver tudo junto. Adicionar gengibre em pó, canela, cravos e grãos do paraíso, mergulhados em agraço. Deve ficar marrom escuro e não muito fino.

Hondous de chappons. Aferventado ${ }^{389}$ de capões: Cozinhar em vinho e água, quebrar em pedaços pelos membros e envolver em gordura de bacon. Umedecer uma pequena torrada no seu caldo e ferver a carne nele. Moer gengibre, canela, cravos e grãos do paraíso, e ferver em agraço.

Brouet d'Alemagne de char de connins et de poullaille. Caldo alemão de coelhos ou aves: para dias de comer carne: Cortar a carne de coelho ou ave $e^{390} \mathrm{e}$

\footnotetext{
${ }^{385}$ Um soringue é um caldo espesso. O nome é inspirado da forma de cocção da carne, sossenguar (em catalão ou provençal). A carne previamente assada ou parboilizada é frita (sempre com cebolas) e, posteriormente, sempre fervida num caldo de especiarias.

${ }^{386} \mathrm{O}$ hastemenue é definido no Ménagier de Paris como um prato de vísceras.

${ }^{387} M A Z$.

${ }^{388}$ O nome boussac designa um molho fervido.

${ }^{389}$ O hondous é similar ao boussac em sua simplicidade, tratando-se de uma carne fervida em num molho magro de especiarias.

${ }^{390}$ MAZ.
} 
fritar com cebola picada em gordura de bacon. Moer uma grande quantidade de amêndoas e colocá-las em caldo de vinho e carne, pondo para ferver com a carne. Adicionar gengibre em pó, canela, cravos, grãos do paraíso, noz-moscada e uma pitada de açafrão, mergulhados em agraço. Deve ficar amarelado e fino.

Hochepot de poullaille. Mexido ${ }^{391}$ de aves: Quebrar a ave em pedaços pelos membros e fritar em gordura de bacon. Embeber uma pequena torrada queimada e fígado de galinha em caldo de vinho e carne e colocar a carne dentro para ferver. Adicionar gengibre em pó, canela e grãos do paraíso, mergulhados em agraço. Deve ficar claro- escuro, mas não excessivamente.

Soutil brouet d'Angleterre. Rápido caldo inglês: Moer juntos castanhas cozidas sem pele, gemas de ovos cozidas em vinho e um pequeno fígado de porco. Umedecer com um pouco de água quente e coar. Gengibre moído, canela, cravos, pimenta longa, grãos do paraíso, galanga, nardo ${ }^{392}$ e açafrão para colorir, e ferver tudo junto.

Brouet de verjus. Caldo de agraço: Cozinhar sua carne com bacon gordo, para dar sabor, numa mistura de vinho, água e agraço, de maneira que o sabor do agraço predomine. Moer gengibre e um pouco de pão umedecido no caldo ${ }^{393}$. Adicionar uma grande quantidade de gemas de ovos cruas e ferver. Então, quando a carne estiver salteada, cobri-la com isto.

Brouet vergay. Caldo amarelo-verde ${ }^{394}$ : Cozinhar qualquer carne em vinho, água e caldo de carne, com bacon gordo para dar sabor. A carne estará salteada. Moer gengibre, açafrão, salsa e, opcionalmente, um pouco de sálvia, gemas de ovo cruas e pão, e coar tudo isto umedecido com seu caldo e um pouco de agraço. Se desejar, um pouco de um bom queijo.

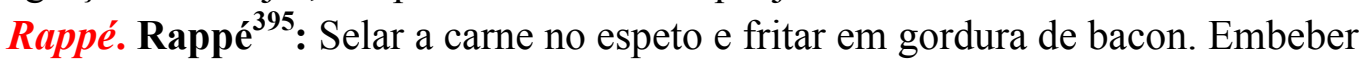
pão em caldo de carne, coar e verter sobre a carne. Moer gengibre, embeber em agraço e vinho, e verter sobre a carne. Pegar groselhas ou uvas ácidas fervidas em água ${ }^{396}$ e colocar a carne dentro (variação: usar como acompanhamento quando a carne é servida em tigelas) ${ }^{397}$.

Civé de veel. Guisado de vitela: Assar num espeto ou grelha, sem deixar queimar, cortar em peças e fritar em gordura com cebolas picadas. Mergulhar torrada queimada em caldo de vinho e carne ou em purê de ervilha, e ferver a carne com isto. Adicionar gengibre em pó, canela, cravos, grãos do paraíso e açafrão para colorir, mergulhados em agraço e vinagre. Deve ficar fino, e haver cebola suficiente. O pão deve estar escuro e cheio de vinagre e o ensopado deve ficar amarelado.

\footnotetext{
391 O termo francês hochepot aparece muito pouco nas receitas do período, embora seja uma receita bastante comum. Seu preparo é similar ao hardouil, com a diferença que a carne não é cozida antes da fritura.

${ }^{392} V A L$ e $M A Z$

${ }^{393} V A L$ e $B N$

${ }^{394}$ A cor designada por vergay resulta sempre de uma combinação de ingredientes verdes e amarelos, quase sempre salsa e açafrão.

${ }^{395}$ Rappé é um prato que leva molho de uvas frescas, ou apresenta uvas frescas em sua decoração.

${ }^{396}$ VAL.

${ }^{397} V A L$ e $M A Z$.
} 
Civé de lievres. Guisado de lebres: Deve ser preto e o pão bem queimado para dar cor. É feito dos mesmos ingredientes do guisado de vitela e a lebre não pode ser lavada.

Civé de connins. Ensopado de coelhos: Deve ser forte e nem tão escuro como o guisado de lebres, nem tão amarelo quanto o ensopado de vitela, mas entre os dois. Tem que ser feito com os mesmos ingredientes do ensopado de vitela.

\section{Aqui seguem carnes assadas}

Porc rosti. Porco assado: Comer com agraço. Algumas pessoas põem alho, cebolas, vinho e agraço na panela com o molho do assado e fazem um molho. Se numa empada, com açafrão e especiarias em pó ${ }^{398}$, comer com agraço.

Veel rosti. Vitela assada: Parbolizar ${ }^{399}$, entremear com gordura e assar. Comer com molho camelino. Se numa empada, com especiarias em pó, bacon gordo e açafrão. Comer com agraço.

Fraise de veel que len appele charpie. Tiras de bezerro chamado desfiado ${ }^{400}$ : Pegar a carne cozida, cortar em pedaços pequenos fritar em gordura de bacon. Moer gengibre e açafrão, misturar com ovos crus batidos e derramar sobre a carne na panela de fritura. Servir guarnecido com especiarias em pó ou agraço verde.

Mouton rosti. Carneiro assado: Comer com sal fino, com molho camelino ou com agraço.

Chevreaux, aigneaux. Cabras novas, cordeiros: Mergulhá-los brevemente em água fervente e secar um pouco no espeto. Colocar pequenos pedaços de gordura, antes de assar. Comer com molho camelino.

Oyes. Gansos: Depená-los a seco, mergulhar brevemente em água fervente e cortar as asas, pescoço e pés; assá-los sem colocar gordura ${ }^{401}$. Comer com molho de alho branco ou verde, com molho de pimenta preta ou jance. Algumas pessoas comem com molho saintmerry, que é com alho mergulhado no caldo de miúdos de ganso ou qualquer outra água gordurosa. Alguns gourmets levam o ganso ou gansinho, quando ele está assado, para os açougueiros de gansos de Saint Merry ou Saint Severin ou as portas de Gaudés, para serem cortados em pedaços e fatias de tal modo que em cada peça haja pele, carne e osso. Eles fazem isto muito asseadamente. (Variação: os miúdos devem ser lavados uma ou duas vezes em água salgada e colocados sobre o ganso - isto é, o fígado, cabeça, asas, pés e os outros miúdos. Tudo isto deve ser colocado para cozinhar em uma panela com sal e esfriar.Comer com vinagre e salsa antes do ganso

\footnotetext{
${ }^{398} V A L$.

${ }^{399}$ Ferver.

${ }^{400}$ Apenas VAT usa a designação charpie para esse prato. Charpie (gaze) é o nome usado duas vezes em Enseignements qui enseingnent a apareillier toutes manieres de viandes, XIV, para o processo no qual a vitela é cortada em tiras bem finas ou desfiada.

${ }^{401} M A Z$.
} 
estar assado porque esta é a primeira coisa a ser comida do ganso e é chamada "miúdos de ganso") 402 .

Poules rosties. Galinhas assadas: Devem ser depenadas em água, envolvidas em gordura e assadas ${ }^{403}$; comer com molho de sálvia frio, ou com molho camelino, ou com agraço ${ }^{404}$. Se em uma empada, com especiarias em pó e pedaços de bacon gordo $^{405}$. Comer com agraço verde no verão e sem molho no inverno.

Chappons, gelines, hetoudeaux. Capões, galinhas e galos: Capões assados, galinhas e galos. Comer com molho must no verão ou com molho poitevin ou jance no inverno. Este último molho é feito no inverno como o molho must, que é com vinho e açúcar fervidos juntos.

Connins rostis. Coelhos assados: Aferventar, entremear com gordura e assar. Comer com molho camelino. Se numa empada devem ser aferventados, entremeados com gordura e colocados inteiros ou em pedaços grandes na empada, com especiarias moídas. Comer com molho camelino ou com agraço.

Chappons de haulte gresse. Capões gordurosos em pasta: Sem untar. Encher de gordura o prato e fazer o molho dodine, sem utilizar essa gordura fervida numa panela de metal, com salsa, vinho e agraço. Fazers sopas ${ }^{406}$ grandes, delgadas ou pequenas, sem torrar.

Lievres em rost. Lebres assadas: Sem lavar, queimar num espeto, entremear com gordura ${ }^{407}$ e assar. Comer com molho camelino ou com molho saupicket, que é feito à parte, da gordura que cai na panela, cebola cortada, vinho, agraço e um pouco de vinagre. Colocar sobre a lebre quando ela estiver assada, ou servir separadamente em tigelas. E enquanto está assando, algumas pessoas regam com um molho, como o atolado de javali ${ }^{408}$. Se na empada, ferver grandes pedaços de lebre e cobrir de gordura. Comer com molho camelino ou polvilhados com especiarias em pó $^{409}$.

Bourbier de sanglier frez. Atoleiro ${ }^{410}$ de javali fresco: Colocar o peito primeiramente em água fervente e rapidamente retirar e colocar para assar num espeto. Regar com um molho feito de especiarias, isto é gengibre, canela, cravos e grãos do paraíso da maior variedade, torrados, mergulhados em vinho, agraço e vinagre e $\operatorname{coados}^{411}$. Quando estiver cozido, bater isto tudo junto (variação: quando estiver cozido, cortar em pedaços e colocar para ferver no seu $m o l h o^{412}$ ). Deve ser translúcido e escuro.

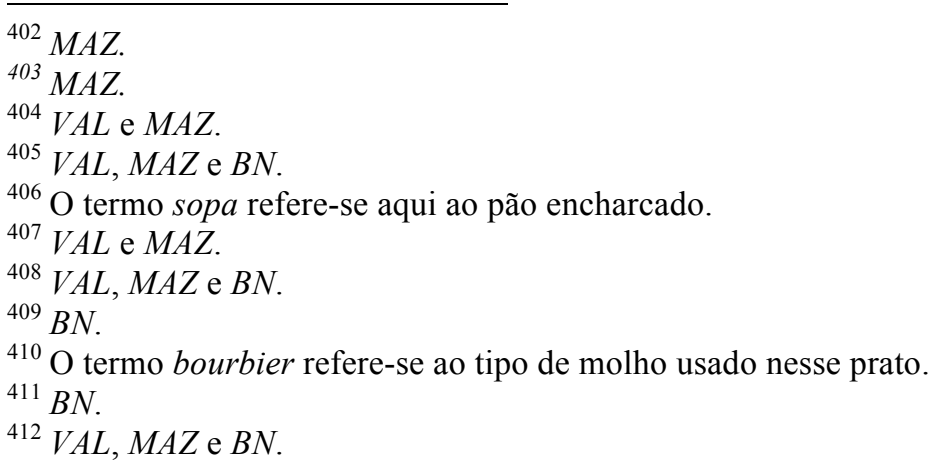


Toute venoison fresche. Todos os veados frescos: Note que $e^{413}$ veado fresco geralmente não é regado. Comer com molho camelino.

Pijons rostis. Pombas assadas: Assar com cabeças e sem os pés. Comer com sal fino. Se numa empada, comer com sal fino, ou vinho, ou cebolas, com a gordura da empada.

Menus oiseaux. Pássaros pequenos: Pássaros pequenos assados, como as cotovias, codornas, tordos e outros. Depenar a seco, sem água, remover as moelas e a víscera ${ }^{414}$, e fervê-las um pouco (variação: selá-las numa chama fraca $)^{415}$, e colocá-las num espeto com suas cabeças e pés, de lado e não longitudinalmente. Colocar entre cada duas delas pedaços ou fatias finas de bacon ou pedaços de salsinha e folhas de louro. Preencher as barrigas das aves com uma mistura de um bom e rico queijo com mocotó ${ }^{416}$. Comer com sal fino $e$ servir na mesa entre duas tigelas ou entre dois pratos $^{417}$. Se numa empada, com creme de queijo em suas barrigas.

Plouviers, videcoqs. Carambolas e galinholas: Depená-las a seco, selar, mantendo suas cabeças e pés, colocá-las longitudinalmente no espeto. Comer com sal fino e alguns preferem molho camelino. Se numa empada, com sal fino sem colocar queijo.

Perdris. Perdiz: Depená-las a seco, remover suas moelas ${ }^{418}$, cortar suas cabeças e pés, mergulhá-las em água fervente, tirar suas vísceras e lavá-las ${ }^{419}$, besuntálas com gordura (variação: besuntar seu interior com gordura) ${ }^{420}$. Comer com sal fino. Para alguns, numa empada, com sal fino. Outros as cortam e fatiam em pedaços pequenos e as colocam entre dois pratos com água e sal, colocam em fogo baixo até a água ferver, as comem e dizem que este é um molho muito bom.

Turturelles. Rolas: Depená-las a seco e mergulhá-las em água fervente sem besuntar de gordura. Comer com sal fino. Se numa empada, com a cabeça removida.

Cygnes. ${ }^{421}$ Cisnes: Depenar a seco, como um ganso, montar num espeto e assar com seus pés. Quando estiver sendo morto, sua garganta pode ser aberta da cabeça até os ombros. Opcionalmente pode ser glaceado ${ }^{422}$. Comer com molho de pimenta amarela.

Paons. Pavões: Matar como um ganso (variação: cisne) $^{423}$, dispensar a cabeça e o rabo, selar, colocar num espeto e glacear enquanto assa. Pode ser comido com sal fino. É melhor comido frio do que quente e pode ser conservado por muito

\footnotetext{
${ }^{413} M A Z$.

${ }^{414} M A Z$.

${ }^{415} V A L$ e $M A Z$.

${ }^{416}$ MAZ.

${ }^{417}$ MAZ

${ }^{418}$ VAL e $M A Z$

${ }^{419} V A L$ e $M A Z$

${ }^{420} V A L$ e $M A Z$.

${ }^{421} V A L$ e $M A S$ e $B N$.

${ }^{422}$ Com cobertura.

${ }^{423}$ MAZ.
} 
tempo $^{424}$. Fica bem por um mês depois de cozido, e se criar mofo em sua superfície, basta remover o mofo e encontrará a carne branca e boa. Pavão oferece três tipos de carne: uma similar à de vaca, outra similar à de lebre e uma terceira similar à de perdiz ${ }^{425}$.

Faisans. Faisões: Depená-los a seco, passar banha no interior e colocá-los num espeto. Opcionalmente mergulhá-los em água quente. O pássaro pode ser assado sem retirar sua cabeça ou rabo, que são envolvidos em panos úmidos para evitar que queimem. Alternativamente, remover a cabeça, rabo e asas e assar o pássaro sem besuntar, se ele for bom e gordo. Quando servir, recolocar a cabeça, o rabo e as asas nos respectivos lugares com palitos. Alternativamente, o pescoço e o rabo não devem ser assados ${ }^{426}$. Comer com sal fino.

Cigognes. Cegonhas: Podem ser depenadas como um ganso, mergulhadas em água fervente, sem as asas ${ }^{427}$. Os pés, rabo e cabeça permanecem. E podem ser colocadas para assar num espeto, chamuscadas completamente ${ }^{428}$. Comer com sal fino. $^{429}$

Herons. Garças-reais: Pode ser sangrada ou sua garganta cortada até os ombros, como foi feito com o cisne e o pavão, e pode ser preparada como a cegonha. Ou depenar a seco e mergulhar em água quente, tirando as asas, pés e cabeça (variação: deixar os pés e a cabeça), colocar num espeto $e$ chamuscar $^{430}$. Comer com sal fino ou molho camelino.

Malars de riviere. Pato-real do rio: Depená-los a seco, colocá-los num espeto sem a cabeça ou pés ou asas ${ }^{431}$, e pegar a gordura para fazer o molho dodine. Este é feito de leite ou vinho ou agraço, cebolas, salsa ${ }^{432}$, e especiarias em pó ${ }^{433}$. Derramar o dodine aos poucos sobre ele $e^{434}$ (ferver o pássaro esquartejado no dodine $e^{435}$ ). Deve ser comido com sal fino.

Outardes, gentes, grues. Abetardos, gansos selvagens e grous: Como com a cegonha. Comer com sal fino.

Butors. Alcaravões (bútios): Como com a cegonha. Comer com sal fino.

Cormorans. Cormorões: Como com a garça real. Comer com sal fino.

Poches et telles manieres d'oiseaulx de riviere. Colhereiros e aves similares do rio: Como a garça-real.

Sarcelle. Marrequinho: Exatamente como o pato-real do rio.

Pourcelet farci. Leitão recheado: Pode ser escaldado, bem lavado e posto num espeto. O recheio é feito com as vísceras do leitão, porco cozido, gemas de ovo

\footnotetext{
${ }^{424} M A Z$.

${ }^{425}$ MAZ

${ }^{426} M A Z$

${ }^{427}$ VAL.

${ }^{428} V A L$ e $M A Z$

${ }^{429} V A L, M A Z$ e $B N$.

${ }^{430}$ MAZ e $B N$.

${ }^{431} V A L$ e $M A Z$

${ }^{432} M A Z$

${ }^{433}$ VAL.

${ }^{434} M A Z$

${ }^{435}$ VAL.
} 
cozidas $^{436}$, um queijo rico cozido, castanhas sem pele e boas especiarias em pó (variação: $e s \mathrm{l}^{437}$ ). Tudo isto é moído junto $e^{438}$ posto na barriga do leitão, e o corte é costurado. Colocar para assar regando-o ${ }^{439}$ com vinagre e boa gordura fervida e sal. Comer com molho de pimenta amarela forte - algumas pessoas preguiçosas comem com molho camelino.

\section{Aqui seguem os entremezes}

Faux grenon. Falso grenon ${ }^{440}$ : Cozinhar fígados e moelas de aves domésticas, ou vitela, picar bem fino e fritar em gordura de bacon. Moer gengibre, canela, cravos e grãos do paraíso e ferver isto no vinho, agraço e caldo de carne e (variação: ou ) naquele caldo de fígado, moela e vitela. Adicionar uma grande quantidade de gemas de ovo, espalhar isto sobre a carne e ferver completamente tudo junto. Algumas pessoas adicionam um pequeno pão e um pouco de açafrão.Tem que ficar bem espesso, amarelado e carregado de agraço. Quando servir em tigelas, polvilhar canela em pó sobre o prato.

Menus drois. Delicado ${ }^{441}$ : Pés, fígados e moelas. Colocar para cozinhar inteiramente em vinho e água, e colocar num prato com salsa e vinagre sobre eles ou, em vez de salsa e vinagre, por sobre leite engrossado com gemas de ovo e pão, pimenta em pó e um pouco de açafrão. Servir em tigelas, sem salsa e vinagre $^{442}$.

Formentee. Frumento: Grãos limpos de trigo em água quente. Envolvê-los em um pano e bater fortemente com um pilão até toda a palha estar separada ${ }^{443}$. Lavar bem e cozinhar em água. Quando estiver cozido, misturar. Trazer leite de vaca para uma tigela, colocar o frumento nela e colocar isto na tigela outra vez, mexendo frequentemente ${ }^{444}$. Tirar do fogo, mexer frequentemente e adicionar uma grande quantidade de gemas de ovo bem batidas, que não podem estar quentes quando forem adicionadas ${ }^{445}$. Algumas pessoas adicionam especiarias e um pouco de açafrão e caldo de veado (variação: adicionar uma boa quantidade de açúcar na panela ${ }^{446}$ ). Deve ser amarelado e bem espesso.

Taillis. Fatias ${ }^{447}$ : Pegar figos, uvas, leite de amêndoas fervido, biscoitos, bolos e cascas de pão branco cortadas em pequenos cubos e ferver estes últimos itens no

\footnotetext{
${ }^{436} V A L$ e $B N$.

${ }^{437} V A L$ e $M A Z$.

${ }^{438} M A Z$.

${ }^{439} M A Z$ e $B N$.

${ }^{440} \mathrm{O}$ grenon é um patê condimentado, com pronunciado sabor de agraço, de cor amarela. Não era muito frequente sua apresentação como entremez.

441 VAL utiliza o termo mais adequado a esse prato: menudrois. O termo denota partes delicadas de animais. Trata-se de uma alternativa ao falso grenon.

$442 B N$.

${ }^{443} B N$

${ }^{444} V A L$ e $M A Z$.

${ }^{445} B N$.

${ }^{446} V A L$ e $M A Z$

${ }^{447} \mathrm{O}$ termo taillis (usado em BN, VAT e também no Ménagier) deriva de taillier (cortar), e refere-se a etapa final da receita. $V A L$ utiliza o termo garlins, de origem desconhecida.
} 
leite, com açafrão, para dar cor, e açúcar, e colocar tudo isto para ferver até ficar espesso o suficiente para fatiar. Servir em tigelas.

Millet. Milhete: Mergulhar o milhete em três trocas de água quente, colocar em leite de vaca morno - e não colocar a colher dentro até que tenha fervido. Retirar do fogo e bater com as costas da colher ${ }^{448}$, colocar um pouco de açafrão. Colocar para ferver o suficiente para ficar bem espesso. Servir em tigelas.

Poullaille farcie. Aves recheadas ${ }^{449}$ : Pegar galinhas, cortar seus pescoços, escaldá-las e depená-las.Ter cuidado para que a pele permaneça intacta e inteira, e não inflar as aves. Pegar algum tipo de canudo, empurrar entre a pele e a carne e soprar. Cortar a pele entre os ombros, não fazendo um buraco muito grande, e deixar as pernas com os pés, asas e pescoço, com a cabeça ainda presa pela pele. Para fazer o recheio, pegar carneiro, vitela, porco e a carne escura cozida ${ }^{450}$ das galinhas, picar tudo isto cru, e moer num pilão junto com uma grande quantidade de ovos crus, castanhas cozidas, um bom e rico queijo, boas especiarias em pó, um pouco de açafrão e sal para dar sabor. Rechear as galinhas e costurar o buraco outra vez. Com alguma sobra do recheio fazer bolas firmes usando uma grande quantidade de açafrão, do tamanho de pasteis, e cozinhá-las gentilmente em caldo de carne e água fervendo, assim elas não se desfarão. Montar as galinhas e as bolas em espetos de ferro fininhos.

Para glaceá-las ou cobri-las de verde e amarelo: para o amarelo, pegar uma grande quantidade de gemas de ovos, bater bem com um pouco de açafrão e colocar esse glacê em algum tipo de prato. E se quer um glacê verde, moer a verdura com os ovos sem açafrão ${ }^{451}$, coar e aplicar ${ }^{452}$ depois que suas aves e suas bolas de rechear estiverem cozidas.Colocar o espeto no prato com o glacê, duas ou três vezes. Colocar o glacê no espeto inteiro, por de novo no fogo o tempo que o glacê demandar. Cuidar para que o glacê não fique tão quente que queime.

[Sem nome $]^{453}$ Esquartejar galinhas e salteá-las numa panela com fatias finas de bacon, mexendo frequentemente e mantendo a panela tampada. Depois de fritar, pegar caldo de carne e cozinhar os pedaços nele. Adicionar gemas de ovos batidas, agraço e açafrão. Deve ficar bem espesso. Servir os pedaços em pratos. Em cada prato colocar uma fatia fina de bacon e colocar seu caldo por cima.

Gelle de poisson et de chair. Geleia de peixe ou carne: Pegar qualquer peixe cuja pele seja coberta com um óleo natural, ou qualquer carne $e^{454}$, e cozinhar no vinho, agraço e vinagre - algumas pessoas adicionam um pouco de água (variação: um pouco de pão ${ }^{455}$ ). Moer gengibre, canela, cravos, grãos do

\footnotetext{
${ }^{448} B N$.

${ }^{449} \mathrm{O}$ poulaillefarcie é entremez corriqueiro.

${ }^{450} M A Z$.

${ }^{451}$ VAL.

${ }^{452} V A L, M A Z$ e $B N$.

${ }^{453} M A Z$.

${ }^{454} M A Z$

${ }^{455}$ VAL.
} 
paraíso, pimenta longa, noz-moscada, açafrão ${ }^{456}$ e cerefólio ${ }^{457}$ e colocar no caldo. Coar(variação.:amarrar num pano limpo $^{458}$ ) e por para ferver com a a carne. Pegar folhas de louro, nardo da Índia, galanga e macis, apertá-los em seu pano de peneirar, sem lavá-lo, juntamente com o resíduo de outras especiarias, e colocar isto para ferver com a carne. Manter a panela fechada enquanto ela estiver no fogo e, quando estiver fora do fogo, continuar removendo a gordura até a preparação estar pronta para servir. Quando estiver cozida, coar seu caldo em um recipiente de madeira limpo e deixar descansar. Colocar a carne em um pano branco. Se for peixe, tirar a pele, limpar e por as peles no seu caldo até que tenha sido coado pela última vez. Esteja certo de que o caldo esteja claro e limpo e não espere que esfrie antes de retirar a gordura ${ }^{459}$. Servir sua carne em tigelas. E depois de tudo voltar o molho para o fogo num vasilhame limpo, e ferver mexendo constantemente. Colocá-lo fervendo sobre a carne. Sobre os pratos ou tigelas nos quais colocou a carne, espalhar buquês de cássia e raspas de macis, e colocá-los num lugar frio para servir. Qualquer um que faça geleia não pode cochilar. Se o caldo não estiver claro e limpo, filtrar em duas ou três camadas de um pano branco. E sal para dar sabor ${ }^{460}$. Por cima da carne colocar pescoço e pernas de caranguejo, cozido fechado, se for um prato de peixe.

Lamproie fresche a La saulce chaude. Lampreias frescas em molho apimentado: A lampreia pode ser sangrada pela sua boca e a língua é removida. Pode-se empurrar uma espada dentro dela para ajudar a sangria. Reservar o sangue porque ele é a gordura e raspar o interior da boca com uma faca ${ }^{461}$. Escaldar como faria com uma enguia e assar num espeto bem fino enfiado através das laterais uma vez ou duas. Moer gengibre, canela, cravos, grãos do paraíso, noz-moscada, uma pequena torrada mergulhada no sangue junto com vinagre e, se quiser, um pouco de vinho. Misturar tudo, levar a ferver e colocar a lampreia inteira dentro. O molho não pode ser muito escuro quando o molho é magro. Mas quando o molho é espesso e é chamado "lama", ele pode ser escuro. Também não é necessário ferver a lampreia com o molho. É melhor levar a lampreia seca para a mesa e o molho magro ou o molho "lama" ser despejado sobre a lampreia ou servido em tigelas. A lampreia pode ser cortada em pedaços longitudinais e mandada para a mesa em pratos. Alguns insistem em mantê-la seca com o molho gotejado e sal fino, servido no mesmo prato no qual foi trazida.

Lamproie a lagalantine. Lampreia à galantina ${ }^{462}$ : Sangrar a lampreia como anteriormente explicado, reservando o sangue. Por para cozinhar em vinagre,

\footnotetext{
${ }^{456} V A L, M A Z$ e $B N$.

${ }^{457} V A L$ e $M A Z$.

${ }^{458} V A L, M A Z$ e $B N$.

${ }^{459}$ VAL.

${ }^{460} B N$

461 VAL

${ }^{462}$ A galantina é uma iguaria típica da França e de Portugal. É preparada com uma variedade de carnes desossadas (misturadas ou não com frutas, vegetais, pão ralado e especiarias), cobertas com uma camada de geleia. Geralmente é consumida fria.
} 
vinho e um pouco de água. Quando estiver cozida, colocar para esfriar sobre um pano. Salpicar torrada no molho, coar e ferver com o sangue, mexendo para não deixar queimar. Quando estiver bem fervido, despejar num pilão ou em uma tigela de madeira limpa e continuar mexendo até esfriar. Moer gengibre, buquês de cássia, cravos, grãos do paraíso, noz moscada e pimenta longa, colocar no molho e colocar o peixe nele, numa tigela, como dito. Por igualmente em um vasilhame de madeira ou estanho e terá uma boa galantina.

Ris engoulé. Arroz fantasia ${ }^{463}$ : Selecionar o arroz, lavar totalmente em água quente e deixar secar no fogo. Cozinhar fervendo em leite de vaca. Adicionar açafrão em pó no leite, para dar-lhe uma cor castanho-avermelhada, e gordura do caldo de carne da panela.

Cigne revestu. Cisne revestido: Um entremez de cisne revestido de sua pele com toda a sua plumagem. Pegar o cisne e inflar entre seus ombros como as aves recheadas $^{464}$ e abrir sua barriga. Remover a pele junto, com o pescoço cortado na altura dos ombros, com as pernas permanecendo grudadas no corpo. Colocar o cisne num espeto entremeado como com aves ${ }^{465}$ e glacear. Quando estiver cozido, pode ser revestido com sua pele, com o pescoço de pé ou deitado. Deve ser comido com molho de pimenta amarela.

Froide sauge. Sálvia fria ${ }^{466}$ : Cozinhar a ave em água e deixar esfriar. Moer gengibre, buquês de cássia (variação.: canela $^{467}$ ), grãos do paraíso e cravos e não coar. Moer pão, salsa e sálvia com, se quiser, um pouco de açafrão nessa verdura para torná-la verde brilhante, e peneirar. Algumas pessoas adicionam gemas de ovos coadas, bem cozidas e mergulhadas em vinagre sem ferver ${ }^{468}$. Partir a ave em metades, quartos ou membros, colocar em pratos com o molho por cima e claras de ovos brancos bem cozidas por último ${ }^{469}$. Se usar ovos duros, cortá-los com uma faca em lugar de quebrá-los com as mãos.

Soux de pourcelet. Ensopado de leitão ${ }^{470}$ : Pegar os pés, rabo, orelhas e focinho do leitão e cozinhar com sal, vinho e água e $e^{471}$ proceder como na sálvia fria, mas sem usar açafrão ou ovos e com menos sálvia do que salsa. Logo que a carne esfriar, colocar o molho sobre ela ${ }^{472}$.

\section{Sopas espessas sem carne $\mathrm{c}^{473}$}

Comminne de poisson. Cuminade de peixe: Os peixes são cozidos em água ou fritos em óleo. Moer amêndoas e colocar em seu molho, em purê de ervilhas ou

\footnotetext{
${ }^{463}$ O termo engoullé é derivado de goules, vermelho, produzindo a ideia de decoração, fantasia.

${ }^{464} V A L$.

${ }^{465} V A L$.

${ }^{466} \mathrm{O}$ froidesauge é considerado um tipo de molho a ser servido com frango frio.

${ }^{467} M A Z$ e $B N$.

${ }^{468} V A L$ e $M A Z$.

469 VAL.

${ }^{470}$ Trata-se de um derivado do froidesouge.

${ }^{471} M A Z$.

${ }^{472} M A Z$

${ }^{473}$ Tratam-se de sopas e ensopados destinados a dias de interdição católica ao consumo de carne.
} 
em água fervida. Fazer um leite de amêndoas e deixar ferver ${ }^{474}$. Moer gengibre e cominho. Colocar em vinho e agraço, e por para ferver com seu leite. Se um prato para enfermo, é preciso colocar açúcar.

Brouet vergay d'anguilles. Caldo amarelo-verde de enguias ${ }^{475}$ : Tirar a pele ou escaldar as enguias. Cozinhar em vinho e água. Moer pão e salsa, com uma pequena quantidade de açafrão na verdura para torná-la verde amarelada, e molhar no molho. Moer gengibre, colocar em agraço, e ferver tudo junto. Se quiser, pequenos cubos de um bom queijo podem ser usados.

Gravé de loche. Molho de cadoz: Pegar torrada, vinho e purê de ervilhas ou água fervente, passar tudo no coador e por para ferver. Adicionar gengibre em pó, canela, cravos, grãos do paraíso e açafrão para colorir, colocados em vinagre e cebolas cortadas fritas no óleo. Ferver tudo junto. Fritar o cadoz em óleo sem passar na farinha e não ferver, mas colocar em tigelas com molho por cima. Antes de mais nada ele deve estar totalmente livre do óleo natural de sua pele $^{476}$. Deve ser de cor amarela.

Chaudumet à becquet. Chaudumet ${ }^{47}$ de lúcio $^{478}$ : Assar o peixe na grelha ${ }^{479}$. Moer pão, gengibre e açafrão e embeber em purê de ervilhas ou água fervida, vinho e agraço, coar e ferver. Despejar isto sobre o peixe e, se quiser, um pouquinho de vinagre. Deve ser de cor amarelada.

Une soringne. Um escaldado de enguia ${ }^{480}$ : Escaldar ou tirar a pele da enguia, fatiar e colocar para saltear em óleo numa panela coberta e em fogo baixo ${ }^{481}$, com cebola fatiada e folhas de salsa. Pegar torradas, purê de ervilhas ou água fervida e vinho - com o vinho predominando - coar e colocar junto para ferver. Adicionar gengibre em pó, canela, cravos, grãos do paraíso e açafrão para colorir, colocados em agraço. Ferver tudo isto. Temperar com vinagre.

Brouet sarrasinois. Caldo sarraceno: Tirar a pele das enguias, cortá-las e fritar os pedaços em óleo sem ter (variação: depois de ter) salpicado com sal. Moer gengibre, canela, cravos, grãos do paraíso, galanga ${ }^{482}$, pimenta longa e açafrão para colorir. Colocar isto no vinho e no agraço e ferver tudo junto com as enguias. Não deve ser muito espesso porque engrossa por si mesmo.

Lemprions. Filhote de lampreia: Escaldar e limpar totalmente, e fritar em óleo. Pegar um bom vinho adulterado e mostarda ou qualquer outro vinho vermelho com açúcar - embora com vinho adulterado doce seja desnecessário porque ele já é doce por natureza - e juntar gengibre e buquês de cássia em

${ }^{474}$ VAL, MAZ e $B N$.

${ }^{475} \mathrm{O}$ vergay de enguias é uma alternativa "magra" à receita 26.

${ }^{476}$ MAZ.

${ }^{477} \mathrm{O}$ chaudumet é um molho quente de peixe, agraço, pimenta e açafrão.

${ }^{478} \mathrm{O}$ becquet é um tipo pequeno de lúcio.

${ }^{479} B N$.

${ }^{480} \mathrm{O}$ nome soringue é derivado de sor, vermelho escuro. Consiste num prato de enguia frita, servido com um molho específico, escuro e espesso, com sabor característico de cebola, vinho e especiarias.

${ }^{481}$ VAL.

${ }^{482} V A L$ e $M A Z$. 
grande quantidade, peneirados juntos. Despejar isto sobre os filhotes de lampreia sem ferver ${ }^{483}$.

Civé d'oitres. Ensopado de ostras: Escaldar as ostras, lavar bem, cozinhar ligeiramente e fritar em óleo junto com cebolas picadas ${ }^{484}$. Pegar torradas, purê de ervilhas ou a água na qual as ostras foram escaldadas, ou qualquer outra água quente fervida, e uma generosa porção de vinho e agraço, e coar isto. Adicionar canela em pó, gengibre, cravos, grãos do paraíso e açafrão para dar cor, colocados em vinagre, e cebolas fritas em óleo. Ferver tudo isto junto. Deve ficar firme, amarelado e salgado para ter sabor ${ }^{485}$.

Soup en moustarde. Sopa de mostarda: Pegar o óleo no qual você fritou ou cozinhou seus ovos sem casca ${ }^{486}$, com vinho, água e cebolas cortadas fritas em óleo ${ }^{487}$. Ferver tudo numa panela de ferro. Pegar cascas de pão, torrá-las na grelha, cortá-las em pedaços quadrados e adicionar ao outro preparado para ferver. Coar seu caldo, escorrer sua sopa e despejar num prato (variação: tigela $^{488}$ ), por uma pitadinha de mostarda na panela de molho, ferver tudo e por em cima da sopa.

Civé d'oeufs. Ensopado de ovos: Escalfar ${ }^{489}$ ovos em óleo, fritar em óleo cebolas fatiadas e colocar ambos para ferver em vinho, agraço e vinagre. E quando servir seu caldo, esborrifar sobre sua carne. Não deve ser espesso. Faça a sopa de mostarda como acima.

Brouet d'Alemagne d'oueufs. Caldo de ovos da Alemanha: Ferver juntos ovos escaldados em óleo, leite de amêndoas fervido e fatias de cebola fritas em óleo. Moer gengibre, canela, cravos, grãos do paraíso e um pouco de açafrão colocados em agraço e adicionar isto aos outros ingredientes sem ferver muito. Deve ficar bem espesso e não muito amarelo. Com sopa de mostarda como acima, se quiser.

Lait de prouvance/ Laitlié. Leite provençal/ Leite ligado: Leite de vaca gorduroso. Leite de vaca deve ser colocado para ferver e retirado do fogo. Quando houver esfriado um pouco ${ }^{490}$, adicionar uma grande quantidade de gemas de ovos diretamente ou depois de terem sido coadas. Deve ser bem espesso e um pouco amarelado, porém não muito. Escalfar ovos em água e colocá-los com isto sem ferver.

Brouet vert d'ouefs et fromage. Caldo verde de ovos e de queijo: Pegar salsa e um pouco de sálvia com um pouquinho de açafrão nessa verdura e pão mergulhado em purê de ervilhas ou água fervida. Adicionar gengibre em pó colocado no vinho e por para ferver. Adicionar queijo e ovos escaldados em

\footnotetext{
${ }^{483} M A Z$.

${ }^{484} V A L$ e $M A Z$

${ }^{485} B N$

${ }^{486} B N$

${ }^{487} M A Z$ e $B N$.

${ }^{488} B N$.

489 Aqueça.

${ }^{490}$ VAL e $M A Z$.
} 
água. Deve ficar espesso e verde brilhante. Alguns não colocam pão, mas adicionam leite de amêndoas.

Une sauce jaunette de poison. Um molho amarelado de peixe: Lúcios pequenos ou percas têm a pele removida ${ }^{491}$ e são fritos em óleo sem passar na farinha. Moer amêndoas e colocá-las numa mistura de vinho e um pouco de agraço, coar e ferver. Adicionar no molho gengibre em pó, canela, cravos, grãos do paraíso e um pouco de açafrão e ferver tudo junto com açúcar. Deve ficar bem espesso.

Gravé de perche. Molho de perca: Perca ou qualquer outro peixe como cadoz, pode ser cozido, ter a pele retirada e ser frito sem farinha. O prato é preparado como o molho de cadoz. Não é tão amarelo, mas mais castanho-avermelhado e bem espesso.

\section{Pratos para os doentes. Infusões e outras coisas}

Couleis d'un poulet. Caldo ${ }^{492}$ de frango: Cozinhar o frango em água até desmanchar e moer com os ossos, num pilão. Mergulhar no seu caldo e peneirar. Se quiser, açúcar moído pode ser salpicado por cima. Deve ser absolutamente espesso.

Eaue rose d'un chappon ou poulle. Água rosada ${ }^{493}$ de capão ou frango: Colocar o frango ou capão secos numa panela de barro nova, glaceada e muito limpa, sem qualquer água e somente com um pouco de açafrão ${ }^{494}$, e cobrir a panela tão completamente que nada (variação: no vapor ${ }^{495}$ ) possa escapar. Colocar sua panela para ferver com água até o pescoço e cobrir de maneira que o vapor não possa escapar ${ }^{496}$ até que o capão esteja cozido. Remover o capão que, como dito, estava seco - e tirar da panela a água que exalou. Dar essa água que veio do capão ${ }^{497}$ para o inválido, porque dá sustança e o corpo inteiro é nutrido por ela.

Chaudeau flament. Caldo flamengo ${ }^{498}$ : Por um pouco de água para ferver, bater gemas de ovos, sem as claras, misturar com vinho branco e derramar gradualmente na água quando ela houver fervido e esfriado um pouco. Ferver outra vez ${ }^{499}$, cuidando para que não queime ${ }^{500}$, mexendo bem para manter o ponto. Adicionar sal quando estiver fora do fogo. Alguns adicionam um pouquinho de agraço.

\footnotetext{
491 VAL.

492 O couleis é uma receita recorrente no período, chamada colys ou coleys nos livros de culinária britânicos.

${ }^{493} \mathrm{O}$ rousse (termo utilizado em $V A L$ ), sugere uma tonalidade amarelo-acastanhado, e é substituído por rose, em $V A T$ e $B N$.

${ }^{494} V A L$ e $M A Z$.

$495 B N$.

${ }^{496} B N$.

$497 B N$.

${ }^{498}$ Trata-se de um prato comum a ser servido a pessoas doentes nos séculos XIV e XV.

${ }^{499} V A L$ e $M A Z$.

${ }^{500} M A Z$.
} 
Gruyau. Sopa de aveia: Não é descascada, prepare-a: colocá-la num pilão como trigo, cozinhar e esmagar. Colocar para ferver com leite de amêndoas, sal e açúcar. Alguns moem e coam. Não pode ser muito espesso.

Couleis de perche. Caldo de perca: Cozinhar a perca em água e reservar o caldo. Moer amêndoas e a perca juntos, adicionar ao caldo e por tudo para ferver. Coar e adicionar um pouco de açúcar. Deve ficar bem fino. Pode ser adicionado um pouco de vinho branco.

Blanc mengier d'un chappon. Manjar branco de capão: Cozinhar um capão em água até que esteja bem cozido. Moer uma grande quantidade de amêndoas junto com a carne escura do capão, derramar no seu caldo, coar tudo e por para ferver até ficar espesso o suficiente para fatiar. Despejar em uma tigela. Saltear meia dúzia de amêndoas descascadas e colocá-las no fim ou na metade de seu manjar. Na outra metade por sementes de romã com uma pitada de açúcar por cima de tudo.

Comminee de poisson. Cuminade de peixe: Ver na seção dedicada a Sopas de Carnes Gordas.

\section{Aqui segue sobre peixe de água doce}

Lux. Lúcio: Cozido na água, comer com molho verde, ou numa galantina feita como o bom molho camelino.

Brochet. Lúcio pequeno: Assado, comer com um chaudumet. Frito, numa sopa ou como está dito, em jance. Assado, comer com sal, vinho e especiarias em pó. Barbillons. Barbos: Cozidos em água, comer com molho de pimenta forte. Assados, comer com agracinho. Fritos, em molho de jance, como acima.

Bar. Robalo: Cozido em água, comer com molho verde.

Alose. Sável ${ }^{51}$ : Deve ser entremeado, salgado e cozido em água. Comer com molho de mostarda ou com cebolas e vinho, ou com molho verde. Assado, comer com molho camelino. Assado num forno, usando uma assadeira molhada, com um molho feito com vinho branco, agraço e especiarias em pó. E alguns não colocam nada além de molho camelino.

Carpe. Carpa: Cozida em água, comer com molho verde ou em galantina, como a lampreia.

Perche. Perca: Cozida em água e sem a pele, comer com vinagre e salsa, ou no caldo. Frita, numa sopa feita com caldo de carne.

Tanche. Tenca: Escaldada em água, cozida ${ }^{502}$, comer com molho verde. Frita, numa sopa. Assada, salpicada com pó de canela (variação: sal e pó fino de especiarias $^{503}$; costurar as duas bordas juntas com linha e assar o peixe na

\footnotetext{
${ }^{501}$ Apesar do sável ser um peixe marinho, é encontrado em rios e estuários na época de reprodução.

${ }^{502}$ MAZ.

${ }^{503} M A Z$
} 
grelh ${ }^{504}$ ), mergulhando no vinagre e salpicando com óleo de nozes ${ }^{505}$ (variação: oliva ${ }^{506}$ ) enquanto está assando ${ }^{507}$, comer com molho camelino.

Bresme. Sargo de água doce (ou brema) ${ }^{508}$ : Cozido em água ou assado ${ }^{509}$, comer com molho verde. Assado, comer com agraço. Se numa empada, salpicado com especiarias em pó, comer com sal fino. Deve ser cozido em água e vinho para ser comido com vinagre ${ }^{510}$.

Poulaille/ Baissaile/ Rossaille. Leucisco ${ }^{511}$ : Cozido em água, comer com molho verde (variação: molho de alho verde ${ }^{512}$ ). Assado, comer com agraço. Frito, comer com jance ou numa sopa como acima.

Anguilles. Enguias: Cozidas ${ }^{513}$ em água, comer com molho de alho verde. Assadas, comer com molho de alho branco ou alternativamente, com agraço ${ }^{514}$. De dentro para fora, com molho de pimenta como na lampreia. Se numa empada, salpicada com especiarias em pó, comer com molho de alho branco. E ocasionalmente numa sopa, como na seção de sopas acima.

Chevesnes. $\mathbf{C a b o z}^{515}$ : Cozido em água, comer com molho verde. Assado, comer com agraço $^{516}$.

Truite. Truta: Cozida ${ }^{517}$ em água, comer com molho camelino. Se numa empada, com sal fino e especiarias em po ${ }^{518}$.

Pinperneaulx. Pequenas enguias ${ }^{519}$ : Escaldadas, assadas, comer com agraço verde ou branco ${ }^{520}$.

Loche. Cadoz: Cozido ${ }^{521}$ em água. Primeiro, parcialmente cozinhar queijo, salsa e um pouco de vinho. Lavar e escaldar bem um cadoz e então ${ }^{522}$ colocá-lo para ferver com o queijo. Comer com molho de mostarda e servir com agraço ou groselhas cozidas em água ${ }^{523}$. Alguns colocam queijo. Frito, numa sopa, com queijo, enquanto estiver cozinhando.

\footnotetext{
${ }^{504} V A L$ e $M A Z$.

${ }^{505} V A L$

${ }^{506} M A Z$

${ }^{507}$ VAL e $M A Z$.

${ }^{508}$ O sargo é um peixe oceânico, mas o chamado sargo de água doce, ou brema, é um peixe encontrado em rios, lagos e canais.

${ }^{509}$ VAL e $M A Z$.

${ }^{510}$ MAZ.

${ }^{511}$ Os diferentes nomes atribuídos ao peixe dessa receita (nos diferentes manuscritos) parecem estar todos relacionados ao gênero leuciscus, peixes de água doce comuns no oeste da Europa.

${ }^{512} M A Z$.

${ }^{513} B N$.

${ }^{514} B N$.

${ }^{515}$ Designação mais comum na costa portuguesa, assim como alcabroz.

${ }^{516} V A L$ e $M A Z$

${ }^{517} V A L, M A Z$ e $B N$.

${ }^{518}$ VAL e $M A Z$.

519 Os pimperneaulx, segundo o Ménagier, diferem das enguias por não possuírem sua viscosidade característica, o que os torna inadequados ao preparo de gelatinas e galantinas.

${ }^{520} V A L$ e $M A Z$.

${ }^{521} V A L$ e $M A Z$

${ }^{522} V A L$ e $M A Z$

${ }^{523} V A L$ e $M A Z$
} 
Gaymeaux. Gaymeaux ${ }^{524}$ : Cozido $^{525}$ em água com cebola cortada, comer com molho de mostarda.

Meinuise. Alevinos ${ }^{526}$ : Em água com cebola cortada, comer com molho verde ou com um bom molho de alho.

Lamproions. Filhotes de lampreia: Cozidos em água ${ }^{527}$, ou fritos ${ }^{528}$, comer com molho de pimenta, como a lampreia, sem especiarias ${ }^{529}$ (variação: não muito espesso ${ }^{530}$ ) com sal fino ${ }^{531}$. Cozido ${ }^{532}$ em água, comer com molho de mostarda. Se numa empada, salpicado com especiarias em pó, com molho camelino na massa. Frito, comer com molho camelino ${ }^{533}$.

Santoilles. Lampreias pequenas ${ }^{\mathbf{5 3 4}}$ : Num caldo como uma sopa. Com molho camelino em empadas.

Ables. Alburno ${ }^{535}$ : Cozido $^{536}$ em água com salsa ${ }^{537}$, comer com molho de mostarda.

Escrevices. Lagostim: Cozido em água e vinho, comer com vinagre.

\section{Peixes de mar (oceano)}

Porc de mer. Golfinho: Abrir ao longo de suas costas, cozinhar em água e fatiar em pedaços, como o veado. Pegar vinho e o caldo do peixe, e moer gengibre, canela, cravos, grãos do paraíso, pimenta longa, e um pouco de açafrão e pão e fazer um bom caldo leve. Não deve ficar muito amarelo. Servir como entremez com (variação: por cima de ${ }^{538}$ ) um manjar branco.

Maquerel frais. Cavala fresca ${ }^{\mathbf{5 3 9}}$ : Limpar de suas guelras e assar na grelha. Comer com molho camelino ou com vinagre ${ }^{540}$ e especiarias em pó. Envolvê-la com uma rede para que não despedace ${ }^{541}$. Se numa empada, salpicada com especiarias em pó, comer com molho camelino ou com sal fino ${ }^{542}$. Se a cavala é salgada, cozinhar em água e comer com vinho e cebolinhas ou molho de mostarda.

\footnotetext{
${ }^{524}$ Não foi possível chegar a uma conclusão sobre a identificação desse peixe, embora seja mencionado especificamente em $V A L, B N, V A T$ e no Ménagier. ${ }^{525} B N$.

${ }^{526}$ Alevinos são peixes recém saídos do ovo.

${ }^{527} M A Z$ e $B N$.

${ }^{528} B N$.

${ }^{529}$ VAL.

${ }^{530} M A Z$

${ }^{531} V A L$.

${ }^{532} B N$.

${ }^{533} M A Z$

${ }^{534}$ A santoille é um tipo pequeno de lampreia de água doce.

${ }^{535} \mathrm{O}$ chamado ables ou bleaké provavelmente a espécie alburno comum ou prateado, um pequeno peixe de água doce.

${ }^{536} M A Z$ e $B N$.

${ }^{537} M A Z$

${ }^{538} M A Z$.

${ }^{539}$ A alternativa salgada é apresentada na mesma receita.

${ }^{540}$ MAZ

${ }^{541} B N$

${ }^{542} M A Z$ e $B N$.
} 
Gournault, rouget, grimondin. Robin ${ }^{543}$ do mar, salmonete, robin vermelho $^{544}$ : Limpar pela barriga e lavar cuidadosamente. Colocar na panela com sal sobre ele e água e cozinhar. Comer com molho camelino. E se quiser comê-lo assado, os ombros devem ser abertos ao longo das costas, deve ser lavado e colocado para assar. Regar frequentemente com agraço e salpicar especiarias em pó. Deve ser comido com agraço e vinagre ${ }^{545}$. Alternativamente, numa empada, com molho camelino.

Congre. Congro: Escaldar como uma enguia, cozinhar em água e sal como um salmonete. Alguns, quando está cozido, assam na grelha. Comer com molho verde ${ }^{546}$. Alternativamente, pode ser posto no forno.

Merluz. Merluza: Mergulhar em água por três $\operatorname{dias}^{547}$, lavar bem e fritar com farinha, em óleo. Comer com molho de alho de arraia. Alguns comem no próprio caldo, como o veado, com molho de mostarda.

Chien de mer. Cação: Limpar como um salmonete e cozinhar em água. Quando estiver cozido deve-se tirar sua pele (variação: preparado ${ }^{548}$ ) como uma arraia. Comer com molho de alho camelino (variação: molho de alho branco ou molho camelino $^{549}$ ).

Saumon frais. Salmão fresco: Deve ser entremeado para assar, deixando a espinha nele (variação: frito numa panela ${ }^{550}$ ). Então cortar em camadas e cozinhar em água e vinho, com sal. Deve ser comido com molho de pimenta amarela ou com molho camelino. Alguns deixam secar na grelha para comer. Alternativamente, numa empada, salpicado com especiarias em pó, comer com molho camelino. Se for salgado, pode ser cozido em água sem sal e comido com vinho e cebolas picadas.

Mulet. Tainha: Igual à cavala.

Morue fraiche. Bacalhau fresco: Preparar e cozinhar como um salmonete, com vinho enquanto cozinha. Comer com jance. Alguns colocam alho, outros, não. Comer com molho de mostarda ou com manteiga fresca derretida sobre ele.

Grapois. Carne de baleia: Fatiar crua e cozinhar em água, para ser servida, como porco, com ervilhas. Alguns a secam um pouco sobre o fogo. As ervilhas são melhores se colocadas no caldo.

\footnotetext{
${ }^{543} \mathrm{O}$ gunard é um termo onomatopaico para um peixe marinho de fundo, que ao ser apanhado emite um som semelhante ao coaxar de um sapo. É comparado ao robin por suas grandes nadadeiras, que se assemelham a asas de um pássaro em voo. Sua carne firme e suave é usada na culinária francesa, principalmente na bouillabaisse.

${ }^{544}$ A nomenclatura do grupo de peixes apresentados nessa receita varia nos manuscritos do Viandier e outros documentos, mas parece não haver dúvida quanto ao fato de serem considerados, no século XIV, os melhores representantes de peixes marinhos, pelo menos na culinária francesa.

${ }^{545} B N$.

${ }^{546}$ VAL, MAZ e BN.

${ }^{547}$ A preparação inicia-se com o dessalgar o peixe. Trata-se, portanto, de peixe salgado.

${ }^{548} B N$.

${ }^{549} B N$

${ }^{550} M A Z$.
} 
Moruaulx et egreffins. Bacalhau e hadoque: Podem ser preparados como bacalhau (variação: hadoque cozido como o salmonete ${ }^{551}$; quando frito, comer com jance $\left.{ }^{552}\right)$.

Orfin. Peixe-agulha: Limpar de suas guelras e assar. Comer com molho camelino.

Brete. Brecte ${ }^{553}$ : Cozinhar como uma arraia, como um salmonete ${ }^{554}$. Comer com molho camelino de alho ${ }^{555}$.

Colin. Escamudo ${ }^{556}$ : Como o bacalhau.

Truit saulmonoise. Truta salmonada ${ }^{557}$ : Cortar atravessado, cozinhar em água e vinho. Comer com molho camelino.

\section{Peixes de lago (mar fechado)}

Pleis. Solha: Limpar das guelras no sentido das costas, lavar bem e cozinhar como um salmonete. Comer com um molho de vinho e sal sobre ela ${ }^{558}$. Se desejar, numa sopa, cozinhar o peixe (variação: fritar $^{559}$ ) sem farinha.

Flais. Linguado: Preparado como solha, comer com molho verde.

Solles ${ }^{560}$. Solha ou linguado: Podem ser escaldados e limpos $^{561}$. Cozinhar e finalizar em água como a solha. Comer com molho verde num chaudumét ${ }^{562}$. Alternativamente, assar na grelha ${ }^{563}$ sem escaldar. Alguns tiram a pele das costas do peixe $e^{564}$. Comer com agraço. Frito em óleo, sem farinha ${ }^{565}$ e sem escaldar, comer com agraço.

Raie. Arraia: Limpar através do centro, deixando o fígado à parte. Cortar o peixe em peças e cozinhar como a solha. Tirar sua pele. Comer quente com molho camelino de alho. Alguns tostam pedaços do fígado da arraia e põem um creme de queijo muito espesso por cima. Este é um bom prato e muito apetitoso. Turbot. Pregado ${ }^{566}$ : Preparar e cozinhar como a solha. Retirar sua pele pelas costas. Pode ser em pedaços, comido com molho verde ou ensopado, com $\operatorname{agraço}^{567}$.

Barbue. Rodovalho ${ }^{568}$ : Preparado como o anterior. Se quiser, tirar a pele como na arraia. Comer com molho verde ou ensopado.

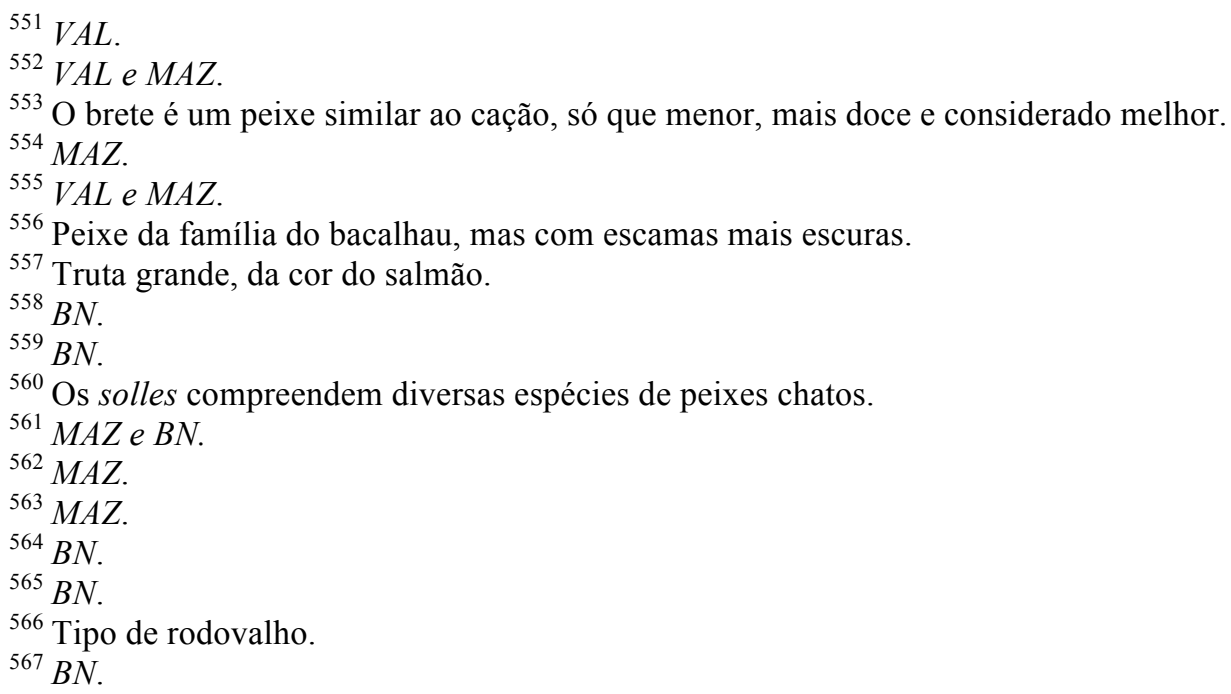


Bresme. Sargo: Escaldado e cozido em alho como o anterior, comer com molho camelino. Assado sem escaldar, comer com agraço. Se numa empada, escaldado, salpicado com especiarias em pó, comer com molho camelino.

Lymande. Solha-Escura-do-Mar-do-Norte ${ }^{569}$ : Preparado e cozido como a solha, comer com molho de vinho e sal. Ou fazer um molho de carne com ele.

Doree. Tilápia Saint Peter: Preparada e cozida em água como um pregado, comer com molho camelino. Assada, abrir longitudinalmente desde a cabeça, comer com agraço. Se numa empada, com especiarias em pó, comer com molho camelino.

Truitte saumonneresse. Truta salmonada ${ }^{570}$ : Deve-se tirar a pele, a cabeça e cozinhar em água ou assar. Comer com agraço.

Alose de mer. Sável ${ }^{571}$ : Como foi dito acima, entre os peixes do mar. Podem ser parboilizados e assados na grelha ou ainda assados num espeto sem parboilizar. São comidos com molho camelino ${ }^{572}$. São fritos como sável de água doce.

Ables/ Alles de mer. Anchovas: Cortadas em tiras, assadas, comer com molho de mostarda ou em molho de vinho.

Esperlans. Eperlanos ${ }^{573}$ : Colocar $\mathrm{em}^{574}$ uma empada. Retirar da empada, salpicar farinha e fritar em óleo. Comer com jance ou com molho verde de alho. Ou simplesmente frito, comer com molho de mostarda.

Esturjon. Esturjão: Escaldar o esturjão e cortar sua barriga ao comprido. Sua cabeça deve ser cortada e aberta ao meio e todos os outros pedaços podem ser cortados. Deve ser cozido em vinho e água, predominando o vinho. Então remover e deixar esfriar. Depois de tudo, cobrir com vinagre e salsa.

Seiche. Lula: Retirar a pele e partir em pedaços. Por tudo numa panela de ferro sem água ${ }^{575}$, com sal. Colocar no fogo para fritar, mexer e virar frequentemente até que fique bem clara. Colocar num pano e bater de leve até que esteja bem seca, passar farinha e fritar em óleo, com cebolas, que não devem ser postas na panela ao mesmo tempo em que os pedaços de lula porque poderão ficar muito marrons. Quando servir, salpicar especiarias em pó. Deve ser comida com molho de alho branco feito com vinagre. Pode também ser comida num caldo ou numa sopa ou com agraço ${ }^{576}$. Alguns passam na farinha.

Oestres. Ostras: Cozinhar em água e então fritar em óleo com cebolas. Comer ensopadas ou com especiarias em pó, ou com molho de alho.

\footnotetext{
${ }^{568}$ Turbot e barbue são peixes similares e preparados da mesma maneira.

${ }^{569}$ Peixe pequeno, similar ao linguado e à solha.

${ }^{570}$ A truta salmonada aparece também nas receitas de peixes de mar aberto (oceano).

${ }^{571} \mathrm{O}$ sável migra para água doce na época da desova, por isso figura também nessa categoria de peixes.

${ }^{572}$ VAL, MAZ e $B N$.

${ }^{573}$ Peixes semelhantes ao salmão.

${ }^{574}$ MAZ.

${ }^{575}$ MAZ

${ }^{576} V A L, M A Z, B N$.
} 
Hanons. Berbigões ${ }^{577}$ : Devem ser limpos de toda a sujeira, escaldados e lavados, salteados em óleo com cebolas cortadas e especiarias em pó. Comer com um bom molho de alho branco.

Moules. Mexilhões: Limpar de toda a sujeira e lavar de três a quatro vezes ${ }^{578}$. Cozinhar em água com vinagre (variação: vinho ${ }^{579}$ e água e $s a l^{580}$ ), hortelã (variação: salsa $^{581}$ ), se quiser. Servir com especiarias em pó. Alguns usam manteiga fresca $^{582}$. Comer com vinagre ou com agraço verde ou com molho de alho verde. $\mathrm{Ou}$, se desejar, um caldo pode ser feito com eles.

Escrevices de mer. Lagostas: Cozinhar em vinho e água, ou colocar no forno. Comer com vinagre.

Flans, tartes en Karesme. Pudins e tortas na Quaresma (que terão sabor de queijo $^{583}$ ): Pegar as ovas e o baço de ${ }^{584}$ lúcio e de carpa, amêndoas e moer tudo junto, juntamente com açafrão para adicionar um pouco de cor. Mergulhar isto em vinho branco. Preencher seus pudins ou tortas com açúcar ${ }^{585}$, o peixe desossado e a ova ${ }^{586}$. Quando estiver cozido, salpicar açúcar por cima. De um modo diferente: pegar enguias e remover suas cabeças, desprezando o rabo, e moer o restante com açafrão molhado em um pouco de vinho branco. Preencher seus pudins e polvilhar com açúcar quando estiverem cozidos ${ }^{587}$.

Poree de cresson. Purê de agrião: Pegar o seu agrião e ferver (variação: parboilizar $^{588}$ ) juntamente com um punhado de acelga. Cortar bem fino, saltear em óleo e colocar para ferver em leite de amêndoas ${ }^{589}$, se quiser. Em dias que não forem de jejum pode ser cozido em caldo de carne, ou manteiga ${ }^{590}$, ou com queijo acrescentado ${ }^{591}$, ou simples, sem colocar qualquer coisa nele, se gostar assim. Deve ser salgado para dar sabor ${ }^{592}$ e o agrião deve ser bem colhido ${ }^{593}$. É bom contra cálculos biliares.

D'autres menuz poitages. Outras sopas menores: Outras sopas menores, como acelga ensopada, repolho, nabo, alho poró, vitela em molho amarelo, e sopa simples de cebola, ervilhas, feijões, feijões amassados, feijões peneirados ou feijões em suas vagens, miúdos de porco, caldo de tripa de porco - mulheres são especialistas nisso e todo mundo sabe como fazê-las. Quanto às tripas, as quais

\footnotetext{
${ }^{577}$ Molusco marinho bivalve.

${ }^{578}$ VAL.

${ }^{579}$ VAL, MAZ e $B N$.

580 VAL \& $M A Z$.

${ }^{581} V A L$.

${ }^{582}$ MAZ.

${ }^{583}$ VAL e MAZ.

${ }^{584}$ VAL e MAZ.

${ }^{585} B N$.

${ }^{586} V A L$.

${ }^{587} B N$.

${ }^{588} B N$

${ }^{589} M A Z$ e $B N$.

${ }_{590} B N$.

${ }^{591} V A L$.

${ }^{592} M A Z$ e $B N$.

${ }^{593} B N$.
} 
não coloquei em meu livro de receitas, é de conhecimento comum como elas devem ser comidas.

\section{Molhos frios e como fazê-los}

Cameline. Camelino: Moer $^{594}$ gengibre, uma grande quantidade de canela, cravos, grãos do paraíso, macis e, se quiser, pimenta longa. Coar pão, que tem que ter sido mergulhado no vinagre. Coar tudo junto ${ }^{595}$ e por sal, se necessário.

Aulx camelins. Camelino de alho: Moer alho, canela e pão. Mergulhar isto em vinagre e agraço. Moer fígado de arraia com isto ${ }^{596}$.

Aulx blans. Alho branco: Moer alho e pão e mergulhar isto em agraço.

Aulx vers. Alho verde: Moer alho, pão e verduras e misturar isto com agraço.

Aulx a harens frais. Alho e arenque fresco: Moer alho com casca, mergulhar em mosto (variação: em vinho ${ }^{597}$ ) ou em agraço, juntamente com as cabeças dos arenques e servir com as cascas de alho.

[Sem nome: Molho de alho e amêndoas]: Moer alho sem casca, descascar amêndoas e colocá-las em agraço.

Saulce vert. Molho verde: Moer pão branco não tostado, uma grande quantidade de folhas de salsa com gengibre descascado e sálvia, colocar isto numa mistura de vinagre e um pouco de agraço e coar.

Saulce a garder poisson ${ }^{598}$. Molho para guardar o peixe: Moer pão, salsa, sálvia, erva benta, vinagre, gengibre, buquês de cássia (variação: canela), pimenta longa, cravos, grãos do paraíso, pó de açafrão e noz-moscada; mergulhar em vinho e agraço (variação: vinagre), coar e por no seu peixe. Deve ficar verde amarelado. Alguns colocam erva benta com raiz.

\section{Molhos Quentes (fervidos)}

La barbe Robert. Barba do Roberto, de outra maneira chamado Taillemaslee.

Poivre jaunet ${ }^{599}$. Pimenta amarela: Moer gengibre, pimenta longa, açafrão -e alguns adicionam cravos com (variação: um pouquinho de) agraço - e tostar. Derramar isto em vinagre (variação: agraço) e ferver quando a comida estiver para ser servida.

Poivre noir ${ }^{600}$. Pimenta negra: Moer gengibre, pimenta redonda e torrada queimada. Derramar em vinagre (variação: e um pouco de agraço) e ferver.

Sauce jance au lait de vache ${ }^{601}$. Molho jance ${ }^{602}$ de leite de vaca: Moer gengibre e gemas de ovo, derramá-los em leite de vaca e ferver.

\footnotetext{
${ }^{594} V A L, M A Z$ e $B N$.

${ }^{595} B N$.

${ }^{596}$ VAL e $M A Z$.

${ }^{597}$ MAZ.

${ }^{598} V A L, M A Z$ e $B N$.

${ }^{599} V A L, M A Z$ e $B N$.

${ }^{600} V A L, M A Z$ e $B N$.
} 
Sauce jance aux aul ${ }^{603}$. Molho jance ao alho: Moer gengibre, alho $e$ amêndoas, derramá-los em bom agraço e ferver. Por vinho branco (variação: se desejar).

Jance de gingembre ${ }^{604}$. Jance de gengibre: Moer gengibre e amêndoas, mas não alho, derramar em agraço e ferver. Alguns colocam vinho branco.

Une poitevine $^{605}$. Um poitevine ${ }^{606}$ : Moer gengibre, cravos, grãos do paraíso, torrada queimada e fígado de frango assado. Derramar em (variação: vinho e) agraço e ferver com a gordura do assado. Regar o assado com o molho e servir em tigelas.

Epices qui appartienent en cest present Viandier. Especiarias necessárias para este Viandier: Anotar: gengibre, canela, cravos, grãos do paraíso, pimenta longa, espicanardo, pimenta redonda, buquês de cássia, açafrão, noz moscada, folhas de louro, galanga, macis, folhas de louro, cominho, açúcar, amêndoas, alho, cebolas, chalotas e cebolinhas. O caminho para uma cor verde (ou para dar um sabor azedo): salsa, erva benta, vinagreira, folhas de videira e galhos da videira, groselhas e trigo verde no inverno. Para maceração: vinho branco, agraço, vinagre, água, caldo gorduroso, leite de vaca e leite de amêndoas.

\section{[Receitas adicionais $(M A Z)]^{607}$}

[Molho camelino de mostarda]: Pegar mostarda, vinho tinto, canela em pó e açúcar suficiente e deixar tudo macerando junto. Deve ser denso como canela. É bom para qualquer assado.

[Molho de manjerona]: Pegar suco de manjerona doce, iguais quantidades de água e vinho branco e adicionar gengibre e vinho branco, um pouco de cravo, canela e açúcar.

[Aves ensopadas]: Cozinhar completamente com carne bovina, deixando a medula de lado. Remover a carne e remover toda a gordura da panela. No molho magro que restar, cozinhar capões, frangos, pombos, perdizes e qualquer outra carne que quiser. Juntar com este cozido pimenta redonda, uvas passas e a medula. Coar pão branco com o caldo. Moer gengibre, canela,noz moscada e cravos, com uma grande quantidade de vinho branco e agraço. Adicionar açafrão e açúcar. Glacear sua ave inteira. Servir com o caldo por cima.

\footnotetext{
${ }^{601} V A L, M A Z$ e $B N$.

${ }^{602} V A L$ não usa a designação jance.

${ }^{603} V A L, M A Z$ e $B N$.

${ }^{604} B N$

${ }^{605} V A L, M A Z$ e $B N$.

${ }^{606}$ MAZ não usa a designação poitevine.

${ }^{607}$ Toda essa série de receitas pertence apenas ao manuscrito da Mazarine - MAZ.
} 
[Ensopado de carne de carneiro]: Pegar peças de carneiro e cozinhar em um pouco de água. Adicionar vinho, cebolas e salsa finamente cortadas, especiarias em pó fino, açafrão, agraço e um pouco de vinagre.

[Tortas de ervas, queijo e ovos]: Pegar salsa, hortelã, acelga, espinafre, alface, manjerona, manjericão, tomilho, e moer tudo junto num almofariz. Pingar água pura e espremer o suco. Adicionar gengibre em pó, canela e pimenta longa, um queijo de boa qualidade ralado e sal. Bater tudo junto. Fazer uma massa bem fina para colocar do lado de seu prato e alinhar seu prato com ela. Revestir a parte de dentro do prato com gordura de porco, colocar sua massa, colocar seu prato sobre os carvões e de novo cobrir a parte de dentro da massa com gordura de porco. Quando estiver derretido, por seu recheio na massa e cobrir com o outro prato. Por fogo em cima, assim como embaixo e deixar sua torta secar um pouco. Descobrir o topo do prato e colocar cinco gemas de ovos e especiarias moídas fino. Por cuidadosamente sobre a torta, então recolocar o prato como estava antes edeixar que cozinhe gradualmente em fogo baixo. Checar frequentemente para ver se não está passando do ponto de cozimento. Por açúcar sobre tudo quando for servir.

[Um manjar de ovo]: Pegar bolos brancos ou qualquer pão branco muito seco e grelhar. Por carne de boi ou de ave numa panela e deixar ferver sobre um fogo baixo de carvão. Adicionar açafrão, uma boa quantidade de queijo grelhado, pondo primeiro pão dentro do seu caldo quando este ferver. Ao servir, coar ovos, fazê-los tão espessos quanto arroz e guarnecer com queijo grelhado sobre os ovos.

[Frituras de salvia moscatel]: Pegar a erva chamada salvia moscatel, moer, mergulhar em água pura e bater com farinha bem peneirada. Adicionar algum mel e um pouco de vinho branco e bater isto junto até amaciar. Fritar pequenas colheradas dessa mistura em óleo, como é feito com frituras, e por alecrim generosamente em cada fritura. Espremer suas frituras entre duas lâminas para retirar o óleo e colocar numa nova panela fina ao lado do fogo. Envolvê-las num prato com açúcar.

\section{Aqui seguem alguns remédiose experimentos relativos a vinhos e outras coisas} $(V A T)^{608}$

Pour amender moust ou vin nouvel, ou pour faire vermeulx moust ou vin nouvel pour vendre tantost. Para melhorar mosto ou vinho novo, ou para torná-lo vermelho para uma venda inicial. Para um tonel de vinho, medida de Paris, pegar três pennyweight ${ }^{609}$ de açafrão em grão que tenha sido mergulhado no mosto. Para cada barril ferver uma panela com dois pennyweight cheios de

\footnotetext{
${ }^{608}$ Toda essa série de receitas pertence apenas ao manuscrito da Vaticana - VAT.

${ }^{609} 1$ pennyweight $=1.55517384 \mathrm{~g}=$ iii deniers.
} 
mel junto com uma panela com seis pennyweight de vinho, mexer bem e coar. Pegar uma tigela cheia de farinha de milho e misturar essas três coisas juntas. Deverá estar fino e bom para beber e vender brevemente.

Pour garder vin dlengresser et d'estre trouble. Para conservar o vinho evitando que fique viscoso e turvo: Por num barril de vinho uma tigela cheia de sementes de uva de vinho tinto que tenham sido secas e depois fervidas. Então pegar borras de vinho branco, secá-las, assá-las até que virem cinzas e colocar uma tigela cheia delas dentro de uma garrafa sem mexer.

Pour tour vins degresser. Para remover a grossura do vinho: Pegar uma tigela cheia de sementes de uva, secas e em grãos, somente de vinho tinto, uma tigela cheia de gordura da mesma cor do vinho, um pennyweight de fermento, meia libra de alumínio, dois gomos de gengibre, um pouco de borra queimada. Colocar todas estas seis coisas, completamente moídas e batidas, dentro de uma garrafa e, com um palito curto, dividido em quatro, mexer bem até que a mistura espume. O palito deve entrar somente um pé dentro da garrafa. Então o vinho pode ser bebido.

Pour garis vin boucté. Para curar vinho viscoso: Para um barril de Paris, por uma panela cheia de milho para ferver ao máximo. Amassar e deixar esfriar. Pegar ovos brancos sem pele bem batidos, por estas duas coisas na garrafa e mexer com um palito curto, dividido em quatro, que não alcance a borra nem a perturbe. Pendurar um pouco de cominho negro ${ }^{610}$ dentro de um saco de pano por uma corda através da rolha da garrafa.

Pour garis vin bouté ou qui sente le fust, le mugue ou le pourry. Para curar vinho viscoso, ou vinho que adquiriu cheiro do casco ou gosto de almíscar: Bater dois denários de gengibre junto com dois denários de zedoária ${ }^{611}$ e deixar este pó ferver em dois quartos de vinho, mexendo bem. Despejar na garrafa enquanto está quente e mexer até o fundo. Por a garrafa de pé cuidadosamente e deixar a mistura assentar até estar acomodada.

Pour garir vin qui a aigreur. Para curar vinho que se tornou amargo: Para um barril de vinho, ferver um quarto do mesmo vinho e nele colocar meia onça de folhas de louro. Por isto num recipiente sem mexer nada. $\mathrm{O}$ vinho pode então ser bebido.

Pour garir vin enfusté. Para curar um vinho com gosto de madeira: Para um barril, pegar meia libra ${ }^{612}$ de açúcar, duas onças ${ }^{613}$ de açúcar e meia onça de folhas de louro, misturar tudo isto e por num recipiente, sem mexer. Alternativamente, colocar carvões dentro do casco, manter firme e deixar assentar por aproximadamente três dias.

Pour vin qui a la seive brisiee. Para um vinho que perdeu o buquê: Misturar juntos uma tigela cheia de tanino e uma mão cheia de ervilhas, e por dentro da garrafa. Extrair o vinho sem mexer.

\footnotetext{
${ }^{610}$ Laserpitiumlatifolium

${ }^{611}$ Curcuma.

${ }^{612}$ Libra $=453,59237$.

${ }^{613}$ Onça $=31,103478 \mathrm{~g}$.
} 
Pour esclarcir vin roux em yver. Para clarear um vinho profundamente tinto (vermelho escuro) no inverno: Num barril, sem mexer, por meia libra de amêndoas novas mergulhadas no mesmo vinho. Para clarear a cor do vermelho profundo do vinho no verão, dentro do barril, sem mexer, por duas mãos cheias de folhas de amora. $\mathrm{O}$ vinho pode então ser extraído.

Pour vin vermeil esclarcir. Para clarear um vinho tinto: Pegar quarenta ovos brancos, sem casca, bem batidos, uma mão cheia de sal e duas onças de pimenta em grão, e mergulhar tudo junto em um pouco do vinho. Por isto no casco e mexer tudo junto, borra e tudo. Deixar assentar e então o vinho pode ser extraído.

\section{[Receitas adicionais $(V A T)]^{614}$}

Potaige appellé Menjoire. Sopa chamada Menjoire ${ }^{615}$ : Primeiramente, a carne que deve ser usada: pavões jovens, faisões ou perdiz, ou se estes não puderem ser encontrados, tarambolas, grous, cotovias e outros pássaros menores. Esta carne pode ser assada no espeto e, quando estiver quase pronta, os pássaros grandes, pequenos pavões, faisões e perdizes, podem ser partidos pelos seus membros e fritos em gordura de bacon numa panela de ferro. Colocá-los numa panela cujo caldo já deve ter sido feito. Para esse caldo é preciso de caldo de uma junta de vaca, e pão branco tostado na grelha. Deixar o pão embeber nesse caldo e coar. É preciso de buquê de cássia moído, canela, gengibre de Meca, um pouco de cravos, pimenta longa e grãos do paraíso, e a quantidade de hipocraz ${ }^{616}$ necessária à quantidade de caldo que se quer fazer. Margulhar essas especiarias juntas no hipocraz, adicionar à panela com a carne e o caldo e ferver tudo junto, com um pouquinho de vinagre. Simplesmente deixar ferver. Por uma adequada porção de açúcar. Dependendo da pessoa que estiver fazendo, pode ser guarnecido com obreias ${ }^{617}$ glaceadas por cima, ou com anis vermelho ou branco, ou pode ser salpicado com sementes de maçã vermelha.

Pode-se desejar fazer isto num dia de comer peixe. Pode-se pegar amêndoas inteiras, com casca, lavá-las cuidadosamente, triturá-las e moê-las num pilão e colocá-las no coador. Se não houver líquido suficiente, pegar um pouco de pão branco, ou pedaços de dois ou três pães brancos para ter um pequeno purê leve, no qual as ervilhas não estejam muito moles, um pouco de vinho branco ou escuro e um pouco de agraço, mergulhar as amêndoas e o pão nisto e coar tudo. E é preciso especiarias suficientes de acordo com o mencionado acima. Para carne é preciso perca, lúcio pequeno, pescoços de lagostim e o mais fino cadoz que encontrar. E toda essa carne pode ser frita em manteiga fresca - ou em manteiga salgada, dessalgada. Colocar a carne em pratos e derrubar o molho sobre ela, com anis branco ou vermelho por cima, ou sementes de maçã

\footnotetext{
${ }^{614}$ Toda essa série de receitas pertence apenas ao manuscrito da Vaticana - VAT.

${ }^{615}$ A sopa Menjoire é provavelmente uma receita de inspiração sarracena.

${ }^{616}$ Vinho açucarado com especiarias.

${ }^{617}$ Folhas finas de massa de farinha de trigo.
} 
vermelha, ou amêndoas sem casca que devem ter sido tostadas um pouco no fogo, num pouco de manteiga fresca.

Lassis de blanc de chappon. Capão branco em pedaços: Cozinhar o capão com juntas de vaca. Pegar toda a carne branca do capão e picar como se fosse tosquiar lã. Cortar o restante do capão em peças e fritá-las em gordura de bacon até que estejam levemente coradas. Colocá-las em pratos e por a carne branca picada por cima, descascar e moer amêndoas e mergulhá-las no caldo, pondo um pouco de vinho branco e agraço, gengibre de Meca sem pele em pó e grãos do paraíso, numa proporção de um para dois, e açúcar suficiente para torná-lo doce. É preciso descascar amêndoas brancas e fritá-las em gordura de bacon ou gordura de porco despedaçada e colocá-las no caldo quando ele estiver pronto. Deve ficar espesso o suficiente para as amêndoas boiarem. Salpicar anis vermelho por cima de tudo.

Gravé d'escrevisses. Molho de lagostins: Pegar amêndoas e lavar bem, sem escaldar e descascar e moer. É preciso um purê ralo de ervilha. Cozinhar lagostins grandes em uma mistura de duas partes de água e uma parte de vinho, com um pouco de vinagre, se desejar. Escorrer o líquido, deixar esfriar, por as garras e o pescoço de lado e remover as cascas. Remover a carne do corpo, moer e triturar como se faz com amêndoas, mergulhar num purê de ervilhas, vinho e agraço e por tudo isto junto no coador. Pegar gengibre, um pouco de canela fina, alguns grãos do paraíso, poucos cravos e um pouco de pimenta longa. Fritar as patas e os pescoços dos lagostins num pouco de manteiga, devem ficar secos como cadoz frito, e coloca-los para ferver em uma panela ou em um bom pote limpo. Mergulhar as especiarias em um pouco de vinho e agraço, adicionar uma generosa quantidade de açúcar e ferver tudo junto. Salgar para dar gosto. E pode-se colocar a carne frita nisto, se desejar. Deve ser espesso o suficiente para cobrir a carne.

Un rozé a chair. Um manjar rosa para dias de comer carne: Moer bem amêndoas descascadas, pegar caldo de carne, vinho e agraço. Mergulhar as amêndoas nele e coar. Pegar a carne - isto é, peito de vitela, ou um frango inteiro ou parte dele cozido com junta de vaca ou com algum outro bom corte de vaca - fritar essa carne em gordura de bacon até que fique corada. Pegar uma quantidade bem pequena de canela fina, gengibre de Meca branco, umas poucas especiarias como grãos do paraíso, cravos e pimenta longa. Para colorir você deve ter urzela ${ }^{618}$ e alcana ${ }^{619}$ - alcana é mais apropriado do que urzela. Ela deve ser encharcada em água muito quente, por três ou quatro horas. Então colocar no caldo, depois de fervido e mexer até que alcance a cor própria para um manjar rosa.

Une trimolette de perdrix. Um trimolette ${ }^{620}$ de perdiz: A perdiz deve primeiro ser preparada e assada num espeto até quase estar no ponto. Tirar do espeto e partir em pedaços ou deixar inteira, e por numa boa panela nova. Fatiar cebolas

\footnotetext{
${ }^{618}$ A urzela é liquem que produz um corante violáceo.

${ }^{619}$ A alcana é uma planta com flores azuis, utilizada para se obter corante vermelho.

${ }^{620} \mathrm{O}$ termo trimolette designa um molho picante servido particularmente sobre perdiz.
} 
tão fino quanto possível, fritar num pouco de gordura de bacon com caldo de carne e tostar bastante na grelha. Mergulhar,coar e adicionar sobre a perdiz na panela. Pegar canela fina, um pouco de gengibre, alguns cravos, mais grãos do paraíso e pimenta longa, e mergulhar essas especiarias em bom hipocraz. Então adicionar tudo isto à panela e tampá-la completamente, para que não escape nenhum vapor. Por açúcar. Quando estiver prestes a ser tirado do fogo, adicionar um pouco de vinagre. Não deve ferver.

Brouet de daintiers de cerf. Caldo de testículos de veado: Eles precisam primeiro ser totalmente escaldados, lavados em água fervendo, bem cozidos, e então esfriados, cortados em cubos de tamanho moderado e fritos em gordura de bacon. Na mesma panela, por caldo de carne, folhas de salsa e suficientes especiarias que não deixem por demais temperado. Providenciar um líquido, um pouco de camelino pode ser usado ou pegar um ou dois fígados de frango, um pouco de pão branco, moê-los na panela, no lugar do camelino. Por um pouco de vinagre, mergulhar as especiarias em vinho e agraço numa proporção de um para dois ou, em vez de agraço, suco de groselha, e sal para dar sabor.

Flaons cochus. Flãs cozidos: Adicionar um creme de gemas de ovos bem batidas. Pegar conchas de massa de um tamanho maior que o normal, colocar especiarias em pó fino ou branco na mistura de ovo e creme. Pegar enguias grandes, do tamanho de um punho, escaldá-las, assá-las bem, fatiá-las e colocar as partes redondas nos pudins, três ou quatro em cada. Por muito açúcar sobre eles quando estiverem cozidos e deixar esfriar.

Doreures. Dourados: Um entremez para dia de festa ou para um banquete principesco nos três dias de comer carne da semana, a saber, domingo, terça e quinta. Para rechear e para almôndegas: é preciso, para as bolotas, porco cru, o corte do porco não importa, com o qual as galinhas devem ser recheadas. Depois que a ave estiver morta, pode-se fazer um corte na pele da cabeça e soprar através da plumagem oca até a pele inflar. Escaldar as aves e cortá-las embaixo da barriga e da pele, reservar as carcaças. Para fazer o recheio das aves é preciso ter carne branca, bacon picado com a carne, ovos, boas especiarias em pó fino, pasta de pinhão e groselha. Rechear a pele das aves com isto, sem exagerar e rompê-la. Então costurar de novo. Devem ser fervidas numa panela no fogo e quase cozidas. Montá-las em espetos finos. E quando as almôndegas estiverem bem feitas, podem ser colocadas para cozinhar com as aves. Tirá-las quando tiverem endurecido. Para as bolotas, pegar espetos da metade da grossura dos espetos das aves. Depois disso, deve-se ter batido ovos, leite e farinha o suficiente para misturar no pão. Quando as aves e as almôndegas estiverem quase cozidas, removê-las e colocá-las na mistura batida, pegar a mistura com uma concha limpa, mexendo constantemente, e por sobre as aves e as almôndegas, até que elas estejam envolvidas nisto. Faça isto duas ou três vezes, até que as aves estejam totalmente revestidas. Então é preciso pegar folha de ouro ou folha de prata e envolvê-las. É necessário umedecê-las com um pouco de clara de ovo para a folha colar melhor. 
Coqz heaumez. Galos com elmo: Assar leitões e aves como galos e galinhas velhas. Quando ambos, o leitão e as aves estiverem assados, as aves devem ser recheadas sem tirar a pele, se quiser. Devem ser envolvidas em mistura de ovo, leite e farinha batidos. Quando estiverem envolvidas nessa mistura, podem ser colocadas ao lado do leitão. É necessário um elmo de papel com cola e uma lança espetada no peito da ave, e isto deve estar coberto por uma folha dourada ou prateada para os nobres, ou com folha de lata branca, vermelha ou verde.

Tourtes parmeriennes. Tortas de parmesão: Pegar carneiro, vitela ou porco e cortar em pedaços suficientemente pequenos. Ferver aves e cortá-las em pedaços - e a outra carne precisa ser cozida antes de ser cortada. Pegar pó fino de especiarias e salpicar na carne delicadamente. Fritar carne em gordura de bacon. Pegar grandes conchas de massa - que devem ter beiradas mais largas do que o usual e serem do tamanho de pratos pequenos - e moldá-las em forma de torres. Elas devem ser de uma massa forte o suficiente para sustentar a carne. Se quiser, pode misturar pasta de pinhão e groselhas na carne, com açúcar granulado por cima. Em cada massa colocar três ou quatro pedaços de frango, nos quais colocar bandeiras da França e dos nobres que estarão presentes e as glacear com açafrão umedecido para dar-lhes uma aparência melhor. Para quem não quer gastar tanto com aves, fazer gordas peças de porco ou carneiro, igualmente assados e fervidos. Quando as tortas estiverem recheadas com a carne, a carne de cima deve ser glaceada com um pouco de ovo batido, gemas e claras, assim essa carne permanecerá solidamente junta, o suficiente para segurar as bandeiras. E se deve ter folhas douradas, prateadas ou de lata para glacear as tortas antes de colocar as bandeiras nelas.

Tostees dorees. Torradas douradas: Para fazer torradas douradas, fatiar pão branco duro em quadrados para torrar e assá-lo delicadamente na grelha. Cobrilos totalmente com gemas de ovos batidas. Pegar boa gordura quente e mergulhar as fatias nela, no fogo, até que estejam suficientemente glaceadas. Então tirá-las da panela e colocá-las em pratos, polvilhando açúcar por cima.

Blanc menger party. Manjar branco festivo: Pegar amêndoas escaldadas e descascadas, moer bem e mergulhar em água fervendo. Para ligá-las é preciso de arroz batido ou amido. Quando o leite estiver fervido, deverá ser dividido em várias partes - em duas se quiser fazer um manjar somente de duas cores e, se quiser, em três ou quatro partes. Ele deve ser bem espesso, tanto quanto frumento, assim não poderá desmanchar quando for colocado no prato ou na tigela. Pegar alcana ou urzela ou azurita ${ }^{621}$ fina ou salsa ou hortelã ou um pouco de açafrão moído com a verdura de modo que mantenha melhor sua cor durante a fervura. Deve-se ter gordura de bacon e alcana ou urzela para embeber, e caso contrário, azurita. Adicionar açúcar ao leite quando ferver o suficiente para ser tirado do fogo, salgá-lo, mexer fortemente até que tenha engrossado e adquirido a cor que se quer dar a ele.

\footnotetext{
${ }^{621}$ A azurita é um carbonato de cobre de cor azul.
} 
Layt lardé. Leite entremeado: Por leite para ferver no fogo, pegar gemas de ovos batidas, tirar o leite do fogo, colocá-lo sobre alguns carvões e jogar os ovos dentro. Se quiser este prato em um dia de comer carne, pegar fatias finas de bacon, cortar em dois ou três pedaços e por com o leite para ferver. Se quiser o prato para um dia de peixe, não deverá por bacon. Adicionar vinho e agraço antes de colocar o bacon para fazer o leite coalhar. Tirar do fogo, por num pano limpo, deixar drenar, envolver em duas ou três camadas de pano e espremer até ficar tão duro quanto um bife de fígado. Por na mesa e cortar em fatias do tamanho da palma de sua mão ou de três dedos. Entremear com cravos, fritar até que esteja corado. Servir guarnecido de açúcar.

Tourtes de layt. Tortas de leite: Por o leite para ferver em fogo baixo. Deve-se ter ovos mexidos juntos, ou com as claras, se quiser. Quando o leite ferver, dividir em duas travessas. Por salsa na metade dos ovos e adicionar suficiente vinho e agraço para coalhar, por para esfriar até um ponto em que se possa por a mão. Pegar um coador de pano de dois pés de comprimento, pegar uma ou duas conchas cheias do leite e derramar em duas ou três vezes no coador, esfregar fortemente com as mãos e quando estiver assentado e duro, tirar do coador, por para esfriar e espetar duas ou três fileiras de cravo. Fritar em gordura de bacon até que fiquem coradas. Devem ser servidas com leite entremeado em um prato, metade um e metade o outro.

Buignetz et roysolles de mouelle. Bolinhos fritos e rissoles de tutano ${ }^{622}$ Crespes grandes et petites. Crepes grandes e pequenos: Os grandes são feitos com um pote de calda ou uma panela grande de bronze. Os pequenos, com uma panela de ferro. Devem ser feitos com gemas de ovos e farinha batidos juntos. Pegar uma tigela funda de madeira e gordura quente, por a mistura batida na tigela, que não pode estar muito espessa, e colocar uma mão de massa da tigela na gordura quente. Evitar que fiquem muito marrons. Para crepes pequenos pode-se bater gemas e claras juntas com a farinha e isto deve ficar um pouco mais espesso do que a mistura para os crepes grandes. Manter o fogo baixo enquanto a gordura está quente, pegar uma tigela de madeira com um buraco no fundo, por a mistura nela e quando tudo estiver pronto, deixar escorrer para fora e fazer uma espécie de pequeno laço, ou um grande, e através do laço fazer um tipo de lingueta de fivela com a mesma mistura. Deixar os crepes cozinharem na gordura até que eles tenham inchado.

Pipesfarces. Tubos recheados: Se quer fazer tubos recheados, deve ter um bom e rico queijo em fatias da grossura de um dedo e envolvê-los numa mistura igual à dos crepes pequenos. Mergulhar as fatias de queijo em gordura quente, evitando queimá-las. Quando estiverem secas e amareladas, tirar como os crepes.

Aloyaulx. Pequenas cotovias: Pegar tutano de vaca ou a gordura da carne do rim e fatiar em peças da grossura de um dedo. Mergulhar o tutano em água quente, simplesmente colocando e tirando, fazendo o mesmo com a gordura,

${ }^{622}$ Apenas o título foi copiado no manuscrito. 
mas por mais tempo. Pegar uma junta de vitela e remover a carne dos ossos em peças contínuas tanto quanto possível e cortar em fatias muito finas, mais finas que uma hóstia. Deixá-las de lado numa borda limpa e envolver as peças de tutano com fatias de vitela com um pouco de sal branco e com especiarias em pó fino ou branco. Montá-las num espeto de ferro bem fino. Fazer uma mistura igual à dos crepes pequenos e envolver os espetos quando estes estiverem bem cozidos - é assim tanto quanto diz respeito a tutanos.

Dyapré. Manjar ornamentado: O mesmo que foi feito com o manjar de amêndoas e com o manjar rosa, acima, mas não lhe deve ser dada uma cor tão pronunciada e não se deve mexer tanto na panela, como no manjar rosa. É preciso somente uma boa quantidade de açúcar, tanto num caldo como no outro; é necessário bastante carne frita em gordura de bacon, exatamente como no outro prato.

Tuillé. Ladrilhado: Lavar amêndoas descascadas e moer bem, colocá-las em caldo de carne, vinho e agraço, adicionar as mesmas especiarias usadas no manjar rosa e no manjar ornamentado, exceto que este necessita mais canela, comum e boa, e similarmente este necessita carne de aves e vitela fritas em gordura de bacon, e uma boa quantidade de açúcar a ponto de ficar doce. Em dias de comer peixe: se desejar mudar estas iguarias para dias de comer peixe, e não tiver agraço, pegar água fervendo e jogar amêndoas com a casca. Para a carne é preciso de perca e lúcio e fervê-los até que possa tirar suas peles, fritálos em manteiga fresca e usar especiarias como no manjar ornamentado e no majar rosa: gengibre, canela e outras. Se não tiver peixe de água doce, usar linguado, solha e solha-escura. Pode ser generoso com o açúcar, mais do que com as iguarias acima, para dias de carne. Deve ser adequadamente salgado.

Tailliz de Karesme. Fatias da Quaresma: Moer muito bem amêndoas sem pele num pilão, pegar água fervida morna, jogar nela as amêndoas, coar e ferver esse leite em poucos carvões. Pegar biscoitos secos de um ou dois dias atrás e cortálos em pequenos pedaços do tamanho de um grande dado. Pegar figos, tâmaras, uvas sem sementes, cortar os figos e as tâmaras como os biscoitos, despejar tudo no leite, deixar ficar tão espesso quanto frumento, e adicionar açúcar para ferver com ele. O leite de amêndoas deve ferver bem pouco. Para dar uma cor pode-se usar açafrão, como no frumento. Salgar levemente.

Pastez nourroys. Tortas nórdicas: Pegar carne muito bem cozida, fatiada bem fina, pasta de pinhões, groselhas, queijo rico finamente cortado, um pouco de açúcar e muito pouco sal.

Petis pastez lorez. Pequenas ${ }^{623}$ bolsinhas $^{624}$ (pastéis): Amassar cerca de um blanc de massa ou menos, fritar com seus lados não muito grossos. Se desejar fazer folhas de alface ou pequenas orelhas ${ }^{625}$, é preciso fazer coberturas de massa, umas maiores do que as outras. Fritá-las em gordura de porco pura até

\footnotetext{
${ }^{623}$ Pode-se interpretar que os pastéis deveriam ter o tamanho da moeda chamada um blanc, ou que deveram ter o tamanho dos pastéis que podiam ser comprados por um blanc.

${ }^{624}$ A palavra lorez provavelmente equivale ao francês loure, do latim, lura, ou bolsa.

${ }^{625}$ As laictues e as oireillettes aparecem listadas nos menus do Ménagier.
} 
que elas estejam duras como se cozidas num forno. E se quiser, elas podem ser envolvidas em folhas douradas ou prateadas, ou com açafrão.

Herissons et petz d'Espaigne. Ouriços e potes espanhóis ${ }^{626}$ : Cortar a carne crua tão pequeno quanto possível, misturar uvas sem sementes e rico queijo cortado junto com especiarias em pó fino, pegar estômagos de ovelha, escaldar e lavar muito bem, mas não em água tão quente que os desmanche, e preencher com a carne cortada. Costurar com uma pequena agulha de madeira.

Petz d'Espaigne. Potes espanhois ${ }^{627}$ : Se quer fazer potes espanholas, é preciso pegar pequenos potes como os potes de barro para água, e umedecer seu interior com clara de ovos até sentir que vai aderir melhor. Enchê-los e deixar ferver no fogo, numa panela ou caldeirão. Quando estiverem bem cozidos, tirar e deixar escorrer. Quando estiverem frios, quebrar os potes sem estragar a parte de dentro. Pegar espetos finos - não tão pequenos quanto os dos ouriços. Pode-se fazer pequenas almôndegas e colocá-las em espetos em linhas de duas ou três. Envolvê-las em uma mistura de farinha.

Espaules de moutons farcies. Motes et mangonneaulx. Ombro de cordeiro recheado. Torres e catapultas: Ombros de carneiro devem ser cozidos numa panela no fogo, da mesma forma que as pernas do carneiro ou do porco - não os cozinhar demais, deixá-los esfriar. Retirar a carne dos ossos e cortá-la muito fina. Para as Torres e Catapultas, da mesma maneira, pegar pasta de pinhão, groselhas e um grande omelete de ovos fritos em gordura branca de bacon, e cortá-los em pequenos pedaços do tamanho de um grande dado, evitando queimá-los. Pegar todos estes ingredientes, junto com creme de queijo esmigalhado, por tudo numa panela limpa ou tigela e misturar bastante. É preciso de membrana de ovelha: espalhá-la, salpicar com especiarias em pó fino e por os ossos sobre ela, sem o recheio. Empacotar os ossos com a membrana de ovelha e costurá-los juntos com uma pequena agulha de madeira, para evitar que a carne desmorone para longe dos ombros - como os ajudantes de cozinha sabem como fazer. As torres são feitas como pequenas tortas, as catapultas são tão longas quanto tripas de porco. Embrulhá-las na membrana e besuntá-las apropriadamente com ovos. Para o resto, fazer o que é pedido em cada caso.

Cignes revestuz. Cisnes revestidos ${ }^{628}$ : Devem ser inflados e ter a pele retirada, escaldados antes de tirar a pele. Cortá-los pela barriga e remover as carcaças. Assar as carcaças num espeto e envolvê-las, como estão, com uma mistura de ovos, gemas e claras juntas. Removê-las do espeto, deixar esfriar e envolvê-las em sua pele, se desejar. Devem-se ter pequenos espetos de madeira para colocar em seu pescoço e mantê-lo ereto como se a ave estivesse viva. Esse é o segundo serviço de um banquete.

\footnotetext{
${ }^{626}$ Herissons et petz d'Espaigne constam no mesmo título por apresentarem o mesmo recheio de carne picada, umas sem semente, queijo cremoso e especiarias, comumente denominado simplesmente farce. ${ }^{627}$ Trata-se de um entremez do mesmo tipo da receita anterior, listado também nos menus do Ménagier 628 Trata-se do entremez mais comum do período. Note que essa receita posterior é muito mais pormenorizada do que a receita 72 (século XIV ou anterior).
} 
Paons. Pavões [revestidos]: Devem ser soprados e inflados como os cisnes, assados e glaceados do mesmo jeito. Devem ser servidos no último serviço. Quando revestidos, pode-se pegar espetos bem finos para passar através das penas da calda ou um pequeno fio metálico para manter as penas de pé como se o pavão estivesse abrindo seu leque.

Le Chevalier au Cigne. O cavaleiro do cisne (entremez artístico ${ }^{629}$ ): Se desejar fazer um cavaleiro no cisne de forma realista, é preciso pegar 12 pequenas peças de madeira, 4 das quais ficarão de pé e deverão ser mais fortes do que as outras. Montar e pregar tudo fortemente. Colocar ao longo de um tecido de três pés de comprimento e suficientemente largo. Será preciso dois a três tecidos de cobertura, e fazer uma espécie de caixa, a qual terá cerca de um pé de comprimento, de modo a comportar 2 ou 3 baldes de água. Fazer um pequeno barco de pergaminho colado ou a imagem do cavaleiro no cisne. Também, a aparência de um pequeno cisne feito de pergaminho colado coberto com arminho ${ }^{630}$ ou lanugem branca. É preciso uma pequena corrente para pendurar no pescoço do cisne, presa ao barco através da caixa condutora. Nesta caixa, 4 rodas devem ser fixadas e 4 eixos, de modo que ela possa ser puxada de um lado para outro. Ela deve ter pano pintado com ondas para parecer água, pregado no alto da caixa, de modo que os homens embaixo não possam ser vistos $^{631}$.

Une tour. Uma torre (entremez artístico): Se desejar fazer uma torre coberta com pano pintado, como se ela fosse de alvenaria, ela tem que ter 4 janelas nos 4 cantos e nelas deve haver algo como sarracenos e mouros atirando no homem distante que está tentando atacá-los. Para fazer o homem distante é preciso um homem alto, elegante, bonito, vestido com uma túnica de linho, com calças e sapatos de material correspondente, e a túnica deve estar completamente coberta com cânhamo pintado. Na torre é necessária a representação de um jovem rapaz, que está disfarçado como o jovem distante. Ele deve ter bolas de couro, preenchidas com flocos de lã ou fios, pintadas para que pareçam pedras, para atirar no homem distante ${ }^{632}$.

Saint George et sa pucelle. São Jorge e sua criada ${ }^{633}$ (entremez artístico): Para representar São Jorge e sua criada é preciso fazer uma grande plataforma de massa ou de madeira clara como são os campos, e fazer algo como um cavalo, selado e arreado, a imagem de São Jorge no cavalo, um dragão sob os cascos do cavalo, e a criada que está conduzindo o dragão, o qual está preso pelo pescoço pelo cinto dela.

\footnotetext{
${ }^{629}$ Paintrerie. Era comum um tipo de entremez que não se destinava ao consumo e não consistia em alimentos. Eram peças artísticas esculpidas e pintadas que utilizavam telas, tintas e outros materiais.

${ }^{630}$ Pelo de animal branco usado em mantos cerimoniais.

${ }^{631}$ A lenda do Cavaleiro do Cisne foi uma das mais difundidas nos círculos aristocráticos do final da Idade Média. Ver Roman Du Chevalier Du Cygneet de Godefroid de Bouillon, Ed. M. de Reiffemberg e A. Bornet.

${ }^{632}$ A cena parece inspirada em uma narrativa em voga no início do século XV, que aparece algumas vezes em tapeçarias, conforme estudo de Madeleine Jarry.

${ }^{633} \mathrm{O}$ entremez apresenta o tema de São Jorge, que figura na Legenda Áurea de Jaccopo de Varazze (Cia das Letras, 2003).
} 
Saincte Marthe. Santa Marta (entremez artístico): Para representar Santa Marta, é preciso fazer a imagem de Santa Marta com o dragão inteiro ao lado dela e, em volta do pescoço do dragão, uma corrente dourada pela qual a santa vai conduzi-lo, como se ela o houvesse domado. Esta figura pode ser feita por duas pessoas, se quiser, ou um trabalho pintado, não importa o peso e o tamanho que desejar ${ }^{634}$.

Entremetz plus legiers. Entremezes mais fáceis (entremez artístico): Podemse fazer plataformas de pão grosseiro e representar uma donzela sentada na plataforma, a qual pode ser coberta com folha de lata pintada para parecer verde e gramada. É preciso um leão que terá suas duas patas fronteiras e sua cabeça no colo da donzela. Isso pode ser feito com uma boca de latão revestido e uma língua de latão fino, e com papel, dentes colados na boca. Por cânfora num pouco de algodão na boca e, quando estiver para ser servido aos nobres, por fogo no algodão. Se quer representar um lobo, um urso, uma zebra, uma serpente ou qualquer outro animal, doméstico ou selvagem, eles podem ser feitos do mesmo modo que o leão, cada um no seu modelo.

La poulse pour un chappon gras. Poulse ${ }^{635}$ para um capão gordo: Coletar gordura do capão, assim como o fígado e passar no coador com caldo de carne. Mergulhar um pouco de gengibre em agraço e por tudo junto para ferver numa panela. Ligar isto com gemas de ovos batidas, adicionar uma generosa quantidade de açúcar. Remover as asas e pernas do capão e regar o molho por cima.

\footnotetext{
${ }^{634}$ A história de Santa Marta também é apresentada na Legenda Áurea de Jaccopo de Varazze (Cia das Letras, 2003).

${ }^{635} \mathrm{~A}$ pulse parece designar um modo de preparo que visa tornar a carne de capão mais tenra.
} 


\section{Fontes e bibliografia}

\section{Documentação - Edições}

\section{Le Viandier de Taillevamt}

SCULLY, Terence. The Viandier of Taillevent. Ottawa: University of Ottawa Press, 1988.

PICHON, Jerôme; VICAIRE, Georges. Le Viandier de Guillaume Tirel dit Taillevent. Paris: Techener, 1892. Disponível em: <http//gallica.bnf.fr>. Acesso em: 10 jan. 2013.

\section{Le Ménagier de Paris e Cocanha}

BRERETON, Georgine; FERRIER, Janet. (Orgs.). Le Ménagier de Paris. Oxford: Oxford University Press, 1981.

PICHON, Jerôme. Le ménagier de Paris: traité de morale et d'économie domestique. Paris: 1846.

Disponível

em:

$<$ http://books.google.com.br/books?id=8SY_AAAAcAAJ\&printsec=frontcover\&hl=pt$\mathrm{BR} \# \mathrm{v}=$ onepage $\& \mathrm{q} \& \mathrm{f}=$ false $>$. Acesso em: 07 abr. 2013.

POWER, Eileen. The Goodman of Paris: A treatise on moral and domestic economy by a citizen of Paris, c.1393. New York: Boydell Press, 2008.

V. VÄÄNÄNEN. (Ed.). Le Fabliau de Cocagne. Neuphilologische Mitteilumgen, 48, 1947, p. 3 36. In: FRANCO JR, Hilário. Cocanha: várias faces de uma utopia. São Paulo: Ateliê Editorial, 1998. 


\section{Documentação de apoio}

ALDEBRANDINO DE SIENA. O regime do corpo. Edição L. Landouzy e R. Pépin, Paris, 1911. In: LAURIOUX, Bruno. A Idade Média à mesa. Tradução Elsa Andringa. Sintra: Publicações Europa-América, 1989.

BARTOLOMEU, o Inglês. Livro das propriedades das coisas. Tradução francesa de Jean Corbechon, Biblioteca Nacional, manuscrito fr. 22532, fols. 246 e 267. In: LAURIOUX, Bruno. A Idade Média à mesa. Tradução Elsa Andringa. Sintra: Publicações Europa-América, 1989.

GIOVANNI BOCACCIO. Decameron. VIII, 3. M. MARTI. (Ed.). 9a ed. Milão: Rizzoli, 1992, v. II, p. 522-531. In: FRANCO JR, Hilário Cocanha: várias faces de uma utopia. São Paulo: Ateliê Editorial, 1998, p. 55-60.

CARÊME. Enseignements. In: LOZINSKI, Grigory Leonidovich. La Bataille de Caresme et de Charnage. Édition critique "De Caresme et de Charnage". Paris, 1933. 218 p. (Série Bibliothèque de l'École des Hautes Etudes. Sciences historiques et philologiques. Fasc. 262). Disponível em: $<$ http://www.worldcat.org/title/la-bataille-decaresme-et-de-charnage-edition-critique-of-the-poem-de-quaresme-et-de-charnagefrom-ms-fr-837-in-the-bibliotheque-nationale-avec-introduction-et-glossaire-pargregoire-lozinski/oclc/561850603>. Acesso em: 27 out. 2012.

CHIQUART. Fait de cuisine. In: SCULLY, Terence. Du fait de cuisine par Maistre Chiquart, 1420. Vallesia, 1985.

GALENO. L'âme et ses passions; les passions et les erreurs de lame. Les facultes de 1'^ame suivent lês tempéraments Du corps. Prefácio de Jean Starobinski. Tradução, introdução e notas Vincent Barras, Terpsichore Birchler; Anne-France Morand. Paris: Les belles Lettres, 1995.

On food and diet. Introdução, edição, tradução e comentários de Mark Grant. Londres: Routledge, 2000.

HERÁCLITO. Doxografia. In: Os filósofos pré-socráticos. Tradução Gerd. A. Bornheim. São Paulo: Cultrix, 1967.

HILÁRIO DE POITIERS. La Trinité. Edição e tradução de G. M. Durand; Ch. Morel e G. Pelland. SC, 1999. 
HIPÓCRATES. Regimen II. Edição e tradução W.H.S. Jones. Londres: Harvard University Press, 1931.

Nature of man. Edição e tradução W.H.S. Jones. Londres: Harvard University Press, 1931.

Sobre la dieta. In: Juramento hipocrático y tratados médicos. Tradução Carlos Garcia Gual. Argentina: Planeta-De Agostini, 1995.

HOMERO. Odisseia. In: EGERTON, March. Since Eve ate apples. Portland: Tsunami Press, p.179-180.

INNOCENT. De contemptu mundi, sive de miseria humanae. Charleston: Bibliolife, 2009.

NILO. Tractus de octo spiritibus malitiae. PG, v.79, col. 1145B1146B.

SACHS, Hans. Das Schalaweraffenlandt. Ed. E. Goetze em Samtliche Fabeln und Schwänke, Halle, Max Niemeyer, 1893, p. 8-11. In: FRANCO JR, Hilário. Cocanha: várias faces de uma utopia. São Paulo: Ateliê Editorial, 1998, p. 77-85.

TOURS, Gregory of. A history of the Franks. Chicago: Acheron Press, 2012.

CHACONA. Em Romancero de romances doctrinales, amatorios, festivos, jocosos, satíricos y burlescos sacados de varias colleciones generales y de lãs obras de diversos poetas de los siglos XV, XVI y XVII, 67. Ed. A. Duran, Madrid, Amarita, 1829, p. 282283. In: FRANCO JR, Hilário. Cocanha: várias faces de uma utopia. São Paulo: Ateliê Editorial, 1998, p. 145-150.

DIE IT VAN DATE DELE VAN COCKAENGEN. Ed. R. PriebschTijdschrift voor nederlandsche Taal en Letterkunde, 13, 1894, p. 185-192. In: FRANCO JR, Hilário. Cocanha: várias faces de uma utopia. São Paulo: Ateliê Editorial, 1998, p. 61-68.

IL PIACEVOlE VIAGgiO DI CUCCAGNA. Ed. P. Camporesi, apêndice de "Carnavale, Cuccagna e giuochi di villa", Studi e problemi di critica testuale, 10, 1975, p. 93-97. In: FRANCO JR, Hilário. Cocanha: várias faces de uma utopia. São Paulo: Ateliê Editorial, 1998, p. 131-143. 
JAUJA. Em RUEDA, Lope de. Pasos, 5, ed. Ollé González, e V. Tusón. Madrid: Cátedra, p. 157-165. In: FRANCO JR, Hilário. Cocanha: várias faces de uma utopia. São Paulo: Ateliê Editorial, 1998, p. 97-104.

JOURNAL D'UN BOURGEOIS DE PARIS. Ed. BEAUNE, Collete. Paris: Livre de Poche, 1990.

LAND OF COKAYGNE. Ed. W. Heuser, Die Kildare-Gedichte. Die Altesten Mittelengischen Denkmäler. In: Anglo-Iricher Uberlieferung, Bonn, Hanstein, 1904, p. 141- 150. In: FRANCO JR, Hilário. Cocanha: várias faces de uma utopia. São Paulo: Ateliê Editorial, 1998, p. 33-46.

REGINO DE PRÜM. De ecclesiasticis disciplinis. In: MIGNE PATROLOGIA LATINA. Disponível em: <http://www.documentacatholicaomnia.eu/30_10_08820915-_Regino_Prumiensis_Abbas.html>. Acesso em: 05 set. 2012.

PANIGON. Em Familiere description du tres vinoporratimalvoise et tres envitaillegoulement royaume panigonnis, mystiquement interprete l'isle de Crevepance. Ed. A. Huon, em Le Roy Sainct Panigon dans l'imagerie populaire du XVI sicle, en François Rabelais, Ouvrage publié pour le quatriéme centenaire de sa mort. GenebraLille: Droz-Giard, 1953, p. 221-225. In: FRANCO JR, Hilário. Cocanha: várias faces de uma utopia. São Paulo: Ateliê Editorial, 1998, p. 113-126.

TACITUS. Germânis: de origine et situ germanorum. Tradução João Penteado Erskine Stevenson. São Paulo: Brasil Editora, 1952. (Biblioteca de autores célebres, 24).

TRACTUS DE MODO PRAEPARANDI ET CONDIENDI OMNIA CIBARIA. Origem desconhecida, em MULLON, Marianne. Deux traités inédits d'art culinaire medieval. Paris: Bulletin phillologique et historique du Comité des travaux historiques et scientifiques, 1970. In: LAURIOUX, Bruno. A Idade Média à mesa. Tradução Elsa Andringa. Sintra: Publicações Europa-América, 1989.

VAN LUYE LANDT. Ed. E. Ackermann, Das Schlaraffenland. In: German Literature and Floksong. Chicago: Univrsity of Chicago Press, 1944, p. 162-165. In: FRANCO JR, Hilário. Cocanha: várias faces de uma utopia. São Paulo: Ateliê Editorial, 1998, p. 8795.

VOM SCHLARAFFENLAND. Ed. M.Haupt, e H Hoffman. In: Autdeutshche Blätter. Leipzig: Brockhaus, 1836, v. 1, p. 163-170. In: FRANCO JR, Hilário. Cocanha: várias faces de uma utopia. São Paulo: Ateliê Editorial, 1998, p. 47-53. 


\section{BIBLIOGRAFIA GERAL}

ADANS, Carol. Sexual politic of meat: a feminist-vegetariam critical theory. New York: Continuum, 1990.

ALCOTT, Willian. The world is a mighty slaughterhouse and flesh- eating and human decimation. In: WALTERS, Kerry S.; PORTNESS, Lisa. (Org.). Ethical vegetanianism: from Pythagoras to Peter Singer. Albany: State University of New York Press, 1999.

ALEXANDRE-BIDON, Danièle F. Banquete de imagens e "hors d'oeuvre" iluminados. In: FLANDRIN, Jean Louis; MONTANARI, Massimo. (Org.). História da alimentação. Tradução Luciano Vieira Machado; Guilherme J. F. Teixeira. São Paulo: Estação Liberdade, 1998, p. 521-529.

ALTHOFF, Gerd. Comer compromete: refeições, banquetes e festas. In: FLANDRIN, Jean Louis; MONTANARI, Massimo. (Org.). História da alimentação. Tradução Luciano Vieira Machado; Guilherme J. F. Teixeira. São Paulo: Estação Liberdade, 1998, p.3 00-310.

ANDERSON, Perry. Passagens da Antiguidade ao Feudalismo. São Paulo: Brasiliense, 1987.

ASFORA, Wanessa. Apício: história da incorporação de um livro de cozinha na Alta Idade Média (séculos VIII e IX). 2009. 272 f. Dissertação (Mestrado em História Social) - Faculdade de Filosofia, Letras e Ciências Humanas, Universidade de São Paulo, São Paulo, 2009.

AUSTIN, Thomas. Two fifteenth-century cookery books. Londres: Early English Text Society Original Series, 2004.

BALARD, Michel; DUCELLIER, Alain. Bizâncio e o Ocidente. Tradução Rivair Macedo. In: LE GOFF, Jacques; SCHMITT, Jean-Claude. (Org.). Dicionário temático do Ocidente Medieval. São Paulo: Edusc, v. 1, 2006, p. 119-128.

BAKHTIN, Mikhail. A cultura popular na Idade Média e no Renascimento: o contexto de François Rabelais. Tradução Yara Frateschi Vieira. São Paulo: Hucitec; Brasília: Editora da Universidade de Brasília, 1987. 
BÉDIER, Joseph. Les fabliaux: études de littérature populaire et d'histoire littéraire du Moyen Âge. Charleston: Nabu Press, 2011.

BELASCO, Warren. O que iremos comer amanhã? São Paulo: Senac, 2009.

BERLIOZ, Jacques Flagelos. Tradução Vivian Coutinho de Almeida. In: LE GOFF, Jacques; SCHMITT, Jean-Claude. (Org.). Dicionário temático do Ocidente Medieval. São Paulo: Edusc, v. 1, 2006, p. 457-471.

BLOCH, Marc. Tecnique et évolution sociale: réflexions d'un historien. Europe, 47, 1938, p. 23-32. In: BLOCH, Marc. Mélanges historiques, Paris, SEVPEN, 1963.

BLOCH, R, Howard. Medieval French Literature and Law. University of California Press, 1977.

BRAUDEL, Fernand. História e ciências sociais. Tradução Carlos Braga; Inácia Canelas. São Paulo: Martins Fontes, 1972.

. Civilização material e capitalismo. São Paulo: Martins Fontes, 1995.

BRAUNSTEIN, Philippe. Artesãos. Tradução Vivian Coutinho de Almeida. In: LE GOFF, Jacques; SCHMITT, Jean-Claude. (Org.). Dicionário temático do Ocidente Medieval. São Paulo: Edusc, v. 1, 2006, p. 83-90.

BURKE, Peter. O que é história cultural. Rio de Janeiro: Zahar, 2005.

BROWN, Peter. Corpo e sociedade: o homem, a mulher e a renúncia sexual no início do cristianismo. Tradução V. Ribeiro. Rio de Janeiro: Zahar, 1990.

BRUMBERG, Joan Jacobs. Fasting girls: the history of anorexia nervos. Nova York, 1989.

CASAGRANDE, Carla; VECCHIO, Silvana. Pecado. Tradução Lênia Márcia Mongelli In: LE GOFF, Jacques; SCHMITT, Jean-Claude. (Org.). Dicionário temático do Ocidente Medieval. São Paulo: Edusc, v. 2, 2006, p. 337-351.

CARNEIRO, Henrique. Comida e sociedade: uma história da alimentação. Rio de Janeiro: Editorial Presença, 2003. 
. Pequena enciclopédia da história das drogas e bebidas. Rio de Janeiro: Elsevier/Campus, 2005.

. Bebida, abstinência e temperança. São Paulo: Senac, 2010.

CASSIRER, Ernst. The problem of knowledge: philosophy, science, and Hhistory since Hegel. Translated Willian W. Woglom; Charles H. Hendel. Disponível em: $<$ http://www.questia.com/read/56851373/the-problem-of-knowledge-philosophyscience-and $>$. Acesso em: 17 out. 2012.

CONTAMINE, Philippe. La vie quotidienne pendantla guerre de Cent Ans. Paris: Hachette, 1976.

CONTRERAS, Jesús. Los aspectos culturales em el consume de carne. In: ARNAIZ, Mabel Garcia. (Coord.). Somos lo que comemos: estúdios de alimentación y cultura em España. Barcelona: Ariel, 2002.

CORBIER, Mireille. A fava e a moréia: hierarquias sociais dos alimentos em Roma. In: FLANDRIN, Jean Louis; MONTANARI, Massimo. (Org.). História da alimentação. Tradução Luciano Vieira Machado; Guilherme J. F. Teixeira. São Paulo: Estação Liberdade, 1998, p. 217-237.

CORTONESI, Alfio. Cultura de subsistência e mercado: a alimentação rural e urbana na baixa Idade Média. In: FLANDRIN, Jean Louis; MONTANARI, Massimo. (Org.). História da alimentação. Tradução Luciano Vieira Machado; Guilherme J. F. Teixeira. São Paulo: Estação Liberdade, 1998, p. 409-421.

DELORT, Robert. Animais. Tradução Vivian Coutinho de Almeida. In: LE GOFF, Jacques; SCHMITT, Jean-Claude. (Org.). Dicionário temático do Ocidente Medieval. São Paulo: Edusc, v. 1, 2006, p. 57-67.

DETIENNE, Marcel; VERNANT, Jean-Pierre. La cuisine du sacrifice em pays grec. Paris: Gallimard, 1979.

DELUMEAU, Jean. O Pecado e o medo: a culpabilização no Ocidente (séculos XIIXVIII). Tradução Álvaro Lorencini. Bauru: EDUSC, 2003.

DESPORTES, Miguel Angel Motis. A alimentação judia na Idade Média. In: FLANDRIN, Jean Louis; MONTANARI, Massimo. (Org.). História da alimentação. 
Tradução Luciano Vieira Machado; Guilherme J. F. Teixeira. São Paulo: Estação Liberdade, 1998, p. 359-379.

DETIENNE, Marcel. Culinary pratices and the spirit of sacrifice. In: DETIENNE, Marcel; VERNANT, Jean-Pierre. The cuisine of sacrifice among the greeks. Translation Paula Eissing. Chicago and London: The University of Chicago Press, 1989.

DUBY, George. Economia rural e vida no campo no Ocidente medieval. Lisboa, 1987 p. 91-118.

A Europa na Idade Média. São Paulo: Martins Fontes, 1988.

Da Europa Feudal à Renascença. In: ARIES, Philippe; DUBY, George. (Org.). História da vida privada. Trad. Maria Lucia Machado. São Paulo: Companhia das Letras, v. 2, 2002.

DUPONT, Florence. Gramática da alimentação e das refeições romanas. In: FLANDRIN, Jean Louis; MONTANARI, Massimo. (Org.). História da alimentação. Tradução Luciano Vieira Machado; Guilherme J. F. Teixeira. São Paulo: Estação Liberdade, 1998, p. 199-216.

DURKHEIM, Emile. As formas elementares da vida religiosa. Tradução Paulo Neves. São Paulo: Martins Editora, 2003.

ELIAS, Norbert. O processo civilizador. Rio de Janeiro: Jorge Zahar,1994.

FERNANDES, João Azevedo. Selvagens bebedeiras: álcool, embriaguez e contatos culturais no Brasil colonial. 2004. 392 f. Tese (Doutorado em História) - Departamento de História, Universidade Federal Fluminense, Rio de Janeiro, 2004.

FINLEY, Moses I. A economia antiga. Porto: afrontamento, 1986.

Economia e sociedade na Grécia Antiga. São Paulo: Martins Fontes, 1989.

1989. Grécia primitiva: Idade do Bronze e Idade Arcaica. São Paulo: Martins Fontes,

FISCHLER, Claude. Penseé magic et alimentation ajourd'hui. Paris: Les Cahiers de L'Ochat 5, 1996. 
FLANDRIN, Jean-Louis. A humanização das condutas alimentares. In: FLANDRIN, Jean Louis; MONTANARI, Massimo. (Org.). História da alimentação. Tradução Luciano Vieira Machado; Guilherme J. F. Teixeira. São Paulo: Estação Liberdade, 1998, p. 26-25.

Tempero, cozinha e dietética nos séculos XIV, XV e XVI. In: FLANDRIN, Jean Louis; MONTANARI, Massimo. (Org.). História da alimentação. Tradução Luciano Vieira Machado; Guilherme J. F. Teixeira. São Paulo: Estação Liberdade, 1998, p. 478-495.

. A alimentação camponesa na economia de subsistência. In: FLANDRIN, Jean Louis; MONTANARI, Massimo. (Org.). História da alimentação. Tradução Luciano Vieira Machado; Guilherme J. F. Teixeira. São Paulo: Estação Liberdade, 1998, p. 580610.

A distinção pelo gosto. In: ARIÉS, Philippe; DUBY, Georges. (Dir.). História da vida privada: da Renascença ao Século das Luzes. Tradução Hildegard Feist. São Paulo: Companhia das Letras, v. 3, 2009, p. 263-304.

FOSSIER, Robert. Terra. Tradução Vivian Coutinho de Almeida. In: LE GOFF, Jacques; SCHMITT, Jean-Claude. (Org.). Dicionário temático do Ocidente Medieval. São Paulo: Edusc, v. 2, 2006, p. 543-557.

FRANCO JR, Hilário. As utopias medievais. São Paulo: Brasiliense, 1992.

1998. Cocanha: a história de um país imaginário. São Paulo: Companhia das Letras, Cocanha: várias faces de uma utopia. São Paulo: Ateliê Editorial, 1998. . A Eva Barbada. Ensaios e Mitologia Medieval. São Paulo: Edusp, 1996.

O porco, o homem e Deus: a utopia panteísta da Cocanha. Revista USP, n. 50, jun./ago. 2001. 2010. . Os três dedos de Adão: ensaios de mitologia medieval. São Paulo: Edusp, 
FRAZER, James George. The golden bought. New Jersey: Summit Classic Press, 2012.

GÉNICOT, Léopold. Nobreza. Tradução Eliana Magnani. In: LE GOFF, Jacques; SCHMITT, Jean-Claude. (Org.). Dicionário temático do Ocidente Medieval. São Paulo: Edusc, v. 2, 2006, p. 279-291.

GIMBUTAS, Marija. The civilization of the goddess. San Francisco: Harper, 1991.

GOODY, Jack. Cooking, cuisine and class. Cambridge: CUP, 1982.

GRIECO, Allen F. Alimentação e classes sociais no fim da Idade Média e na Renascença. In: FLANDRIN, Jean Louis; MONTANARI, Massimo. (Org.). História da alimentação. Tradução Luciano Vieira Machado; Guilherme J. F. Teixeira. São Paulo: Estação Liberdade, 1998, p. 466-477.

Food for thougth and food for the table. Polity Press, 1989.

GRIMAL, Pierre. A civilização romana. Lisboa: Edições 70, 1988.

GUENÉE, Bernard. Corte. Tradução Daniel Valle Ribeiro. In: LE GOFF, Jacques; SCHMITT, Jean-Claude. (Org.). Dicionário temático do Ocidente Medieval. São Paulo: Edusc, v. 1, 2006, p. 269-282.

GUERREAU, Alain. Feudalismo: um horizonte teórico. Tradução António José Pinto Ribeiro. Lisboa: Edições 70, 1982.

- Caça. Tradução Vivian Coutinho de Almeida. In: LE GOFF, Jacques; SCHMITT, Jean-Claude. (Org.). Dicionário temático do Ocidente Medieval. São Paulo: Edusc, v. 1, 2006, p. 139-151.

GUERREAU-JALABER, Anita. Aliments symboliques et symbolique de la table dans les romans arthuriens. Annales: Historie, Sciences Sociales, 47, n. 3, mai./jun. 1992. EHESS, p. 561-94.

GUICHARD, Pierre. Islã. Tradução José Rivair de Macedo. In: LE GOFF, Jacques; SCHMITT, Jean-Claude. (Org.). Dicionário temático do Ocidente Medieval. São Paulo: Edusc, v. 1, 2006, p. 633-649. 
HALARD, X. La pêche au saumon em Normandie du XIe au XVe siècles. Journal of medieval History, 1983.

HENISCH, Bridget Ann. Fast and feast food. In: Medieval Society. University Park, 1976.

HYMAN, Mary ET Philip. Os livros de cozinha na França entre os séculos XV e XI. In: FLANDRIN, Jean Louis; MONTANARI, Massimo. (Org.). História da alimentação. Tradução Luciano Vieira Machado; Guilherme J. F. Teixeira. São Paulo: Estação Liberdade, 1998, p. 625-639.

HUIZINGA, Johan. O outono da Idade Média. São Paulo: Cosac Naify, 2010.

INGEMARK, Dominic. Glass, alcoholand power in RomanIron Age Scotland: a study of the Roman vesselglass from non-Roman/ native sitesin north Northumberland and Scotland. Doctoral Dissertation. Lund University, 2003.

JOANNÉS, Francis. A função social do banquete nas primeiras civilizações. In: FLANDRIN, Jean Louis; MONTANARI, Massimo. (Org.). História da alimentação. Tradução Luciano Vieira Machado; Guilherme J. F. Teixeira. São Paulo: Estação Liberdade, 1998, p. 54-67.

KANT, Emanuel, Antropologie $d u$ point vue pragmatique. Paris: Librairie Philosophique J. Vrin, 1994.

KERÉNYI, Karl. Dionísio: imagem arquetípica da vida indestrutível. São Paulo: Odysseus, 2002.

KRIEGEL, Maurice. Judeus. Tradução Flavio de Campos. In: LE GOFF, Jacques; SCHMITT, Jean-Claude. (Org.). Dicionário temático do Ocidente Medieval. São Paulo: Edusc, v. 2, 2006, p. 37-57.

LAFORTUNE-MARTEL, Agathe: fête noble em Borgogne au XVe siècle. MontrealParis: Bellarmin-Vrin, 1984.

LAUAND, Luiz J. (Org.). Cultura e educação na Idade Média: textos do século V ao XIII. São Paulo: Martins Fontes, 1998.

LAURIOUX, Bruno. Idade Média à mesa. Tradução Elsa Andringa. Lisboa: publicações Europa-América, 1992. 
. Cozinhas medievais. In: FLANDRIN, Jean Louis; MONTANARI, Massimo. (Org.). História da alimentação. Tradução Luciano Vieira Machado; Guilherme J. F. Teixeira. São Paulo: Estação Liberdade, 1998, p. 447-465.

Le régne de Taillevent: livres et pratiques culinaires a la fin du Moyen Âge. Paris: Publications de La Sorbonne, 1997.

Manger au Moyen Â: pratiques et discours alimentaires em Europe au XIV et XV siècles. Paris: Hachette de Littératures, 2002.

LE GOFF, Jacques. A civilização do Ocidente Medieval. Tradução José Rivair de Macedo. São Paulo: Edusc, 2002.

A bolsa e a vida. Tradução Rogerio Silveira Muoio. São Paulo: Editora Brasiliense, 2004.

Centro/Periferia. Tradução Flavio de Campos. In: LE GOFF, Jacques; SCHMITT, Jean-Claude. (Org.). Dicionário temático do Ocidente Medieval. São Paulo: Edusc, v. 1, 2006, p. 201-207.

Cidade. Tradução. Flavio de Campos. In: LE GOFF, Jacques; SCHMITT, JeanClaude. (Org.). Dicionário temático do Ocidente Medieval. São Paulo: Edusc, v. 1, 2006, p. 219-236.

O apogeu da cidade medieval. Tradução Antônio de Pádua Danesi. São Paulo: Martins Fontes, 1992.

LÉVI-STRAUSS, Claude. Mythologiques I-IV. Paris: Plon, 1971.

LOZINSKI, Grégoire. La Bataille de Caresme et de Charnage, Paris, 1933. Disponível em: $\quad<$ http://www.worldcat.org/title/la-bataille-de-caresme-et-de-charnage-editioncritique-of-the-poem-de-quaresme-et-de-charnage-from-ms-fr-837-in-the-bibliothequenationale-avec-introduction-et-glossaire-par-gregoire-lozinski/oclc/561850603>. Acesso em: 20 nov. 2012.

MALTHUS, Thomas. An essay on the principle of population. London: Penguin, 1985. 
MANTEYER, M. de. Le Menu general de Monsieur le Dauphi, Bullet. De la Soc. D'Études histor., scientif, et littéraires des Hautes-Alpes. 1941.

MAUSS, Marcel; HUBERT, Henri. Sobre o sacrificio. Tradução Paulo Neves. São Paulo: Cosac Naif, 2005.

MAZZINI, Innocenzo. A alimentação e a medicina no mundo antigo. In: FLANDRIN, Jean Louis; MONTANARI, Massimo. (Org.). História da alimentação. Tradução Luciano Vieira Machado; Guilherme J. F. Teixeira. São Paulo: Estação Liberdade, 1998, p. 254-255.

MEHL, Jean-Michel. Jogo. Tradução Flávio de Campos. In: LE GOFF, Jacques; SCHMITT, Jean-Claude. (Org.). Dicionário temático do Ocidente Medieval. São Paulo: Edusc, v. 2, 2006, p. 25-36.

MILANI, Lara Borriero. Para compreender Le Viandier: do estudo do livro medieval de receitas à elaboração de um glossário verbal culinário. 2010. 203 f. Dissertação (Mestrado em Estudos Linguísticos, Literários e tradutológicos em Francês) - Faculdade de Filosofia, Letras e Ciências Humanas, Universidade de São Paulo, São Paulo, 2010.

MENNEL, Stephen. All manners of food. Illinois: University of Illinois Press, 1996.

MINTZ, Sidney W. Comida e antropologia: uma breve revisão. São Paulo: Revista Brasileira de Ciências Sociais, 2008.

MONGELLI, Lênia Marcia de Medeiros. O país da Cocanha: a imagem de uma utopia medieval. Jornal da Tarde, São Paulo, 07 nov. 1998, Caderno de Sábado, p. 3.

MONTESQUIEU, Charles Louis de Secondart. O espírito das leis. Brasília: UNB, 1982.

MONTANARI, Massimo. Estruturas de produção e sistemas alimentares. In: FLANDRIN, Jean Louis; MONTANARI, Massimo. (Org.). História da alimentação. Tradução Luciano Vieira Machado; Guilherme J. F. Teixeira. São Paulo: Estação Liberdade, 1998, p. 282-291.

Modelos alimentares e identidades culturais. In: FLANDRIN, Jean Louis; MONTANARI, Massimo. (Org.). História da alimentação. Tradução Luciano Vieira Machado; Guilherme J. F. Teixeira. São Paulo: Estação Liberdade, 1998, p. 312-317. 
Os camponeses, os guerreiros e os sacerdotes: imagem da sociedade e estilos de alimentação. In: FLANDRIN, Jean Louis; MONTANARI, Massimo. (Org.). História da alimentação. Tradução Luciano Vieira Machado; Guilherme J. F. Teixeira. São Paulo: Estação Liberdade, 1998, p. 292-309.

Romanos, bárbaros e cristãos: na aurora da cultura alimentar europeia. In: FLANDRIN, Jean Louis; MONTANARI, Massimo. (Org.). História da alimentação. Tradução Luciano Vieira Machado; Guilherme J. F. Teixeira. São Paulo: Estação Liberdade, 1998, p. 178-281.

. Rumo a um novo equilíbrio alimentar. In: FLANDRIN, Jean Louis; MONTANARI, Massimo. (Org.). História da alimentação. Tradução Luciano Vieira Machado; Guilherme J. F. Teixeira. São Paulo: Estação Liberdade, 1998, p. 382-386.

Alimentação. Tradução Vivian Coutinho de Almeida. In: LE GOFF, Jacques; SCHMITT, Jean-Claude. (Org.). Dicionário temático do Ocidente Medieval. São Paulo: Edusc, v. 1, 2006, p. 35-45.

A fome e a abundância: história da alimentação na Europa. Tradução Andréa Doré. São Paulo: Edusc, 2003. 2008 .

Comida como cultura. Tradução Letícia Martins de Andrade. São Paulo: Senac, . (Org.). O mundo na cozinha: história, identidade, trocas. Tradução Valéria Pereira da Silva. São Paulo: Estação Liberdade/Senac, 2009.

MOMIGLIANO, Arnaldo. A interação cultural das civilizações grega, romana, céltica e persa. Rio de Janeiro: Jorge Zahar, 1991.

MORTON, Arthur L. The English Utopia. Londres: Lawrence and Wishart, 1952.

NASH, Gary B. Red, white and black: the people of early North America. New Jersey: Prentice Hall, 1992.

NEVEUX, Hugues. L'Histoire de la France rurale. Paris: Seuil, 1975.

NIETZSCHE, Friedrich. Crepuscule dês idoles. Paris: Gallimard, 1974. 
OUÉDRAOGO, Arouna. De la secte religieuse à l'utopie philanthropique. Annales HSS, n. 4, juillet-août, 2000.

PANTEL, Pauline. As refeições gregas: um ritual cívico. In: FLANDRIN, Jean Louis; MONTANARI, Massimo. (Org.). História da alimentação. Tradução Luciano Vieira Machado; Guilherme J. F. Teixeira. São Paulo: Estação Liberdade, 1998, p. 155-169.

PARIENTÉ, Henriette; TERNANT, Geneviève. Histoire de La cuisine française. Paris: Édidions de La Martinière, 1994.

PASTOREAU, Michel. Símbolo. Tradução Lênia Márcia Mongelli. In: LE GOFF, Jacques; SCHMITT, Jean-Claude. (Org.). Dicionário temático do Ocidente Medieval. São Paulo: Edusc, v. 2, 2006, p. 495-510.

PAYEN, Jean-Charles. Litterature française: le Moyen Âge. Paris: Arthaud, 1990.

PIGGOTT, Stuart. A Europa Antiga: do início da agricultura à Antiguidade Clássica. Lisboa: Caloust Gulbekian, 1981.

PIPONNIER, Françoise. Do fogo à mesa: a arqueologia do equipamento culinário no fim da Idade Média. In: FLANDRIN, Jean Louis; MONTANARI, Massimo. (Org.). História da alimentação. Tradução Luciano Vieira Machado; Guilherme J. F. Teixeira. São Paulo: Estação Liberdade, 1998, p. 509-520.

Cotidiano. Tradução Mario Jorge da Motta Bastos. In: LE GOFF, Jacques; SCHMITT, Jean-Claude. (Org.). Dicionário temático do Ocidente Medieval. São Paulo: Edusc, v. 1, 2006, p. 283-300.

POUCHELLE, Marie C. Medicina. Tradução Mario Jorge da Motta Bastos. In: LE GOFF, Jacques; SCHMITT, Jean-Claude. (Org.). Dicionário temático do Ocidente Medieval. São Paulo: Edusc, v. 1, 2006, p. 151-166.

RABELAIS, François. O terceiro livro dos fatos e ditos heroicos do bom Pantagruel. Tradução Élide Valarini Oliver. Cotia: Ateliê Editorial, 2006.

RESLER, Michael. Erec by Hartmann von Aue: translation, introduction, commentary. Philadelphia: University of Pennsylvania Press, 2004.

REVEL, Jean-François. Um banquete de palavras: uma história da sensibilidade gastronômica. Tradução Paulo Neves. São Paulo: Companhia das Letras, 1996. 
RIERA-MELIS, Antoni. Sociedade feudal e alimentação (séculos XII e XIII). In: FLANDRIN, Jean Louis; MONTANARI, Massimo. (Org.). História da alimentação. Tradução Luciano Vieira Machado; Guilherme J. F. Teixeira. São Paulo: Estação Liberdade, 1998, p. 387-408.

ROMAGNOLI, Daniela F. Guarda no sii vilan: as boas maneiras à mesa. In: FLANDRIN, Jean Louis; MONTANARI, Massimo. (Org.). História da alimentação. Tradução Luciano Vieira Machado; Guilherme J. F. Teixeira. São Paulo: Estação Liberdade, 1998, p. 496-508.

ROMERO, José Luis. Crise e ordem no mundo feudoburguês. Tradução Zilda H. S. Silva. São Paulo: Palíndromo, 2005.

ROUCHE, Michel. Le repas de fête à l'epoque carolingienne: essai sur quelques types derations alimentaires, em Manger et Boire. t. 1, 1973.

ROUSSEAU, Jean Jacques. Discurso sobre a origem e os fundamentos da desigualdade entre os homens. São Paulo: Editora Ática, 1989.

ROZIN, Paul. Food is fundamental, fun, frightening, and far-reaching. Social Research 66, 1998, p. 9-30.

RUDGLEY, Richard. Essential substances: a cultural history of intoxicants in society. New York: Kodansha, 1995.

SASSATELLI, Giuseppe. A alimentação dos etruscos. In: FLANDRIN, Jean Louis; MONTANARI, Massimo. (Org.). História da alimentação. Tradução Luciano Vieira Machado; Guilherme J. F. Teixeira. São Paulo: Estação Liberdade, 1998, p. 186-198.

SCHMITT, Jean-Claude. Corpo e Alma. Tradução Eliana Magnani. In: LE GOFF, Jacques; SCHMITT, Jean-Claude. (Org.). Dicionário temático do Ocidente Medieval. São Paulo: Edusc, v. 2, 2006, p. 253-267.

Ritos. Tradução Eliana Magnani. In: LE GOFF, Jacques; SCHMITT, JeanClaude. (Org.). Dicionário temático do Ocidente Medieval. São Paulo: Edusc, v. 2, 2006, p. 415-430.

SCULLY, Terence. The art of Cookery in the Middle Age. Woodbridge: The Boydell Press, 1995. 
Du fait de cuisine par Maistre Chiquart, 1420. Vallesia, 1985.

SHERRAT, Andrew. Envisioning global change: a long-term perspective. Denemark, 2000 .

SERGENT, Bernard. Os indo-europeus: gênese e expansão de uma cultura. In: LÉVÊQUE, Pierre. (Dir.). As primeiras civilizações. Lisboa: Edições 70, 1990. p. 9144.

SOLER, Jean. As razões da Bíblia: regras alimentares hebraicas. In: FLANDRIN, Jean Louis; MONTANARI, Massimo. (Org.). História da alimentação. Tradução Luciano Vieira Machado; Guilherme J. F. Teixeira. São Paulo: Estação Liberdade, 1998, p 8091.

SMIL, Vaclav. Feeding the world. Cambridge: MIT Press, 2000.

SMITH, Willian Robertson. The Religion of the Semites. New Jersey: Transaction Publishers, 2002

STOUFF, Louis. Ravitaillement et alimentation em Provence aux XIV e XVe siècles. Paris: Mouton, 1970.

TALEB, Nassim Nicholas. A lógica do cisne negro: o impacto do altamente improvável. Tradução Marcelo Schild. Rio de Janeiro: Best Seller, 2007.

TEUTEBERG. European food history, London: Leicester University Press, 1992.

TREFZER, Rudolf. Clássicos da literatura culinária: os mais importantes livros da história da gastronomia. Tradução Marcelo Rondinelli. São Paulo: Senac, 2009.

TYLOR, Edward Burnett. Primitive culture. Charleston: Nabu Press, 2010.

VARAZZE, Jacopo de. Legenda Áurea. Tradução Hilário Franco Júnior. São Paulo: Companhia das Letras, 2003.

VERGER, Jacques. Homens e saber na Idade Média. Tradução Carlota Boto. Bauru: Edusc, 1999. 
VETTA, Massimo. A cultura do symposium. In: FLANDRIN, Jean Louis; MONTANARI, Massimo. (Org.). História da alimentação. Tradução Luciano Vieira Machado; Guilherme J. F. Teixeira. São Paulo: Estação Liberdade, 1998, p. 170-185.

VEYNE, Paul. O Império Romano. In: ARIES, Philippe; DUBY, George. (Org.). Do Império Romano ao ano mil. Tradução Maria Lucia Machado. São Paulo: Companhia das Letras, v. 1, 2002.

ZAREMSKA, Hanna. Marginais. Tradução Flavio de Campos. In: LE GOFF, Jacques; SCHMITT, Jean-Claude. (Org.). Dicionário temático do Ocidente Medieval. São Paulo: Edusc, v. 2, 2006, p. 121-136. 